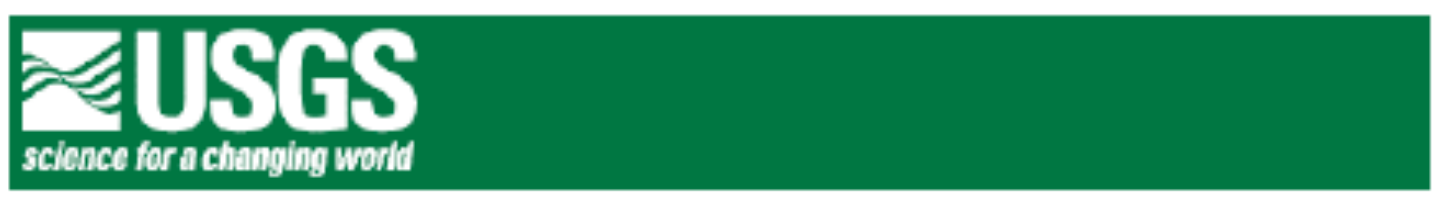

\title{
Pocomoke Sound Sedimentary and Ecosystem History
}

Edited by Thomas M. Cronin

October, 2004

OFR-2004-1350

U.S. Department of Interior

U.S. Geological Survey

NOTE: Report not reviewed for consistency and standardization by USGS 


\section{Pocomoke Sound Sedimentary and Ecosystem History}

Table of Contents

Chapter 1. Introduction to Pocomoke Sound Sediments and Hydrography....

By T.M. Cronin, D. A. Willard, W. Newell, C. Holmes, J. Halka, M. Robertson

Chapter 2. Sediment and chemical flux history in the Pocomoke Sound as defined by short lived isotopic analysis

By C. W. Holmes and M. Marot

Chapter 3. Sediment Transport in Pocomoke Sound, Maryland Inferred from Microfossils in Surface Sediments

By D. A. Willard, T. M. Cronin, C. E. Bernhardt, J. Damon

Chapter 4. Stratigraphy and Age of Pocomoke Sound Sediments

By T. M. Cronin, M. Robertson, D. Willard, J. Halka

Chapter 5. Temporal Trends in Benthic Microfossils in Pocomoke Sound: Implications for Water Quality...

By T. M. Cronin and A. Edwards

Chapter 6. Stable Isotopes of Foraminifera from Pocomoke Sound..................... By T. M. Cronin, R. Thunell, C. Saenger, R. R. Seal, II, C. Vann

Chapter 7. Pollen Stratigraphy and Land-Use Change, Pocomoke Sound....... By D. A. Willard, C. E. Bernhardt 
Summary of Results: Pocomoke Sound Sediment and Sediment Processes

Transport of sediment from coastal marshes. Analyses of pollen and foraminifera from surface sediments in Pocomoke Sound suggest that neither the upstream forested wetlands nor coastal marshes bordering the sound have contributed appreciably to particulate matter in the 10- to 1000-micron size range that is currently being deposited in the sound.

Sediment processes derived from short-lived isotope. Analyses of beryllium-7, cesium137 and lead-210 and redox sensitive elements from Pocomoke sediments showed that there has been a significant increase in anthropogenic elements since the late 1940's when the Delmarva Peninsula became more accessible from the Baltimore-Washington region. Cesium-137 was found to be a useful tool to determine changes in sedimentation within the system. Three major stages of sedimentation occurred. Before 1950, the system was equilibrium with the agriculture activity in the watershed, whereas urbanization and agricultural activity changes during and immediately preceding World War II resulted in increased sediment flux. Around 1970, the sediment flux diminished and there was an apparent increase in bank erosion sediment to the deeper parts of the system.

Rates of sediment deposition. Radiocarbon, lead-210, and pollen dating of sediment cores from Pocomoke Sound indicate relatively continuous deposition of fine-grained sediments in the main Pocomoke channel at $>\sim 7 \mathrm{~m}$ water depths. Mean sediment accumulation rates during the past few centuries were relatively high $\left(>1 \mathrm{~cm} \mathrm{yr}^{-1}\right)$. The ages of coarser-grained sediments (sands) blanketing the shallow ( $<\sim 7 \mathrm{~m}$ water depth) flanks of Pocomoke Sound are not well constrained but were probably deposited discontinuously.

Impacts of land-use on benthic biota. The Pocomoke Sound paleoecological record shows that in the 1940-50s and again in the 1970-80s, the sound experienced unprecedented changes in the benthic assemblages of both ostracodes and foraminifera 
that can be attributed to degradation in water quality. These changes represent perturbations to the natural variability in faunal assemblages, which are normally driven by climatically influenced changes in salinity regimes. Changes in $20^{\text {th }}$ century benthic communities were characterized by the rise to dominance of facultative anaerobic taxa tolerant of hypoxia and detrital-feeding species, reflecting increased influx of organic matter, and perhaps greater turbidity. Results support the hypothesis of Orth et al. (2002) and Orth and Moore (1983) that unprecedented changes to the bay ecosystem affected submerged aquatic vegetation in the Tangiers-Pocomoke region prior to large-scale monitoring began in the 1970s and 80s. Comparison of Pocomoke paleoecological record with those from the mainstem bay indicate that environmental degradation during the $20^{\text {th }}$ century was nearly synchronous bay-wide within the limits of sediment core chronology (10-20 years).

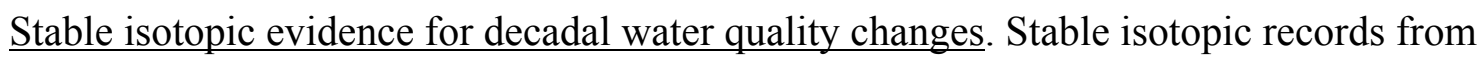
benthic foraminifera in Pocomoke Sound sediment cores, especially oxygen isotopes, document regional decadal and centennial climate processes which influence salinity and water quality over the past few centuries. These results provide indirect evidence for discharge-driven changes in freshwater and presumably river-borne sediment from the watershed to the sound. They are consistent with studies in the mainstem indicating the important influence of climatic and hydrological processes on water quality.

\section{Pollen evidence for high sedimentation and vegetation change during colonial land} clearance. Pollen assemblages from sediment cores in Pocomoke Sound document high sedimentation rates $\left(0.7->4.0 \mathrm{~cm} \mathrm{yr}^{-1}\right)$ at most sites throughout the Sound in postColonial time. These results confirm those from other regions of the bay that landclearance increased the flux of river-borne sediment to certain regions of the bay. Records from one nearshore site indicate that cypress logging in the early $20^{\text {th }}$ century completely changed forest composition and may have increased shoreline/wetland erosion rates to the sound. Reforestation, beginning in the 1940 's, is documented consistently by doubling of sweetgum pollen, which provides a new biostratigraphic marker in Chesapeake Bay sediments. 


\section{Chapter 1. Introduction to Pocomoke Sound Sediments}

T.M. Cronin*, D. A. Willard*, W. Newell*, C. Holmes**, J. Halka\#, M. Robertson*

* U.S. Geological Survey, Reston, Virginia 20192; ** U.S. Geological Survey, St.

Petersburg, Florida, 33701; \# Maryland Geological Survey, Baltimore, Maryland 21218

\section{Introduction}

Sediment carried by rivers and eroded from shorelines is a major environmental problem in Chesapeake Bay and its tributaries due to its direct effect on water clarity and indirect effect on living resources, notably submerged aquatic vegetation (SAV) (Orth and Moore, 1983; Batiuk and others, 2000). Although there have been numerous studies of sedimentary processes in Chesapeake Bay and surrounding regions during the past 50 years, there is still considerable uncertainty about the relative contributions of river-borne and shoreline sources of sediment, the contribution of oceanic-source sediment in the southern bay, and the impact of land-use changes on the sediment budgets (Langland and Cronin, 2003). An improved understanding of patterns of sediment transport in the bay is particularly important for future management decisions about remedial strategies in various tributaries and watersheds, and for improving watershed modeling efforts to simulate the effect of best management practices on sediment flux.

The present study was designed to determine patterns of sedimentation and sediment-related processes in Pocomoke Sound using a variety of geological methods. Pocomoke Sound is a large body of water located in the southeastern part of Chesapeake Bay (Figure 1.1) with several characteristics suitable for the study of temporal and spatial sedimentary patterns. Its main channel ( 24 m water depth) is separated from the deep channel of the bay's mainstem and the deep channel in Tangiers Sound, located to the north, by a relatively shallow ( $<2$ to $12 \mathrm{~m}$ ) region in the vicinity of Watts Island. The shallow areas in the Pocomoke and Tangiers Sound region are critical habitats for SAV, however both Tangiers and Pocomoke Sounds experienced declines in SAV acreage between 1992 and 1999 (Orth and others, 2002). More generally, it is generally believed 
that significant declines in SAV during the $20^{\text {th }}$ century has been caused by land-use changes in the bay's watershed. To more fully understand the relationship between SAV, water clarity and sediment processes, a long-term perspective regarding the sources of sediment in Pocomoke Sound is needed. This chapter provides a brief overview of previous studies, methods used, and modern hydrography for Pocomoke Sound.

\section{Sediment Sources}

The Pocomoke Sound channel is the site of a thick (10-25 m) sequence of finegrained Holocene sediments deposited over the past 8,000 years, which preserves a record of sedimentation both before and after colonial land clearance and under different climatic and hydrological extremes. Sediment consists of particulate material entering Pocomoke Sound from four potential sources: river-borne sediment from the Pocomoke River, sediment eroded from shorelines (mainly tidal marsh sediments), sediment entering the sound from the south where the Pocomoke Sound channel extends to near the mouth of the bay (see Langland and others, 2003), and biogenic particulate material formed by phytoplankton and other organisms living in the sound. The first three sources of sediment are the main focus of this report. Biogenic material produced in the water column by organisms is not directly considered in the current study, however some of our results regarding climatically-driven changes in Pocomoke Sound salinity are pertinent to the inflow of nutrients and primary productivity over decadal and centennial timescales.

The amount of river-borne sediment entering the sound will be a function mainly of the watershed topography, geology, land cover, climatological and hydrological characteristics. The Pocomoke River basin consists of an $813 \mathrm{mi}^{2}$ watershed, which is relatively small compared to other major tributaries to Chesapeake Bay. The Pocomoke watershed is currently comprised of $48 \%$ forested, $34 \%$ agriculture, $14 \%$ wetlands, and $4 \%$ urban land-use. It is comprised of a relatively low-lying coastal plain and, in contrast to watersheds of bay tributaries on the western side of the bay, does not drain parts of the Piedmont and Appalachian physiographic provinces. The Pocomoke River, which enters Pocomoke Sound in its the northeastern corner, is also a relatively small river in terms of mean annual discharge. In these ways, the Pocomoke system represents a distinct contrast with the larger tidal tributaries located on the west side of the mainstem 
bay such as the Potomac, James, Rappahannock, and Patuxent Rivers, which are subestuaries characterized by strong vertical salinity gradients and turbidity maximum zones like those in the mainstem bay.

Shoreline erosion can contribute as much as $50 \%$ of the total sediment load in some areas of Chesapeake Bay, depending on coastal characteristics and other factors (Miller, 1987). Like much of the eastern shore of Chesapeake Bay, low-lying tidal marshes form the margins of much of Pocomoke Sound, in contrast to parts of the western side of Chesapeake Bay, where coastal seacliffs, dunes and other features occur. Erosion of marsh habitats by tides, waves, storm surges and rising sea level could, in theory, contribute a large proportion of sediment to the Pocomoke Sound.

A large flux of sediment enters Chesapeake Bay at its mouth originating from the continental shelf (Ludwick, 1974; Byrne and others, 1983; Colman and Hobbs, 1988). Although much of this sediment is coarse-grained (sand) and there is evidence for both bayward and seaward transport, it is unclear how much net fine-grained (clays and silts) sediment comes from oceanic sources or how far north it is transported. In their comprehensive survey of surficial sediments in the Virginia portion of Chesapeake Bay, Byrne and others (1983) concluded that significant amounts of coarse-grained and probably fine-grained sediments derived from the continental shelf were advected northward from the baymouth region. Moreover, oceanographic studies of drifters (Norcross and Stanley, 1967) and bottom currents (Bumpas, 1973; Beardsley and Boicourt, 1981) indicate strong nearshore bottom flow into Chesapeake Bay. Therefore, Pocomoke Sound must be considered a potential sink for ocean sediments carried northward from the baymouth, as well as a catchment area for river-borne and shoreline sediments from the Pocomoke Sound area itself.

In summary, the current study is designed to provide a basic understanding of sediment deposition in this unique region of the greater Chesapeake area through the analysis of various micropaleontological, geochemical, and geochronological indicators found in surficial sediments and sediment cores collected in Pocomoke Sound.

\section{Previous Studies of Pocomoke Sediments}


Previous studies of the Pocomoke Sound applied sedimentological, geological, and geophysical (seismic) methods to determine the basic characteristics and distribution of the sediments deposited in this region. As part of a comprehensive analysis of surface sediment characteristics in the Virginia portion of Chesapeake Bay, Byrne and others (1983) found that the surface sediments in Pocomoke Sound generally conformed to patterns found through the mainstem (Kerhin and others, 1988); that is, courser grained sediment (mostly sand sized) blankets the shallower regions (< 6-10 $\mathrm{m}$ water depth) and fine-grained sediment (clays and silts) covers the deeper regions in the channels. Hobbs, (1983, see also Byrne and others, 1983 for review of previous studies) analyzed the carbon and sulfur content of Chesapeake Bay surficial sediments, including some samples from the Pocomoke region. Hobbs (1983) concluded that finer grained sediments in Pocomoke Sound contain 1.5-2\% carbon, and generally have higher proportions of carbon than course-grained sediments. The sulfur content in Pocomoke sediments was about $0.2-0.4 \%$.

Byrne and others (1983, see also Byrne and Anderson 1977) also used $19^{\text {th }}$ and $20^{\text {th }}$ century (1850 versus 1950 ) bathymetric surveys, short sediment cores, and coastal geomorphological and geological data to construct a sediment budget for the southern part of Chesapeake Bay. Although the focus of their study was the mainstem of Chesapeake Bay, their observation that shoreline-derived sediment is highest in the vicinity of headlands and lowest near river mouths and low-lying marsh coastlines, suggests that the marsh-dominated Pocomoke coastline is not a major sediment source for Pocomoke Sound.

Colman and Hobbs (1988) used seismic profiles to delineate the positions of the Quaternary paleochannels in southern Chesapeake Bay and parts of Pocomoke Sound formed during glacial periods of low global sea level. They showed that the thickness of Holocene overlying the Cape Charles erosion surface was between 10 and $>25 \mathrm{~m}$ thick, similar to that in the mainstem of the bay. These geophysical data were used in the present study to select sites for sediment coring and analysis.

The lower portion of Pocomoke Sound was also studied by Hobbs (1988) who examined the prospect of mining fossil oyster shells near the mouth of the sound. Hobbs ran shallow seismic-reflection profile surveys through portions of Pocomoke and 
Tangiers Sounds under the assumption that oysters had likely grown along the walls of the Pocomoke channel at times when sea level was lower. Based on eleven vibracores ranging from 5.5 to $12 \mathrm{~m}$ of sediment recovery, Hobbs (1988) concluded that the oyster deposit near Parkers Rock in Pocomoke Sound is a low density, widely distributed, nearsurface deposit with approximately $178,450 \mathrm{~m}^{3}$ of shell within the larger area of $1,003,200 \mathrm{~m}^{2}$.

\section{Materials and Methods}

The current study involves several approaches to the study of Pocomoke Sound Study. The objectives and methods of each approach are briefly summarized here and discussed in more detail with the results in later chapters. Lithological, chronological, micropaleontological and X-raadiograph data can be viewed and obtained from the website http://geology.er.usgs.gov/eespteam/atlantic/index.htm.

Sediment coring. Sediment cores were taken aboard the vessel R/V Kerhin, May 15-16, 2001, and September, 17-19, 2001. Piston and gravity corers were collected from shallow-deep-shallow transects in the southern, central and northern regions of the sound. Sediment recovery ranged from 73 to $200 \mathrm{~cm}$ in May 2001 and longer cores $(500 \mathrm{~cm})$ were taken at sites PC-2B and PC-6B in September 2001 (Table 1.1). All sites were located using Differential Global Positioning System (DGPS), and cores were stored in $6.7 \mathrm{~cm}$ diameter cellulose acetate butyrate $(\mathrm{CAB})$ core liners.

Twenty-eight surficial sediment samples were also collected along transects in Pocomoke Sound (Table 1.2), and replicates of these were collected during the May and September, 2001 cruises for the purpose of evaluating the sources of modern Pocomoke Sound sediments. The surficial sediments were collected with a Van Veen sampler, and subsampled with 4.25 -inch diameter core liners, before sectioning the upper $4 \mathrm{~cm}$ into 1cm intervals. During May 14-16, 2001, a smaller support boat collected additional surface samples in the shallow waters of Pocomoke Sound that could not be reached with the R/V Kerhin. This sampling involved the use of a Ponar grab sampler that homogenized the upper few centimeters of sediment. 
$X$-radiograph analysis. X-radiographs of bay sediments provide valuable information on sedimentary structures (burrowing, laminations etc), grain size, the occurrence of gas, and other properties that are important in the interpretation of the chronology for the core and microfossil and geochemical patterns. Sediment cores were x-radiographed in their liners at the Maryland Geological Survey (MGS) using a Xerox 125 xeroradiograph processor. X-radiographs assist in delineating small-scale internal structures in the cores such as clam burrows, shells or gas voids. On the negative film, denser material, such as a shell, appears lighter whereas the less dense material, such as a gas void or burrow, appears darker. After X-radiography, sediment was extruded from the core liner, split along the axis, digitally photographed, examined and described. The physical characteristics and sedimentary structures were logged, and the core descriptions emphasized qualitative grain size. Visible shells were immediately sampled from selected horizons for radiocarbon dating.

Radiocarbon and lead-210 dating. Establishing an accurate age-model for the deposition of Pocomoke sediments is essential for interpreting temporal patterns of sedimentation. Three methods were used to date Holocene sediments from the cores: radiocarbon $\left({ }^{14} \mathrm{C}\right)$, lead-210 $\left({ }^{210} \mathrm{~Pb}\right)$ radiometric dating, and pollen stratigraphy (see below). Radiocarbon ages on shells of estuarine mollusks (Cronin and others, 2000; Colman and others, 2002) can provide ages on Holocene sediments older than about 400500 years. Lead-210 dating was used in one core to establish the rate of sedimentation over the past century and with pollen stratigraphy, especially the relative proportion of Ambrosia (ragweed) pollen, it was used for chronology over the past 200 years. It was also possible to correlate cores from within Pocomoke Sound and to those from other regions of the bay using benthic foraminifers and ostracode faunal assemblages and stable isotopic ratios (Cronin and others, 2000; Karlsen and others, 2000; Cronin and Vann, 2003). The results of the various dating and correlation methods are discussed in the following chapters. 
Microfossil Processing Following X-radiography, cores were sampled for calcareous microfossil and pollen analysis to reconstruct the region's ecological history. To analyze fossilized shells of calcareous organisms (benthic foraminifera and ostracodes) as indicators of paleoecological history, sediment samples taken every 2 to 10 -cms were washed through a $63-\mu \mathrm{m}$ sieve. The remaining sand-sized portion was dried at $\sim 52^{\circ} \mathrm{C}$ in a convection oven for twenty-four hours. After 24 hours, the sediment was stored in $8 \mathrm{ml}$ clear glass vials, and the portion of sediment $>150 \mu \mathrm{m} \mathrm{s}$ was picked for foraminifera and ostracodes under a microscope using a fine brush (see Karlsen and others, 2000 for details).

Pollen was isolated from sediments at $10-\mathrm{cm}$ intervals using standard palynological preparation techniques (Traverse, 1988; Willard and Korejwo, 2000). One tablet of Lycopodium spores was added to each sample (5-7 g dry weight) to calculate its pollen concentration. Samples were processed with HCL and HF to remove carbonates and silicates respectively, acetolyzed (1 part sulfuric acid: 9 parts acetic anhydride) in a boiling water bath for 10 minutes, neutralized, and treated with $10 \% \mathrm{KOH}$ for 10 minutes in a $70^{\circ} \mathrm{C}$ water bath. After neutralization, residues were sieved with $149 \mu \mathrm{m}$ and $10 \mu \mathrm{m}$ nylon meshes to remove the coarse and clay fractions, respectively. When necessary, samples were swirled in a watch glass to remove mineral matter. After staining with Bismarck Brown, palynomorph residues were mounted on microscope slides in glycerin jelly. At least 300 pollen grains and 300 dinocysts were counted from each sample to determine percent abundance and concentration of palynomorphs.

Beryllium-7 sampling. The temporal and spatial distribution of berylium-7 $\left({ }^{7} \mathrm{Be}\right)$ can be used to identify sites of recent deposition and short-term variability in sediment delivery and deposition rates in Pocomoke Sound. ${ }^{7} \mathrm{Be}$ is formed in the atmosphere by the interaction of cosmic rays and nitrogen and has a very short half-life of 53 days. This reactive element adheres to sediment immediately; thus, its presence in the sediment is a useful indication that the sediment was in contact with the atmosphere during the previous few months and indicates a recent influx of new material or resuspension of existing sediments. The spatial distribution of ${ }^{7} \mathrm{Be}$ in the surface sediments of Pocomoke 
Sound was analyzed for samples taken during cruises in May and September, 2001 (see Chapter 2).

\section{Hydrography of Pocomoke Sound}

Hydrographic conditions of Pocomoke Sound have been monitored at the Chesapeake Bay Program's (CBP) monitoring stations EE3.3 and EE3.4 since 1984 (Figure 1.1) and are available at the CBP Chesapeake Information Monitoring System (CIMS) website (http://www.chesapeakebay.net/cims/). CBP data were used to examine the characteristics of the hydrography of the sound, including its levels of total suspended sediments. These stations monitor only a small region in the sound and only provide data to water depths of 7 and $8 \mathrm{~m}$, and therefore a complete analysis of the spatial and temporal variability in Pocomoke Sound physical parameters and water quality is not available. Nonetheless, they provide a long-term (20 year) record of conditions that can be compared to other regions of the bay.

Figure 1.2 illustrates the mean annual values for water temperature, salinity, and surface dissolved oxygen at CBP station EE3.3 for the period of record. The figure shows a typical annual temperature cycle from $\sim 5$ to $>25^{\circ} \mathrm{C}$, and a salinity cycle reflecting lowest salinities during the spring runoff ( $\sim 15 \mathrm{ppt})$ and highest salinities during the fall ( $\sim 19 \mathrm{ppt})$. Although monitoring data are not available from most of the sound, we expect lower salinity closer to the mouth of the Pocomoke River and higher salinity nearer the southern end of the sound, reflecting the mixing of fresh and marine waters.

Figure 1.3 shows a vertical profile of temperature, salinity and dissolved oxygen from CBP stations EE3.3 and EE3.4 from spring and fall, 2000. They illustrate relatively small differences in temperature, salinity, and dissolved oxygen within the upper 2.5 to $4.0 \mathrm{~m}$ of water at each site. Monitoring data below $4 \mathrm{~m}$ water depth is not available.

Figure 1.4 compares the seasonal, interannual, and depth related (2-4 m versus 0.5 m) variability in total suspended solids (TSS) at Pocomoke Sound station EE3.3 to the same data from a mainstem bay station (CB4.4). One sees that TSS in Pocomoke exhibits a large amount of variability with generally (but not exclusively) the highest values occurring during spring months. The patterns for shallow water depths (2-4 m) and surface zones $(0.5 \mathrm{~m})$ are generally similar ranging from $10-40 \mathrm{mg} \mathrm{L}^{-1}$, reflecting 
their proximity to one another. In contrast, there is a strong contrast between surface $(0.5$ $\mathrm{m})$ and deep bottom (24.5-31 m) TSS patterns at mainstem station CB4.4. It is notable that the bottom TSS levels at station CB4.4 are typical of other deep channel sites where strong wintertime pulses of TSS exceeding $80 \mathrm{mg} \mathrm{L}^{-1}$ rise above a baseline level of $<10$ $\mathrm{mg} \mathrm{L}^{-1}$.

Seasonal depletion of dissolved oxygen (DO) is a major environmental problem in Chesapeake Bay and DO is monitored monthly or bimonthly at many stations around the bay. Graphical depiction of spatial and temporal patterns of hypoxia available from the Chesapeake Bay Program show dissolved oxygen in the southern part of Pocomoke Sound can be mildly hypoxic (1-3 $\mathrm{mg} \mathrm{L}^{-1}$ ) during relatively wet years with high river runoff, although most years Pocomoke Sound is well oxygenated. However, monitoring sites in Pocomoke Sound are sparse compared to the rest of the mainstem bay, which experiences complete hypoxia and anoxia during many years.

\section{References}

Batiuk, R.A., Bergstrom, P., Kemp, M., Koch, E., Murray, L., Stevenson, J.C., Bartleson, R., Carter, V., Rybicki, N.B., Landwehr, J.M., Gallegos, C., Karrh, L., Naylor, M., Wilcox, D., Moore, K.A., Ailstock, S., Teichberg, M., 2000, Chesapeake Bay submerged aquatic vegetation water quality and habitat-based requirements and restoration targets: a second technical synthesis: Chesapeake Bay Program, USEPA 231p.

Beardsley, R. C., and Boicourt, W. C. 1981, On estuarine shelf and continental-shelf circulation in the middle Atlantic bight, in Warren, B. A., and Wunsch, C., eds., Evolution of Physical Oceanography, Scientific Surveys in Honor of Henry Stommel: Cambridge, Massachusetts, the MIT Press, p. 198-233.

Bumpas, D. F., 1973, A description of the circulation on the continental shelf of the east coast of the United States: Progress in Oceanography, v. 6, p. 111-157.

Byrne, R. J., and Anderson, G. L., 1977, Shoreline erosion in tidewater Virginia: Special Report in Marine Science and Ocean Engineering no. 111, Virginia Institute of Marine Science, 102 p. 
Byrne, R. J., Hobbs, C. H., III, and Carron, M. J., 1983. Baseline sediment characteristics and sedimentation patterns on the Virginia portion of the Chesapeake Bay: U.S. Geological Survey Report PB83 224899, 155 p.

Colman, S. M., and Hobbs, C. H., III, 1988, Maps showing Quaternary geology of the northern Virginia part of the Chesapeake Bay: U.S. Geological Survey 1:125,000 map, MF-1948-B.

Colman S.M., Baucom P.C., Bratton J.F., Cronin T.M., McGeehin J.P., Willard D., Zimmerman A.R., and Vogt P.R., 2002, Radiocarbon dating, chronologic framework, and changes in accumulation rates of Holocene estuarine sediments from Chesapeake Bay: Quaternary Research, v. 57, p. 58-70.

Cronin, T. M., Willard, D. A., Kerhin, R. T., Karlsen, A. W., Holmes, C. W., Ishman, S, Verardo, S., McGeehin, J., Zimmerman, A., 2000, Climatic variability over the last millennium from the Chesapeake Bay sedimentary record: Geology, v. 28, p. 3-6.

Cronin, T. M., and Vann, C. D. 2003, the sedimentary record of climatic and anthropogenic influence on the Patuxent Estuary and Chesapeake Bay ecosystems: Estuaries, v. 26 (2A), p. 196-209.

Hobbs, C. H., III, 1983, Organic carbon and sulfur in the sediments of the Virginia Chesapeake Bay: Journal of Sedimentary Petrology, v. 53, p. 383-393.

Hobbs, C. H. III, 1988, Prospecting for fossil oyster shell in Chesapeake Bay: Marine Mining, v. 7, p. 199-209.

Kerhin , R.T., Halka, J.P., Wells, D.V., Hennessee, E.L., Blakeslee, P.J., Zoltan, N., and Cuthbertson, R.H., 1988, The surficial sediments of Chesapeake Bay ,Maryland: Physical characteristics and sediment budget: Maryland Geological Survey Report no. 48

Langland, M., and Cronin, T. M., eds., 2003, A Summary Report of Sediment Processes in Chesapeake Bay and Watershed: U. S. Geological Survey Water-Resources Investigations Report 03-4123.

Ludwick, J. C., 1974, Tidal currents and zig-zag sand shoals in a wide estuary entrance: Geological Society of America Bulletin, v. 85, p. 717-726. 
Miller, A. J., 1987, Shore erosion as a sediment source to the tidal Potomac River, Maryland and Virginia: U.S. Geological Survey Water Supply Paper 22234-E, 45 p.

Norcross, J.J., and Stanley, E.M., 1967, Inferred surface and bottom drift, June 1963 through October 1964. Circulation of shelf waters off the Chesapeake Bight: Environmental Science Service Administration, v. 3, p. 11-42.

Orth, R. R., and Moore, K. A., 1983, Chesapeake Bay: An unprecedented decline in submerged aquatic vegetation: Science, v. 222, p. 51-53.

Orth, R. R., Moore, K., Fishman, J., Wilcox, D., Karrh, L., and Parham, T., 2002, Causes of submerged aquatic vegetation declines in Tangiers Sound, Chespapeake Bay: Chesapeake Bay Program Report, 133 p.

Traverse, A., 1988, Paleopalynology: Boston, Unwin Hyman, 600 p.

Willard, D. A., and Korejwo, D. A., 2000, Holocene palynology from Marion-Dufresne cores MD-2209 and 2207 from Chesapeake Bay: Impacts of climate and historic land use change, in Cronin, T. M., ed., Initial Report on IMAGES V Cruise of the Marion-Dufresne to Chesapeake Bay, June 20-22, 1999: U.S. Geological Survey Open-file Report 00-306. 


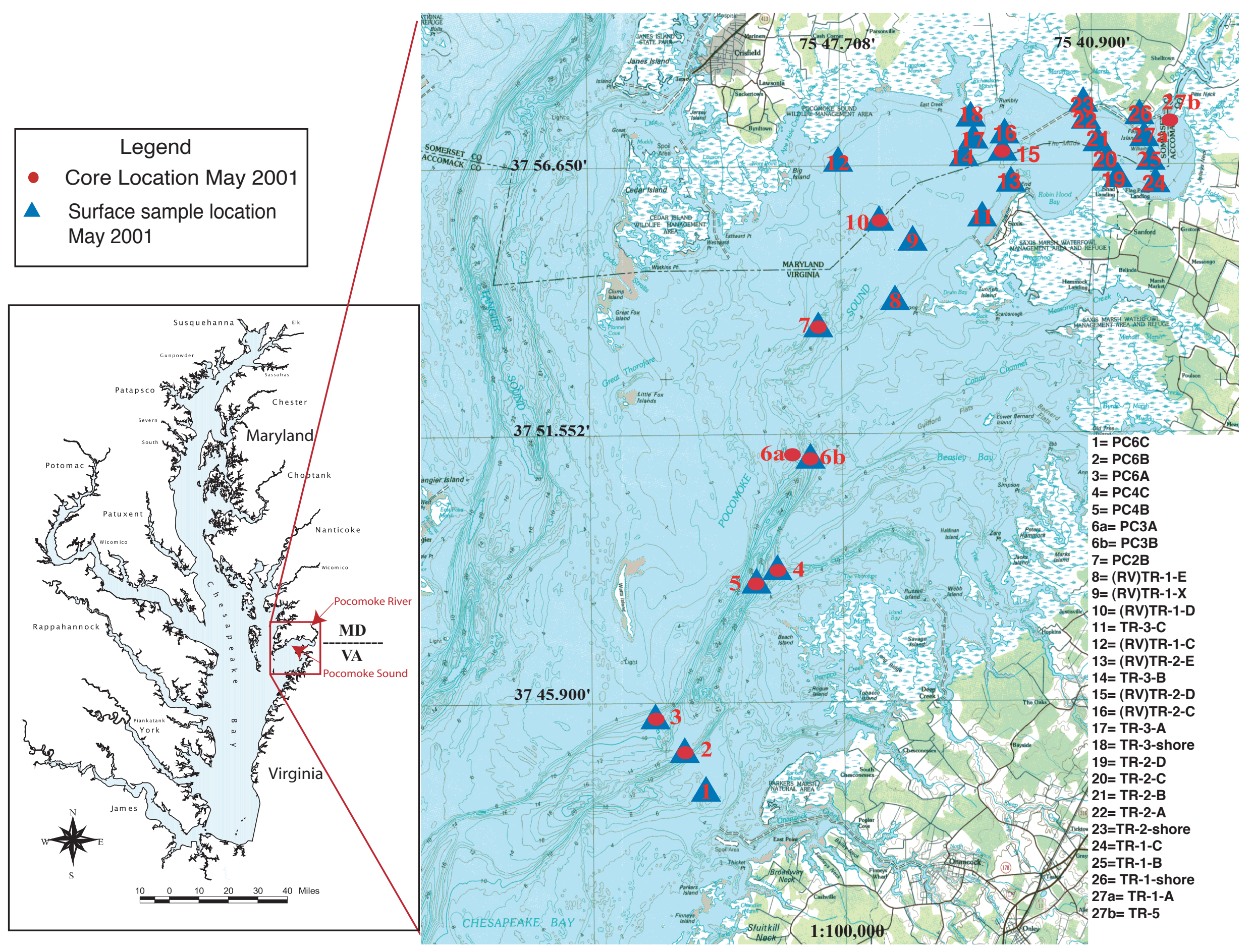

Figure 1.1. Map of Pocomoke Sound showing locations of sediment cores (red circles) and surface samples (blue triangles). 

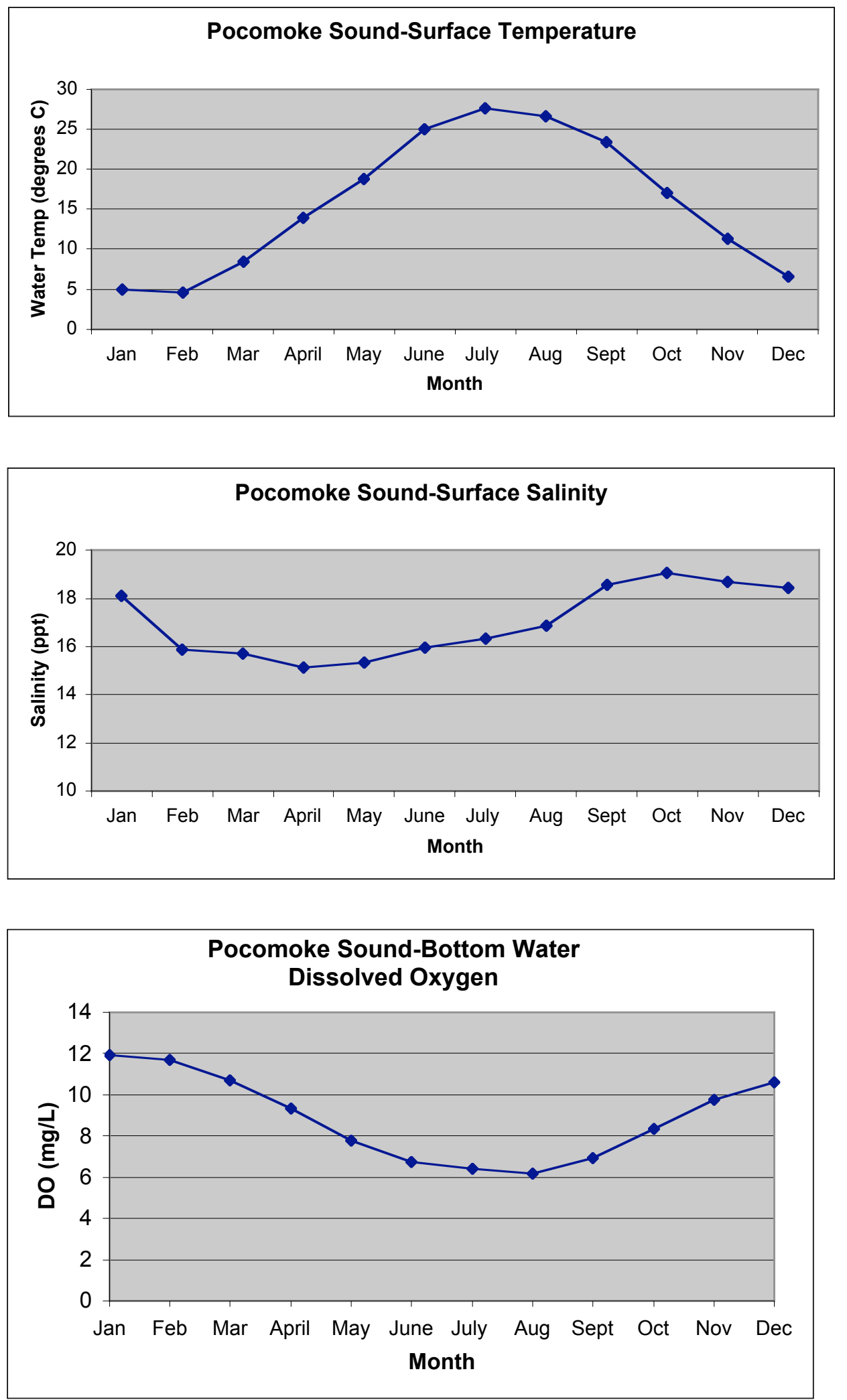

Figure 1.2. Mean monthly water temperature, salinity and bottom water dissolved oxygen for Pocomoke Sound from Chesapeake Bay Program monitoring stations. 

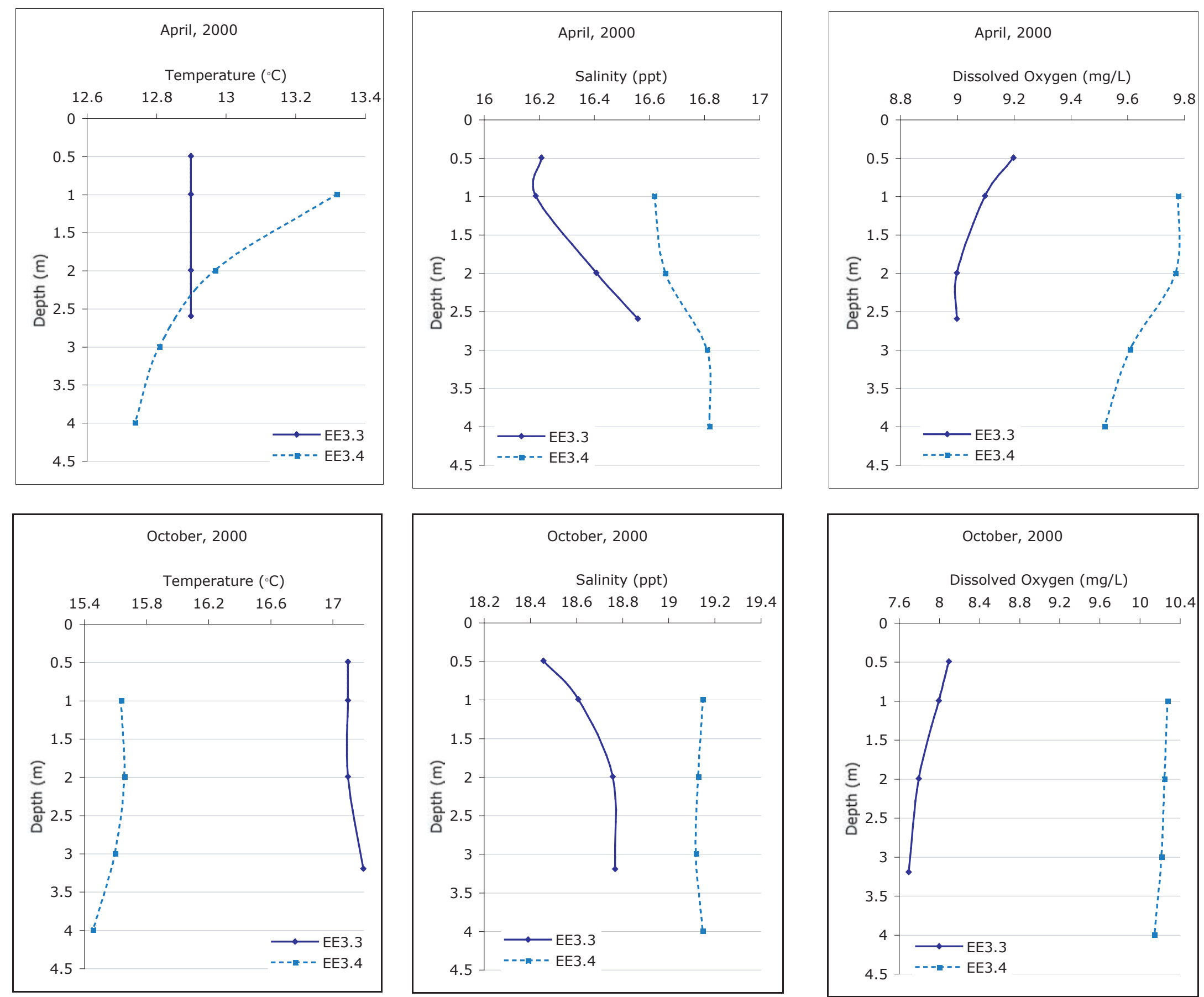

Figure 1.3. Vertical change in water temperature, salinity, and dissolved oxygen at Pocomoke Sound Chesapeake Bay Program stations EE3.3 and EE3.4 for April and October, 2000. 

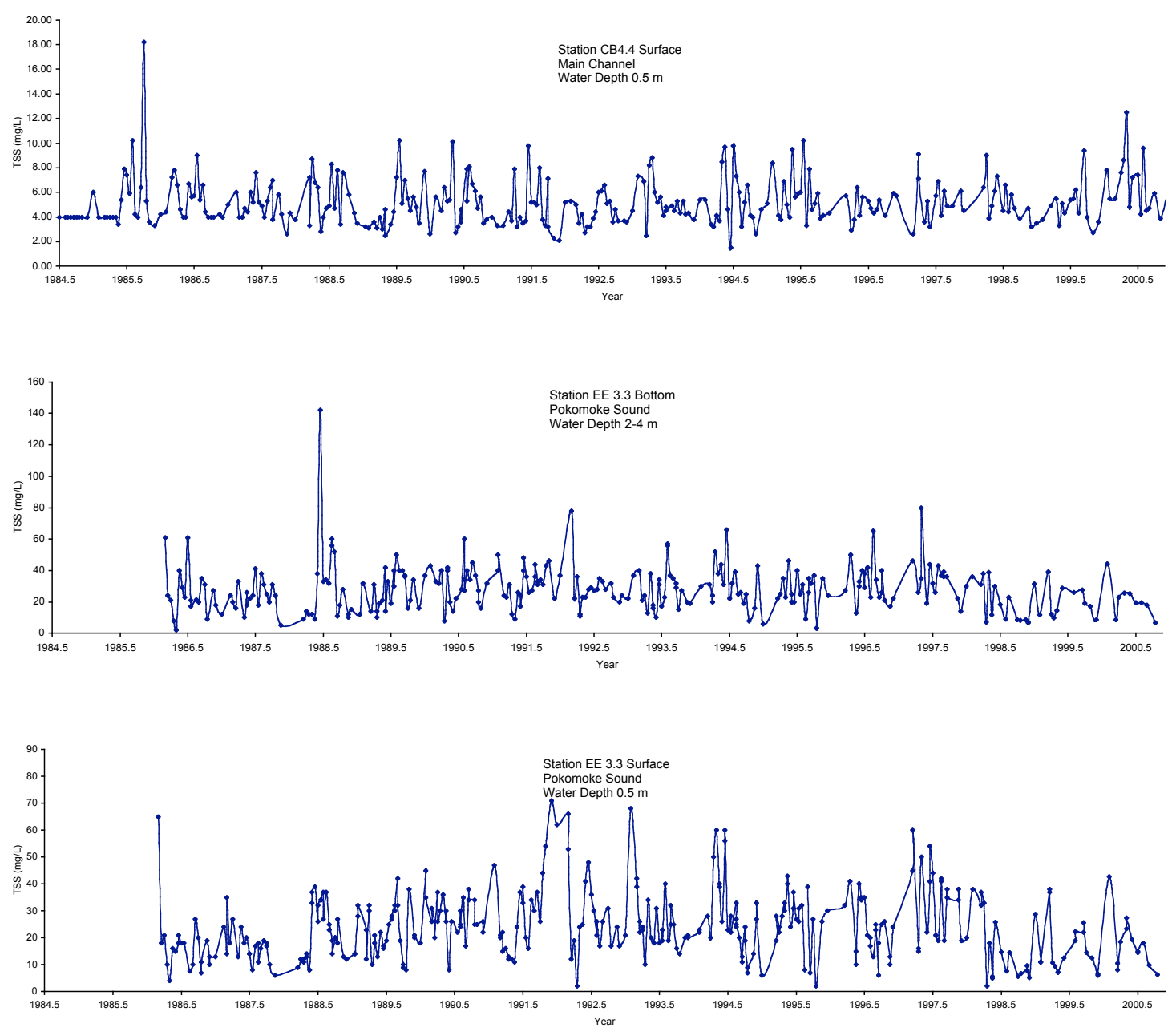

Figure 1.4. Seasonal and interannual variability in surface and bottom total suspended solids (TSS) for mainstem Chesapeake Bay (station CB4.4) contrasted with Pocomoke Sound (station EE3.4). 

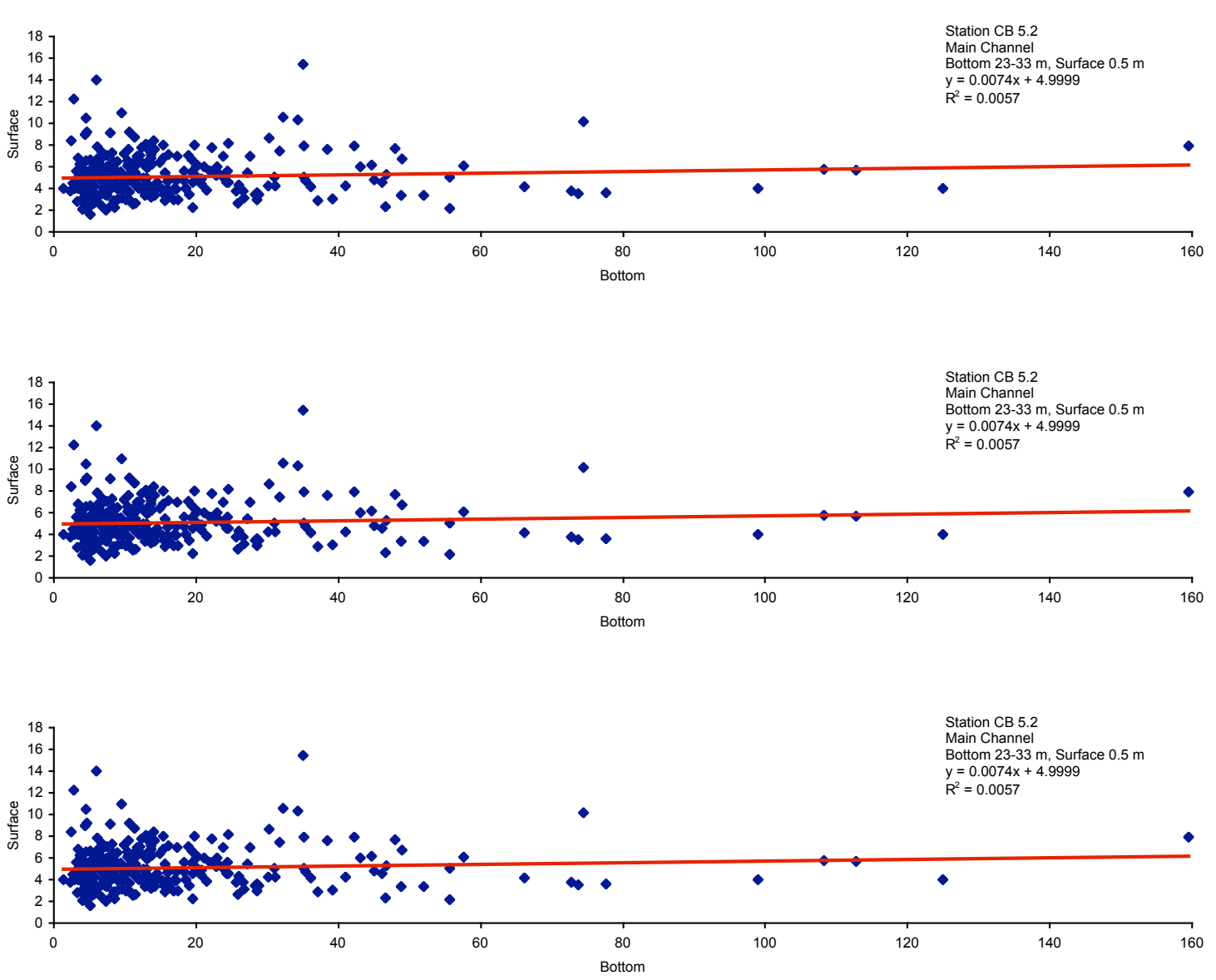

Figure 1.5. Relationships between bottom and surface TSS at mainstem station CB5.2 and Pocomoke Station EE3.4 (upper two plots) and between surface TSS at Pocomoke stations EE3.3 and EE3.4 (bottom plot). See text. 
Table 1.1. Pocomoke Sound Core Locations

\begin{tabular}{cccccc} 
Core Site & Dates of Cruise & Latitude & Longitude & Water Depth $(\mathrm{m})$ & Core Length $(\mathrm{cm})$ \\
\hline PC6B & May 15-16, 2001 & $37^{\circ} 44.910$ & $75^{\circ} 52.334$ & 14.6 & 169 \\
PC2B & May 15-16, 2001 & $37^{\circ} 53.429$ & $75^{\circ} 48.408$ & 7.9 & 200 \\
PC3B & May 15-16, 2001 & $37^{\circ} 50.741$ & $75^{\circ} 48.745$ & 11.4 & 177 \\
PC4B & May 15-16, 2001 & $37^{\circ} 48.300$ & $75^{\circ} 50.301$ & 27.3 & 122 \\
TR-5 & May 15-16, 2001 & $37^{\circ} 57.086$ & $76^{\circ} 38.880$ & 1.9 & 96 \\
TR-2-D & May 15-16, 2001 & $37^{\circ} 57.037$ & $75^{\circ} 43.516$ & 3.4 & 100 \\
TR-1-D & May 15-16, 2001 & $37^{\circ} 55.766$ & $75^{\circ} 46.868$ & 3.8 & 159 \\
PC3A & May 15-16, 2001 & $37^{\circ} 50.748$ & $75^{\circ} 49.138$ & 8.1 & 100 \\
PC4C & May 15-16, 2001 & $37^{\circ} 48.496$ & $75^{\circ} 49.820$ & 7.3 & 139 \\
PC6A & May 15-16, 2001 & $37^{\circ} 45.631$ & $75^{\circ} 52.815$ & 8 & 480 \\
& & & & 7.9 & 485 \\
PC2B-2 & September 17-19,2001 & $37^{\circ} 53.433$ & $75^{\circ} 48.409$ & 7.9 & 479 \\
PC2B-3 & September 17-19,2001 & $37^{\circ} 53.435$ & $75^{\circ} 48.409$ & 15.3 & 4.9 \\
PC2B-4 & September 17-19,2001 & $37^{\circ} 53.432$ & $75^{\circ} 48.406$ & 15.3 & 444.5 \\
PC6B-2 & September 17-19,2001 & $37^{\circ} 44.913$ & $75^{\circ} 52.333$ & &
\end{tabular}


Table 1.2 - Locations of surface sampling, Pocomoke Sound, Maryland.

\begin{tabular}{|c|c|c|c|c|}
\hline Site & Date & Latitude (N) & Longitude (W) & Water Depth (m) \\
\hline (RV)TR-1-C & $16 / 5 / 01$ & $37^{\circ} 56.821^{\prime}$ & $75^{\circ} 47.664^{\prime}$ & 3 \\
\hline (RV)TR-1-D & $15 / 5 / 01$ & $37^{\circ} 55.766^{\prime}$ & $75^{\circ} 46.868^{\prime}$ & 3.8 \\
\hline (RV)TR-1-E & $15 / 5 / 01$ & $37^{\circ} 54.445^{\prime}$ & $75^{\circ} 45.944^{\prime}$ & 3.6 \\
\hline (RV)TR-1-X & $15 / 5 / 01$ & $37^{\circ} 55^{\prime}$ & $75^{\circ} 46^{\prime}$ & 3.7 \\
\hline (RV)TR-2-C & $16 / 5 / 01$ & $37^{\circ} 57.402^{\prime}$ & $75^{\circ} 43.585^{\prime}$ & 2.6 \\
\hline (RV)TR-2-D & $16 / 5 / 01$ & $37^{\circ} 57.037^{\prime}$ & $75^{\circ} 43.516^{\prime}$ & 3.4 \\
\hline (RV)TR-2-E & $16 / 5 / 01$ & $37^{\circ} 56.758^{\prime}$ & $75^{\circ} 43.442^{\prime}$ & 3.4 \\
\hline PC2B & $15 / 5 / 01$ & $37^{\circ} 53.429^{\prime}$ & $75^{\circ} 48.408^{\prime}$ & 7.9 \\
\hline PC3B & $15 / 5 / 01$ & $37^{\circ} 50.741^{\prime}$ & $75^{\circ} 48.745^{\prime}$ & 11.4 \\
\hline PC4B & $15 / 5 / 01$ & $37^{\circ} 48.300^{\prime}$ & $75^{\circ} 50.301^{\prime}$ & 27.3 \\
\hline PC4C & $15 / 5 / 01$ & $37^{\circ} 48.496^{\prime}$ & $75^{\circ} 49.820^{\prime}$ & 7.3 \\
\hline PC6A & $15 / 5 / 01$ & $37^{\circ} 45.631^{\prime}$ & $75^{\circ} 52.815^{\prime}$ & 8 \\
\hline PC6B & $15 / 5 / 01$ & $37^{\circ} 44.910^{\prime}$ & $75^{\circ} 52.334^{\prime}$ & 14.6 \\
\hline PC6C & $15 / 5 / 01$ & $37^{\circ} 44.266^{\prime}$ & $75^{\circ} 51.927^{\prime}$ & 7.3 \\
\hline Poke Rvr T-3 & $14 / 5 / 01$ & $38^{\circ} 04.126^{\prime}$ & $75^{\circ} 34.878^{\prime}$ & 3 \\
\hline $\mathrm{T}-1$ & $14 / 5 / 01$ & $37^{\circ} 58.842^{\prime}$ & $75^{\circ} 37.831^{\prime}$ & 1.4 \\
\hline TR-1A & $15 / 5 / 01$ & $37^{\circ} 57.157^{\prime}$ & $75^{\circ} 39.422^{\prime}$ & 1.25 \\
\hline TR-1-B & $15 / 5 / 01$ & $37^{\circ} 57.019^{\prime}$ & $75^{\circ} 39.353^{\prime}$ & 2.1 \\
\hline TR-1-C & $15 / 5 / 01$ & $37^{\circ} 56.602^{\prime}$ & $75^{\circ} 39.242^{\prime}$ & 1.8 \\
\hline TR-1-Shore & $15 / 5 / 01$ & $37^{\circ} 57.208^{\prime}$ & $75^{\circ} 39.405^{\prime}$ & 0 (on shore) \\
\hline TR-2-A & $15 / 5 / 01$ & $37^{\circ} 57.811^{\prime}$ & $75^{\circ} 40.605^{\prime}$ & 1.4 \\
\hline TR-2-B & $15 / 5 / 01$ & $37^{\circ} 57.249^{\prime}$ & $75^{\circ} 40.456^{\prime}$ & 2 \\
\hline TR-2-C & $15 / 5 / 01$ & $37^{\circ} 56.717^{\prime}$ & $75^{\circ} 40.316^{\prime}$ & 1.8 \\
\hline TR-2-D & $15 / 5 / 01$ & $37^{\circ} 56.473^{\prime}$ & $75^{\circ} 40.257^{\prime}$ & 1.6 \\
\hline TR-2-Shore & $15 / 5 / 01$ & $37^{\circ} 58.048^{\prime}$ & $75^{\circ} 40.665^{\prime}$ & 0 (on shore) \\
\hline TR-3-A & $15 / 5 / 01$ & $37^{\circ} 57.513^{\prime}$ & $75^{\circ} 44.151^{\prime}$ & 1.5 \\
\hline TR-3-B & $15 / 5 / 01$ & $37^{\circ} 57.085^{\prime}$ & $75^{\circ} 44.098^{\prime}$ & 1.9 \\
\hline TR-3-C & $16 / 5 / 01$ & $37^{\circ} 55.846^{\prime}$ & $75^{\circ} 44.084^{\prime}$ & 1.9 \\
\hline TR-3-Shore & $15 / 5 / 01$ & $37^{\circ} 57.787^{\prime}$ & $75^{\circ} 44.212^{\prime}$ & 0 (on shore) \\
\hline
\end{tabular}

$\mathrm{RV}$ means taken on RV Kerhin with Van Veen grab sampler except those in $<3 \mathrm{~m}$, taken by hand sampler 


\title{
Chapter 2. Sediment and chemical flux history in the Pocomoke Sound as defined by short lived isotopic analyses
}

\author{
C. W. Holmes* and M. Marot*
}

*U. S. Geological Survey St. Petersburg, Florida 33701

\section{Introduction}

Pocomoke Sound, located in the southeastern part of Chesapeake Bay on the eastern shore of the central Delmarva Peninsula, is an ecologically threatened region in terms of water clarity, turbidity, dissolved oxygen, and the health of its submerged aquatic vegetation and the organisms that use this important habitat. Excess nutrient and sediment loads have resulted in excessive algal growth, oxygen depletion, and increased turbidity within the water column. For example, a six-year record (1986-1992) shows that dissolved oxygen in this mesohaline water body is depleted, especially during the summer months (www.@baylink.org/atlas/). Increased turbidity is also a serious problem because it affects light reaching submerged aquatic vegetation living along the margins of Pocomoke Sound.

In order to determine processes that influence the sedimentary dynamics of the region, a study on short-lived isotopes and trace elements was conducted during the years 2001 and 2002. The short-lived isotopes, ${ }^{7} \mathrm{Be},{ }^{137} \mathrm{Cs}$, and ${ }^{210} \mathrm{~Pb}$ are unique tracers of sediment in space and time and these isotopes were measured in surface samples and cores collected in the spring and fall of 2001. It was determined that from 1890 to about 1940, a significant portion of the sediment originated within the watershed. Between 1940 and 1950 there was a shift is sediment sources, with bank erosion becoming a prominent source. During this transition, the higher concentrations of redox sensitive elements (U, Mo, and Re) suggest that Pocomoke Sound was hypoxic. These changes can be directly linked to anthropogenic changes in the watershed. The results of the study demonstrated that the short lived isotopes are valuable in understanding changes in sediment regimes and with addition data may be useful in modeling the sedimentary dynamics of the area.

Short-lived radioisotopes, ${ }^{7} \mathrm{Be},{ }^{137} \mathrm{Cs}$, and ${ }^{210} \mathrm{~Pb}$, are unique spatial and temporal tracers of sediment processes. ${ }^{210} \mathrm{~Pb}$ has been used extensively to detail the sedimentary 
record in Chesapeake Bay for over the last half century, but rarely in combination with ${ }^{137} \mathrm{Cs}$ or ${ }^{7} \mathrm{Be}$. Each isotope is introduced into the sediment via atmospheric fallout, thus the isotopes are deposited at nearly uniform activities across the region. Natural physical processes of erosion, transportation, and deposition deplete the sediment isotopic concentrations in some areas and concentrate them in others. Knowledge of the initial atmospheric flux of radioisotopes and their distribution in the depositional basin makes it possible to determine the dynamics of erosion, transport and deposition within the watershed. In this study, sedimentary processes in Pocomoke Sound and its surrounding watershed were investigated, (1) by defining the depositional centers with ${ }^{7} \mathrm{Be},(2)$ by using high-resolution profiles of ${ }^{210} \mathrm{~Pb}$ and ${ }^{137} \mathrm{Cs}$ to define sediment accumulation rates, and (3) by defining environmental changes by chemical indices.

Study area -- Pocomoke Sound was formed by the erosion of the ancient Pocomoke River during lower sea level during Pleistocene glacial advances (Figure 2.1). Today, this river is the primary drainage for the south central part of the Delmarva Peninsula. The $\sim 700$ square mile watershed is $40 \%$ agricultural lands, $38 \%$ forests, $18 \%$ wetlands, $1.25 \%$ urbanized, and less than $>1.5 \%$ coastal marsh lands. These proportions have changed little since the middle of the $20^{\text {th }}$ century.

The terrestrial portion of the Delmarva Peninsula is topographically low. As land was cleared for habitation and farming, an extensive drainage system was constructed. This ditching, initiated in colonial times, has continued up to the present. Prior to the 1940's, the practice was limited. During and immediately after World War II, land reclamation increased, peaking in the early 1970's (Iivari, 1991). This was a time of massive row crop farming with a significant use of fertilizer (Zimmerman and Canuel, 2000). In early 1980's, many weirs were constructed to trap sediment (Iivari, 1991). Row-crop farming decreased at the same time, while poultry production increased (Figure 2.2).

The subaqueous part of Pocomoke Sound can be conveniently divided into three geomorphic zones: (1) the lower Pocomoke River and associated tidal flats, (2) the Pocomoke River sub aqueous delta in the upper part of the sound, and (3) the non-filled incised relict river (Figure 2.1). The sinuous tidal river flows approximately 65 
kilometers from Pocomoke City to the mouth of the Sound. This portion of the river is monotonously deep ( $\sim 8$ meters) and $\sim 1 \mathrm{~km}$ wide, fringed with large tidal flats. The bottom of the river contains lag deposits. The tidal flats are comprised of very fine, highly water-saturated clays and marsh vegetation. Sediment deposition on the flats is the result of tidal lag deposition (van Straaten and Kuenen, 1958). In 1913, the Army Corps of Engineers began the dredging process to create a new passage through the mudflats at the mouth of the Pocomoke River, creating a straighter, more maneuverable navigation channel (Iivari, 1991).

In the upper part of the sound, between the Maryland boundary and Virginia's Freeschool marsh peninsula and Gulford Flats, is a large 20 square kilometer delta. The water depth on the delta varies between 1 and 2 meters. The Freeschool marsh and Gulford Flats are founded on very coarse sands and gravels suggesting that they formed on a buried barrier. Southwestward from the delta between the ridge and the southern Maryland boundary is the thalwag of the incised submerged Pleistocene Pocomoke River. Bottom samples indicate that the sediment in the central portion of the sound is texturally mud (silty-clay) which grades into the fine sand near the shorelines.

\section{Material and Methods}

This section describes material and methods used in analysis of surface sediment ${ }^{7} \mathrm{Be}$ inventories (data given in Appendix 2.1), radionuclide measurements of ${ }^{210} \mathrm{~Pb},{ }^{7} \mathrm{Be},{ }^{137} \mathrm{Cs}$, ${ }^{40} \mathrm{~K}$ and ${ }^{226} \mathrm{Ra}$ concentrations (data given in Appendix 2.2), and trace element distributions in sediment cores (data given in Appendices 2.3, 2.4). The radionuclide inventory of the sediment cores from Pocomoke Sound is summarized in Table 1. The detection limits of the "ultratrace" procedure used to measure trace metals in sediments from four cores are given in Table 2. Both tables are given at the end of this report.

Sampling Pocomoke Sound -- In April 2001, 18 surface samples were collected along the Pocomoke River at six locations from Pocomoke City down to the river mouth. At each location the uppermost $4 \mathrm{~cm}$ of sediment was collected from the thalwag and from each sidebank. In May 2001, 27 surface sediment samples were collected along 3 crossaxis transects in the upper Sound and at 3 deeper water sites in the lower Sound (Figure 
2.1). These sites were reoccupied in September $2001 .{ }^{7} \mathrm{Be}$ inventories were measured at each site to determine the spatial depositional pattern and identify areas of sediment storage.

For the retrospective analyses, four large volume push cores and one piston core were taken on along the axis of the sound. Three push cores were taken in the upper Sound on the subaqueous river delta. The fourth push core was collected on a tidal flat adjacent to the river to determine the history of sediment storage with the tidal flats. The piston core, taken in the deep channel in the lower Sound, integrated the sediment record from the Sound and the surrounding region.

The surface samples along the river were collected using an Ekman grab sampler. The surface samples in the Sound were collected by VanVeen and Ponar grab samplers. The Ekman and VanVeen samplers were large enough to allow subsamples to be obtained by inserting a $10.25 \mathrm{~cm}$ diameter plastic core liner into the sediment and carefully extracting a subcore. Each subcore was visually inspected prior to sampling to verify the integrity of the sediment/water interface. If any indication of sediment disturbance was visible, the subcore was discarded. The extracted subcores were sectioned into $1-\mathrm{cm}$ intervals by inserting a piston in the bottom of the cylinder and carefully extruding the sediment in measured increments out the top of the core liner. Samples retrieved by the Ponar grab were a composite of the uppermost few centimeters of sediment.

The large volume cores were obtained by manually inserting a $10.25 \mathrm{~cm}$ diameter polycarbonate core liner into the sediment until refusal. The cores ranged in length from $45-70 \mathrm{~cm}$. Care was taken at all times to minimize disturbance of the sediment/water interface. The cores were returned to the laboratory and x-radiographed prior to sampling. The x-rays were used to look for internal sedimentary structure and signs of post-depositional disturbance. The sediment was extruded in the same manner as the surface samples. The top $10 \mathrm{~cm}$ were sectioned at $1 \mathrm{~cm}$ intervals and at a $2 \mathrm{~cm}$ interval below $10 \mathrm{~cm}$. Each section was weighed and the outermost sediment in contact with the core liner was removed to prevent contamination from smearing along the interior of the barrel. This method of sectioning resulted in depth intervals of known volume, allowing for direct calculation of bulk density, which is used in mass accumulation calculations. 
The deeper part of the bay was sampled with an $\sim 3$-inch diameter piston corer. The total length of the core was $350 \mathrm{~cm}$. In the laboratory, this core was split horizontally. Half the core was archived and the other half was sampled into $2 \mathrm{~cm}$ intervals. The bulk densities of these samples were calculated using the water content to calculate the porosity and assuming $2.76 \mathrm{~g} \mathrm{~cm}^{-3}$ as the particulate density.

In the laboratory, all samples were dried in an oven at $60^{\circ} \mathrm{C}$ for at least 48 hours to determine water content. The dried samples were ground by hand to a fine powder using a ceramic mortar and pestle. Five grams of material was taken from each sample for loss on ignition (LOI). The material was heated in a muffle furnace for 6 hours at $450^{\circ} \mathrm{C}$. The percent weight loss is an index of organic content. The material remaining after LOI was then used for ${ }^{210} \mathrm{~Pb}$ analysis. A split ( 1-2 grams wet) was taken for grain size analysis from each interval in the four push cores prior to drying. Grain size distributions were measured with a Beckman Coulter LS200 Particle Analyzer.

Radionuclide measurements -- ${ }^{210} \mathrm{~Pb}$ activities were determined by measuring the activity of its granddaughter ${ }^{210} \mathrm{Po}$, with the assumption that the two isotopes are in secular equilibrium. Because ${ }^{210}$ Po has a relatively short half-life (138 days), secular equilibrium is quickly established with its parent isotopes. ${ }^{210} \mathrm{Po}$ is chemically leached from the sediment and autoplated onto a silver planchet for counting by alpha spectroscopy (Flynn, 1968). During the dissolution of the sample, a known amount of the tracer radioisotope ${ }^{209}$ Po is added. By comparison of the known activity of the tracer to that of the sample unknown, the ${ }^{210} \mathrm{~Pb}$ activity in the sample is calculated. Triplicate analyses performed of a subset of samples defined the combined analytical and counting errors at $5 \%$.

The ${ }^{7} \mathrm{Be},{ }^{137} \mathrm{Cs},{ }^{40} \mathrm{~K}$ and ${ }^{226} \mathrm{Ra}$ concentrations were determined by gamma spectroscopy. The analyses were made with a Canberra low energy germanium detector coupled to a multi-channel analyzer. Detector efficiency was calibrated using a NISTtraceable standard. All activities are decay corrected to the date of sample collection. ${ }^{226} \mathrm{Ra}$ was measured by averaging the activity its progeny ${ }^{214} \mathrm{~Pb}$ and ${ }^{214} \mathrm{Bi}$. The samples were stored in a sealed counting jar for a minimum of two weeks prior to analysis to insure radioactive equilibrium is established between ${ }^{226} \mathrm{Ra}$ and its progeny. 
Trace element analysis-- The trace element distribution in the sediment from core PC6B-3 was determined by a semi-quantitative method, whereas, the trace metals in sediments from the four cores were determined by what is referred to as the "ultratrace" procedure (Table 2). The latter procedure has a lower detection limit, which translates to higher degree of precision. Because the trace metals in the two data sets were measured by different methods, comparisons must be made with caution. However, where the measured of concentration is significantly higher than the lower limit of detection, such as in the case of zinc, comparisons between the two data sets may be appropriate.

To reduce the potential for operator error, the samples were randomized prior to submission. In addition, $20 \%$ of the samples were submitted in duplicate. The results indicate that for lithic elements, those elements that are part of mineral structure, the deviation ranged from 5 to $7 \%$, whereas those elements which are adsorbed on the particles, and therefore more easily brought into solution, the deviation is less than $2 \%$.

\section{Results and Discussion}

Seasonal Record $-{ }^{7} \mathrm{Be}$, formed in the atmosphere by the collision of cosmic rays with oxygen and nitrogen, has a short half-life ( $<54$ days) and is a very particle reactive. The short half-life and geochemistry make ${ }^{7} \mathrm{Be}$ useful for measuring the dynamics of active sedimentary processes. It also is useful in defining fluxes of other isotopes, such as ${ }^{210} \mathrm{~Pb}$ and ${ }^{137} \mathrm{Cs}$. The centers of active deposition are located by mapping the ${ }^{7} \mathrm{Be}$ inventory (Appendix 2.1). The inventory is defined as the total amount of ${ }^{7} \mathrm{Be}\left(\mathrm{dpm} / \mathrm{cm}^{2}\right)$ at a sample site. The region with the highest inventory is a center of deposition. By making seasonal inventory maps, seasonal changes in depocenters are defined.

${ }^{7}$ Be inventory in Pocomoke Sound varied from $7.6 \mathrm{dpm} \mathrm{cm}^{-2}$ at the mouth of the Pocomoke River to undetectable near the shorelines. Within the tidal portion of the river, ${ }^{7}$ Be varied between 0.6 to $2.2 \mathrm{dpm} \mathrm{cm}^{-2}$; detectable and constant on the flats but absent, with the exception of one site, in the thalwag. The highest value $\left(7.7 \mathrm{dpm} \mathrm{cm}^{-2}\right)$ occurs at the mouth of the river; ${ }^{7} \mathrm{Be}$ is also high on both banks and on the upstream side of the river mouth deposit (Figure 2.3A). This value is similar to the $6.8 \mathrm{dpm} \mathrm{g}^{-1}$ measured in suspended sediment, sampled in August 2002. 
The highest activity $\left(2.0 \pm 0.2 \mathrm{dpm} \mathrm{g}^{-1}\right)$ in the sound occurs in the deeper part of the system. There are slight differences between the spring (May) and fall (September). The sites on the riverside of the bay-mouth delta showed the most significant change. In the spring, ${ }^{7} \mathrm{Be}$ was detected only on the seaward side of the deposit. In the fall, ${ }^{7} \mathrm{Be}$ was detected both on the riverside and seaward side of the delta. This suggests that during the spring runoff much of the sediment by passes the bay-mouth deposit. The "weaker" transporting energy in the summer and fall permits some sediment to be trapped on the delta.

${ }^{7} \mathrm{Be}$ is also valuable in estimating $\left(\mathrm{A}_{\mathrm{o}}\right)$, a parameter essential in calculating ${ }^{210} \mathrm{~Pb}$ chronologies. The short half-life of ${ }^{7} \mathrm{Be}$ makes this isotope ideal for this purpose, because the presence of ${ }^{7} \mathrm{Be}$ is evidence that the sediment was being transported within the last few months. By using ${ }^{7} \mathrm{Be}$, it was determined that the surface ${ }^{210} \mathrm{~Pb}$ activity was $\sim 4.0$ $\mathrm{dpm} / \mathrm{g}$.

Lead -210 -- ${ }^{210} \mathrm{~Pb}$ is a decay product within the uranium $\left({ }^{238} \mathrm{U}\right)$ series. Radioactive equilibrium occurs when the activity of each successive isotope in a radioactive series has the same activity. Disequilibrium occurs when the series is broken. In nature, the ${ }^{238} \mathrm{U}$ series is broken by the diffusion of ${ }^{222} \mathrm{Rn}$ from minerals exposed at the earth's surface. ${ }^{222} \mathrm{Rn}$ escapes into the atmosphere at a rate of $\approx 42$ atoms per minute per square centimeter of land surface (Faure, 1986). With a half-life of 3.8 days, ${ }^{222} \mathrm{Rn}$ decays rapidly leading to the formation of ${ }^{210} \mathrm{~Pb}$ through a series of very short half-life isotopes. This process produces excess ${ }^{210} \mathrm{~Pb}$ in the atmosphere, from which it is purged by wet and dry deposition. Like ${ }^{7} \mathrm{Be}$, this isotope is particle reactive and once in the surface environment it is rapidly adsorbed on sediment.

There have been many ${ }^{210} \mathrm{~Pb}$ age models developed. Robbins (1978), Oldfield and Appleby (1984), and Carroll and others (1995), Robbins and others (2001) Nie and others, (2001) have review the various methods, applications and approaches to ${ }^{210} \mathrm{~Pb}$ age modeling. The chronologic model used in this study, developed by Robbins and others (2001), is a simple first order model. In this model the atmospheric ${ }^{210} \mathrm{~Pb}$ flux and accumulation rate is assumed to be constant and any variability with the exception of ${ }^{210} \mathrm{~Pb}$ decay is averaged by sedimentological processes. Results are given in Appendix 
2.2. The surface activity is assumed to be constant and equal to the flux of ${ }^{210} \mathrm{~Pb}$ divided by the sediment accumulation rate in grams per square centimeter. This parameter was determined from the surface activity by the ${ }^{7} \mathrm{Be}$. Excess ${ }^{210} \mathrm{~Pb}$ activity $\left(\mathbf{A}_{\mathbf{e x}}\right)$ for a given interval is defined as the difference between the total ${ }^{210} \mathrm{~Pb}$ and ${ }^{226} \mathrm{Ra}$, and is calculated as follows:

$$
\mathrm{A}_{\mathrm{ex}}=\mathrm{F} / \mathrm{R}_{\mathrm{s}} \mathrm{e}^{-\mathrm{-}(\mathrm{g} / \mathrm{Rs})}
$$

where $\mathrm{g}$ is accumulative weight of sediment $\left(\mathrm{g} \mathrm{cm}^{-2}\right), \mathrm{F}$ is flux $\left(\mathrm{dpm} \mathrm{cm}{ }^{2} \mathrm{yr}^{-1}\right), \mathrm{R}_{\mathrm{s}}$ is accumulation rate $\left(\mathrm{g} / \mathrm{cm}^{2} / \mathrm{yr}\right), \square$ is the decay constant of ${ }^{210} \mathrm{~Pb}\left(\ln 2 / \mathrm{t}^{1 / 2}=0.03114\right)$. This equation takes in to account sediment compaction and implicitly assumes no postdepositional mobility, sediment mixing or changes in sediment supply.

Numerous investigators have addressed post depositional ${ }^{210} \mathrm{~Pb}$ mobility and in most environments this is not a problem (Urban and others, 1990). The degree of mixing is assessed by examination of x-radiographs, and indirectly by the nature of the trace metals profiles. The Pocomoke sound core $\mathrm{x}$-radiographs show significant layering. The layers range from 2 to $\sim 10 \mathrm{~cm}$. in thickness. Therefore, if mixing is present, it occurs only within these layers.

A "best fit" curve of the measured data was calculated by least-squares optimization using the Marquardt-Levenberg (M-L) methods. Using the age formula (1), the ages of each level in the cores was calculated. These ages were used to compare with other data. While the age assignments are calculated from the accumulative weight of the sediment, the results are displayed in linear depth units. This procedure yields a first order age model. Comparing the best-fit curves (the "ideal curves") to raw data shows the degree to which the data conform to the ideal.

The best-fit data for the six cores shows that each have a very good and significant "goodness of fit" with the $\mathrm{R}^{2}$ values ranging from a low of 0.88 in the core data from the tidal flat to 0.98 for the deepest core on the Pocomoke delta. The $\mathrm{r}^{2}$ values for the other cores varied between 0.97 and 0.96 (Figure 2.5). Core 1 has the highest $r^{2}$ value.

The very high $\mathrm{r}^{2}$ values indicate that the ${ }^{210} \mathrm{~Pb}$ chronologies are a good first order approximation. Using the estimated chronologies, the average accumulation rates can be calculated. Cores 2 and 3 have an average accumulation rate of 0.25 and $0.29 \mathrm{~cm} \mathrm{yr}^{-1}$ 
respectively. On the seaward side of the bay mouth deposit, the average accumulation rate (Core 1) was calculated to be $0.47 \mathrm{~cm} \mathrm{yr}^{-1}$. The highest rate was calculated to be 1.8 $\mathrm{cm} / \mathrm{yr}$ in the thalwag of the incised river valley. On the tidal flat, the sediment was calculated to be accumulating at an average of $0.62 \mathrm{~cm} \mathrm{yr}^{-1}$.

Examination of the raw data against the "ideal" curve for each core is very revealing. With the exception of Core 1 whose excess ${ }^{210} \mathrm{~Pb}$ almost perfectly reflects the ideal curve, the top portions of Cores 2, 3, 4, and 6 fall above the ideal curves. Close examination of this portion of these curve shows that the slopes of these data is much shallower than the data deeper in the core. This shallow slope is suggestive of more rapid accumulation than the calculated average rates. The calculated age at the point of cross over varied between $1953^{+/} 4 \mathrm{yrs}$ in core 1 to $1959^{+/} 4$ yrs on the tidal flat. There is a suggestion that in the top portion of the cores, the ${ }^{210} \mathrm{~Pb}$ has a shallower slope.

Cesium-137 -- In July 1945, nuclear weapon tests began releasing ${ }^{137} \mathrm{Cs}$ and other radioactive nuclides into the environment for the first time. Over the 50 years since those tests, much research has been done to understand the movement and fate of the radionuclides in the environment. Beginning in the late 1950's many atmospheric radiological monitoring stations were established around the country. The closest to Chesapeake Bay region is in Sterling Va. The ${ }^{137} \mathrm{Cs}$ record was derived from the ${ }^{90} \mathrm{Sr}$ depositional record. Using the ${ }^{90} \mathrm{Sr} /{ }^{137} \mathrm{Cs}$ ratio measured by the atmospheric sampling program for the $1959-1963$ period, ${ }^{137} \mathrm{Cs}$ was found to be 1.32 times the ${ }^{90} \mathrm{Sr}$ activity (www.eml.doe.gov/databases/). The ${ }^{137} \mathrm{Cs}$ fallout records from the central and northeastern portion of the country are all similar in terms of total inventory, thus it is assumed to be universal through the watershed and sound. Radiological fallout varied with the number and magnitude of nuclear test. The record shows the largest fluxes occurred during the early 1962-1963 and declined after the ratification of the Nuclear Test Ban Treaty (Figure 2.6).

Overlying the ${ }^{137} \mathrm{Cs}$ distribution on the ${ }^{210} \mathrm{~Pb}$ time scale shows that the ${ }^{137} \mathrm{Cs}$ peak in cores 1, 2, 3 coincide with 1962-1963 maximum production (figure 2.7). This confirms the ${ }^{210} \mathrm{~Pb}$ chronology. ${ }^{137} \mathrm{Cs}$ distribution in core 4 is different. In this core, the ${ }^{137} \mathrm{Cs}$ flux increases from the late 1950 's to a maximum after 1980 . In core $6,{ }^{137} \mathrm{Cs}$ 
activity ranges from less than 0.1 to a maximum of $0.86 \mathrm{dpm} \mathrm{g}^{-1}$. These values translate to a range of fluxes form a low of 1 to a maximum of $5.4 \mathrm{dpm} \mathrm{cm}^{-2} \mathrm{yr}^{-1}$. The maximum concentration does not match the peak production but peaks between 1966 and 1967. This shift or delay in maximum ${ }^{137} \mathrm{Cs}$ has been recognized by others (Robbins et al. 2001 and Nie et al. 2001). This time delay is believed to be a function of varying rates of erosion and transportation of sediment from the supplying watershed. In addition, there is a secondary concentration peak that apparently correlates with an event which occurred in 1972. This is the year of Hurricane Agnes, which was a major sedimentological event in Chesapeake Bay region (Nie et al., 2001; Helz et al., 1985).

Trace metals and sediment texture -- The trace metals concentrations in the Pocomoke Sound sediments the fall into four categories: fine sediment lithic, coarse sediment lithic, anthropogenic, and authigenic (Appendices 2.3, 2.4). The fine sediment lithic elements are those elements (Al, B, K, Cr, Ni, Ga, Rb, Tl, Th, and the rare earths) that are associated with the crystalline structure or adsorbed on the fine silts and clays. The coarse sediment lithic is those elements ( $\mathrm{Li}, \mathrm{Mg}, \mathrm{Ca}, \mathrm{Ba}, \mathrm{Mn}, \mathrm{Fe}, \mathrm{Co}$ ), which are associated with coarser silts and sands. The anthropogenic elements $(\mathrm{Cu}, \mathrm{Zn}, \mathrm{As}, \mathrm{Se}, \mathrm{Cd}$, $\mathrm{Sb}, \mathrm{Bi}$ ) are derived from anthropogenic sources. As these elements are used as additives in a variety of manufactured products (such as tires, fertilizers etc.) a single source is difficult to name. The authigenic elements (U, Mo, and $\mathrm{Re})$ are those that react to changing redox conditions in the system.

The authigenic redox sensitive elements (U, Mo, and sometimes V) are concentrated in sediments by changes in the physiochemical conditions of the water (Morford and Emerson, 1999). The stable form of uranium in oxygenated waters is +VI. In marine waters this species forms a complex with carbonate ions. In anoxic systems, uranium is reduced to the insoluble + IV and is adsorbed on particlate material or is deposited as a sulfide. Molybdenum (VI) is the stable form in oxic systems and exists as $\mathrm{MoO}_{4}{ }^{-2}$ Reduction of Mo (VI) to Mo (IV) and authigenic enrichment of Mo in the sediment occurs under reducing conditions via precipitation across the sediment interface (Crusius and Thompson, 1996). Vanadium on occasion has the same properties as molybdenum element, but is also an element that mirrors iron. Because iron is ubiquitous 
it is difficult to separate the vanadium which is associated with iron from that which is reacting to oxic conditions.

The metal profiles in all cores are similar. Zinc, one of the easiest metals to measure and compare among cores (Figure 2.8), increased in concentration greatly, beginning in the late 1940s and early 1950s. This increase reached its maximum around the mid 1980's and remained constant until the present. The distribution of the redox sensitive elements (uranium and molybdenum) exhibits a decrease through the late 1900's. The spike in the late 1940's corresponds to the rapid changes in land used in the watershed (Figure 2.9) and suggests a short-term nearly anoxic interval in the Sound beginning shortly after the increase use of fertilizer during and immediately after World War II.

The core with the longest and best-resolved record is core PC-6B (Figure 2.10). In this core, the anthropogenic elements zinc and lead have the same pattern, increasing greatly between 1950 and 1970 (Figure 2.10). Lithic element(s) (i.e. aluminum) covaries with the organic index, loss on ignition, and are in opposition to sand percentages. The metal distribution also reflects changes in sediment intensity, with spikes occurring during Hurricane Agnes.

Size analysis of the sediment confirms that most of the sediment in the Sound is silty clay. There is an indication that the post 1950 sediment was slightly coarser. The organic content of the sediment, as measured by LOI, ranged from 4 to $8 \%$.

Conceptual Models - There have been many efforts to use short-lived isotopes to model the history of sedimentary dynamics in aqueous systems. Ritchie and Mc Henry (1990) proposed a box model that related the atmospheric fallout of ${ }^{137} \mathrm{Cs}$ to its distribution in the depositional basin. Edgington and Robbins (2000) successfully modeled 100 years of sediment transport in Lake Michigan using ${ }^{137} \mathrm{Cs}$. To develop a rigorous sediment transport model for any sedimentary system, analysis of many depositional sites is necessary. Although only five core sites were sampled in this study, they contain sufficient data on the Pocomoke Sound's sedimentary history to formulate preliminary sediment dynamics models. In an ideal equilibrium world (case 1), the distribution of the short-lived isotopes would follow physical laws, with isotopes introduced directly a 
basin of deposition in equilibrium with atmospheric flux. As a result, the ${ }^{137} \mathrm{Cs}$ record would mirror the atmospheric flux, and the concentration of ${ }^{210} \mathrm{~Pb}$, initially equal to the atmospheric flux, would decrease logarithmically with depth (Figure 2.11a). In this case the atmospheric to core inventory ratio for both isotopes would be one (Figure 2.12).

Ideal conditions rarely occur in a nature. Changes in climate, land use, or geophysical conditions, such as sea level rise, lead to changes in sedimentation on the time scales that can be measured by these isotopes. In a situation where much of the sediment in the basin is derived from the watershed (Case 2), the ${ }^{137} \mathrm{Cs}$ record in the basin would be a combination of the internal basin record and material added by erosion and transport from the watershed. The exact distribution would be a combination of natural and anthropogenic factors. In this case, the peak ${ }^{137} \mathrm{Cs}$ concentration would not necessarily match the fallout peak (1962-1963) but, depending on the timing and intensity of erosion and transport, would be younger. The over all ${ }^{210} \mathrm{~Pb}$ activity, due to focusing, would initially be higher. If this system were in equilibrium, the ${ }^{210} \mathrm{~Pb}$ profile with depth would have a logarithmic decrease (Figure 2.11b). In this case, the core inventory to atmospheric flux ratio would be greater than one for both ${ }^{137} \mathrm{Cs}$ and ${ }^{210} \mathrm{~Pb}$. Pulses of sediment would be reflected by abrupt increases in the general ${ }^{137} \mathrm{Cs}$ and ${ }^{210} \mathrm{~Pb}$ curves.

In a case where most of the sediment reaching the basin was exhumed, "old" sediment not exposed to the atmosphere during the late 1950's and early 1960's, the sediment would be depleted in ${ }^{137} \mathrm{Cs}$ (Case 3). However, because the atmospheric supply of ${ }^{210} \mathrm{~Pb}$ and ${ }^{7} \mathrm{Be}$ is continuous and, in most large systems, a large percentage is adsorbed on the sediment during transport, the record in the sediment would approximate the ideal (Figure 2.11c). In this case, the atmospheric to core inventory for ${ }^{137} \mathrm{Cs}$ would be much less than one, whereas the ${ }^{210} \mathrm{~Pb}$ ratio would be approximately one.

Multi-decadal Sedimentation - The core transect in the sound lacks a three dimensional aspect, so that a sediment budget cannot be estimated. The data do, however, provide the means to estimate any variability in temporal fluxes. On a decadal scale, comparison of the total inventory of the short live isotopes at a site with the inventory of atmospheric fluxes gives a glimpse of temporal sediment variability. The total isotopic inventory is 
an easily calculated parameter. Inventory is defined as the total amount of an isotope at a site and is calculated by:

$$
I \square \square\left(A_{d p m / g} * R h o g / \mathrm{cm} 3 * Z_{c m}\right)
$$

where $I$ is inventory $\left(\mathrm{dpm} / \mathrm{cm}^{2}\right) ; A_{\mathrm{dpm} / \mathrm{g}}$ is activity is dpm per gram; Rho is dry bulk density $\left(\mathrm{g} / \mathrm{cm}^{3}\right)$; and $Z$ is sample interval $(\mathrm{cm})$. The nominal time that inventory is useful is a function of the isotopic half-life and/or the time of introduction. With a $\sim 22$ years half life, ${ }^{210} \mathrm{~Pb}$, has an effective nominal limit of 100 years; with $\mathrm{a} \sim 30$ year half life and an introduction in 1950 's, the effective time limit for ${ }^{137} \mathrm{Cs}$ is 50 years. Since ${ }^{137} \mathrm{Cs}$ has been in the environment for $\sim 50$ years, for comparative purposes, the ${ }^{210} \mathrm{~Pb}$ inventory must be adjusted.

Because ${ }^{210} \mathrm{~Pb}$ is constantly being replenished, its inventory has been constant for over a millennia, varying only with the nuances of atmospheric circulation. The ${ }^{210} \mathrm{~Pb}$ inventory was determined to be $\sim 32 \mathrm{dpm} / \mathrm{cm}^{2}$ in New England (Cochran and others, 1998). Using the data from the Surface Air Sampling Program (SASPwww.eml.doe.gov/database/), it was determined that the ${ }^{210} \mathrm{~Pb}$ concentration at Sterling Virginia was $60 \%$ that of New England; thus it is estimated to be $\sim 19 \mathrm{dpm} \mathrm{cm}^{-2}$. Adjusting for the last fifty years, the inventory would be an estimated $16.0 \mathrm{dpm} \mathrm{cm}^{-2}$. Because most of the ${ }^{137} \mathrm{Cs}$ was added to the environment during a short period, 19591963, the inventory has decayed over time. The maximum ${ }^{137} \mathrm{Cs}$ inventory $9.2 \mathrm{dpm} \mathrm{cm}{ }^{-2}$ occurred during 1963 in the Chesapeake Bay region. Today, through decay, the inventory of this isotope is approximately $5 \mathrm{dpm} \mathrm{cm}^{-2}$.

The ${ }^{210} \mathrm{~Pb}$ inventory in cores $1,2,3$, and 4 are $10.0,16.6$, and $14.1 \mathrm{dpm} \mathrm{cm}^{-2}$ respectively (Appendix 2.2). As these values are very close to the estimated atmospheric inventory and there is no evidence of loss or disruption in the records for this period (figure 2.5), the sediment deposited on the Pocomoke delta for the last fifty years approximates equilibrium with the ${ }^{210} \mathrm{~Pb}$ atmospheric flux. The inventory on the Pocomoke tidal flat of $29.3 \mathrm{dpm} / \mathrm{cm}^{2}$, is almost twice the atmospheric inventory, where as core PC-6B has an estimated inventory of $150 \mathrm{dpm} / \mathrm{cm}^{2}$, approximately ten times the expected ${ }^{210} \mathrm{~Pb}$ estimated atmospheric inventory. 
${ }^{137} \mathrm{Cs}$ in cores 1,2 , and 3 have an estimated inventory of $1.5,2.2$, and $2.2(\mathrm{dpm}$ $\mathrm{cm}^{-2}$ ) respectively (Table 1 ). These values are about $20 \%$ of the expected inventory. However, Core 4, from the Pocomoke River tidal flat has an inventory of 11.4 (dpm cm ${ }^{2}$ ); about twice the estimated atmospheric inventory, and Core PC-6B has an inventory of $36.7\left(\mathrm{dpm} \mathrm{cm}^{-2}\right)$; about seven times the estimated atmospheric inventory.

Figure 2.12 is a plot of the atmospheric flux to core inventory ratios for all the cores. The ${ }^{210} \mathrm{~Pb}$ in cores 2 and 3 are very close to one whereas ${ }^{137} \mathrm{Cs}$ is much less. This suggests that the sediment that has been deposited on the delta for the last fifty years has a large "exhumed" fraction. This pattern seems to be evident in core 1, but the smaller ${ }^{210} \mathrm{~Pb}$ ratio is suggestive a higher content of older sediment. The inventory in cores 4 and 6 exceeds the expected inventory for both isotopes. The ${ }^{137} \mathrm{Cs}$ concentration is suggestive of a large contribution from the watershed and the large ${ }^{210} \mathrm{~Pb}$ concentration is suggestive of a sediment focusing. Together, this suggests that the tidal flats are storage areas for sediment eroded from the watershed.

The accumulation rates in all the cores but core PC-6B are relatively slow, and as a result the temporal resolution is poor. However, the rate of accumulation in core PC-6B is extremely high. As a result, this core illustrates many sedimentological changes that have occurred within the sound over the last fifty years. Figure 2.13 is a plot of the ${ }^{137} \mathrm{Cs}$ distribution. The figure includes the flux inventory at Sterling and the data from core 6 . The ${ }^{137} \mathrm{Cs}$ data is decay corrected and plotted as percent inventory $\left({ }^{137} \mathrm{Cs}\right.$ core $/{ }^{137} \mathrm{Cs}$ flux *100). The plot shows a slight increase at about 1963 which is assumed to be the result of maximum atmospheric production. The highest percentage occurred in 1968, with a flux of about 60 percent the atmospheric contribution. Between 1968 and 1971, the introduction of ${ }^{137} \mathrm{Cs}$ enriched sediment declined rapidly to about 20 percent. The only exception was the increase in 1972, which corresponds to the sediment derived from the flooding due to Hurricane Agnes. Nie and others (2001), and Helz and others (1985) also recognized this increase in the bay. After this event there is a significant drop off in enriched ${ }^{137}$ Cs sediment between 1973 and 1976. This drop off in sediment delivery is believed to be the result of sediment flushing of material that had been stored in temporary storage sites, in the case of the Pocomoke system on the tidal flats. This phenomenon has been recognized other places within the Bay (Nie and others, 2001) and 
elsewhere in other places within the country (Horowitz, 2003). Since 1976, there appears to be a steady flux of ${ }^{137} \mathrm{Cs}$ tagged sediment. The data suggests that this is about 20 percent the amount still in the watershed.

\section{Conclusions}

The goal of this project was use radionuclides to measure the sedimentary dynamics of Pocomoke Sound. Using the shortest-lived isotopes ${ }^{7} \mathrm{~B}$, the seasonal deposition centers were defined and the $\mathrm{A}_{\mathrm{T}(0)}$ for ${ }^{210} \mathrm{~Pb}$ was estimated and. Using the latter value and the ${ }^{210} \mathrm{~Pb}$ activity at depth in each core, sanitizing the data by best fitting procedures to a standard curve, a chronology for each core was calculated. This information was then used to examine, in detail, the ${ }^{137} \mathrm{Cs}$ distribution and the trace metal data. The results of this analysis showed that there has been a significant increase in anthropogenic elements since the late 1940's (Figure 2.14). This is the period when the Delmarva Peninsula became more accessible from the Baltimore-Washington metroplex. ${ }^{137} \mathrm{Cs}$, was found to be a useful tool in determining changes in sedimentation within the system. This data showed that there were three major stages of sedimentation. The pre1950 's, the time in which the system was equilibrium with the agriculture activity in the watershed. Urbanization and agricultural activity changed during and immediately following World War II resulting increasing sediment flux. Around 1970, the increased environmental awareness coupled with changes in agriculture (row crops to chickens), the sediment flux was diminished. Correspondingly, there was an apparent change in sources of sediment to the deeper parts of the system. The chemistry and sediment accumulation rates suggest that this source was bank erosion.

\section{Acknowledgements}

We would like to acknowledge Owen Bricker who helped improve the original manuscript significantly. Also we acknowledge Deb Willard, Tom Cronin, and others who assisted in the field and lab work. Also we acknowledge the dedication of Heather Kamanski who prepared the samples for $\square$ - analysis.

\section{References}


Carroll, J.L., Lerche, I., Abraham, J.D., and Cisar, D.J., 1995, Model-determinated sediment ages from ${ }^{210} \mathrm{~Pb}$ profiles in unmixed sediments, Nuclear Geophysicals, v.9, p.1791-1804.

Cochran, J.K., Hirschberg, D.J., Wang, J., and Dere, C., 1998, Atmospheric deposition of metals to Coastal waters, (long Island Sound, New York, U.S.A.): Evidence from Salt marsh deposits, Estuarine, Coastal and Shelf Science, v.46, p. 503-522.

Crusius J., and Thomson, J., 1996, Comparative behavior of authigenic Re, U, and Mo, during reoxidation and subsequent long-term burial in marines sediments, Geochemica and Cosmochemic Acta, vol. 64, pp. 2233-2242/

Edgington, D. and Robbins, J.A., 2000, Time dependant distribution of cs-137 in the sediment of Lake Michigan, Proceedings of SPERA conference, New Caldonia.

Faure, G, 1986, Principles of Isotope Geology, J. Wiley and Sons, N.Y., 589 pp.

Flynn, W. W., 1968. The determination of low levels of polonium-210 in environmental materials. Analytica Chimica Acta. 43: 221-227.

Helz, G.R., Setlock, G.H., Cantillo, A.Y., and Moore, W.S., 1985, Porcesses controlling the regional distribution of ${ }^{210} \mathrm{~Pb},{ }^{226} \mathrm{Ra}$, and anthropogenic zinc in estuarine sediments, Earth and Planetary Science Letters, v. 76, pp 23-34.

Horowitz, A.J., 2003, An evaluation of sediment rating curves for estimating suspended sediment concentrations for subsequent flux calculations, Hydrological Processes, v. 17 pp102-134.

Iivari, T.A., 1991, Effect of Choptank Watershed drainage project on suspended sediment concentrations, Irrigation and Drainage, Proceedings of National Conference, ASCE, Honolulu, Hi, 1991pp 223-230.

Morford, J.L, and Emerson, S., 1999, The geochemistry of redox sensitve trace metals in sediments, Geochemica et Cosmochemica Acta, V.63, pp 1735-1750.

Nie, Y., Suayah, L.B., and Benninger, L.K., 2001, Modeling detailed sedimentary $210 \mathrm{~Pb}$ and fallout 239,240 Pu profiles to allow episodic events: an Application in Chesapeake Bay, Limnology and Oceanography, v. 46, pp. 1425-1437.

Oldfield, F. and Appleby, P.G., 1984, Empirical testing of 210Pb-dating models for lake sediments, in Lake Sediments and Environmental History (ed. Haworth, E.Y., and Lund, J.W.G.), pp. 93-124, University of Minnesota, Minneapolis, Mn. 
Ritchie, J. and McHenry, J.R., 1990, Application of radioactive fallout cesium-137 for measuring soil erosion, and sediment accumulation rates and patterns, a review, Journal of Environmental Quality, v. 19, pp. 215-233.

Robbins, J.A., 1986, A model for particle-sediment transport of tracers in sediments with conveyor-belt deposit feeders, Journal of Geophysical Research, v.91, p. 85428558

Robbins, J.A., 1978 Geochemical and geophysical applications of radioactive lead isotopes. In Biogeochemistry of Lead (ed. Nriago, J.P.), pp. 285-393, North Holland, Amsterdam.

Robbins, J.S., Holmes, C.W., Halley, R., Bothner, M.,Shinn, E., Graney, J., Keeler, G., ten Brink, M., Orlandini, K.A., and Rudnick, D., 2001, Time-averaged fluxes of lead and fallout radionuclides to sediment of Florida Bay, Journal of Geophysical research, v.105, pp 28,805-28,821.

Urban, N R, Eisenreich, S J; Grigal, D F; Schurr, K T. 1990, Mobility and diagenesis of $\mathrm{Pb}$ and ${ }^{210} \mathrm{~Pb}$ in peat, Geochimica et Cosmochimica Acta, vol.54, no.12, pp.3329-3346,

Van Straaten, L M J U; Kuenen, Ph H, 1958, Tidal action as a cause of clay accumulation, Journal of Sedimentary Petrology, vol.28, no.4, pp.406-413

Zimmerman, A.R., and Canuel, E.A., 2000, A geochemical record of eutropication and anoxia in Chesapeake Bay Sediments: anthropogenic influence on organic matter composition., Marine Chemistry, v. 69, pp 117-137. 


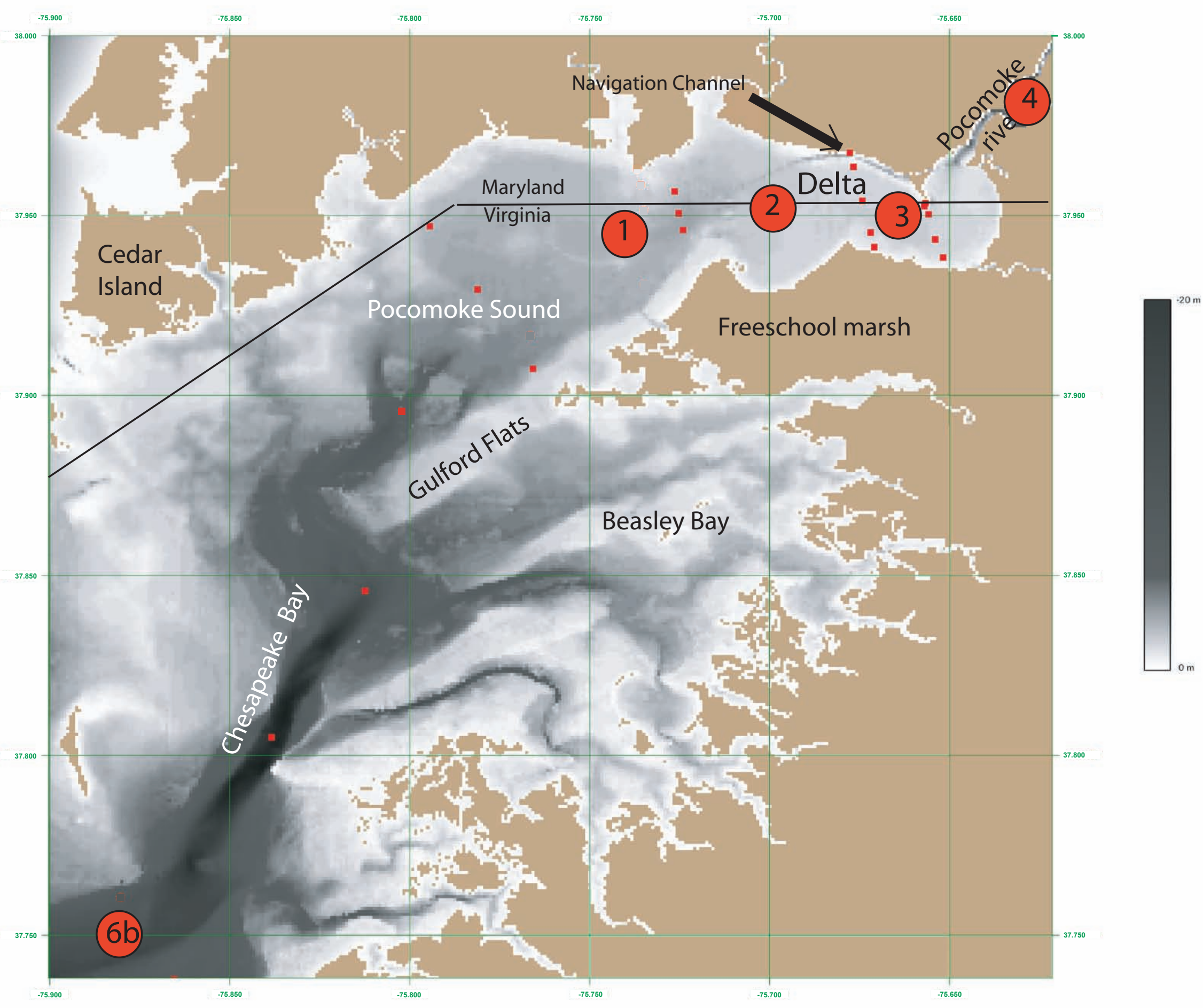

Figure 2.1 -- Bathymetric map of the Pocomoke Sound. Large circles are the location of cores. Small circles are location of surface samples. The bathymetry is represented by the tones of gray, with the darker gray being the deepest portion. 


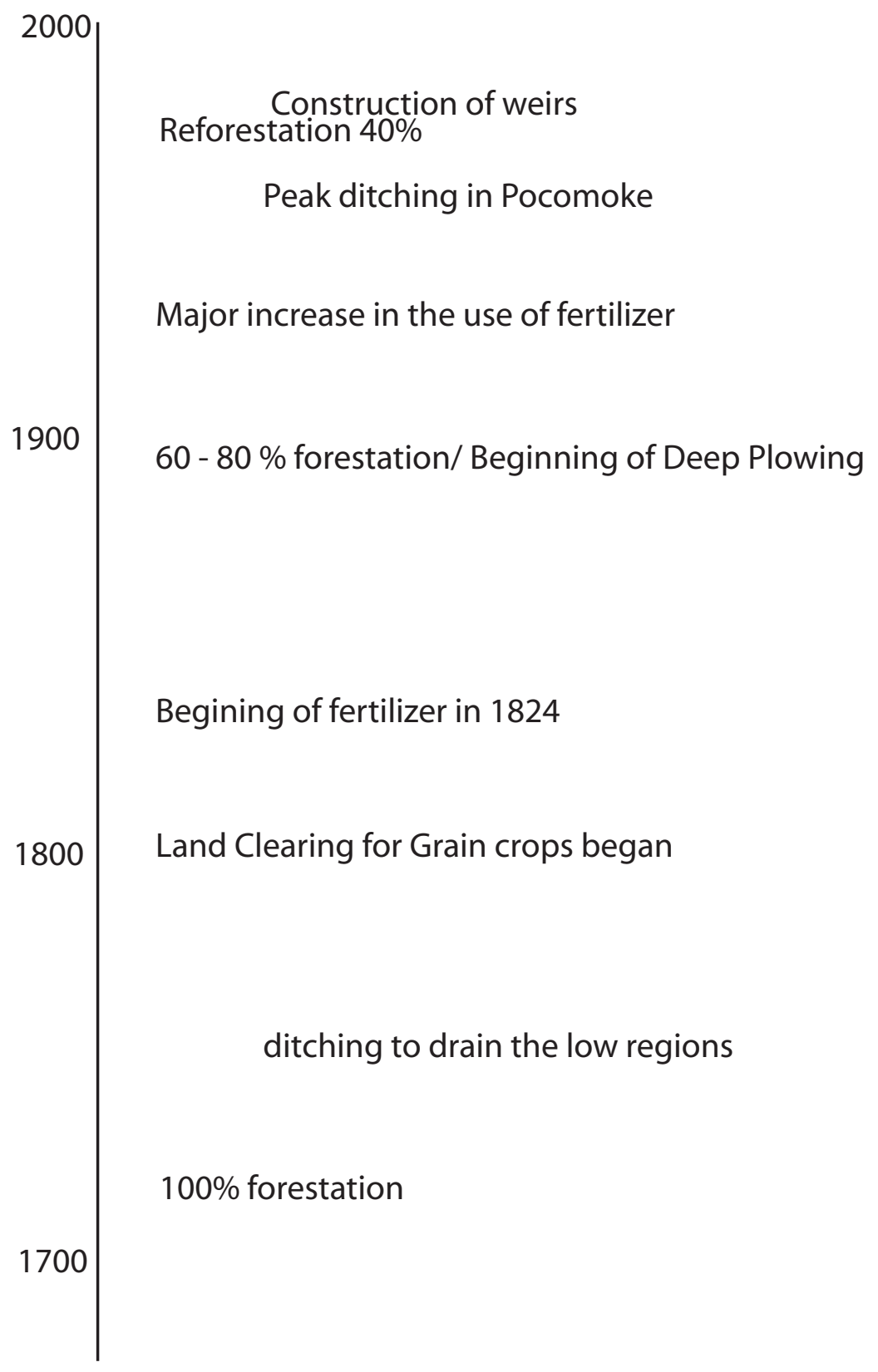

Figure 2.2 -- Timeline of major events that have affected sediment delivery to Pocomoke Sound (Zimmerman and Canuel, 2002) 


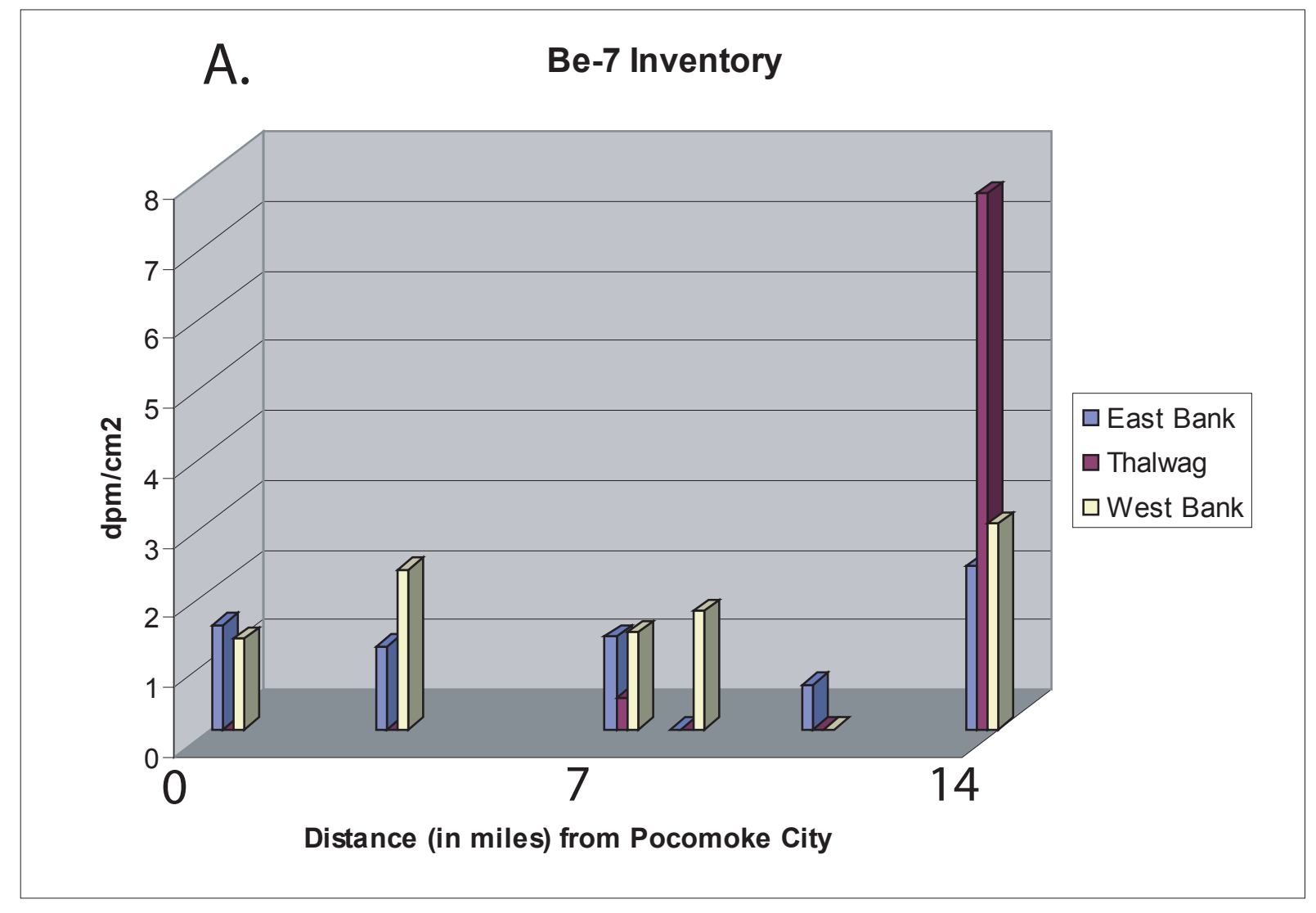

\section{B. Cs-137 Inventory (top $5 \mathrm{~cm}$ )}

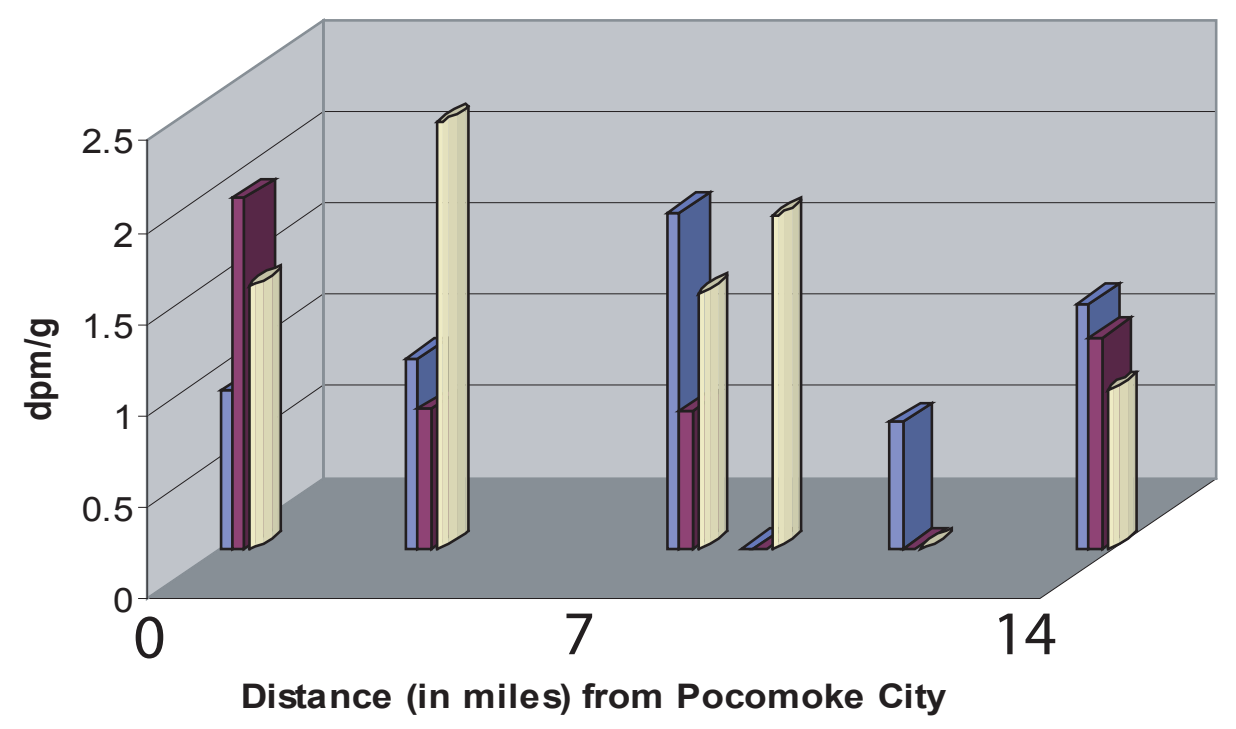

Figure 2.3 A. Distribution of ${ }^{7} \mathrm{Be}$ along the Pocomoke River from Pocomoke City to the mouth of the river. With the exception of the site at mile 13 , there is no ${ }^{7} \mathrm{Be}$ in sediment on the river bottom, only on the adjacent tidal flats. The highest ${ }^{7} \mathrm{Be}$ concentration occurs in the sediments of the river mouth delta. This concentration mirrors that of suspended sediment sampled in August, 2001. B. ${ }^{137}$ Cs distribution along the Pocomoke River. There is a significant amount of ${ }^{137} \mathrm{Cs}$ stored in this system. 

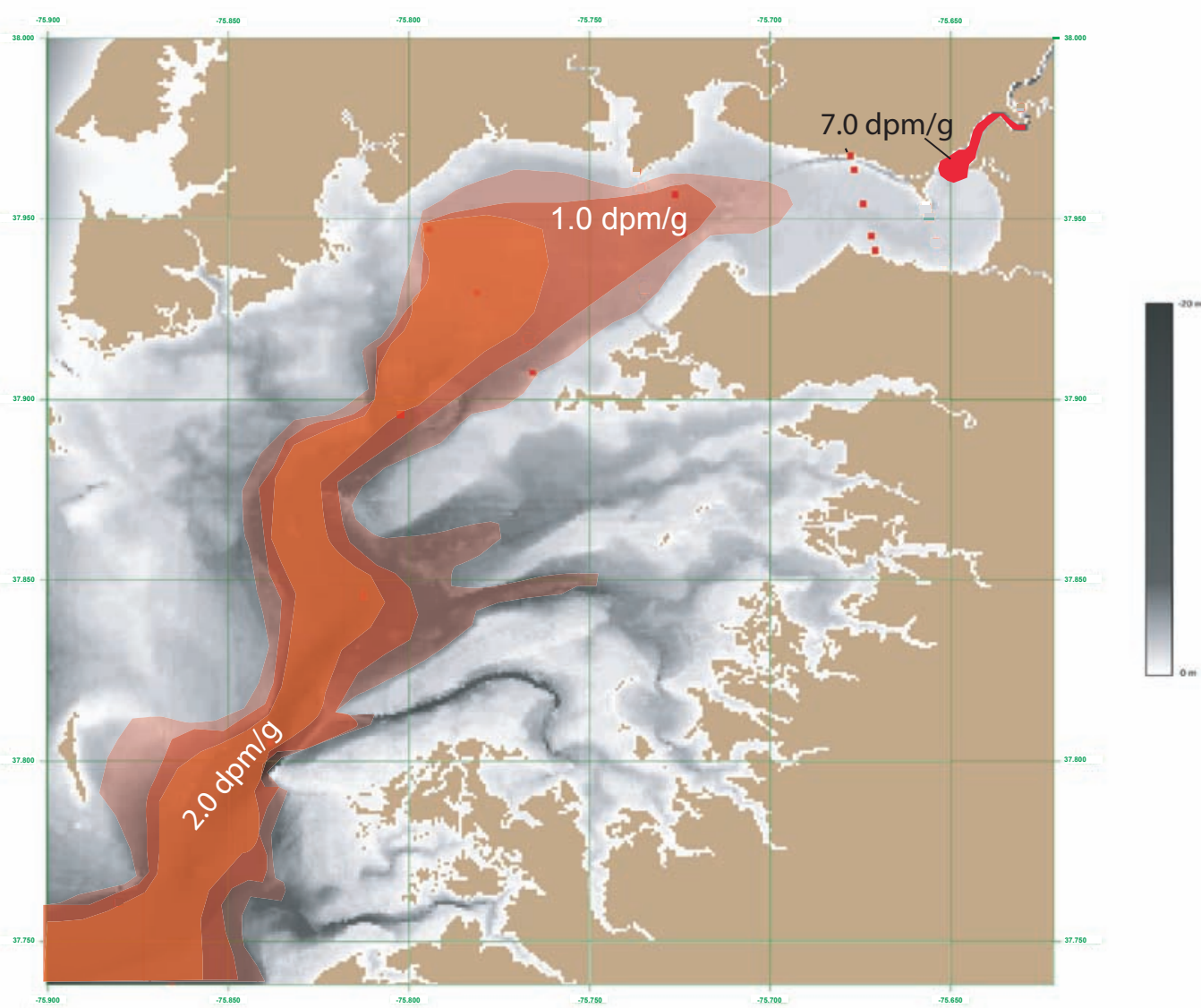

Figure 2.4a -- Trend of Be activity in Spring (May) samples.

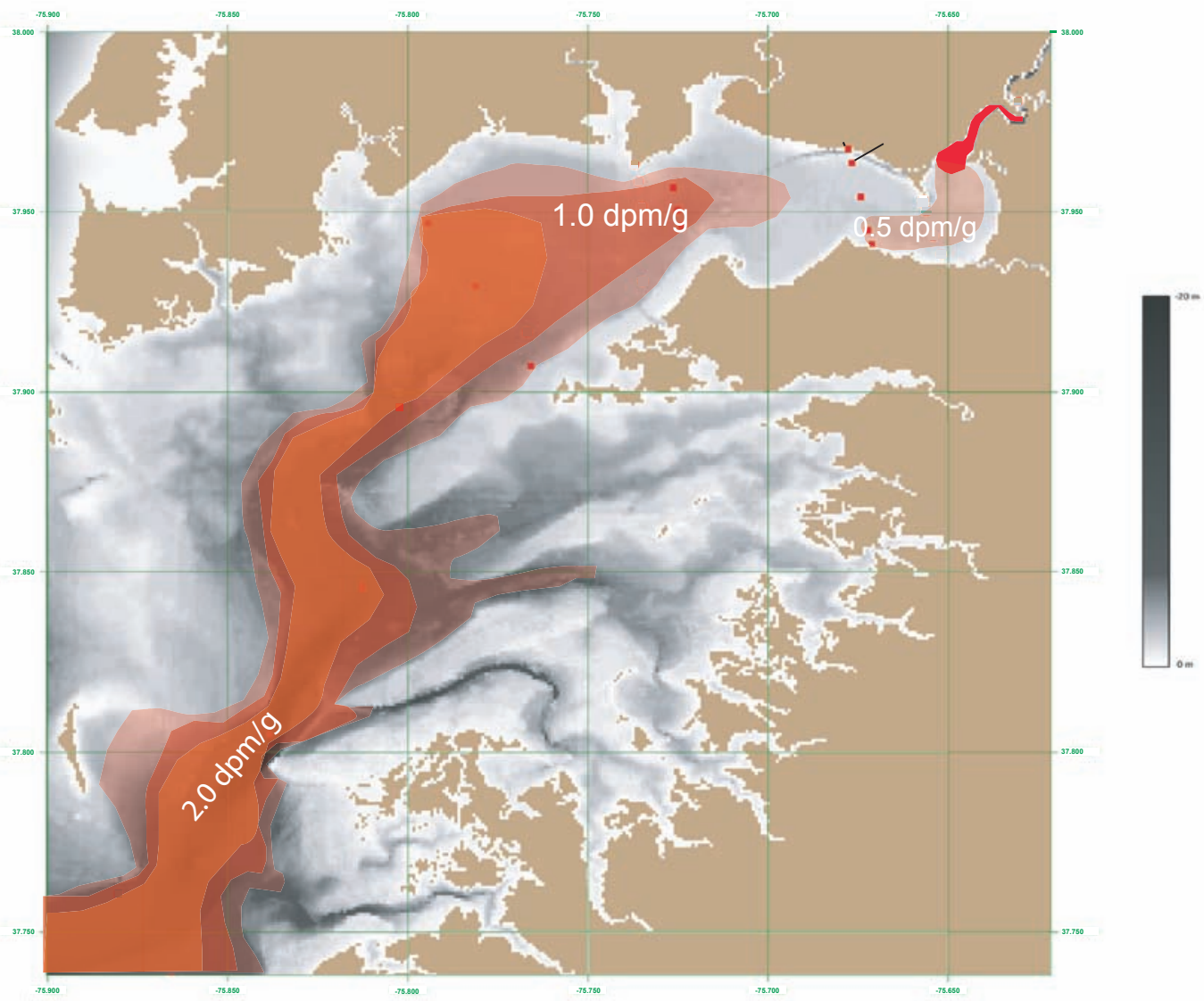

Figure $2.4 \mathrm{~b}$-- Trend of Be activity in fall ( September) samples.

Figure 2.4 -- The season trend of 7Be in the surface of Pocomoke Sound. A-Spring, B - Fall. The only seasonal difference is the larger presences of $7 \mathrm{Be}$ on the river side of the delta during the fall. 


\section{Pocomoke Sound Cores}

Core 1

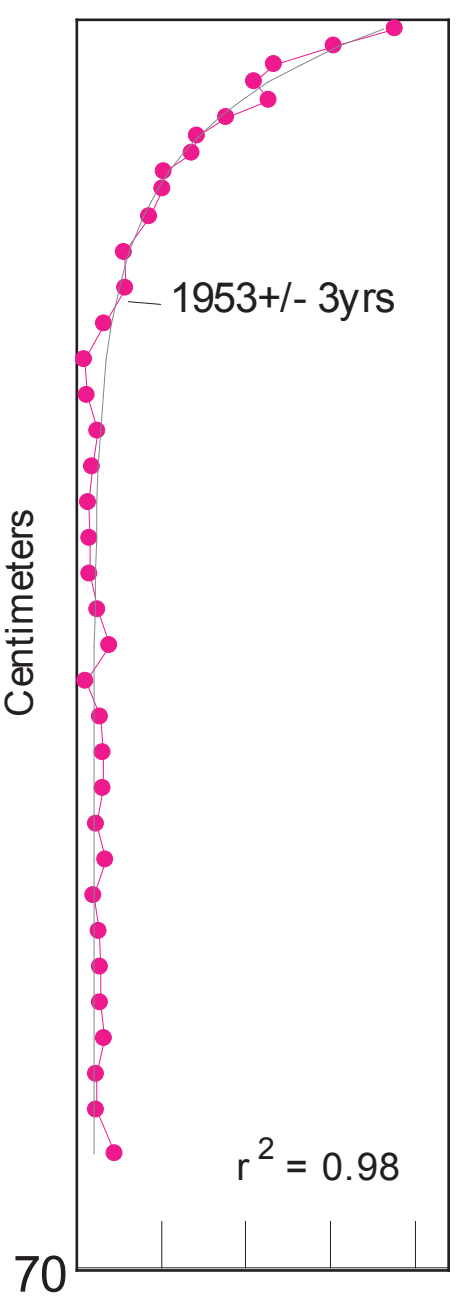

Core 2

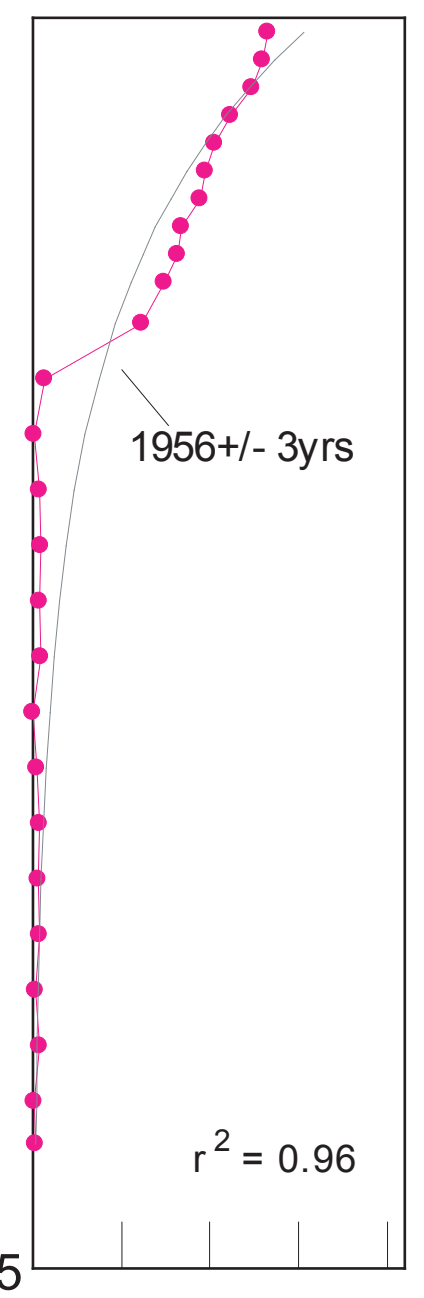

Core 3

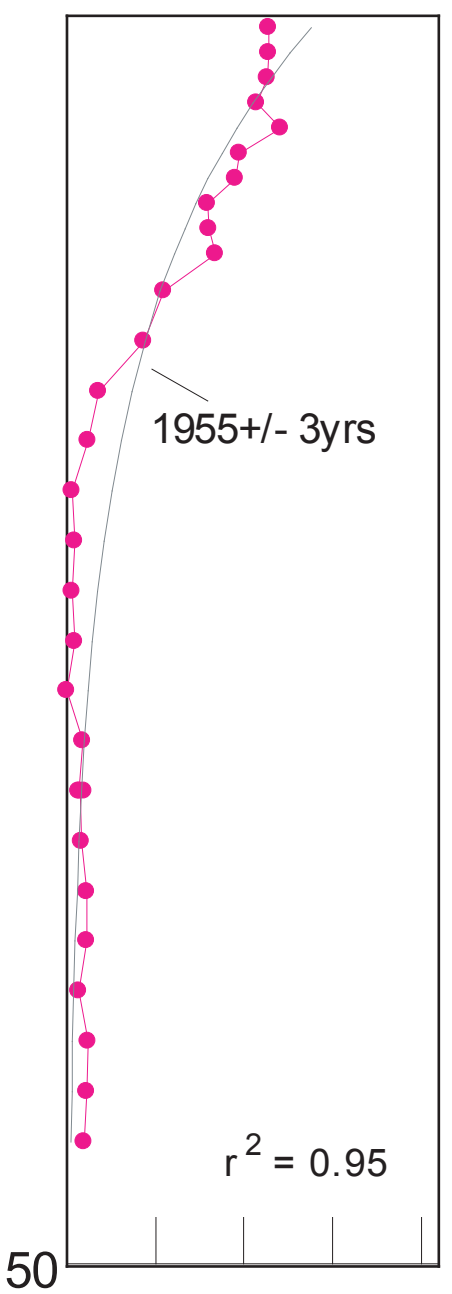

Core 4

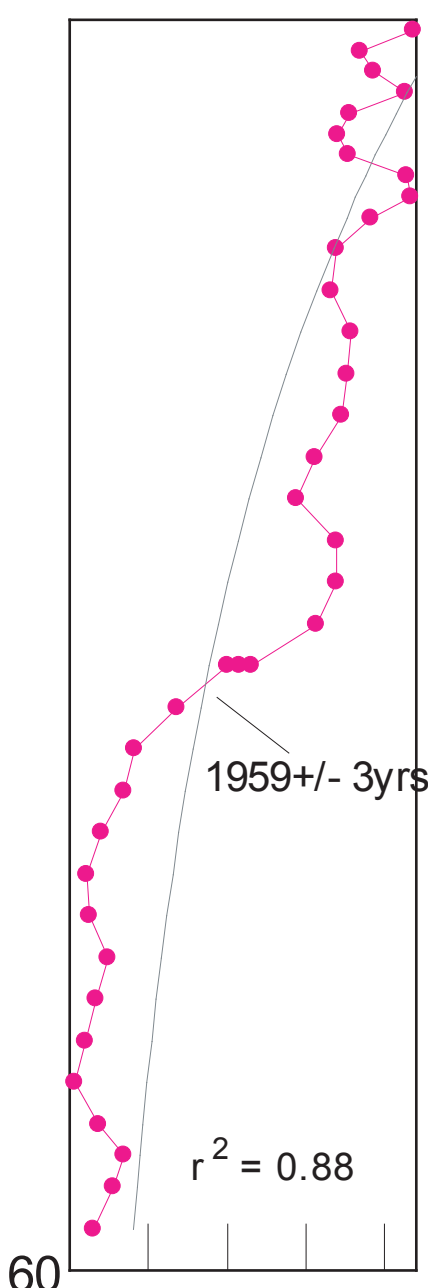

60

Core $6 b$

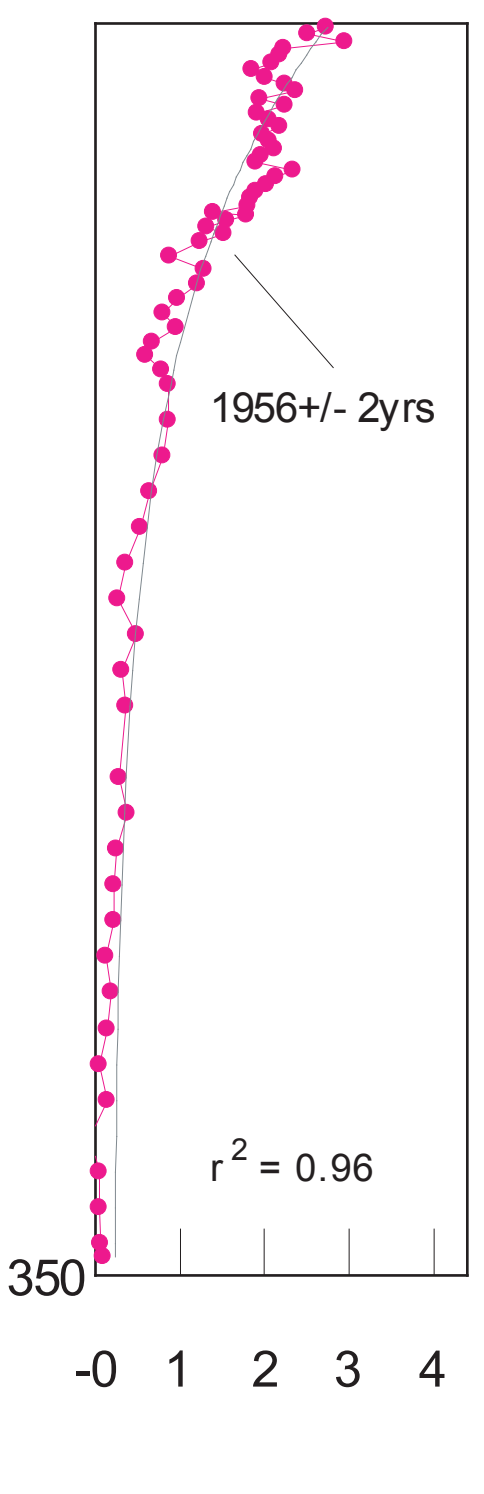

Figure 2.5 -- Excess 210Pb versus depth in the Pocomoke Sound cores. Core 1, on the seaward side of the delta is close to ideal. Cores 2,3,4, and 6 have what appears to have two different $210 \mathrm{~Pb}$ distributions. In the upper part of the cores, the $210 \mathrm{~Pb}$ decrease is not as great as it is with depth. This suggests the sediment in the upper part of the cores was being deposited at a greater rate than those deeper in the section. 


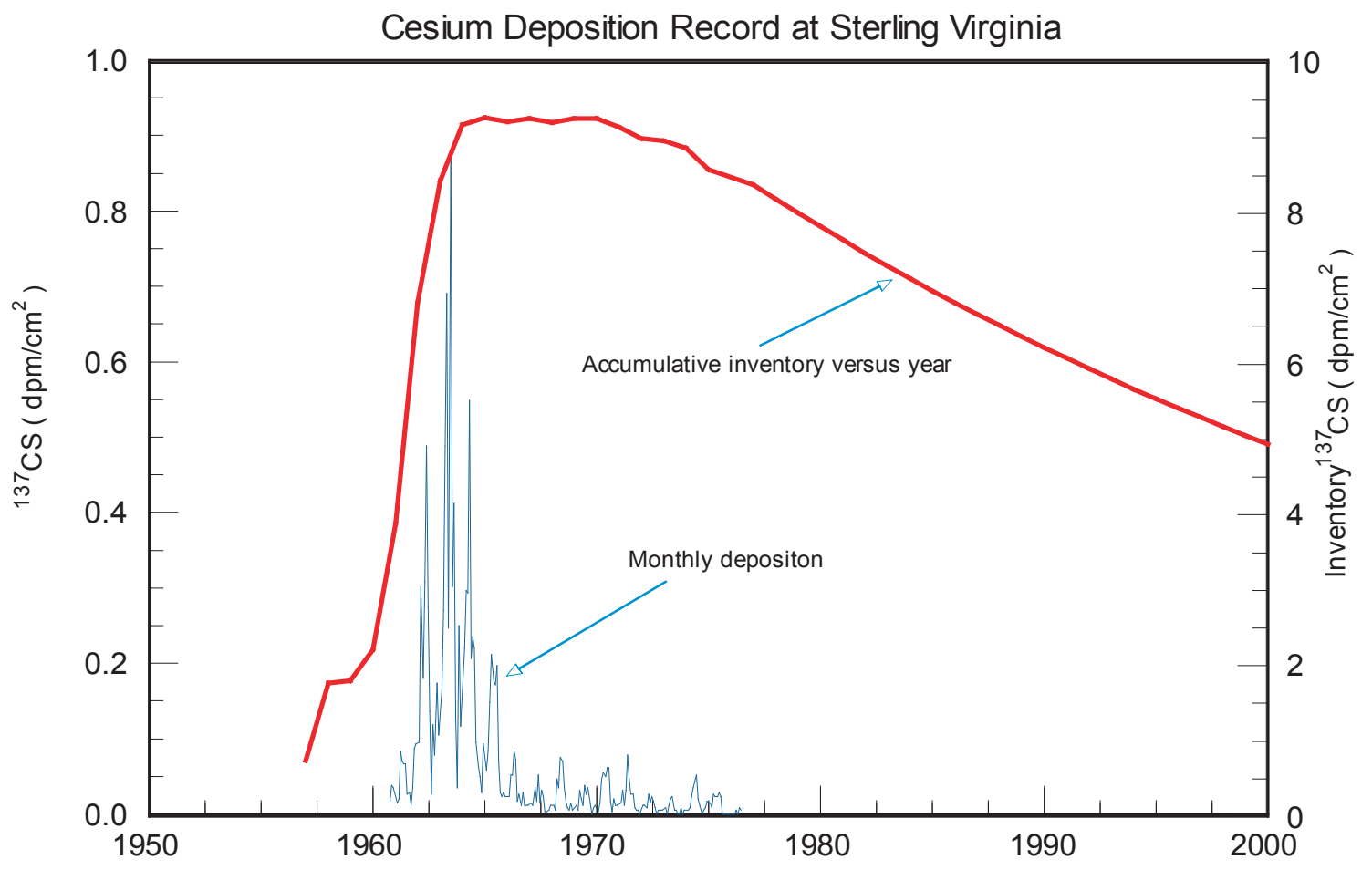

Figure 2.6 -- The monthly and accumulation ${ }^{137}$ Cs record at Sterling Va. The data were calcalculated from Sr-90 record and corrected with the production ratio between Sr-90 and Cs-137 as recorded at Sterling (www@eml.doe.gov/databases/) 


\section{${ }^{137}$ Cs in cores from Pocomoke Sound}

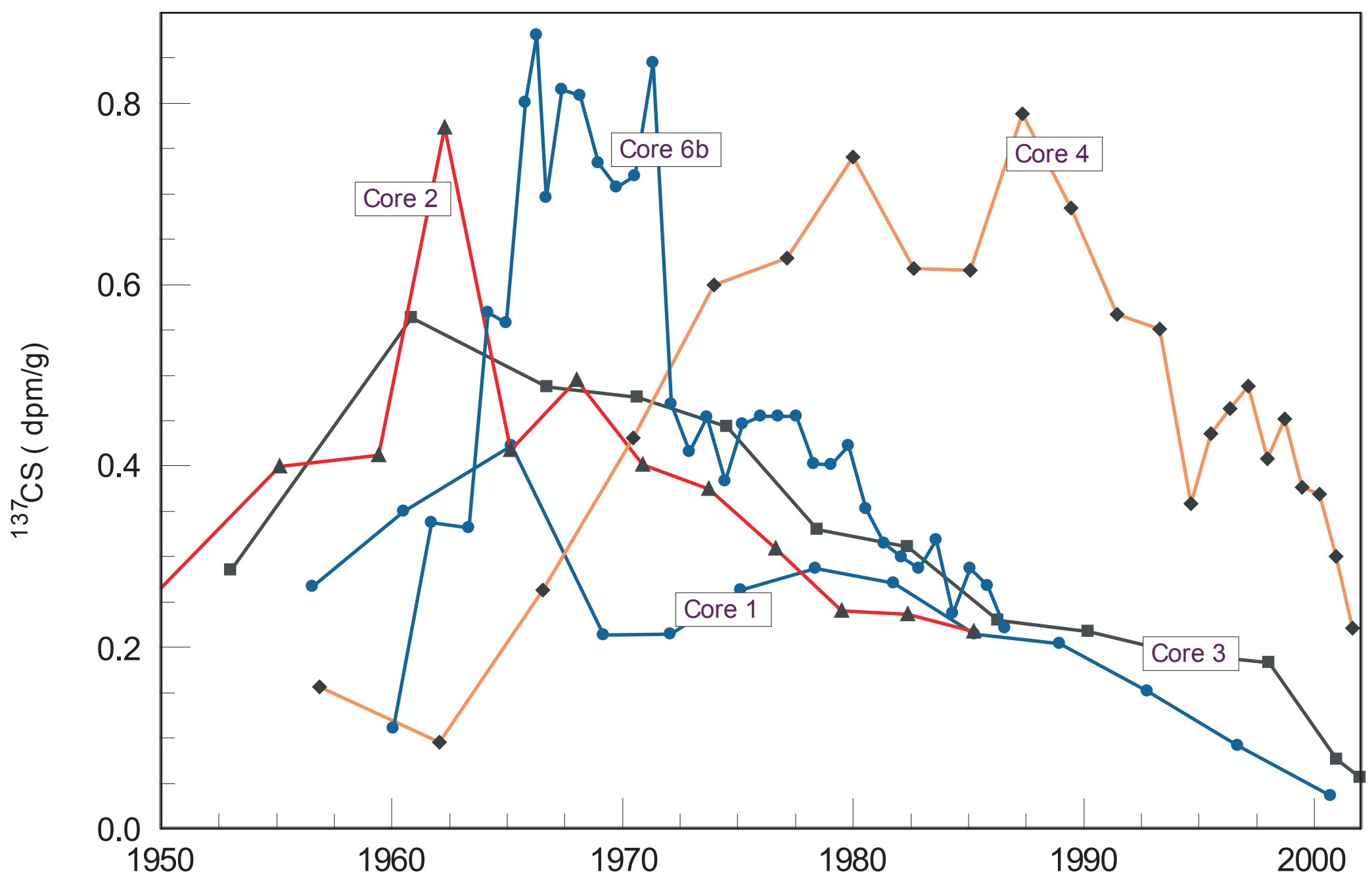

Figure 2.7 -- The distribution of ${ }^{137} \mathrm{Cs}$ in the cores from the Sound. The ${ }^{137} \mathrm{Cs}$ in cores 1,2 , and 3 are nominal well defined $1962-1963$ peak. There is no defined 1962-1963 peak in core 4. In core 4 the 137Cs increases to an apparent maximum around 1980, then has slightly decreased. The decrease coincides with the installation of weirs (livari, 1991). The concentrations in core 6 are significantly more than the shallower sites. In this core, there is no clear $1962-1963$ peak, there is however, a peak with a ${ }^{210} \mathrm{~Pb}$ age of 1967 . Also there is a peak at 1972 , which coincides with the Floods from Hurricane Agnes. After this event there is a significant decline in ${ }^{137} \mathrm{Cs}$ enriched sediment. 


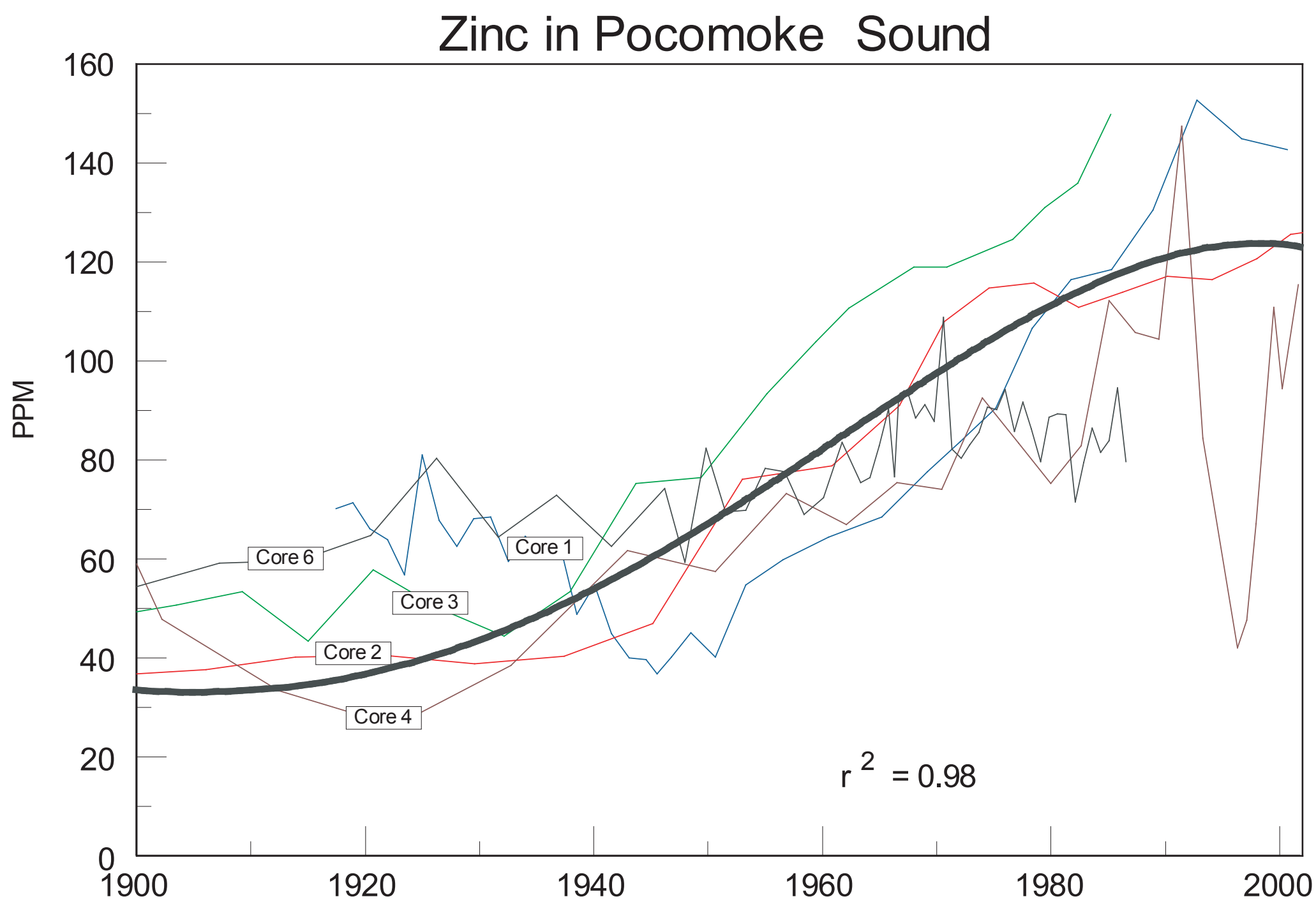

Figure 2.8 - The zinc concentrations of individual cores compared to the ${ }^{210} \mathrm{~Pb}$ chronology. Prior to 1940 the zinc concentrations in the sound varied from 30 to 60 pip. The concentration increased to maximum of greater than 100 ppm in the mid 1970's and has held fairly constant from 1980 to the present. 
Core 1- Pocomoke Sound

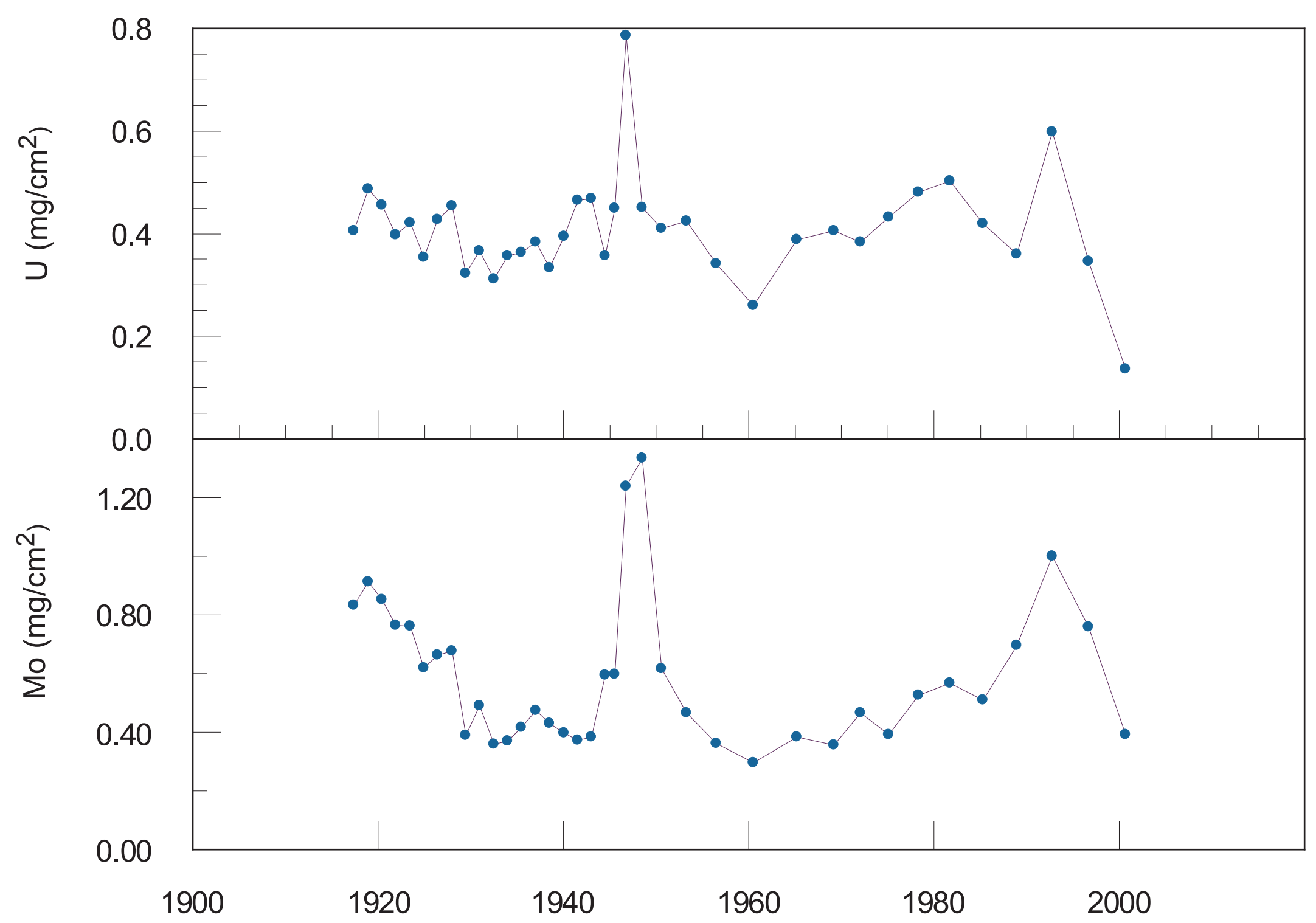

Figure 2.9 - A plot of uranium and molybdenum is the sediments of Pocomoke Sound. The 1950 and the 1995 peaks suggests that these were times when the bottom water were anoxic or near anoxic. 


\section{Chesapeake Bay Core 6B}

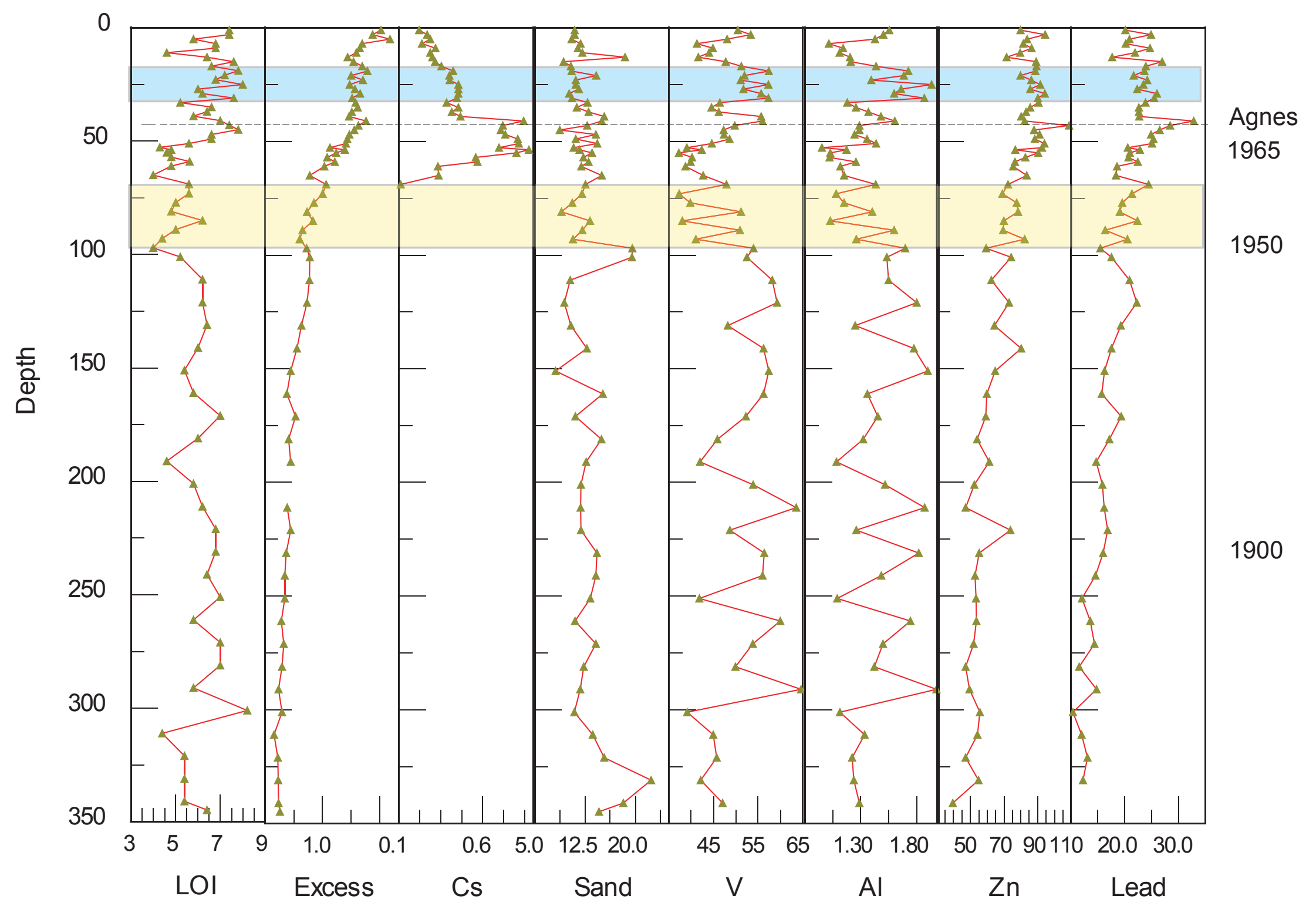

Figure 2.10 - Plot of the organic carbon index (LOI), short lived isotopes, texture and selected elements for core 6 . It is note worth that between 1950 and 1965, there was a decrease in aluminum, vanadium, and loss on ignition. During this period the zinc and lead began to increase. One feature of note is that during the flood that accompanied Hurricane Agnes, there is an increase in all substances. 


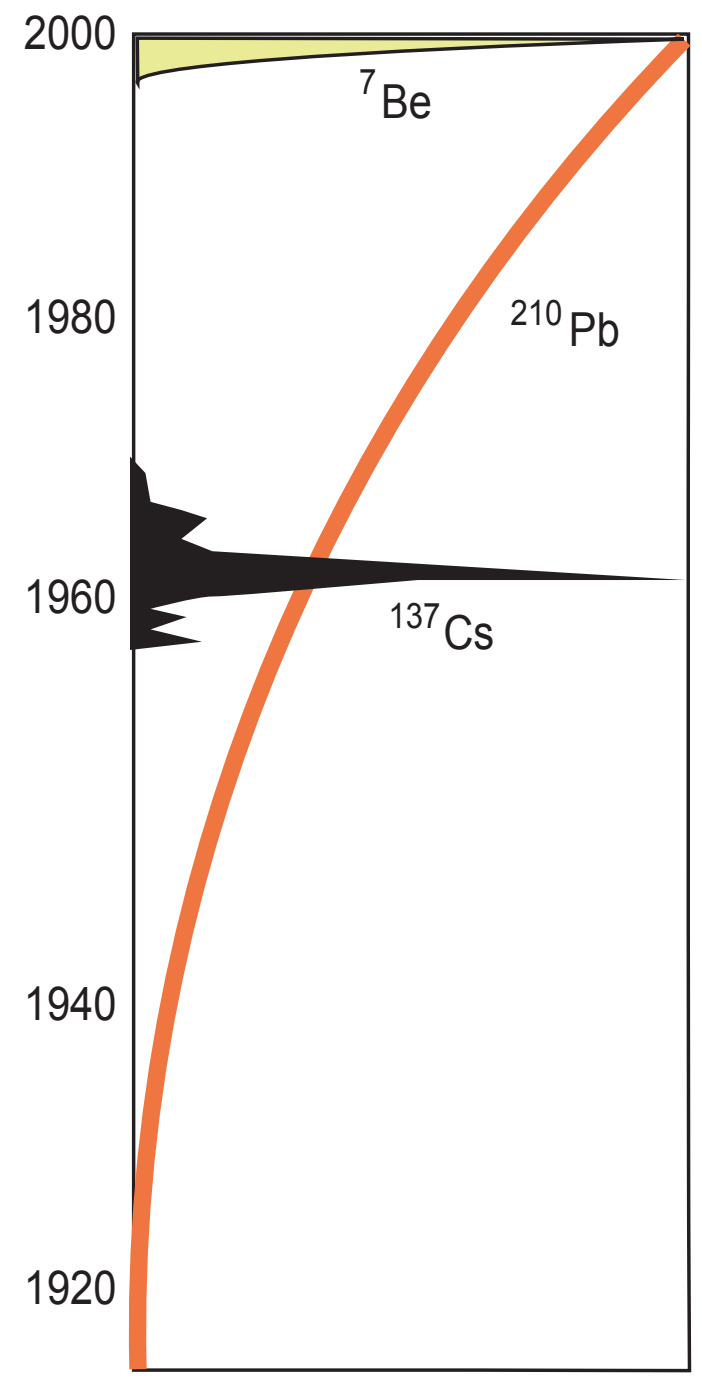

Steady State

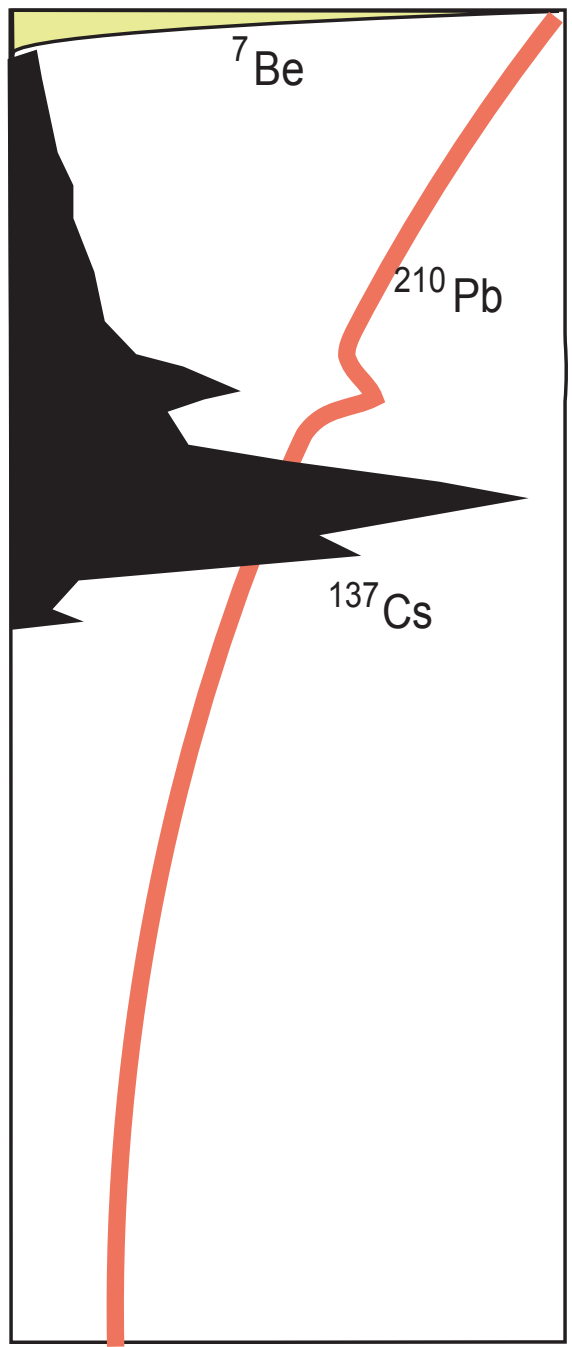

Watershed sediment

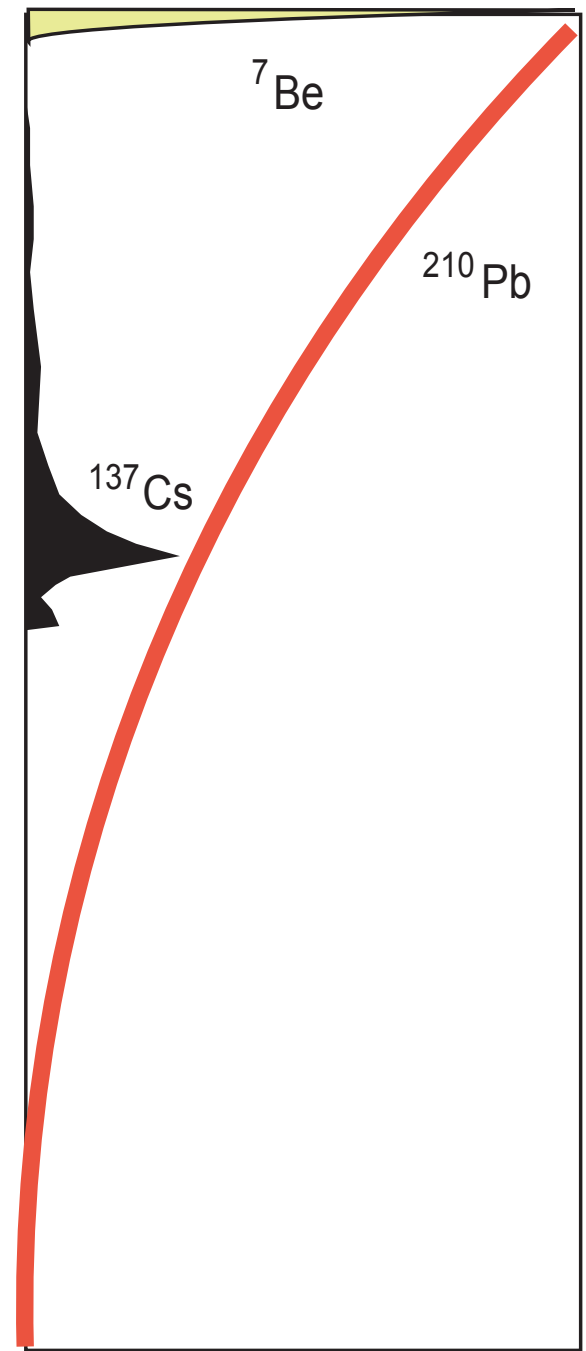

Exhumed sediment

Figure 2.11 -- Dynamic models; a.) the ideal case where the ${ }^{137} \mathrm{Cs}$ and ${ }^{210} \mathrm{~Pb}$ deposited from within the basin. b). the case where a significant amount of sediment is derived from the surface of the watershed. c). The case where most of the sediment is exhumed from region that was not at the surface during the $1955-1970$ period when ${ }^{137}$ Cs was being deposited. 


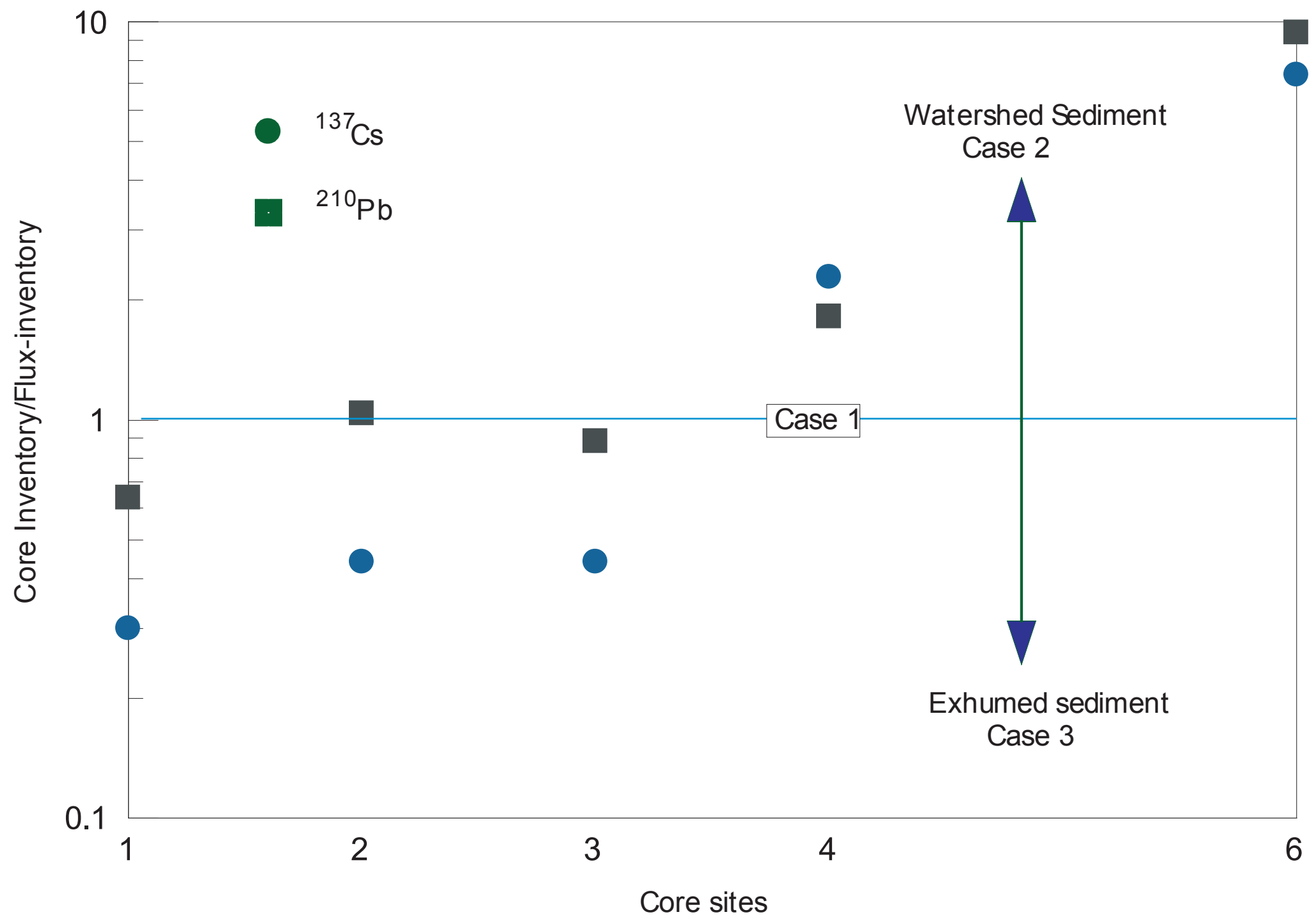

Figure 2.12 - Flux ratios (sum of the core inventory/sum of the flux inventory for ${ }^{137} \mathrm{Cs}$ (circles) and ${ }^{210} \mathrm{~Pb}$ (squares) for the individual cores. 


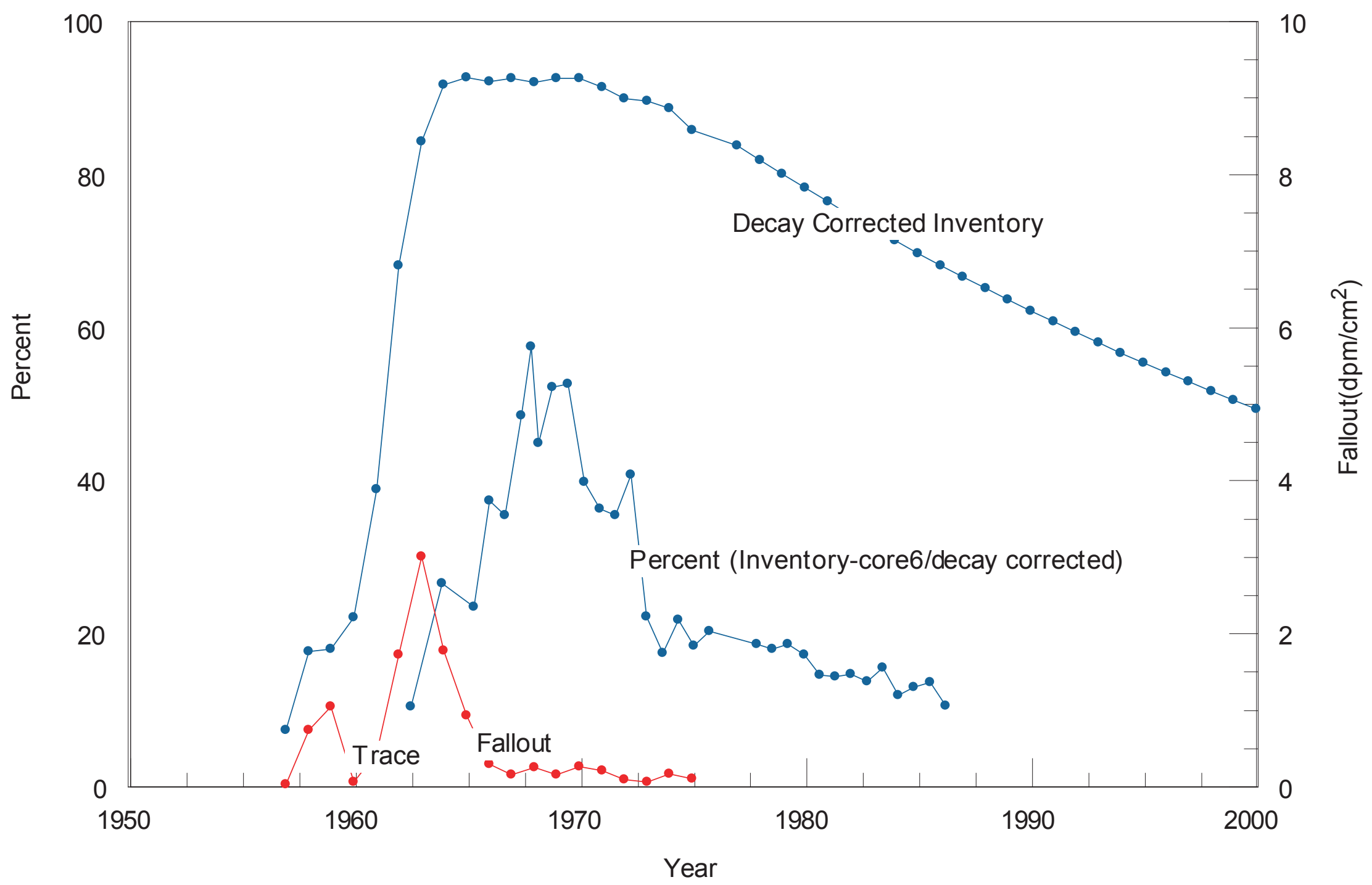

Figure 2.13 - Comparison between the fluxes of ${ }^{137} \mathrm{Cs}$ sediment to the percent flux at Sterling Virginia for core 6 . This graph demonstrated that there was a significant contribution of sediment from the watershed prior to 1972. After this time, maybe as a result of flushing due to the flooding caused by Hurricane Agnes, the sediment regime apparent changes with much less sediment now being derived from the watershed. 


\section{Generalized Distribution of Trace Metals in Pocomoke Sound}

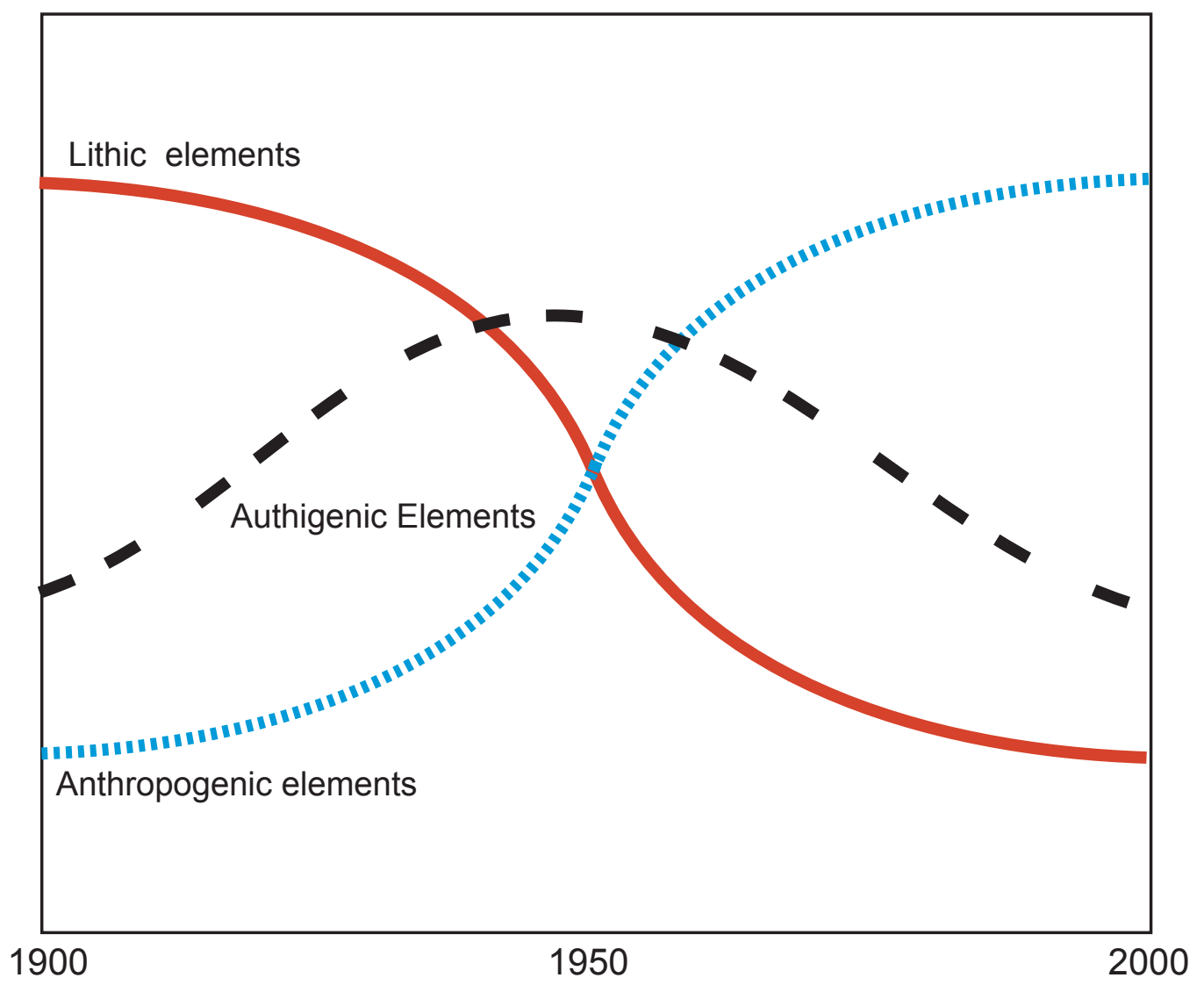

Figure 2.14 - Summary of trace metal history delivery to the basin over the last 100 years. 
Table 2.1—Radionuclide inventory in the cores from Pocomoke Sound

\begin{tabular}{|c|c|c|c|}
\hline & $\begin{array}{c}{ }^{137} \mathrm{Cs} \\
\mathrm{dpm} \mathrm{cm}^{-2} \\
(\text { since } 1960)\end{array}$ & $\begin{array}{c}{ }^{210} \mathrm{~Pb}_{\mathrm{cs}} \\
\mathrm{dpm} \mathrm{\textrm {cm } ^ { - 2 }} \\
(\text { since } 1960)\end{array}$ & $\begin{array}{c}{ }^{210} \mathrm{~Pb}_{\text {total }} \\
\mathrm{dpm} \mathrm{cm}^{-2}\end{array}$ \\
\hline Atmosphere & 5 & 16 & 19 \\
\hline Core 1 & 1.5 & 10.2 & 10.9 \\
\hline Core 2 & 2.2 & 16.6 & 17.4 \\
\hline Core 3 & 2.2 & 14.1 & 16.1 \\
\hline Core 4 & 11.4 & 29.3 & 31.6 \\
\hline Core 6 & 36.7 & 150 & 200.7 \\
\hline & & & \\
\hline
\end{tabular}


Table 2.2. Method for ultratrace elemental analyses

A $0.5 \mathrm{~g}$ sample is digested in aqua regia at $90^{\circ} \mathrm{C}$ in a microprocessor controlled digestion box for 2 hours. The solution is diluted and analyzed by ICP/MS using a Perkin Elmer SCIEX ELAN 6100. International certified reference materials USGS GXR-1, GXR-2, GXR-4 and GXR-6 are analyzed at the beginning and end of each batch of samples.

Internal control standards are analyzed every 10 samples and a duplicate is run for every 10 samples.

Code Ultratrace-1 Elements and Detection Limits (ppm)

\begin{tabular}{|c|c|c|}
\hline Element & Detection Limit & Upper Limit \\
\hline $\mathrm{Au}^{*}$ & $0.2 \mathrm{ppb}$ & $20,000 \mathrm{ppb}$ \\
\hline $\mathrm{Ag}^{*}$ & 0.05 & 200 \\
\hline $\mathrm{Cu}$ & 0.1 & 10,000 \\
\hline $\mathrm{Cd}$ & 0.1 & 200 \\
\hline $\mathrm{Mn}^{*}$ & 1 & 10,000 \\
\hline Mo & 0.01 & 1,000 \\
\hline $\mathrm{Pb}^{*}$ & 0.01 & 1,000 \\
\hline $\mathrm{Ni}^{*}$ & 0.1 & 5,000 \\
\hline $\mathrm{Zn*}$ & 0.1 & 10,000 \\
\hline $\mathrm{As}^{*}$ & 0.1 & 10,000 \\
\hline $\mathrm{B}^{*}$ & 1 & 5,000 \\
\hline $\mathrm{Ba}^{*}$ & 0.5 & 6,000 \\
\hline $\mathrm{Sb}$ & 0.02 & 500 \\
\hline $\mathrm{W}^{*}$ & 0.2 & 200 \\
\hline $\mathrm{Al}^{*}$ & $0.01 \%$ & $10 \%$ \\
\hline $\mathrm{Be}^{*}$ & 0.1 & 1,000 \\
\hline $\mathrm{Bi}$ & 0.02 & 2,000 \\
\hline $\mathrm{Ca}^{*}$ & $0.01 \%$ & $50 \%$ \\
\hline $\mathrm{Ce}^{*}$ & 0.01 & 200 \\
\hline Co & 0.1 & 500 \\
\hline $\mathrm{Cr}^{*}$ & 0.5 & 500 \\
\hline $\mathrm{Cs}^{*}$ & 0.1 & 100 \\
\hline $\mathrm{Eu}^{*}$ & 0.1 & 100 \\
\hline $\mathrm{Fe}^{*}$ & $0.01 \%$ & $50 \%$ \\
\hline $\mathrm{Ga}^{*}$ & 0.02 & 500 \\
\hline $\mathrm{Ge}^{*}$ & 0.1 & 500 \\
\hline $\mathrm{Hf} *$ & 0.1 & 500 \\
\hline In & 0.02 & 100 \\
\hline $\mathrm{K}^{*}$ & $0.01 \%$ & 5 \\
\hline $\mathrm{La}^{*}$ & 0.5 & 200 \\
\hline $\mathrm{Li}$ & 0.5 & 1,000 \\
\hline $\mathrm{Lu}^{*}$ & 0.1 & 100 \\
\hline $\mathrm{Mg}^{*}$ & $0.01 \%$ & $10 \%$ \\
\hline $\mathrm{Na}^{*}$ & $0.001 \%$ & $1 \%$ \\
\hline $\mathrm{Nb}^{*}$ & 0.1 & 500 \\
\hline $\mathrm{Nd}^{*}$ & 0.1 & 200 \\
\hline $\mathrm{Rb}^{*}$ & 0.1 & 500 \\
\hline
\end{tabular}




\begin{tabular}{|c|c|c|}
\hline $\mathrm{Re}$ & 0.001 & 100 \\
\hline $\mathrm{Se}$ & 0.1 & 1,000 \\
\hline $\mathrm{Sm}^{*}$ & 0.1 & 100 \\
\hline $\mathrm{Sn}^{*}$ & 0.05 & 200 \\
\hline $\mathrm{Sr}^{*}$ & 0.5 & 1,000 \\
\hline $\mathrm{Ta}^{*}$ & 0.05 & 50 \\
\hline $\mathrm{Tb}^{*}$ & 0.1 & 100 \\
\hline $\mathrm{Te}$ & 0.02 & 500 \\
\hline $\mathrm{Th}^{*}$ & 0.1 & 200 \\
\hline $\mathrm{Tl}^{*}$ & 0.02 & 500 \\
\hline $\mathrm{U}^{*}$ & 0.1 & 200 \\
\hline $\mathrm{V}^{*}$ & 1 & 1,000 \\
\hline $\mathrm{Y}^{*}$ & 0.1 & 500 \\
\hline $\mathrm{Yb}^{*}$ & 0.1 & 200 \\
\hline $\mathrm{Zr}^{*}$ & 0.1 & 5,000 \\
\hline
\end{tabular}

$0.5 \mathrm{~g}$ of sample is digested with aqua regia $\left(0.5 \mathrm{ml} \mathrm{H} \mathrm{H}_{2} 0,0.6 \mathrm{ml}\right.$ concentrated $\mathrm{HNO}_{3}$ and $1.8 \mathrm{ml}$ concentrated $\mathrm{HCl}$ ) for 2 hours at $95^{\circ} \mathrm{C}$. Sample is cooled then diluted to $10 \mathrm{ml}$ with deionized water and homogenized. The samples are then analyzed using a Perkin Elmer OPTIMA 3000 Radial ICP for the 37 element suite. A matrix standard and blank are run every 13 samples.

A series of USGS-geochemical standards are used as controls. This digestion is near total for base metals however will only be partial for silicates and oxides.

Code 1E2 Elements and Detection Limits (ppm)

\begin{tabular}{|c|c|c|}
\hline Element & Detection Limit & Upper Limit \\
\hline $\mathrm{Ag}^{*}$ & 0.1 & 100 \\
\hline $\mathrm{Al}^{*}$ & $0.01 \%$ & \\
\hline $\mathrm{As}^{*}$ & 3 & \\
\hline $\mathrm{B}^{*}$ & 5 & \\
\hline $\mathrm{Ba}^{*}$ & 1 & \\
\hline $\mathrm{Be}^{*}$ & 1 & \\
\hline $\mathrm{Bi}^{*}$ & 2 & \\
\hline $\mathrm{Ca}^{*}$ & $0.01 \%$ & \\
\hline $\mathrm{Cd}$ & 0.2 & 2,000 \\
\hline $\mathrm{Co}^{*}$ & 1 & \\
\hline $\mathrm{Cr}^{*}$ & 2 & \\
\hline $\mathrm{Cu}$ & 1 & 10,000 \\
\hline $\mathrm{Fe}^{*}$ & $0.01 \%$ & \\
\hline $\mathrm{Hg}$ & 1 & \\
\hline $\mathrm{K}^{*}$ & $0.01 \%$ & \\
\hline $\mathrm{La}^{*}$ & 1 & \\
\hline $\mathrm{Mg}^{*}$ & $0.01 \%$ & \\
\hline $\mathrm{Mn}^{*}$ & 1 & 10,000 \\
\hline Mo* & 2 & 10,000 \\
\hline $\mathrm{Na}^{*}$ & $0.001 \%$ & \\
\hline $\mathrm{Ni}^{*}$ & 1 & 10,000 \\
\hline $\mathrm{P}^{*}$ & $0.001 \%$ & \\
\hline $\mathrm{Pb}^{*}$ & 2 & 5,000 \\
\hline $\mathrm{S}^{*}$ & $0.001 \%$ & $20 \%$ \\
\hline
\end{tabular}




\begin{tabular}{|c|c|c|}
\hline $\mathrm{Sb}^{*}$ & 5 & \\
\hline $\mathrm{Sc}^{*}$ & 0.1 & \\
\hline $\mathrm{Sn}^{*}$ & 5 & \\
\hline $\mathrm{Sr}^{*}$ & 1 & \\
\hline $\mathrm{Te}$ & 1 & \\
\hline $\mathrm{Ti}^{*}$ & $0.01 \%$ & \\
\hline $\mathrm{Tl}^{*}$ & 2 & \\
\hline $\mathrm{V}^{*}$ & 1 & \\
\hline $\mathrm{W}^{*}$ & 1 & 10,000 \\
\hline $\mathrm{Y}^{*}$ & 1 & \\
\hline $\mathrm{Zn}^{*}$ & 1 & \\
\hline $\mathrm{Zr}^{*}$ & 1 & \\
\hline
\end{tabular}




\section{Chapter 3. Sediment Transport in Pocomoke Sound, Maryland Inferred from Microfossils in Surface Sediments}

D. A. Willard*, T. M. Cronin*, C. E. Bernhardt*, J. Damon*

*U.S. Geological Survey, Reston, Virginia 20192

\section{Introduction}

The distribution of pollen and benthic foraminifers in surface sediments of estuaries and adjacent tributaries can provide a tool to evaluate shoreline erosion and transport of sediment of various grain sizes from coastal marshes into the main channels of estuaries. Pollen grains produced by plants living in tidal marshes adjacent to estuaries can be transported from the location of their production, and, when compared to windblown pollen from terrestrial plants (i.e., oak, pine pollen), can provide evidence transport of sedimentary particles in the size range of 10-150 microns. Like marsh pollen, species of benthic foraminifers that, due to their ecology exclusively inhabit coastal marshes, can be transported by waves and currents into deeper water and provide evidence for transport of sedimentary particles in the size range of $\sim 150$ to 1000 microns. This chapter evaluates the distribution of pollen and benthic foraminifers in surface sediments in Pocomoke Sound (Figure 3.1) to assess the relative influx of sediments from shoreline regions.

\section{Regional Setting}

The Pocomoke River is a blackwater, low-energy, low-gradient, Coastal Plain river on the Eastern Shore of Maryland, Delaware, and Virginia with a drainage area of $1,997 \mathrm{~km}^{2}$. The river is $\sim 50 \mathrm{~km}$ long, and the upper $25 \mathrm{~km}$ were channelized in the 1920 's to facilitate agricultural activities in that region. As early as 1939, much of the upper reaches of the watershed had been lumbered, drained and cultivated, but the areas near its tidal reaches are thought to be similar to the original forest (Beaven and Oosting, 1939). The Pocomoke watershed lies within the Oak-Pine forest region, which was dominated by oaks with abundant pines and hickories before land clearance (Braun, 
1950). Adjacent to the river are bottomland swamps that ranged form $<1-3 \mathrm{~km}$ wide in the 1920's. These swamps are dominated by Taxodium distichum (cypress) and Nyssa biflora (swamp black gum), with Acer rubrum (red maple) abundant in the understory. Fraxinus pennsylvanica (green ash) is common in the understory, and Liquidambar styraciflora is more abundant near the transition to upland forests (Beaven and Oosting, 1939; Alexander, 2003).

Pocomoke Sound is an oligohaline to lower polyhaline ( $<5$ to $>18 \mathrm{ppt}$ ), tidallyinfluenced embayment situated between the mouth of the Pocomoke River and the southern part of Chesapeake Bay. The main channel in the southern portion of the sound ranges from $\sim 5-28 \mathrm{~m}$ in water depths. The main channel is surrounded on the north, west and east by very broad shallow areas $<4 \mathrm{~m}$ water depth. The Pocomoke Sound coastline consists mainly of tidal marshes, which provide habitats for marsh-dwelling foraminifera (Ellison and Nichols 1976).

\section{Material and Methods}

Two sets of surface samples were collected for analysis of microfossils, consisting of one set of estuarine samples for analysis of pollen and calcareous microfossils and the other a set of floodplain samples for analysis of pollen. Estuarine samples were collected during May 2001 in a series of transects in Pocomoke Sound, Maryland (Figure 3.1). Some of the samples were collected using the R/V Kerhin and a Van Veen sampler, and others were collected using a Ponar grab sampler (Table 3.1). From each sample, the upper $2 \mathrm{~cm}$ were collected for microfossil analysis. Approximately 10 grams (wet weight) were sampled for pollen analysis, and 30-40 grams were processed for benthic foraminifera.

Floodplain samples were also collected at eight sites along the length of the river between 1998 and 2000 as part of a broader research project on modern pollen deposition within forested wetlands (Figure 3.2). At each floodplain site, a series of transects was laid out perpendicular to the river channel; clay pads were placed at approximately $50 \mathrm{~m}$ intervals along each transect. At the ends and midpoints of each transect, we collected "mini-cores" of the upper 1-2 cm of sediment using $50 \mathrm{ml}$ centrifuge tubes. After clay pads had been in place for one year, we also collected sediment that accumulated on them 
for comparison with the adjacent surface sediment. The surrounding vegetation was described to correlate pollen assemblages with source vegetation.

Pollen was isolated from sediments using standard palynological preparation techniques (Traverse, 1988; Willard and others, 2003). After drying the sediment, one tablet of Lycopodium spores was added to each sample. Samples were processed with $\mathrm{HCl}$ and $\mathrm{HF}$ to remove carbonates and silicates respectively, acetolyzed (1 part sulfuric acid: 9 parts acetic anhydride) in a boiling water bath for 10 minutes, neutralized, and treated with $10 \% \mathrm{KOH}$ for 10 minutes in a water bath at $70^{\circ} \mathrm{C}$. After neutralization, residues were sieved with $149 \mu \mathrm{m}$ and $10 \mu \mathrm{m}$ nylon mesh to remove the coarse and clay fractions, respectively. When necessary, samples were swirled in a watch glass to remove mineral matter. After staining with Bismarck Brown, palynomorph residues were mounted on microscope slides in glycerin jelly. At least 300 pollen grains were counted from each sample to determine percent abundance and concentration of palynomorphs.

Microfossil samples were washed using a $63 \mu \mathrm{m}$ sieve; 100-300 foraminifera per sample were identified and counted from the $>150 \mu \mathrm{m}$ fraction to calculate percent abundance. Sediment between 63 and $150 \mu \mathrm{m}$ were also scanned for qualitative analysis of smaller benthic foraminifera. We used the taxonomy of Ellison and Nichol (1976) to identify the foraminiferal species; descriptions of Chesapeake Bay foraminifera can be found in Cronin and others (1999), also available online at http://pubs.usgs.gov/pdf/of/of99-45/. Additional ecological information and references are provided in Ellison (1972), Buzas $(1969,1974)$, Cronin and others (2000) and Karlsen and others (2000). Pollen and foraminiferal data are available online at http://geology.er.usgs.gov/eespteam/atlantic/index.htm. Pollen data also are available from the North American Pollen Database

(http://www.ngdc.noaa.gov/paleo/pollen.html).

\section{Results and Discussion}

\section{Pollen: Pocomoke Sound}

Pollen assemblages were dominated uniformly by Pinus pollen (41-71\%) with Quercus pollen subdominant (9-29\%). Other trees consistently present in low percentages include Carya (1.5-6\%) and Liquidambar (sweet gum) (1-9\%) (Table 3.2). 
Nyssa pollen is present in low percentages (usually <1\%) in most samples. Pollen of TCT (Taxodiaceae/Cupressaceae/Taxaceae) is most abundant in samples near the river mouth. Pollen of marsh taxa, including members of the Poaceae (grasses), Cyperaceae (sedges), Asteraceae (excluding Ambrosia (ragweed)), and Typha (cattail), exceed 10\% abundance in all sites with water depth $\leq 2 \mathrm{~m}$ and typically comprise $<5 \%$ at water depths $>3 \mathrm{~m}$ (Figure 3.3). Ambrosia pollen, a common indicator of land clearance, is present in all samples (0.3-5.3\%) but shows no apparent correlation with water depth or distance from shore.

Pocomoke Sound pollen assemblages correspond well with the regional pollen rain preserved at other sites in the southern half of the bay in containing $>40 \%$ Pinus pollen and $\sim 10-30 \%$ Quercus pollen. In contrast, sites from northern Chesapeake Bay have $<40 \%$ Pinus pollen and $>30 \%$ Quercus pollen (Willard and others, in review). When compared to assemblages from deep-water sites in Pocomoke Sound and elsewhere in the bay, assemblages from shallow-water sites ( $<2 \mathrm{mwd})$ are distinguished by the greater abundance of pollen of herbaceous taxa, particularly the non-Ambrosia Asteraceae and Poaceae. These represent marsh taxa growing on or near the shore, and the greater abundance of their pollen in shallow, nearshore surface sediments in Pocomoke Sound indicates that their pollen is not usually transported far from the shoreline source. A similar pattern was noted using Chenopodiaceae pollen in the Port Tobacco Estuary of the Potomac River (Defries, 1986). We also noted that Ambrosia pollen is less abundant in most Pocomoke Sound surface samples (0-5.3\%) than in the mainstem of Chesapeake Bay (typically 3-14\%). Because Pocomoke Sound is surrounded by marshes and forests, the lower Ambrosia abundance in the Sound probably reflects the relatively small amount of land clearance and agricultural activity in the area surrounding the Sound.

\section{Pollen: Pocomoke River Floodplain Sites}

Floodplain pollen assemblages are dominated by a combination of Liquidambar, Pinus, and Quercus pollen, depending on their location within the watershed. In general, upstream sites have greater percentages of Liquidambar, whereas downstream sites have greater abundance of Pinus and Quercus pollen (Table 3.3). North of Whitons Crossing, 
the river has been channelized extensively to improve drainage for agriculture. At sites in this part of the river (Delaware Crossing, Cypress, Willards, Whitons Crossing), Liquidambar pollen abundance is greatest (25-61\%), and Acer pollen is relatively common (4-7\%); Pinus and Quercus pollen comprise 10-24\% and 6-21\% of assemblages, respectively. At non-channelized sites farther downstream, Pinus and Quercus average $43 \%$ and $14 \%$ of the assemblages, respectively, whereas Liquidambar pollen comprises only $4-11 \%$ of assemblages. At all of these floodplain sites, Nyssa pollen is abundant (up to $33 \%$ ) and Taxodium common (up to 17\%). Herbaceous pollen (Chenopodiaceae, Asteraceae, Poaceae) is relatively rare (1-3\%), and Ambrosia pollen comprises up to $12 \%$ of assemblages.

The floodplain sites differ from the estuarine sites in their lower abundance of Pinus pollen (typically <45\%) and much greater abundance of Liquidambar and Nyssa pollen (usually $>10 \%$ and $>5 \%$, respectively). Pollen of Taxodium and Acer also are common in floodplain deposits, averaging $2-6 \%$ and $1-7 \%$ of assemblages, respectively. The comparatively poor representation of pollen of these taxa in sites distal to the forested wetland indicates that pollen of these plants is preferentially deposited under the forest canopy with minimal fluvial transport from the forested wetland downstream to the sound.

\section{Foraminifera: Pocomoke Sound}

Benthic foraminiferal assemblages from surface sediments from Pocomoke Sound reveal the a salinity-influenced distribution pattern shown graphically in Figure 3.3. In the distal-most regions of the sound, where highest salinities are found nearest the marine source, Elphidium, a genus preferring polyhaline salinity in Chesapeake Bay, is the dominant taxon. As one moves northward into generally lower salinity regions, many samples have greater relative proportions of Ammonia, which prefers mesohaline salinities. Still closer to the Pocomoke River mouth, one finds increased proportions of Ammobaculites, a genus that thrives on organic substrates in salinities usually $<5-10 \mathrm{ppt}$. Some nearshore samples also contain low proportions of Miliammina fusca, a species which inhabits shallow, nearshore habitats off tidal marshes. Finally, in a sample taken 
close to shore in the northern part of the sound (TR-3), one finds marsh-dwelling species of Trochammina, with lesser amount of Miliammina, and Ammoastuta.

Although there are exceptions to this general pattern, these results are consistent with findings in other regions of the Chesapeake Bay region that the primary control of benthic foraminiferal distributions in Chesapeake Bay is the strong salinity gradient in the estuary. Ellison and Nichols (1970) observed nearly identical qualitative patterns in tributary-to-bay transects of foraminiferal samples taken in the Rappahannock River and by Ellison and Nichols (1976) in the James River. With the exception of relatively large proportions of Ammobaculites at PC-6B (station 2, Figure 3.3) and low proportions of marsh species at PC-3B (station 6b; Figure 3.3), the overall pattern indicates surface sediments contain assemblages of benthic foraminifers that lived at or near the sampling stations. Minimal transport of foraminiferal specimens from marshes and adjacent shallow water regions is indicated by these results.

\section{Conclusions}

The results of our analyses of pollen and foraminifera from Pocomoke Sound surface sediments suggest that neither the upstream forested wetlands nor coastal marshes bordering the sound have contributed appreciably to particulate matter in the 10- to 1000micron size range that is currently being deposited in the sound. These results can be interpreted in light of monitoring records of SAV and coastal habitats from the Pocomoke region. In a comprehensive study using aerial and field analysis of SAV beds, water quality monitoring data, and spatial data on coastline from the Maryland Geological Survey (MGS), Orth and others (2002) conducted detailed analyses of SAV trends in Tangier and the northwestern border of Pocomoke Sound for the period 1992-1998. While acknowledging that coastal land loss can have both a negative and positive impact on SAV beds, they concluded that during that period there was no apparent correlation between land loss measured by the MGS spatial data and SAV coverage in the greater Tangier-northern Pocomoke Sound region.

Orth and others (2002 also conducted an analysis of shoreline history in the vicinity of Cedar, Clump and Big Islands along Pocomoke Sound's northern border. They showed that this region had either a stable or an accreting coast between the years 
1942 and 1988. This situation is in sharp contrast with most regions of Tangier Sound, which experienced low to severe coastal land loss. Thus, the available evidence from historical maps of coastal regions in the northern part of our study region suggests that it is unlikely that major erosion of marshes occurred during the past few decades. Although long -term shoreline data were not analyzed for the Virginia portion of Pocomoke Sound, if the trends in Maryland apply to other parts of Pocomoke Sound, it would be consistent with our findings of minimal transport of marsh pollen and foraminifers to central parts of the sound.

\section{Acknowledgements}

We thank Rick Younger, Jeff Halka, and the crew of the R/V Kerhin for assistance in obtaining surface samples in Pocomoke Sound. Cliff Hupp, Mike Shenning, Patrick Buchanan, and Lisa Weimer helped collect surface samples from the Pocomoke River

floodplain. We thank Tom Sheehan and Chris Nytch for laboratory assistance.

\section{References}

Alexander, L.A., 2003, A multi-scale view of plant diversity and hydrogeomorphology in Chesapeake Bay forested wetlands. Ph.D. Dissertation, Harvard University: Cambridge, MA, 283 pp.

Beaven, G.F., Oosting, H.J., 1939, Pocomoke Swamp: a study of a cypress swamp on the eastern shore of Maryland. Bulletin of the Torrey Botanical Club 66: 367-389. Braun, E.L., 1950, Deciduous forests of eastern North America. The Blakiston Company, Philadelphia.

Buzas, M. A. 1969, Foraminiferal species densities and environmental variables in an estuary. Limnology and Oceanography 14: 411-422.

Buzas, M. A. 1974, Vertical distribution of Ammobaculites in the Rhode River, Maryland. Journal of Foraminiferal Research 4: 144-147.

Cronin, T. M., Wagner, R. S., and Slattery, M. (eds.)., 1999, Microfossils from Chesapeake Bay sediments: Illustrations and species database. USGS Open-file Report 99-45. (includes 5 chapters, one on each major microfossil group. Also available on WWW: http://pubs.usgs.gov/pdf/of/of99-45/). 
Cronin, T. M., Willard, D. A., R. T. Kerhin, A. W. Karlsen, C. Holmes, S. Ishman, S. Verardo, J. McGeehin, A. Zimmerman., 2000, Climatic variability over the last millennium from the Chesapeake Bay sedimentary record. Geology 28: 3-6.

Defries, R.S., 1986. Effects of land-use history on sedimentation in the Potomac estuary, Maryland. U.S. Geological Survey Water-Supply Paper 2234-K: 1K1-K23.

Ellison, R. L., 1972, Ammobaculites, a foraminiferal proprieter of Chesapeake Bay estuaries. Geological Society of America Bulletin 133: 247-262.

Ellison, R. L. and Nichols, M. M., 1970, Ecology of foraminifera from the Rappahannock Estuary, Virginia. Cushman Foundation for Foraminiferal Research Contributions 21: $1-17$.

Ellison, R. L. and Nichols, M. M., 1976, Modern and Holocene foraminifera in the Chesapeake Bay region, p. 131-151. In, International Symposium on Benthonic Foraminifera of Continental Margins, Part A. Maritime Sediments Special Publication 1.

Karlsen, A.W., Cronin, T. M. Ishman, S. E., Willard, D. A., Holmes, C. A. Marot, M., and Kerhin, R., 2000, Historical trends in Chesapeake Bay dissolved oxygen based on benthic foraminifera from sediment cores. Estuaries: 23 (4): 488-508.

Orth, R., Moore, K., Fishman, J. Wilcox, D. L. Karrh, and T. Parham., 2002., Causes of submerged aquatic vegetation decline in Tangier Sound, Chesapeake Bay.

Traverse, A., 1988., Paleopalynology. Boston: Unwin Hyman Publishers, 600 pp.

Willard, D.A., Cronin, T.M., and Verardo, S., 2003, Late-Holocene climate and ecosystem history from Chesapeake Bay sediment cores, USA. The Holocene 13: 201-214.

Willard, D.A., Bernhardt, C.E., Korejwo, D.A., and Meyers, S.R., in review, Eastern North American Terrestrial Ecosystem Response to Millennial-Scale Holocene Climate Variability: Pollen-Based Climatic Reconstruction. Global and Planetary Change. 


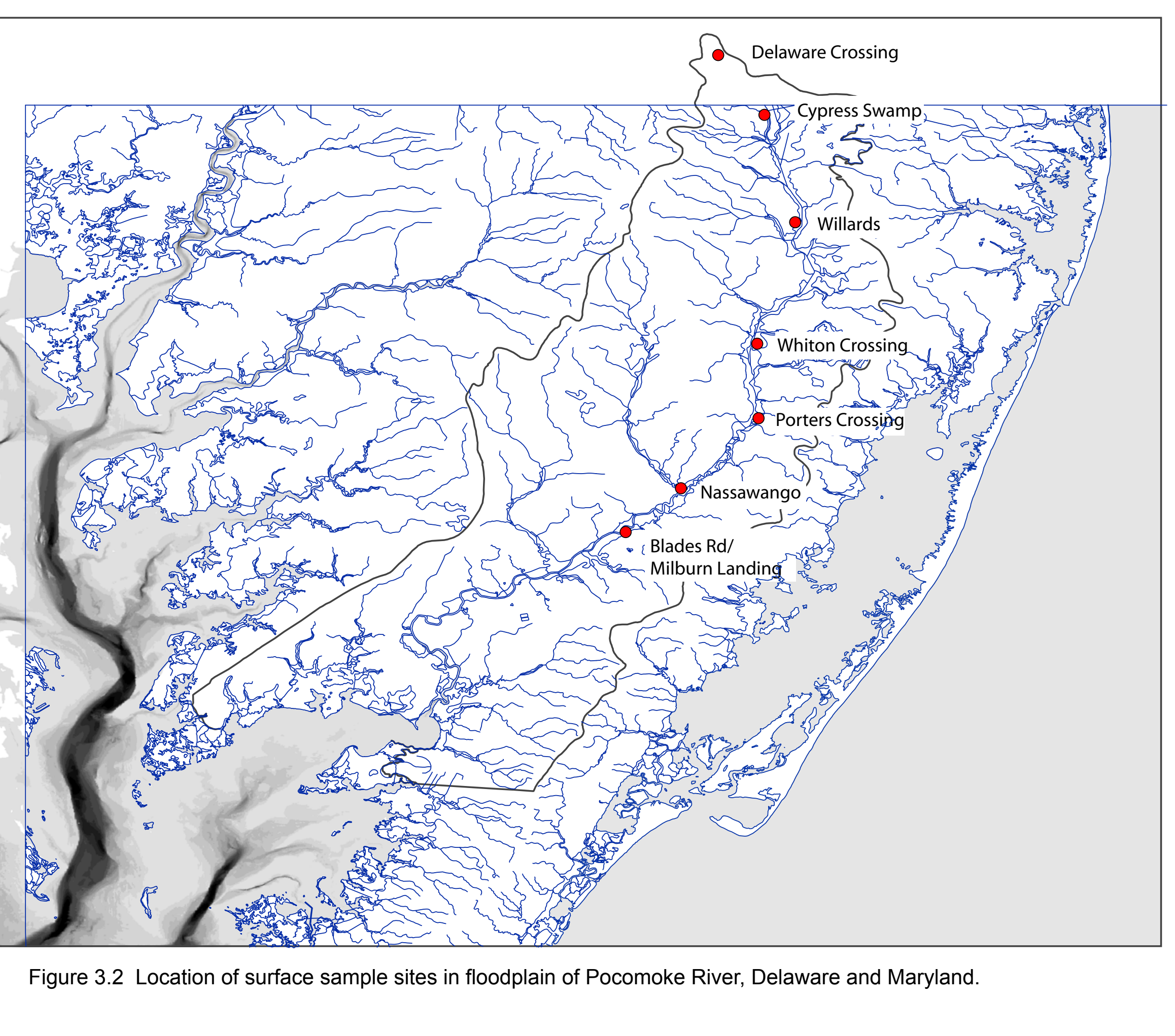




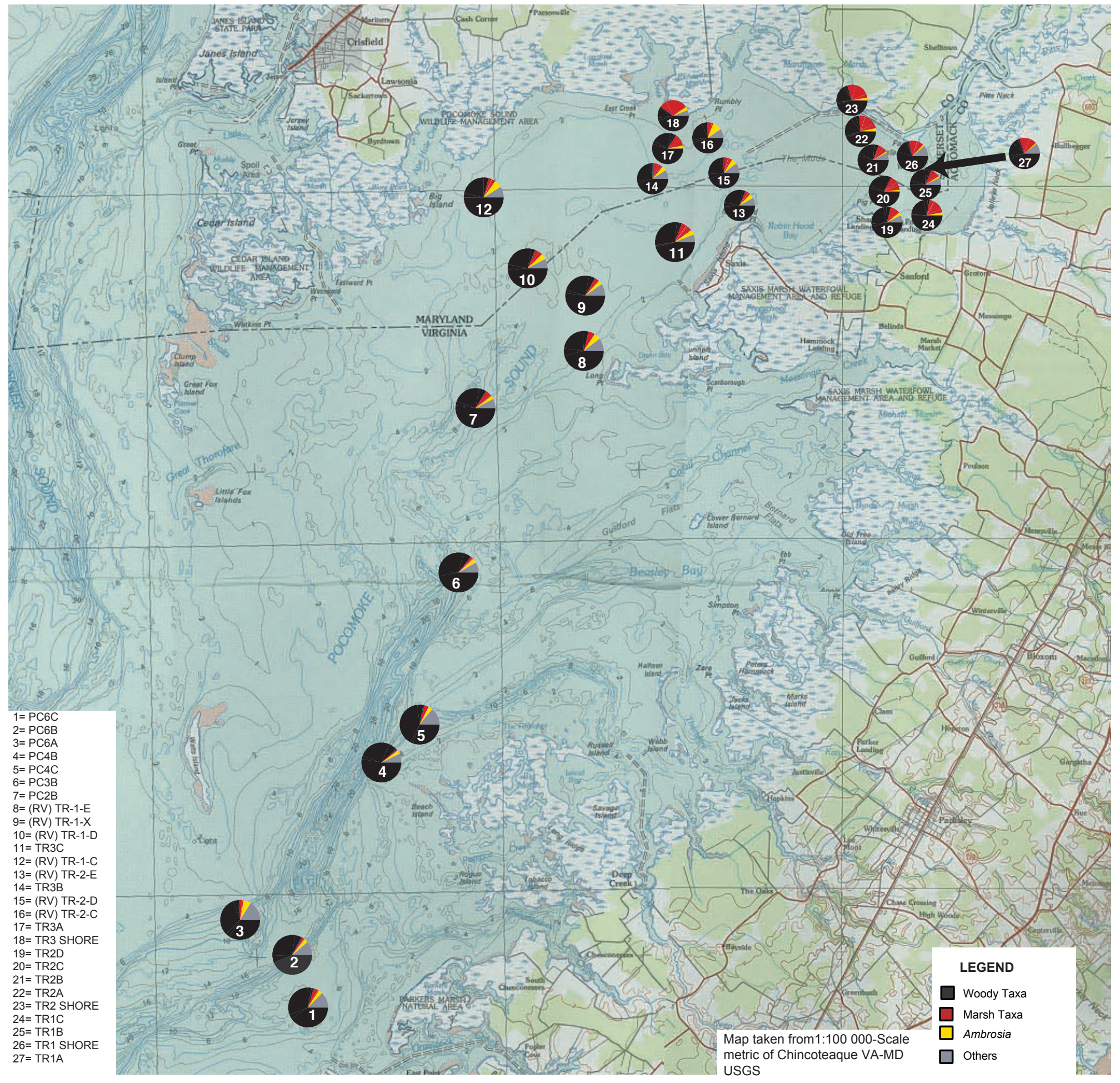

Figure 3.3. Percent abundance of pollen in surface sediments, Pocomoke Sound, Maryland. 


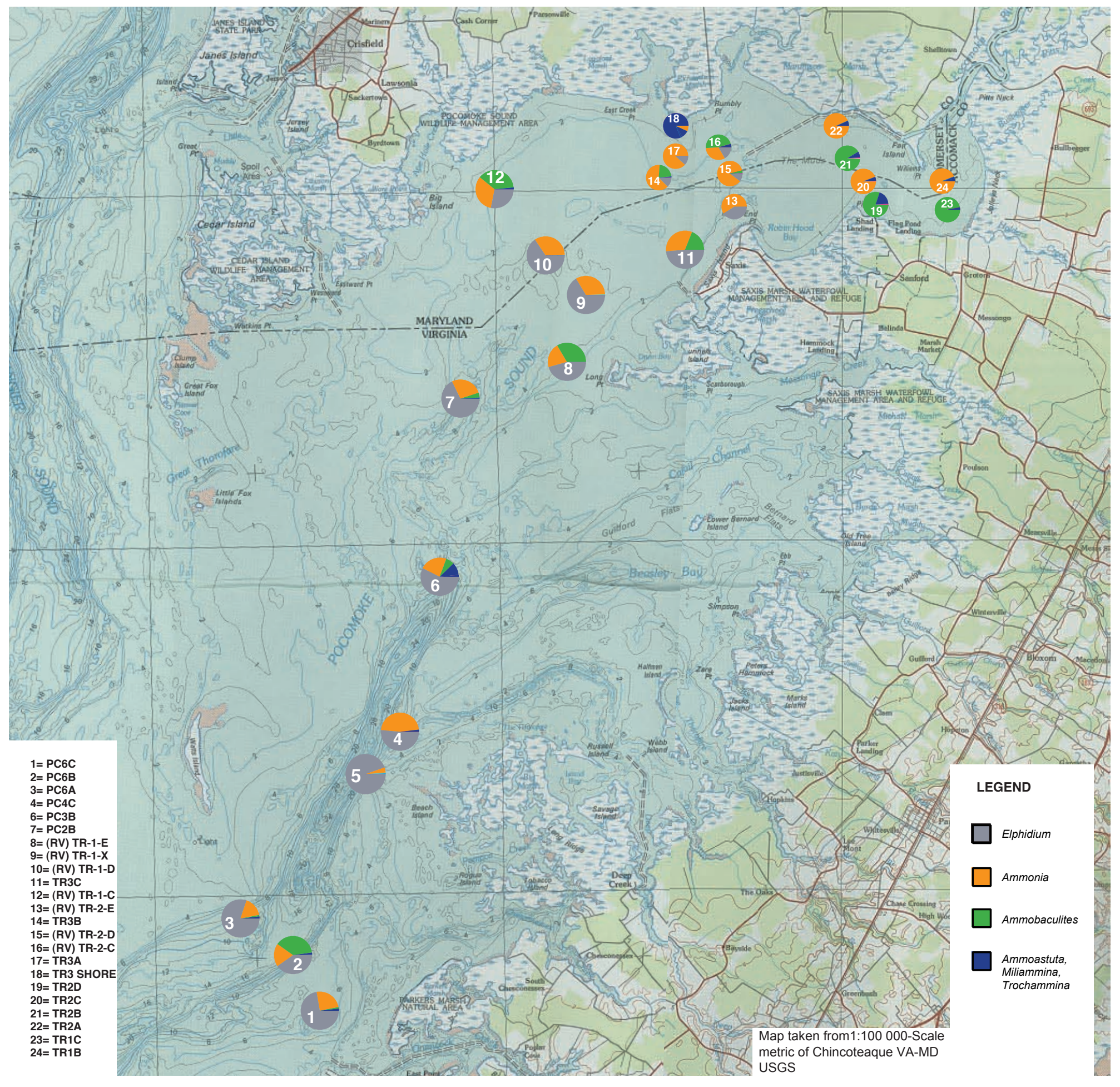

Figure 3.4 Percent abundance of foraminiferal genera in surface sediments, Pocomoke Sound, Maryland. 
Table 3.1 - Locations of surface sites for pollen and foraminiferal analyses, Pocomoke Sound.

\begin{tabular}{|c|c|c|c|c|}
\hline Site\# & Date & Latitude (N) & Longitude (W) & Water Depth (m) \\
\hline (RV)TR-1-C & $16 / 5 / 01$ & $37^{\circ} 56.821^{\prime}$ & $75^{\circ} 47.664^{\prime}$ & 3 \\
\hline (RV)TR-1-D & $15 / 5 / 01$ & $37^{\circ} 55.766^{\prime}$ & $75^{\circ} 46.868^{\prime}$ & 3.8 \\
\hline (RV)TR-1-E & $15 / 5 / 01$ & $37^{\circ} 54.445^{\prime}$ & $75^{\circ} 45.944^{\prime}$ & 3.6 \\
\hline (RV)TR-1-X & $15 / 5 / 01$ & $37^{\circ} 55^{\prime}$ & $75^{\circ} 46^{\prime}$ & 3.7 \\
\hline (RV)TR-2-C & $16 / 5 / 01$ & $37^{\circ} 57.402^{\prime}$ & $75^{\circ} 43.585^{\prime}$ & 2.6 \\
\hline (RV)TR-2-D & $16 / 5 / 01$ & $37^{\circ} 57.037^{\prime}$ & $75^{\circ} 43.516^{\prime}$ & 3.4 \\
\hline (RV)TR-2-E & $16 / 5 / 01$ & $37^{\circ} 56.758^{\prime}$ & $75^{\circ} 43.442^{\prime}$ & 3.4 \\
\hline PC2B & $15 / 5 / 01$ & $37^{\circ} 53.429^{\prime}$ & $75^{\circ} 48.408^{\prime}$ & 7.9 \\
\hline PC3B & $15 / 5 / 01$ & $37^{\circ} 50.741^{\prime}$ & $75^{\circ} 48.745^{\prime}$ & 11.4 \\
\hline PC4B & $15 / 5 / 01$ & $37^{\circ} 48.300^{\prime}$ & $75^{\circ} 50.301^{\prime}$ & 27.3 \\
\hline PC4C & $15 / 5 / 01$ & $37^{\circ} 48.496^{\prime}$ & $75^{\circ} 49.820^{\prime}$ & 7.3 \\
\hline PC6A & $15 / 5 / 01$ & $37^{\circ} 45.631^{\prime}$ & $75^{\circ} 52.815^{\prime}$ & 8 \\
\hline PC6B & $15 / 5 / 01$ & $37^{\circ} 44.910^{\prime}$ & $75^{\circ} 52.334^{\prime}$ & 14.6 \\
\hline PC6C & $15 / 5 / 01$ & $37^{\circ} 44.266^{\prime}$ & $75^{\circ} 51.927^{\prime}$ & 7.3 \\
\hline Poke Rvr T-3 & $14 / 5 / 01$ & $38^{\circ} 04.126^{\prime}$ & $75^{\circ} 34.878^{\prime}$ & 3 \\
\hline $\mathrm{T}-1$ & $14 / 5 / 01$ & $37^{\circ} 58.842^{\prime}$ & $75^{\circ} 37.831^{\prime}$ & 1.4 \\
\hline TR-1A & $15 / 5 / 01$ & $37^{\circ} 57.157^{\prime}$ & $75^{\circ} 39.422^{\prime}$ & 1.25 \\
\hline TR-1-B & $15 / 5 / 01$ & $37^{\circ} 57.019^{\prime}$ & $75^{\circ} 39.353^{\prime}$ & 2.1 \\
\hline TR-1-C & $15 / 5 / 01$ & $37^{\circ} 56.602^{\prime}$ & $75^{\circ} 39.242^{\prime}$ & 1.8 \\
\hline TR-1-Shore & $15 / 5 / 01$ & $37^{\circ} 57.208^{\prime}$ & $75^{\circ} 39.405^{\prime}$ & 0 (on shore) \\
\hline TR-2-A & $15 / 5 / 01$ & $37^{\circ} 57.811^{\prime}$ & $75^{\circ} 40.605^{\prime}$ & 1.4 \\
\hline TR-2-B & $15 / 5 / 01$ & $37^{\circ} 57.249^{\prime}$ & $75^{\circ} 40.456^{\prime}$ & 2 \\
\hline TR-2-C & $15 / 5 / 01$ & $37^{\circ} 56.717^{\prime}$ & $75^{\circ} 40.316^{\prime}$ & 1.8 \\
\hline TR-2-D & $15 / 5 / 01$ & $37^{\circ} 56.473^{\prime}$ & $75^{\circ} 40.257^{\prime}$ & 1.6 \\
\hline TR-2-Shore & $15 / 5 / 01$ & $37^{\circ} 58.048^{\prime}$ & $75^{\circ} 40.665^{\prime}$ & 0 (on shore) \\
\hline TR-3-A & $15 / 5 / 01$ & $37^{\circ} 57.513^{\prime}$ & $75^{\circ} 44.151^{\prime}$ & 1.5 \\
\hline TR-3-B & $15 / 5 / 01$ & $37^{\circ} 57.085^{\prime}$ & $75^{\circ} 44.098^{\prime}$ & 1.9 \\
\hline TR-3-C & $16 / 5 / 01$ & $37^{\circ} 55.846^{\prime}$ & $75^{\circ} 44.084^{\prime}$ & 1.9 \\
\hline TR-3-Shore & $15 / 5 / 01$ & $37^{\circ} 57.787^{\prime}$ & $75^{\circ} 44.212^{\prime}$ & 0 (on shore) \\
\hline
\end{tabular}

\#RV means taken on RV Kerhin with Van Veen grab sampler except those in $<3 \mathrm{~m}$, taken by hand sampler 
Table 3.2. Percent abundance o pollen in surface samples, Pocomoke Sound.

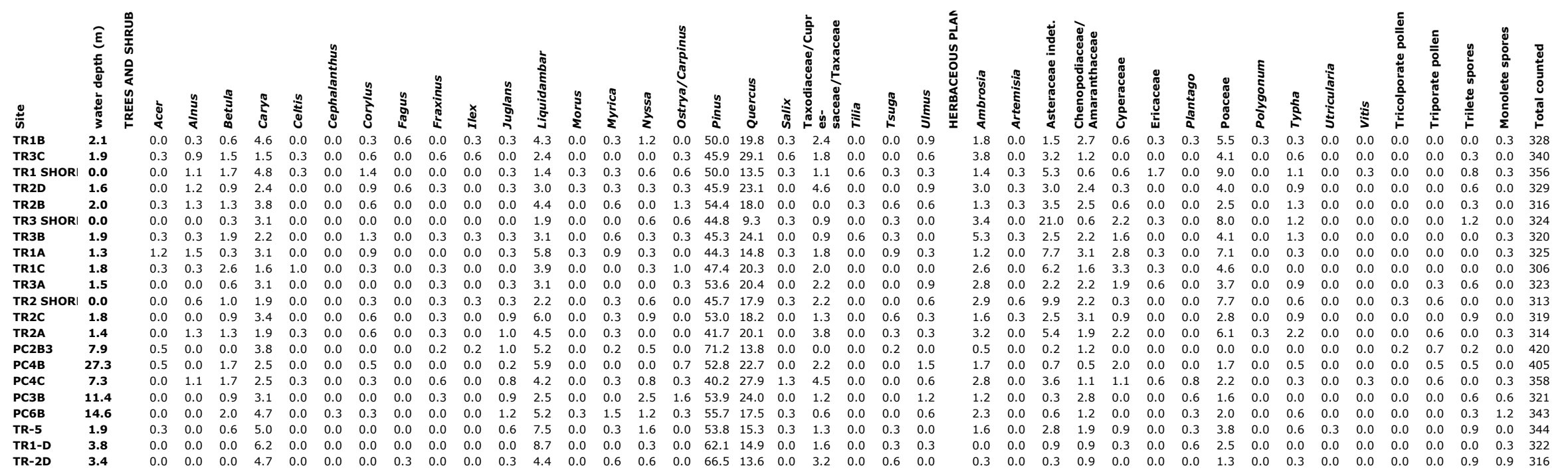


Table 3.3. Abundance of foraminifera in Pocomoke Sound Surface Samples.

\begin{tabular}{|c|c|c|c|c|c|c|c|c|}
\hline$\frac{\vec{a}}{\frac{2}{3}}$ & 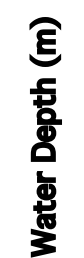 & $\frac{5}{\frac{5}{5}}$ & $\begin{array}{l}\frac{\pi}{5} \\
\frac{8}{8}\end{array}$ & 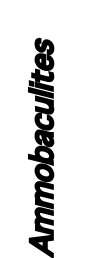 & 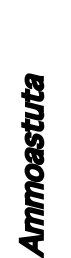 & 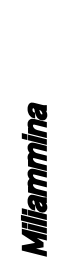 & $\begin{array}{l}\frac{\pi}{8} \\
\frac{5}{8} \\
\frac{8}{8}\end{array}$ & 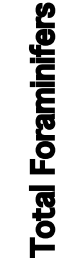 \\
\hline (RV)TR-1-C(VV) & 3 & 89 & 103 & 119 & & 5 & & 316 \\
\hline (RV)TR-1-D(VV) & 3.8 & 208 & 107 & 2 & & & & 317 \\
\hline (RV)TR-1-E(VV) & 3.6 & 139 & 63 & 102 & & & & 304 \\
\hline (RV)TR-1-X(VV) & 3.7 & 201 & 100 & 2 & & & & 303 \\
\hline (RV)TR-2-C(VV) & 2.6 & 51 & 98 & 142 & 1 & 13 & & 305 \\
\hline (RV)TR-2-D(VV) & 3.4 & 31 & 261 & 10 & & & 2 & 304 \\
\hline (RV)TR-2-E(VV) & 3.4 & 128 & 185 & & & & & 313 \\
\hline $\mathrm{PC} 2 \mathrm{~B}$ & 7.9 & 206 & 83 & 12 & & 3 & & 304 \\
\hline PC3B(VV) & 11.4 & 178 & 72 & 22 & & 33 & 5 & 310 \\
\hline PC4B(VV) & 27.3 & 284 & 12 & 2 & & 2 & & 300 \\
\hline PC4C(VV) & 7.3 & 52 & 47 & & & 2 & & 101 \\
\hline PC6A(VV) & 8 & 81 & 17 & & & 1 & 2 & 101 \\
\hline PC6B & 14.6 & 123 & 60 & 116 & & 6 & 1 & 306 \\
\hline PC6C(VV) & 7.3 & 73 & 25 & & & 1 & 2 & 101 \\
\hline TR-1-B & 2.1 & & 95 & & 1 & 2 & 3 & 101 \\
\hline TR-1-C & 1.8 & & & 98 & & 3 & & 101 \\
\hline TR-2-A & 1.4 & & 96 & & & 7 & & 103 \\
\hline TR-2-B & 2 & & 1 & 95 & 2 & 6 & 1 & 105 \\
\hline TR-2-C & 1.8 & & 96 & & & 5 & 1 & 102 \\
\hline TR-2-D & 1.6 & & & 80 & & 19 & 1 & 100 \\
\hline TR-3-A & 1.5 & 6 & 45 & & & & & 51 \\
\hline TR-3-B & 1.9 & 38 & 193 & 67 & & 4 & 1 & 303 \\
\hline TR-3-C & 1.9 & 149 & 99 & 58 & & & & 306 \\
\hline TR-3-shore & 0 & & 7 & & 10 & 2 & 82 & 101 \\
\hline
\end{tabular}




\section{Chapter 4. Stratigraphy and Age of Pocomoke Sound Sediments}

T. M. Cronin*, M. Robertson*, D. Willard*, J. Halka**

*U.S. Geological Survey, Reston, Virginia 20192

**Maryland Geological Survey, Baltimore, Maryland 21218

\section{Introduction}

The stratigraphy and sedimentary history of many regions of the mainstem channel of Chesapeake Bay (Goldberg and others, 1977; Officer and others, 1984; Cooper and Brush, 1991; Cronin and others, 2000; 2003) and marshes around the margins of the bay (Brush, 1984; Kearney, 1996; Brush and Hilgartner, 2000) has been well studied using various types of sediment cores. In contrast, the sedimentary record and depositional and environmental history of Pocomoke Sound is almost completely unstudied. This chapter describes the general stratigraphic framework of Chesapeake Bay based on prior studies and the stratigraphy and age of sediments cored in 2001 in Pocomoke Sound.

\section{Previous Studies of Chesapeake Bay Quaternary Geology}

The Neogene and Quaternary history of Chesapeake Bay recently has been discussed by Hobbs (2004) in a review of the literature of both onshore and submarine geological units. Our study concerns only the Holocene sediments from the Pocomoke Sound region, which like other parts of Chesapeake Bay and the Delmarva Peninsula, is the product of late Quaternary sea-level oscillations caused by glacial-interglacial climatic cycles (Shideler and others, 1984; Colman and Hobbs, 1987); Colman and Mixon, 1988). Colman and others (1988) used geophysical and borehole data to reconstruct the development of a series of paleochannels and channel infilling in Chesapeake Bay and the Delmarva Peninsula. They recognized three generations of paleo-channel development, which are referred to as the Exmore, Eastville and Cape Charles paleochannels. These channels formed during glacial periods when global sea level was about 100-120 m below its present level. Estuarine sediment infilled each channel during the subsequent period of interglacial high sea level, and each sequence of 
paleo-channel fill is separated from the underlying sediments by an erosional unconformity. Recent long sediment coring studies indicate that in some regions, fluvial and marsh sediments underlie estuarine sediments at the base of each channel fill sequence (Cronin, 2000).

The youngest channel to develop, the Cape Charles paleochannel, formed during the low sea level of the last glacial maximum, around $20 \mathrm{ka} \mathrm{BP.} \mathrm{In} \mathrm{the} \mathrm{Pocomoke} \mathrm{Sound}$ region, geophysical studies suggest that approximately 10 to $25 \mathrm{~m}$ of Holocene sediment was deposited above the Cape Charles Erosional Surface (CCES) (Colman and Hobbs, 1987). Based on the well-dated sedimentary record from the mainstem channel of Chesapeake Bay (Cronin, 2000; Colman and others, 2002; Bratton and Colman, 2003), it is presumed that most of the Pocomoke Sound sediments lying above the CCES represent Holocene estuarine sediments deposited during the past 8 ka years, although the lowermost sediments may represent pre- 8 ka year fluvial sediments deposited before the final phase of global sea level rise flooded the bay. The current study focuses on the uppermost five meters of late Holocene sequence lying above the unconformity of the CCES.

\section{Pocomoke Sound Core Site Descriptions}

Core sites in Pocomoke Sound were selected on the basis of geophysical records of Colman and Hobbs (1987) (Figure 4.1). The coring strategy for May 2001 was designed to take transects of short cores (1-2 m core length) across different parts of the deep Pocomoke Sound channel in order to obtain basic information on sediment characteristics of Pocomoke Sound sediment in shallow and deeper water regions. In transects where three cores could be obtained (i.e., cores PC-2A-C; PC-3A-C, PC-6A-C) the " $\mathrm{B}$ " sites in each transect represented locations in the deeper main channel of the sound, the "A" and "C" sites were situated on the adjacent shallow water flanks. The initial results from these cores demonstrated that the deeper channel was the site of finegrained sediment deposition, and the flanks of the channel consisted mostly of coarsegrained sands. This pattern is similar to that found elsewhere in the mainstem of Chesapeake Bay. On the basis of their physical characteristics, lithology, X-radiographs, micropaleontology, and chronology, two sites, PC-2B and PC-6B, were selected as 
having the greatest potential to obtain a high-resolution paleoecological and sedimentary record and long cores $(\sim 5 \mathrm{~m}$ long) were taken at these sites in September 2001.

\section{Lithological Descriptions of Cores}

Lithological descriptions and X-radiographs for seven cores (PC-2B, PC-3A, PC3B, PC-4B, PC-4C, PC-6A and PC-6B) from the central sound and lithological descriptions for three cores in the northern part of the sound (TR-1D, TR-2D, TR-5D) are provided at this url: http://geology.er.usgs.gov/eespteam/atlantic/index.htm.

Sediments in cores taken in the Pocomoke Sound channel are similar to those found in the main channel of Chesapeake Bay, consisting predominantly of methane-rich muds, with occasional shells and light-dark laminae (Figures 4.2, 4.3). These lithologies are ideal for detailed paleoecological and chronological study due to the relatively continuous fine-grained sedimentation and common fossilized remains of ecological indicators. In contrast to the fine-grained sediments in the channel, sediments blanketing the flanks of Pocomoke Sound consist mainly of sands typical of shallow regions throughout most of the Chesapeake Bay (Figure 4.4). These probably represent lag deposits in which the fine-grained size fractions have been transported into the deeper channel. Such sandy deposits are difficult to recover using gravity and piston coring methods. Moreover, they usually do not contain material suitable for either radiocarbon dating, (i.e., mollusk shells are broken and transported), or lead-210 dating (little finegrained material). For these reasons, the shallow sandy facies of Pocomoke Sound were not used for paleoecological analysis.

Sediments in cores PC-4B and PC-4C exhibit notable differences from those found in other channel cores. Core PC-4C, recovered in $7.3 \mathrm{~m}$ water depth, is predominantly light gray mud, interspersed with concentrations of black organics, from the bottom of the core at $100 \mathrm{~cm}$ up to $25 \mathrm{~cm}$ (Figure 4.5). From $25 \mathrm{~cm}$ to $10 \mathrm{~cm}$, a sandy, pebbly facies was deposited, and a large mollusk was present at $16 \mathrm{~cm}$. Highly bioturbated silty-sandy muds were deposited in the upper $10 \mathrm{~cm}$ of the core. Core PC-4B was collected in $27.3 \mathrm{~m}$ of water but exhibits fairly unusual sediments for a low energy channel-type environment. From the bottom of the core at $118 \mathrm{~cm}$ up to a possibly planar unconformity at $75 \mathrm{~cm}$, the core exhibits alternating packages of pebble beds overlain by 
light gray non-planar-wavy mud and sand laminations overlain by thick brown organics. These packages become increasingly more non-planar with depth. From $75 \mathrm{~cm}$ to $25 \mathrm{~cm}$, poorly sorted mud and sand are interlaminated with $\mathrm{mm}$ to $\mathrm{cm}$-scale gravel beds. In the upper $25 \mathrm{~cm}$, organic mats are scattered throughout the dominant mud lithology. A bryozoan mat caps the upper $2 \mathrm{~cm}$. Due to the complexity of the sedimentary history at these sites only the pollen was studied in any detail from these sites.

A final group of cores were taken in the northern region of Pocomoke Sound (Cores TR-1, TR-2, and TR-5), where sediments typically consist of coarse-grained sediment with abundant plant matter, especially in the upper tens of centimeters.

\section{Radiocarbon Dates and Pollen Biostratigraphy}

\section{Core PC-6B-2}

Seven radiocarbon dates were obtained from this $476 \mathrm{~cm}$ long piston core using an accelerator mass spectrometer (AMS); six dates were obtained on shells, and one was from a bryozoan (Table 4.1). Ages given below are calendar years (cal yrBP) obtained by converting radiocarbon ages into calendar years using the calibration program CALIB 4.4 (Stuiver and others, 1998). Four dates collected in the upper $205 \mathrm{~cm}$ were too young to calibrate and they probably represent sediments deposited during the last century. The other three dates from samples collected between $430 \mathrm{~cm}$ and $458 \mathrm{~cm}$ each indicate ages between 460-480 cal yrBP.

The radiocarbon dates are consistent with pollen biostratigraphic data showing the initial Colonial land clearance during the $17^{\text {th }}$ century marked by the first increase in Ambrosia pollen $>1 \%$ at $340 \mathrm{~cm}$. This marker horizon is stratigraphically above the oldest radiocarbon dates ( 460-480 yr BP, see Willard and others, this volume). The peak in Ambrosia pollen, which has been correlated to large-scale land clearance between $\sim 1880$ and $1910 \mathrm{AD}$, occurs at $280 \mathrm{~cm}$ in core PC-6B. This marker horizon lies stratigraphically below the young radiocarbon dates from material in the upper two meters. The estimated age based on pollen is also within the age uncertainty from the ${ }^{210} \mathrm{~Pb}$-based model for this same core $(\sim 1900 \mathrm{AD}$ at $225 \mathrm{~cm}$, see Holmes and Marot, this volume). 


\section{Core TR-2-D}

One radiocarbon date was obtained on bivalves and oysters from 66-68 cm depth in this core, yielding an age of $520 \mathrm{cal}$ yrBP. The extremely high abundance of Pinus pollen throughout the $72 \mathrm{~cm}$ length of this core indicates that the entire thickness was deposited within the last century. The apparent contradiction of pollen biostratigraphy and radiocarbon dating merits further examination.

\section{Core TR-1-D}

One radiocarbon date was obtained on an oyster fragment from 30-34 cm depth in core TR-1-D, which yielded an age too young too calibrate. This is consistent with pollen evidence, which indicates that entire 92-cm long core was deposited within the last century.

\section{Site $P C-2 B$}

Several cores were obtained at this site, and radiocarbon dates were obtained from two cores (Table 4.1). In core PC-2B-1, bivalve fragments and gastropods from 196-198 cm yielded conventional radiocarbon dates of 108.4 pMC (percent modern carbon), indicating that they were deposited after $\sim 1950$. Likewise, in core PC-2B-3, Mulinia shells from $219 \mathrm{~cm}$ depth yielded a conventional radiocarbon age of $107.2 \mathrm{pMC}$, also suggesting a post-1950 AD age. Three other radiocarbon dates were obtained from the 450-cm long PC-2B-3 core, and they indicate that the entire core was deposited after the period of maximum land clearance in the mid to late 1800's (Table 4.1). These radiocarbon ages are consistent with pollen evidence showing abundant Ambrosia pollen $(8 \%)$ at the base of the core (Willard and others, this volume, Chapter 7).

\section{Site $P C-3 B$}

Two cores were obtained and dated from this site: PC-3A and PC-3B. Bivalve and gastropod shells from 40-42 cm depth in core PC-3A yielded ages too young to be calibrated. Bivalve fragments from $168-171 \mathrm{~cm}$ depth in core PC-3B yielded a conventional radiocarbon date of 126.9 pMC, which signifies a post-1950 age. Pollen 
evidence from PC-3B also supports the radiocarbon ages indicating that the entire $170 \mathrm{~cm}$ of sediment at these core sites was deposited during the past century

\section{Core PC- $4 B$}

One radiocarbon date was obtained from bivalve and gastropod fragments collected at 30-32 cm depth in core PC-4B and was too young to be calibrated. This is consistent with pollen evidence indicating that horizon representing large-scale land clearance in the late $19^{\text {th }}$ century is between $40 \mathrm{~cm}$ and $50 \mathrm{~cm}$ depth in the core.

\section{Conclusions}

Radiocarbon, lead-210, and pollen dating of sediment cores from Pocomoke Sound indicate relatively continuous deposition of fine-grained sediments in the main Pocomoke channel. The uppermost sequence of fine-grained sediments taken in cores from $>7 \mathrm{~m}$ water depth was deposited during the past few centuries, suggesting a relatively high mean sedimentation rate $\left(>1 \mathrm{~cm} \mathrm{yr}^{-1}\right)$. Cores from the sandier sediments blanketing the shallow ( $<\sim 7 \mathrm{~m}$ water depth) flanks of Pocomoke Sound were dated only in a preliminary fashion and suggest less continuous and coarser grained sedimentation than was found in the channel. Further discussion of the age models for the cores is provided in Chapters 5-7 in discussions about the paleoecological history of Pocomoke Sound.

\section{Acknowledgements}

Radiocarbon dating of samples were carried out by Beta Analytic Inc; lead-210 dating by C. Holmes and M. Marot, USGS. We thank Capt. Rick Younger and the crew of the R/V Kerhin for assistance in obtaining cores used in this study. X-radiographs were provided by Bill Panagoetou of the Maryland Geological Survey.

\section{References}

Bratton, J. F. and Colman, S. M., 2003, Birth of the modern Chesapeake Bay estuary between 7.4 and $8.2 \mathrm{ka}$ and implications for global sea level rise: Geomarine Letters, v. 22 , p. $188-197$. 
Brush, G. S., 1984, Patterns of recent sediment accumulation in Chesapeake Bay (Virginia-Maryland, U.S.A.) tributaries: Chemical Geology, v. 44, p. 227-242.

Brush, G.S., and Hilgartner, W. B., 2000. Paleoecology of submerged macrophytes in the upper Chesapeake Bay: Ecological Monographs, v. 70 (4), p. 645-667.

Colman, S. M., and Hobbs, C. H., III, 1987, Quaternary geology of the southern Virginia part of the Chesapeake Bay. USGS Miscellaneous Field Investigations, Map MF1948-A.

Colman, S. M., and Mixon, R. M., 1988, The record of major Quaternary sea-level changes in a large coastal plain estuary, Chesapeake Bay, eastern United States: Palaeogeography, Palaeoclimatology, Palaeoecology, v. 69, p. 99-116.

Colman, S. M., Berquist, C. R., and Hobbs, C. H., III, 1988, Structure, age and origin of the bay-mouth shoal deposits, Chesapeake Bay, Virginia: Marine Geology, v. 83, p. 95-113.

Colman, S.M., Baucom, P.C., Bratton, J., Cronin, T.M., McGeehin, J.P., Willard, D.,A., Zimmerman, A., and Vogt, P.R., 2002, Radiocarbon dating of Holocene sediments in Chesapeake Bay: Quaternary Research, v. 57, p. 58-70.

Cooper, S. R., and Brush, G. S., 1991, Long-term history of Chesapeake Bay anoxia: Science, v. 254, p. 992-996.

Cronin, T. M. (ed.), 2000, Initial Report on IMAGES V Cruise of Marion-Dufresne to Chesapeake Bay June, 1999. USGS Open-file Report 00-306, 133 pp.

Cronin, T. M., Willard, D. A., Kerhin, R. T., Karlsen, A., Holmes, C. Ishman, S., Verardo, S., McGeehin, J., Zimmerman, A., 2000, Climatic variability over the last millennium from the Chesapeake Bay sedimentary record: Geology, v. 28, p. 3-6.

Cronin, T. M., Dwyer, G. S., Kamiya, T. Schwede, S., Willard, D. A., 2003, Medieval Warm Period, Little Ice Age and $20^{\text {th }}$ Century Temperature Variability from Chesapeake Bay: Global and Planetary Change, v. 36, (1-2), p. 17-29.

Goldberg. E. D., Hodge, V., Koide, M., Griffin, J., Gamble, E., Bricker, O. P., Matisoff, G., Holdren, G. R., Jr., and Braun, R., 1977, A pollution history of Chesapeake Bay: Geochimica et Cosmochimica Acta, v. 42, p. 1413-1425. 
Hobbs, C. H., III, 2004, Geological history of Chesapeake Bay: Quaternary Science Reviews, v. 23 (5-6), p. 641-661.

Holmes, C. and Marot, M., Sediment and chemical flux history in the Pocomoke Sound as defined by short-lived isotopic analysis: U.S. Geological Survey Open-file Report (this volume).

Kearney, M. S., 1996, Sea-level change during the last thousand years in Chesapeake Bay: Journal of Coastal Research, v. 12 (4), p. 977-983.

Officer, C. B., Lynch, D. R., Setlock, G. H., and Helz, G. R., 1984, Recent sedimentation in Chesapeake Bay, In, “The Estuary as a Filter”, V. S. Kennedy, (ed.), pp. 131-157. Academic Press, New York.

Shideler, G. L., Ludwick, J. C., Oertel, G. F., and Finkelstein, K., 1984, Quaternary stratigraphic evolution of the southern Delmarva Peninsula coastal zone, Cape Charles, Virginia: Geological Society of America Bulletin, v. 95, p. 489-502.

Stuiver, M., Reimer, P.J., and Braziunas, T. F., 1998b, High-precision radiocarbon age calibration for terrestrial and marine samples: Radiocarbon, v. 40, p. 1127-1151.

Willard, D. A., Cronin, T. M., Bernhardt, C. E. and Damon, J., Sediment Transport in Pocomoke Sound, Maryland Inferred from Microfossils in Surface Sediments U.S. Geological Survey Open-file Report, this volume. 


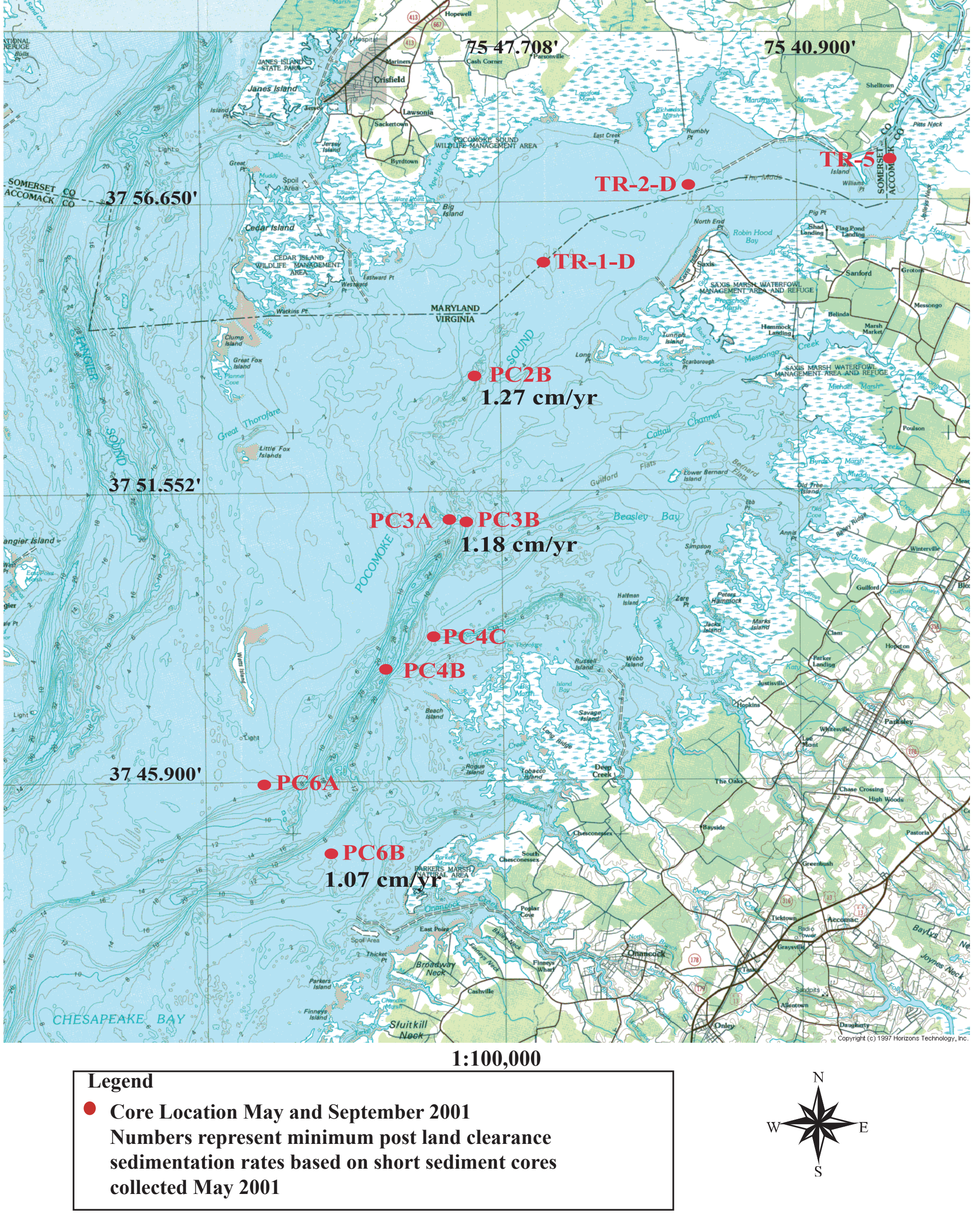

Figure 4.1. Location of cores collected within Pocomoke Sound. 


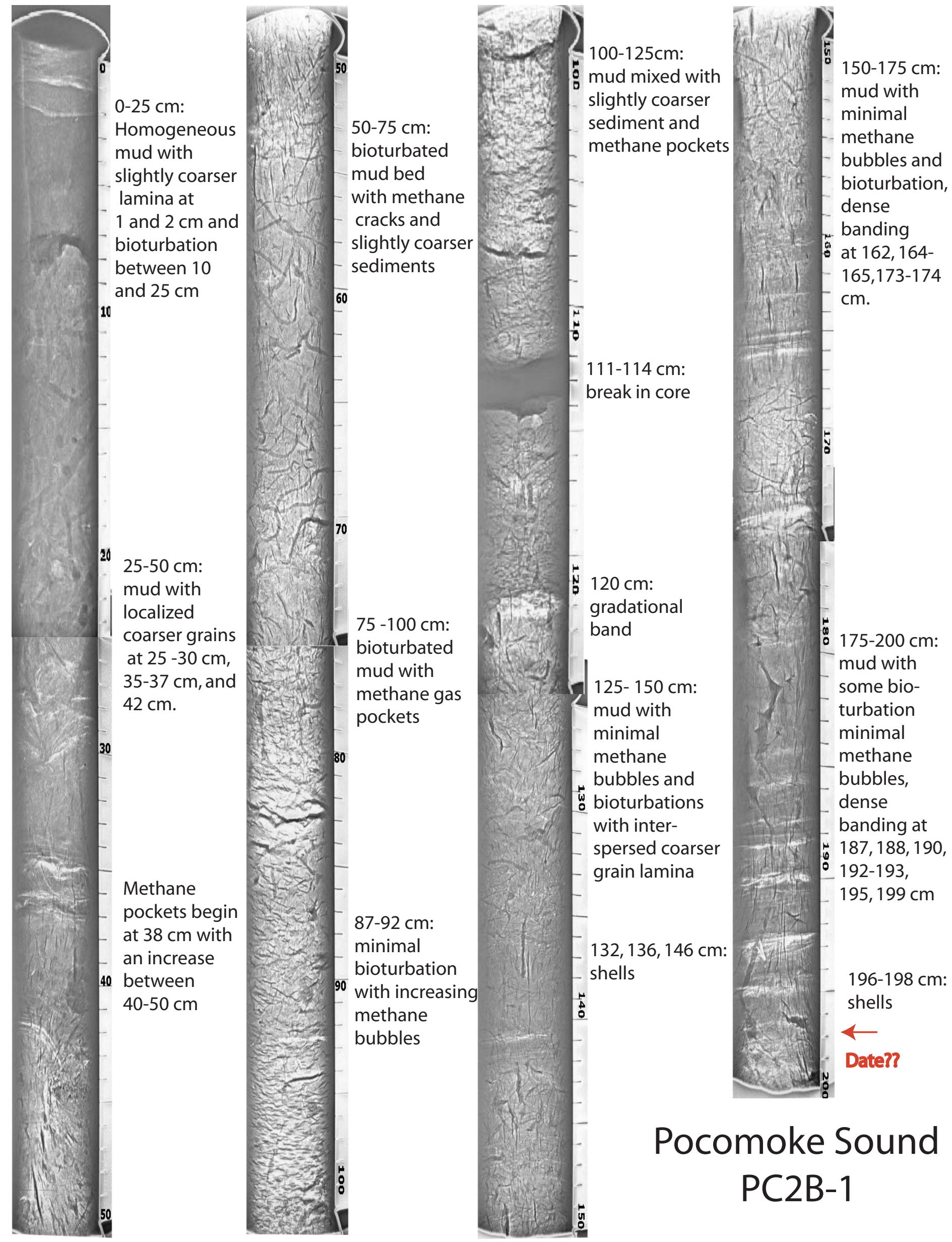

Figure 4.2. X-radiograph of core PC-2B-1, Pocomoke Sound, showing features such as methane bubbles, shells, sand layers, muds, and other lithologic features characteristic of Pocomoke Sound cores. 


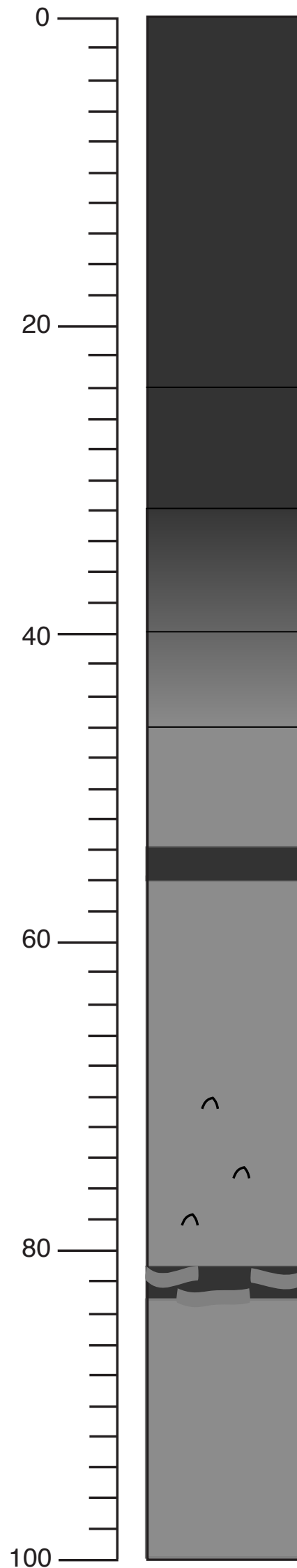

Medium gray clay with $\mathrm{cm}$ scale bands.

Grading to slightly lighter gray clay.

Lighter gray clay with a streaked darker band at $81-83 \mathrm{~cm}$ and sparse shell fragments.

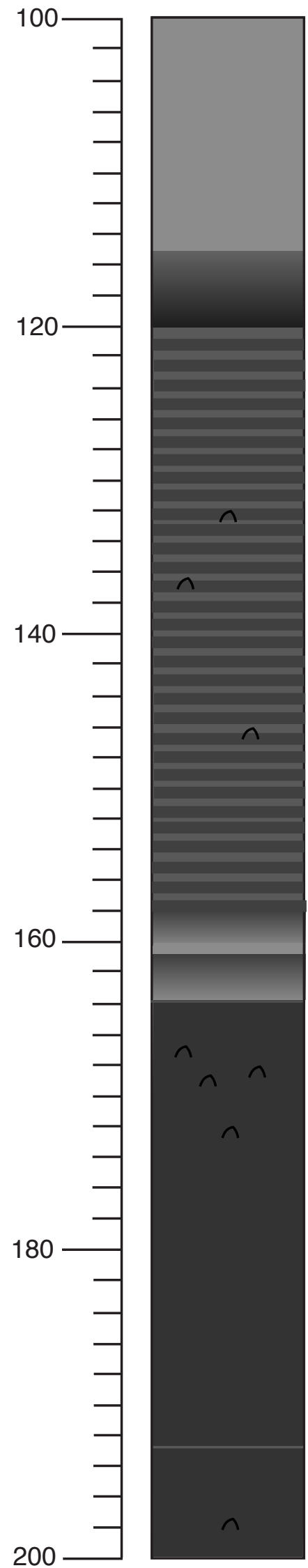

Gradational dark band.

Medium-light gray clay with continuous bands of medium gray clay and sparse shell fragments.

Two packages of grading medium gray bands

Medium gray clay with sparse shell fragments.

Thin ( $\mathrm{mm}$ scale) light-gray band

Pocomoke Core PC2B

Figure 4.3. Lithologic description of core PC-2B-1, with graphic rendering of $\mathrm{x}$-radiograph illustrated in Figure 4.2. 


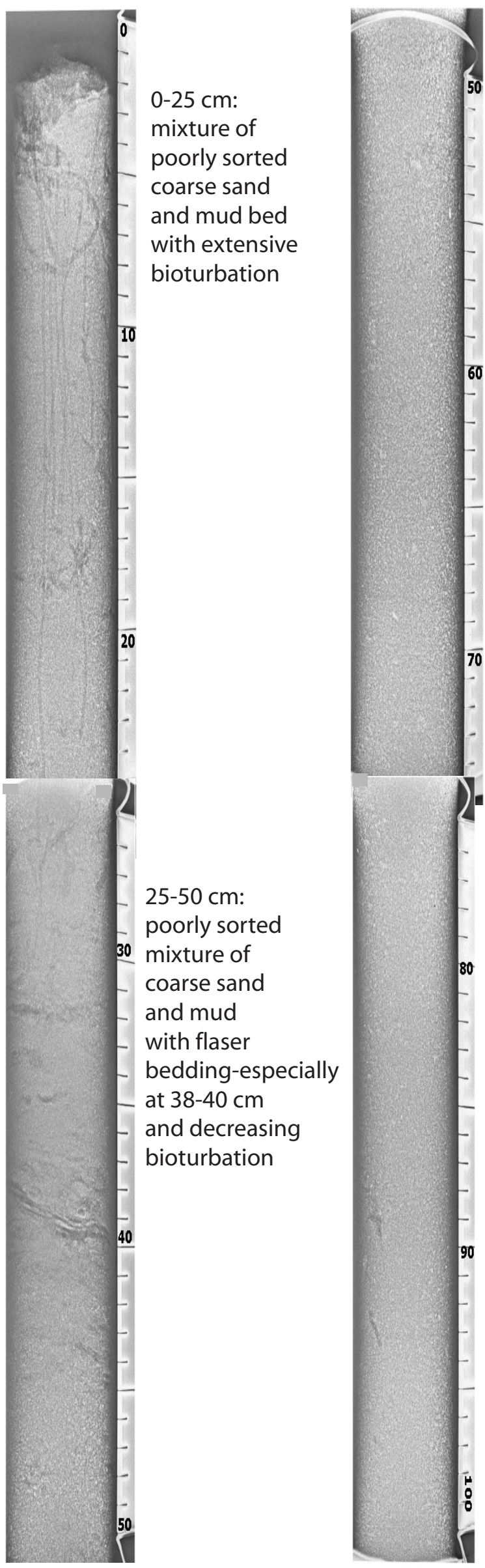

50-100 cm: poorly sorted mixture of coarse sand and mud with flaser bedding-especially at $86-90 \mathrm{~cm}$ and minimal bioturbation

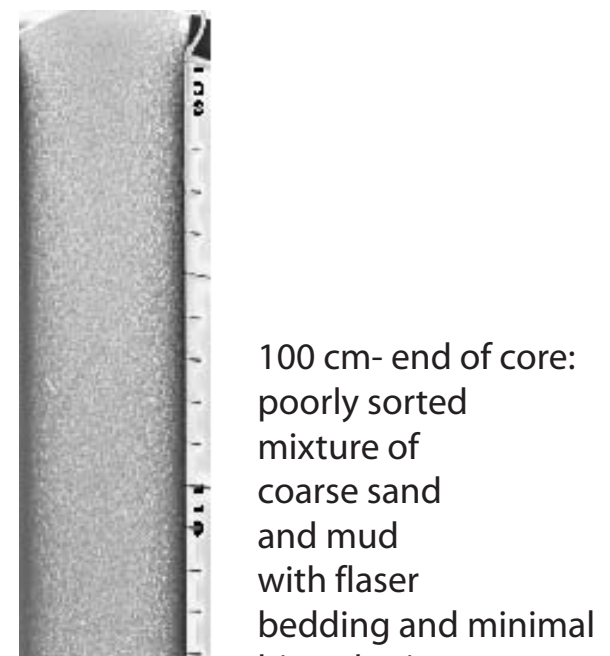
bioturbation
Pocomoke Sound

\author{
PC3A
}

Figure 4.4. X-radiograph of core PC-3A, from the flank of Pocomoke Sound. The core consists primarily of coarse sand and mud with flaser bedding, which do not typically preserve material suitable for either radiocarbon or lead-210 dating. Therefore, such cores were not used for paleoecological analyses. 


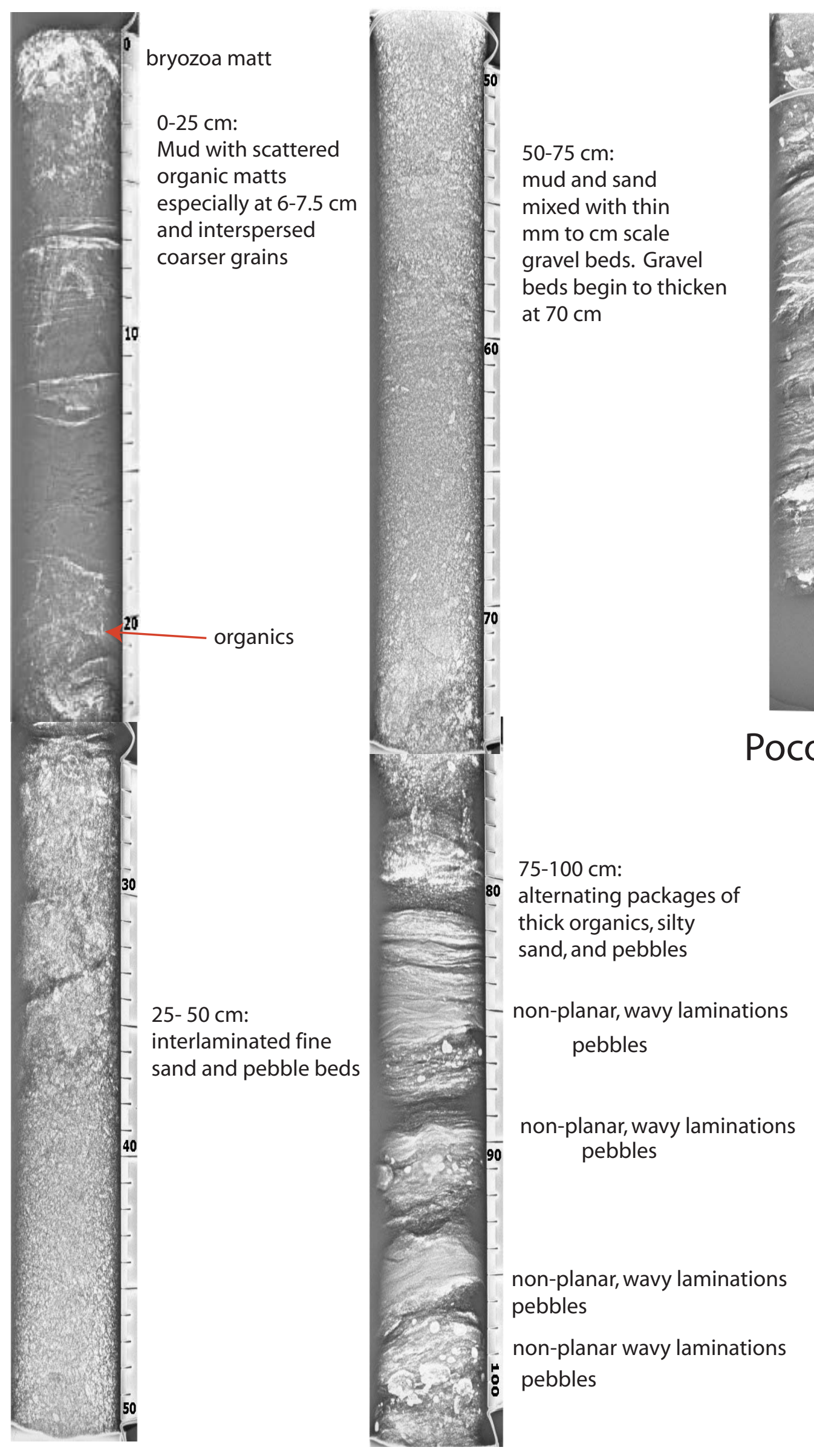

100-125 cm: packages of non-planar thick organics, silty sands, and coarse grains

PC4B

$75-100 \mathrm{~cm}$

alternating packages of

thick organics, silty

sand, and pebbles

non-planar, wavy laminations

pebbles

interlaminated fine

sand and pebble beds

Figure 4.5. X-radiograph of core PC-4B, Pocomoke Sound. The complex sedimentology and sedimentary history indicated at this site precluded any in-depth paleoecological analyses for this study. 
Table 4.1. Radiocarbon dates from Pocomoke Sound sediment cores

\begin{tabular}{|c|c|c|c|c|c|c|c|c|c|c|c|c|c|}
\hline 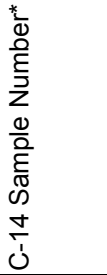 & 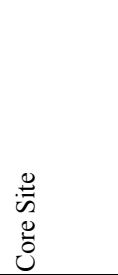 & 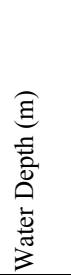 & 莺 & 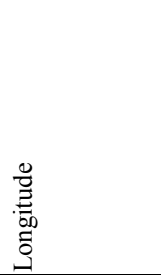 & 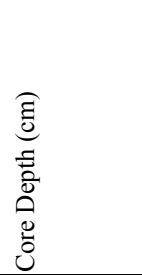 & 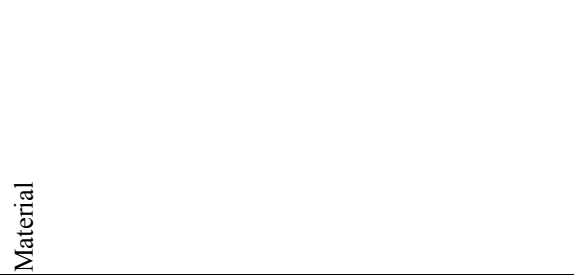 & $\begin{array}{l}\widetilde{0} \\
\stackrel{0}{0 D} \\
\stackrel{0}{\simeq}\end{array}$ & $\begin{array}{l}\frac{m}{U} \\
\frac{\pi}{0}\end{array}$ & 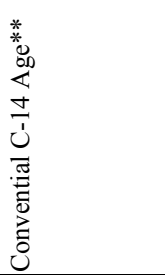 & 壹 & 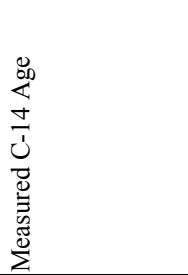 & 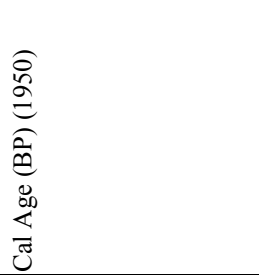 & 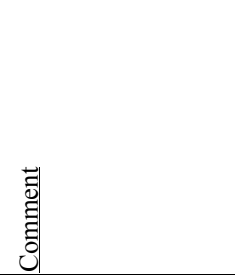 \\
\hline 157673 & PC2B-1 & 7.9 & $37^{\circ} 53.429$ & $75^{\circ} 48.408$ & $196-198$ & bivalves: frags., gastropod: whole/frags. & Pocomoke & -1.0 & $108.4 \mathrm{pMC}^{*}$ & $0.6 \mathrm{pMC}^{*}$ & $113.8 \mathrm{pMC}^{*}$ & too young & (post $1950 \mathrm{AD})$ \\
\hline 157674 & $\mathrm{PC} 3 \mathrm{~A}$ & 8.1 & $37^{\circ} 50.748$ & $75^{\circ} 49.138$ & $40-42$ & bivalves: shells, whole $\&$ frags, 1 gastropod fra & Pocomoke & -1.4 & $360 \mathrm{BP}$ & $40 \mathrm{BP}$ & $100.3 \mathrm{pMC}^{*}$ & too young & (post $1900 \mathrm{AD}$ ) \\
\hline 157675 & PC3B & 11.4 & $37^{\circ} 50.741$ & $75^{\circ} 48.745$ & $168-171$ & bivalve: frags. & Pocomoke & -3.3 & $126.9 \mathrm{pMC}^{*}$ & $0.6 \mathrm{pMC}^{*}$ & $132.8 \mathrm{pMC}^{*}$ & too young & (post $1950 \mathrm{AD}$ ) \\
\hline 157676 & PC4B & 27.3 & $37^{\circ} 48.300$ & $75^{\circ} 50.301$ & $30-32$ & bivalve::frag. gastropod: frags. & Pocomoke & -1.2 & $270 \mathrm{BP}$ & $40 \mathrm{BP}$ & $101.5 \mathrm{pMC}^{*}$ & too young & (post $1900 \mathrm{AD}$ ) \\
\hline 157677 & PC6B-2 & 14.6 & $37^{\circ} 44.910$ & $75^{\circ} 52.334$ & $150-152$ & bivalve: whole \& frags. & Pocomoke & -0.4 & $400 \mathrm{BP}$ & $40 \mathrm{BP}$ & $0 \mathrm{BP}$ & too young & \\
\hline 157678 & TR-1-D & 3.8 & $37^{\circ} 55.766$ & $75^{\circ} 46.868$ & $30-34$ & oyster: frags. & Pocomoke & -2.1 & $420 \mathrm{BP}$ & $40 \mathrm{BP}$ & $40 \mathrm{BP}$ & too young & \\
\hline 157679 & TR-2-D & 3.4 & $37^{\circ} 57.037$ & $75^{\circ} 43.516$ & $66-68$ & bivalve frags. \& whole, oyster: frags. & Pocomoke & -1.9 & $920 \mathrm{BP}$ & $40 \mathrm{BP}$ & $540 \mathrm{BP}$ & 518 & \\
\hline 161213 & PC6B-2 & 15.3 & $37^{\circ} 44.914$ & $75^{\circ} 52.334$ & $430-432$ & byrozoan & Pocomoke & -3.3 & $830 \mathrm{BP}$ & 40BP & $470 \mathrm{BP}$ & 470 BP (1950) & \\
\hline 161215 & PC6B-2 & 15.3 & $37^{\circ} 44.914$ & $75^{\circ} 52.334$ & $202-204 \mathrm{~A}$ & Mulinia lateralis & Pocomoke & 0.6 & $380 \mathrm{BP}$ & 40BP & 100.5p MC & too young $(1900)$ & (post $1900 \mathrm{AD}$ ) \\
\hline 161216 & PC6B-2 & 15.3 & $37^{\circ} 44.914$ & $75^{\circ} 52.334$ & 202-204B & gastropods & Pocomoke & -0.9 & $490 \mathrm{BP}$ & 40BP & $90 \mathrm{BP}$ & $110 \mathrm{BP}(1950)$ & \\
\hline 161217 & PC6B-2 & 15.3 & $37^{\circ} 44.914$ & $75^{\circ} 52.334$ & $450-458$ & Foraminifers (Elphidium ) & Pocomoke & 0 & $820 \mathrm{BP}$ & 40BP & $410 \mathrm{BP}$ & $460 \mathrm{BP}(1950)$ & \\
\hline 161218 & PC6B-2 & 15.3 & $37^{\circ} 44.914$ & $75^{\circ} 52.334$ & $434-442$ & Foraminifers (Elphidium ) & Pocomoke & 0 & $840 \mathrm{BP}$ & 40BP & $430 \mathrm{BP}$ & $480 \mathrm{BP}(1950)$ & \\
\hline 161220 & PC6B-2 & 15.3 & $37^{\circ} 44.914$ & $75^{\circ} 52.334$ & $146-148$ & Seven whole bivalves & Pocomoke & -0.3 & $490 \mathrm{BP}$ & 40BP & $80 \mathrm{BP}$ & 110 BP (1950) & \\
\hline 161219 & $\mathrm{PC} 2 \mathrm{~B}-3$ & 7.9 & $37^{\circ} 53.436$ & $75^{\circ} 48.410$ & 219 & Mulinia lateralis , whole \& frags. & Pocomoke & 0.1 & 107.2 BP & $0.5 \mathrm{pMC}$ & $112.9 \mathrm{pMC}$ & too young -1950 & (post $1900 \mathrm{AD}$ ) \\
\hline 161221 & PC2B-3 & 7.9 & $37^{\circ} 53.436$ & $75^{\circ} 48.410$ & 268 & Mulinia lateralis, whole & Pocomoke & -0.8 & $460 \mathrm{BP}$ & 40BP & $60 \mathrm{BP}$ & $60 \mathrm{BP}(1950)$ & \\
\hline 161222 & $\mathrm{PC} 2 \mathrm{~B}-3$ & 7.9 & $37^{\circ} 53.436$ & $75^{\circ} 48.410$ & $380-386$ & Mulinia lateralis, whole \& frags. & Pocomoke & -0.7 & $440 \mathrm{BP}$ & 40BP & $40 \mathrm{BP}$ & too young & (post $1900 \mathrm{AD}$ ) \\
\hline 161223 & $\mathrm{PC} 2 \mathrm{~B}-3$ & 7.9 & $37^{\circ} 53.436$ & $75^{\circ} 48.410$ & $452-454$ & Mulinia lateralis, whole & Pocomoke & -0.9 & $350 \mathrm{BP}$ & $40 \mathrm{BP}$ & $100.6 \mathrm{pMC}$ & too young $(1900)$ & (post $1900 \mathrm{AD}$ ) \\
\hline
\end{tabular}

* Date numbers are Beta Analytic

${ }^{* *} \mathrm{BP}=$ years before present $(1950) ; \mathrm{pMC}=\%$ modern carbon 


\section{Chapter 5. Temporal Trends in Benthic Microfossils in Pocomoke Sound: Implications for Water Quality}

T. M. Cronin* and A. Edwards**

*U.S. Geological Survey, Reston, Virginia 20192

**College of William and Mary, Williamsburg, Virginia 23187

\section{Introduction}

The impacts of post-colonial land-use change on the natural state of the Chesapeake Bay ecosystem has been documented through extensive paleoecological and geochemical analyses of fine-grained sediments from the mainstem bay. These "retrodictive" studies of ecosystem history include the application of a variety of proxies of ecosystem health such as diatoms (Cooper and Brush, 1991), foraminifera (Karlsen and others, 2000), dinoflagellates (Willard and others, 2003), ostracodes (Cronin and Vann, 2003), stable isotopes of sediments (Bratton and others, 2004), biogenic silica (Colman and Bratton, 2003), trace metals (Zheng and others, 2003), and organic biomarkers (Zimmerman and Canuel, 2000).

In addition to documenting the impacts of human activities, the sedimentary record of the bay has been instrumental in providing compelling evidence for the influence of climatological processes on water quality over various timescales. These studies demonstrate how regional precipitation influences freshwater river discharge, bay salinity, levels of dissolved oxygen, and turbidity over decadal and centennial timescales (Cronin and others, 2000; Karlsen and others, 2000; Cronin and Vann, 2003; Saenger and others, submitted). Moreover, these findings show that interannual and longer term variability in precipitation and river flow can exert dominant control over water quality, salinity, phytoplankton and submerged aquatic vegetation even in the absence of largescale land clearance, an observation consistent with growing evidence from instrumental records (e.g., Tyler, 1986; Malone, 1991; Harding and Perry, 1997; Gibson and Najjar, 2000; Orth and others, 2002). 
Due to their fine-grained lithology and rapid accumulation rates, sediments in the Pocomoke Sound channel also hold promise for reconstructing the faunal and water quality history of this region prior to $20^{\text {th }}$ century monitoring programs. This chapter describes temporal patterns in two calcareous microfossil groups, benthic foraminifers and ostracodes, and their paleoecological significance based on cores from Pocomoke Sound from sites PC-2B, PC-3B, and PC-6B. The three sites comprise a north-south transect running from the proximal part of the channel just west of Long Point, to its distal end south of Watts Island (Figure 5.1). The sites sample the main channel at water depths of 7.9, 11.4, and $15.3 \mathrm{~m}$, respectively, and thus provide a detailed history of the mesohaline region of Pocomoke Sound for the past several centuries.

\section{Material and Methods}

Table 5.1 lists site information for cores and the sampling information for foraminifera and ostracodes in each core. Both short $(\sim 200 \mathrm{~cm})$ and long $(\sim 450-500 \mathrm{~cm})$ cores taken in May and September 2001 were used in the study. Microfaunal samples were taken at either $2-\mathrm{cm}$ or $10-\mathrm{cm}$ spacing depending on the core. Between 30 and 50 grams of wet sediment were washed through $63-\mu \mathrm{m}$ sieves, oven dried and placed in vials. Approximately 100 specimens of each group were picked and from the $>150-\mu \mathrm{m}$ size fraction. The picking and analytical procedures for foraminifers and ostracodes are described in detail in Karlsen and others (2000) and Cronin and Vann (2003), respectively. Species were identified using the published literature and scanning electron photomicrographs provided in Cronin and others (1999, see www:http://pubs.usgs.gov/ pdf/of/of99-45/). Results are presented in terms of species' relative frequencies (the species' percent of the total assemblage from a sample), which are simply referred to as abundance.

The number of individual specimens used in quantitative microfaunal analyses depends on the objectives of the study, the abundance of the microfossils in the sediments and the time constraints. Time constraints limit the number of total samples one can reasonably analyze in a study, and there is a tradeoff between the number of specimens per sample and the number of samples and cores that can be studied. Our prior studies of Chesapeake Bay calcareous microfossils show that 100 specimens are usually sufficient 
to delineate primary trends in the major indicator species. For example, temporal variability in a species' abundance, which reflects major environmental parameters such as salinity and dissolved oxygen, can be extremely large due to the dynamic nature of the estuarine system. It is not unusual for the most common species in Chesapeake Bay to fluctuate between 10 and $>80 \%$ of the total assemblage within a core due to decadal to centennial changes in salinity, water quality, or both. Such variability is sufficiently large to obtain statistically significant confidence limits from which we can infer ecosystem change according to the statistical standards discussed by Buzas (1990). In

addition, Karlsen and others (2000) compared faunal trends using 100 and 300 individual foraminifers in the same Chesapeake Bay sediment core and found no appreciable difference in terms of major faunal patterns. Thus, we chose to conduct analysis of multiple cores, using 100 specimens from closely spaced samples (usually 2 to $10-\mathrm{cm}$ ). For example, we examined the ostracode faunal patterns at PC-2B-1 every 2-cm in the upper $200 \mathrm{~cm}$ of sediment and crosschecked these results with data sampled every $10-\mathrm{cm}$ from the upper $200 \mathrm{~cm}$ at PC-2B-3. A similar comparison of foraminifera from site PC6B was carried out. Using multiple cores from a single site permitted us to replicate the trends and establish whether compression or extension of the sediments occurred during the coring process. Comparing faunal records from multiple cores at different sites within Pocomoke Sound also provided a level of reproducibility and a confidence that observed faunal patterns are representative of the entire sound, rather than unique to a single site.

\section{Previous Studies of Chesapeake Bay Foraminifers and Ostracodes}

A large literature on the ecology of benthic foraminifers from Chesapeake Bay and its major tributaries provides the basic information for reconstructing ecosystem history from foraminiferal assemblages. Important prior studies include the papers by Robert Ellison of the University of Virginia and Maynard Nichols of Virginia Institute of Marine Science (Ellison and others, 1965; Ellison and Nichols, 1970; Ellison, 1972; Ellison and Nichols, 1976; Nichols and Norton, 1969; Ellison and others, 1986), and Martin A. Buzas of the Smithsonian Institution (Buzas, 1969, 1974). The ecology of 
Chesapeake Bay foraminiferal species is summarized in Table 5.2 (see Karlsen and others, 2000).

Although Chesapeake Bay ostracodes have received less attention than foraminifera, the classic study of ostracodes from the Patuxent River pier at Solomon Island, Maryland by Tressler and Smith (1948) was one of the earliest studies of ostracode seasonal ecology. Their study provides detailed seasonal ecology of some common species encountered throughout the bay region, and serves as a baseline faunal reference point for the lower Patuxent area prior to large-scale anthropogenic nutrient influx into the bay. Elliott and others (1966) also provided important ostracode data from the Rappahannock River estuary. More recently, Cronin and Vann (2003) examined ostracodes from a wide range of habitats throughout the bay region and applied species' ecological data to the paleoecological record from sediment cores. Their summary of ostracode ecology is given in Table 5.3.

In addition to describing microfaunal trends from Pocomoke Sound cores, the current chapter compares the Pocomoke Sound foraminiferal and ostracode records to those from the mesohaline region of the mainstem bay described in Karlsen and others (2000), Cronin and others (2000), Cronin and Ishman (2000), and Cronin and Vann (2003). In doing so, it allows us to make generalized conclusions about bay-wide faunal and ecosystem trends during the past few centuries.

\section{Results}

Foraminifera. Figure 5.2 illustrates trends in benthic foraminiferal species in cores PC2B-1, PC-3B-1, and PC-6B-1 for the upper $\sim 200 \mathrm{~cm}$ of the Pocomoke sedimentary record. The major features of the foraminiferal record are as follows:

- Two-step increase in Ammonia, most evident at $120-130 \mathrm{~cm}$ and 40-50 cm in PC2B-1, and in PC-3B.

- Increased Ammonia parkinsoniana coinciding with decreases in Elphidium.

- Increase in abundance of Ammobaculites, at about 20-30 cm core depth in all three cores; Ammobaculites is absent to sparse in the lower $150 \mathrm{~cm}$ of cores. 
- Miliammina fusca, a species that inhabits lower marsh habitats, is absent except in low numbers $\sim 120-150 \mathrm{~cm}$ core depth. This observation supports the conclusions of Chapter 3 that there has been minimal transport of foraminiferal, and other sand-sized material, from marshes bordering Pocomoke Sound to the central part of the sound over the past few centuries.

We also found several important foraminiferal events in the long core PC-6B-2. Most notable is the first stratigraphic appearance of Ammonia at $220 \mathrm{~cm}$; Ammonia increases in abundance in the upper $150 \mathrm{~cm}$ at PC-6B-1. Increased dominance of Ammonia in foraminiferal assemblages from the late $20^{\text {th }}$ century in other bay sites has been interpreted to signify environmental degradation related to oxygen depletion especially during the $20^{\text {th }}$ century (Karlsen and others, 2000). Such also seems to be the case in Pocomoke Sound. The other marker horizon identified in PC-6B-2 is the last stratigraphic appearance of Buccella frigida at $240 \mathrm{~cm}$; this species also occurred at 340, 350,400 , and $410 \mathrm{~cm}$ in this core. Based on the analysis of cores from the mainstem bay, Cronin and Ishman (2000) estimated that B. frigida became extinct in Chesapeake Bay about 500-600 years ago. With the exception of the single sample at $240 \mathrm{~cm}$, the foraminiferal data and radiocarbon dating (Chapter 4) from PC-6B-2 suggest that $B$. frigida also became extinct in the Pocomoke region perhaps several hundred years after disappearing from the central and northern bay.

Ostracodes. Figure 5.3, 5.4 and 5.5 illustrate temporal trends in 13 ostracode species in the three cores using 10-cm spaced samples. Notable ostracode faunal events include the following:

- Disappearance of A. captionis near $100-120 \mathrm{~cm}$

- Oscillations in the abundance of C. mexicana

- Increase, then decrease of C. curta near 110-120 cm in PC-2B-1, 150-80 cm in PC-3B1, and 60-70 cm in PC-6B-1

- Disappearance of C. newportensis at $150 \mathrm{~cm}$ in PC-2B-1 and $100 \mathrm{~cm}$ in PC-6B

- Increase in M. repexa in all three cores in the upper 50-60 cm 
- Decrease in P. brachyforma from $20-30 \%$ to sparse or absent in the upper $\sim 100$ $\mathrm{cm}$.

- Overall decrease in ostracode species diversity during $20^{\text {th }}$ century

Based on the encouraging results of the 10-cm spaced ostracode samples from the three short cores taken May 2001 and the high sedimentation rate and excellent chronology for site PC-2B (Chapters 3, 6), we chose to investigate temporal trends in ostracode assemblages at this site in more detail. Figure 5.6 compares patterns for six species in the upper $200 \mathrm{~cm}$ of PB-2B-1 (2-cm spacing) and PC-2B-3 (10-cm) showing very similar patterns of faunal variability in the two cores demonstrating the lack of any major compression or extension of the short or long piston cores during the coring process.

Figure 5.7 illustrates the combined 485-cm record from cores PC-2B-1 and PC2B-3 showing abundances of nine indicator species using the age model described in Chapter 6. The two dominant species, C. mexicana and P. brachyforma, exhibit an inverse relationship in terms of their relative frequencies over the past 250 years. $C$. mexicana dominates the Pocomoke Sound assemblages in the early 1800 s, briefly around 1900 , and again in the post-1930s period. This species is most common in polyhaline salinities in other Chesapeake Bay regions; P. brachyforma, which is dominant during three multi-decadal intervals centered around 1800, 1860 and 1920-30, is more common in mesohaline conditions of coastal bays and lagoons. Although salinity is most likely the primary factor causing the fluctuations of these two dominant species, $P$. brachyforma is also known to be a detrital feeder and decreased salinity caused by increased freshwater runoff would have been accompanied by increased input of fine particulate organic material from land-derived sources may have accompanied decreased salinity. The inflow of detrital material into Pocomoke Sound also probably increased during the $19^{\text {th }}$ century when extensive land clearance occurred in many parts of the Chesapeake watershed.

Secondary species inhabiting Pocomoke Sound prior to about 1950 include $A$. captionis, C. newportensis, Cytherura sp., L. nikraveshae and Loxoconcha sp. Many of these species disappear or decline in abundances in the early and mid- $20^{\text {th }}$ century, 
representing a decline in overall benthic species diversity. Twentieth century decline in diversity was also found off the Patuxent River mouth (Cronin and Vann, 2003).

After about 1950, the species C. curta appears abundantly for the first time in Pocomoke Sound channel, and this event is followed by an increase in M. repexa abundance around 1970. These species, which are rare to absent in Chesapeake Bay sediment cores as far back as 2000 years ago, are both tolerant of reduced oxygen levels and high turbidity.

\section{Discussion}

Resolving the issue of how human activity influenced Pocomoke Sound water quality was a primary objective of this study. Orth and others (2002) attempted to establish the long-term relationships in Pocomoke Sound between water quality (chlorophyll a, dissolved nitrogen and phosphorous, Secchi depth and total suspended solids) and SAV using data from the Chesapeake Bay Institute (CBI) for the period 19471980s and the Chesapeake Bay Program (CBP) from 1984-2000. The lack of CBI data prior to 1970 made it difficult to evaluate SAV coverage prior to the SAV decline of the 1960s known from anecdotal evidence. However, they were able to make the general conclusion that water quality appears to be worse for the 1984-2000 CBP monitoring period.

How and when human activity affected the ecosystem of Pocomoke Sound in particular, and Chesapeake Bay in general, can be addressed by comparing the microfaunal and paleoecological record of Pocomoke Sound to records available from the mesohaline region of the mainstem bay. Figures 5.8 and 5.9 plot four ostracode and two foraminiferal species in such a comparison, drawing on the excellent sedimentary records

from off the Patuxent River mouth and the north central bay channel off the Rhode River (Figure 5.1; RD/2209 and PTXT-2 core sites of Cronin and others, 2000; Karlsen and others, 2000; Cronin and Vann, 2003). For the PTXT-2 site, data from two gravity cores and one piston core are shown in Figure 5.8 for the important species C. curta and $M$. repexa. The Pocomoke Sound ostracode data are those from the PC-2B site; the foraminiferal data in Figure 5.9 are taken from PC-2B-1 and PC-6B-1 short cores. 
Figure 5.8 shows that most major faunal changes that occurred in the mainstem bay during the mid-to late $20^{\text {th }}$ century also occurred in Pocomoke Sound, although they may have occurred slightly later at the PTXT-2 site. These changes include a progressive decrease and ultimate disappearance of $C$. newportensis, fluctuations and the ultimate disappearance of $P$. brachyforma, an increase in C. curta, and subsequent increase in $M$. repexa, a species found in the uppermost $5-10 \mathrm{~cm}$ of sediment from almost all sites cored in the bay. Other faunal changes, such as the disappearance of A. captionis around 1900, also occur in other regions of the bay.

Figure 5.9 shows the temporal trends in two indicator foraminiferal species (Ammonia parkinsoniana, Ammobaculites salsum) during the $20^{\text {th }}$ century in two Pocomoke Sound cores (PC-2B-1, PC-6B-1) compared with trends observed in the central mainstem bay at core sites RD98/2209 and PTXT-2P5. Despite different core locations, water depths, salinity regimes, and other physical and chemical conditions, all sites show generally similar patterns in Ammonia abundance. There is a progressive (though not uniform) increase in its relative frequency starting in the in the 1940-50s, reaching its greatest abundance in the 1980s and later. Increasing abundance of Ammonia was accompanied by deformed shell morphologies in the mid-bay; both trends were attributed to greater hypoxia during the post-1960s interval (Karlsen and others, 2000). The difference in abundances from site to site can be accounted for by other environmental factors, such as salinity. For example, the lowest abundances of Ammonia occur at RD98/2209, which is located in the channel of the mainstem at $25 \mathrm{~m}$ water depth has a mean salinity of 20-22 ppt, in contrast to lower salinity at the other sites. Regional differences in the levels of oxygen depletion might also be a factor in the variable dominance of this species.

Ammobaculites is a dominant species that today inhabits organic-rich, finegrained sediments along the margins of Chesapeake Bay in lower mesohaline salinities. It does not typically inhabit mesohaline and polyhaline environments of the open bay such as the regions where our sediment cores are located. In contrast to results for Ammonia, trends in Ammobaculites are characterized by rare, intermittent occurrences in Pocomoke Sound and the mainstem bay (Figure 5.9). It is possible that this species only inhabits the open waters of the bay during brief periods when organic-rich pulses of 
sediment are discharged into the bay due to local climatological and hydrological processes or land use change processes.

The timing of faunal changes observed in the mainstem and Pocomoke Sound paleoecological records (Figures 5.8 and 5.9) raises the important issue as to whether $20^{\text {th }}$ century ecosystem degradation was synchronous throughout the bay, or whether local land-use histories exerted a greater influence on adjacent bay habitats. Several processes that introduce uncertainty in the chronology of the sedimentary record, which leads to uncertainty in correlation among core sites and might explain small age discrepancies in the major faunal events. These processes include temporally variable sedimentation rates at a site, bioturbation and mixing of sediments by benthos, analytical error in radioisotopic dating, different sampling intervals for each core, and low microfaunal abundance in some core intervals. These factors combine to produce a potential uncertainty of about 10-20 years for the upper $100-200 \mathrm{~cm}$ of sediment at most core sites where sedimentation rates are $\sim 1 \mathrm{~cm} \mathrm{yr}^{-1}$. Pending further paleoecological and radioisotopic dating of cores from regions with high sedimentation rates, it can be stated nonetheless that trends in foraminiferal and ostracode species with well-known ecological requirements provide strong evidence that $20^{\text {th }}$ century land-use changes altered the functioning of the Chesapeake Bay ecosystem from its natural state across a wide range of salinities ( $<10$ to $>22 \mathrm{ppt})$. Many changes in benthic communities were nearly synchronous throughout the bay within the limits of the available dating, although different regions of Chesapeake Bay may have been affected more than others.

\section{Conclusions}

The data presented above allows the following conclusions regarding the ecosystem history of Pocomoke Sound.

1) The middle to late $20^{\text {th }}$ century saw unprecedented changes in the benthic assemblages of both ostracodes and foraminifera in Pocomoke Sound that can be attributed to degradation in water quality. The increased abundance of Ammonia parkinsoniana and Cytheromorpha curta in the 1940-50s, followed by further increases in Ammonia and increases in Ammobaculites and 
Megacythere repexa in the 1970-80s, signify a two-phase shift in the ecosystem. These changes represent perturbations to the natural variability in faunal assemblages, which are normally driven by climatically influenced changes in salinity regimes. Changes in late $20^{\text {th }}$ century benthic communities included the rise to dominance of facultative anaerobic and detrital feeding species tolerant of hypoxia, increased influx of organic matter, and increased turbidity.

2) As environmentally tolerant species became numerically dominant in the Pocomoke Sound and other mesohaline and polyhaline regions of the bay, several species that had inhabited the bay for millennia became extinct between 1900 to 1950 in many regions.

3) Comparison of the Pocomoke paleoecological record with those from elsewhere in Chesapeake Bay provide strong evidence that environmental degradation during the $20^{\text {th }}$ century was nearly synchronous bay-wide within the limits of sediment core chronology(10-20 years). The evidence available so far indicates that bay-wide changes occurred from the Rhode River region of the mainstem in the north, to Pocomoke Sound in the south. These results suggest that the impacts of $20^{\text {th }}$ century land-use changes were felt throughout the bay, regardless of local land-use history.

4) Although the current study did not focus specifically on epiphytal species that inhabit shallow water grasses such as Zostera, our results support the hypothesis of Orth and others (2002, see also Orth and Moore, 1983) that unprecedented changes to the bay ecosystem affected submerged aquatic vegetation in the Tangiers-Pocomoke region prior to large-scale monitoring began in the 1970s and 80s. It is highly likely environmental changes that affected the channel of Pocomoke Sound would have also had severe impacts on the adjacent shallow water regions of Pocomoke Sound. It is not clear whether water quality changes were due directly to land use change in the local Pocomoke watershed or whether they were connected to broader changes in the bay and its watershed and estuarine circulation. 


\section{Acknowledgements}

We are grateful to Captain Rick Younger for his stewardship of the R/V Kerhin during coring, Jeffrey Halka and Carl Hobbs, III for guidance on Pocomoke Sound stratigraphy and sedimentation, Christopher Nytch, Cheryl Eberth, and Meredith Robertson for assistance with sample processing.

\section{Reference Cited}

Bratton, J. F., Colman, S. M., and Seal, R. R. II, 2004, Eutrophication and carbon sources in Chesapeake Bay over the last 2700 years: Human impacts in context: Geochimica et Cosmochimica Acta, v. 67, No. 13, p.

Buzas, M. A., 1969, Foraminiferal species densities and environmental variables in an estuary: Limnology and Oceanography, v. 14. p. 411-422.

Buzas, M. A., 1974, Vertical distribution of Ammobaculites in the Rhode River, Maryland: Journal of Foraminiferal Research, v. 4, p. 144-147.

Buzas, M. A., 1990, Another look at confidence limits for species proportions: Journal of Paleontology, v. 64, p. 842-843.

Colman, S.M., and Bratton, J.F., 2003, Anthropogenically induced changes in sediment and biogenic silica fluxes in Chesapeake Bay: Geology, v. 31 (1), p. 71-74.

Cooper, S. R. and. Brush, G. S., 1993, A 2,500 year history of anoxia and eutrophication in Chesapeake Bay: Estuaries, v. 16, p. 617-626.

Cronin, T. M., Kamiya, T., Dwyer, G. S., Belkin, H., Vann, C., Schwede, S., Wagner, R. S., in press, Ecology and shell chemistry of Loxoconcha matagordensis: Palaeogeography, Palaeoclimatology, Palaeoecology. 
Cronin, T. M., Wagner, R. S., Slattery, M., eds., 1999, Microfossils from Chesapeake Bay sediments: Illustrations and species database: USGS Open-file Report 99-45. (available on WWW: http://pubs.usgs.gov/pdf/of/of99-45/).

Cronin, T. M., Willard, D. A., Kerhin, R. T., Karlsen, A. W., Holmes, C. W., Ishman, S, Verardo, S., McGeehin, J., and Zimmerman, A., 2000, Climatic variability over the last millennium from the Chesapeake Bay sedimentary record: Geology, v. 28, p. 3-6.

Cronin. T. M., and Ishman, S. E., 2000, Holocene Paleoclimate from Chesapeake Bay based on Ostracodes and Benthic Foraminifera from Marion-Dufresne core MD99-2209. Ch. 10 USGS Open-file Report 00-306, p. 93-101.

Cronin, T. M. and Vann, C., 2003, The sedimentary record of anthropogenic and climatic influence on the Patuxent Estuary and Chesapeake Bay ecosystems: Estuaries, v. 26, no. 2a, p. 196-209.

Elliott, H. A., Ellison, R., and Nichols, M. M., 1966, Distribution of recent Ostracoda in the Rappahannock Estuary, Virginia: Chesapeake Science, v. 7, p. 203-207.

Ellison, R. L., 1972, Ammobaculites, a foraminiferal proprieter of Chesapeake Bay estuaries: Geological Society of America Bulletin, v. 133, p. 247-262.

Ellison, R. L., Broome, R., and Ogilvie, R., 1986, Foraminiferal response to trace metal contamination in the Patapsco River and Baltimore Harbour, Maryland: Marine Pollution Bulletin, v. 17, p. 419-423.

Ellison, R. L., and Nichols, M. M., 1970, Ecology of foraminifera from the Rappahannock Estuary, Virginia: Cushman Foundation for Foraminiferal Research Contributions, v. 21, p. 1-17.

Ellison, R. L., and Nichols, M. M., 1976, Modern and Holocene foraminifera in the Chesapeake Bay region, in International Symposium on Benthonic Foraminifera of Continental Margins, Part A. Maritime Sediments Special Publication No. 1. p. $131-151$

Ellison, R. L., Nichols, M. M., and Hughes, J., 1965, Distribution of recent foraminifera in the Rappahannock River Estuary: Virginia Institute of Marine Science Special Science Report, no. 47, p. 1-35. 
Gibson, J. R., and Najjar, R. G., 2000, The response of Chesapeake Bay salinity to climate-induced changes in streamflow: Limnology and Oceanography, v. 45, (8), p. 1764-1772.

Harding, L. W., Jr., and Perry, E. S., 1997, Long-term increase in phytoplankton biomass in Chesapeake Bay, 1950-1994: Marine Ecology Progress Series, v. 157, p. 3952.

Karlsen, A.W., Cronin, T. M., Ishman, S. E., Willard, D. A., Holmes, C. W., Marot, M. and Kerhin, R., 2000, Historical trends in Chesapeake Bay dissolved oxygen based on benthic foraminifera from sediment cores: Estuaries, v. 23 (4), p. 488508.

Malone, T. C., 1991, River flow, phytoplankton production and oxygen depletion in Chesapeake Bay, in Tyson, R. V., and Pearson, T. H. eds., Modern and Ancient Continental Shelf Anoxia, Geological Society Special Paper 58. p. 83-93.

Nichols, M. M., and Norton, W., 1969, Foraminiferal populations in a coastal plain estuary: Palaeogeography, Palaeoclimatology, Palaeoecology, v. 6, p. 197-213.

Orth, R. R., and Moore, K. A., 1983, Chesapeake Bay: An unprecedented decline in submerged aquatic vegetation: Science, v. 222, p. 51-53.

Orth, R. R., Moore, K., Fishman, J., Wilcox, D., Karrh, L., and Parham, T., 2002, Causes of submerged aquatic vegetation declines in Tangiers Sound, Chespapeake Bay: Chesapeake Bay Program Report, 133 p.

Saenger, C., Cronin, T. M., Thunell, R., and Vann, C., submitted, Modeling River Discharge, Precipitation, and Estuarine Salinity: Application to Holocene Paleoclimate History. The Holocene.

Tressler, W. L. and Smith, E. M., 1948, An ecological study of seasonal distribution of Ostracoda, Solomons Island, Maryland, region: Chesapeake Biological Laboratory Publication No. 71, 61 p.

Tyler, M. A., 1986, Flow-induced variation in transport and deposition pathways in the Chesapeake Bay: the effect on phytoplankton dominance and anoxia, in Wolfe, D. A., ed., Estuarine Variability, Orlando, Academic Press, p. 161-175. 
Willard, D. A., Cronin, T. M., and Verardo. S., 2003, Late Holocene climate and ecosystem variability from Chesapeake Bay sediment cores: The Holocene, v. 13, no. 2, p. 201-214.

Zheng, Y., Weinman, B., Cronin, T. M., Fleisher, Q., and Anderson, R. F., 2003, A rapid procedure for thorium, uranium, cadmium, and molybdenum in small sediment samples by inductively coupled plasma-mass spectrometry: application in Chesapeake Bay: Applied Geochemistry, v. 18, p. 539-549.

Zimmerman A. R., and Canuel, E. A., 2000, A geochemical record of eutrophication and anoxia in Chesapeake Bay sediments: anthropogenic influence on organic matter composition: Marine Chemistry, v. 69, p. 117-137. 
PC2-B

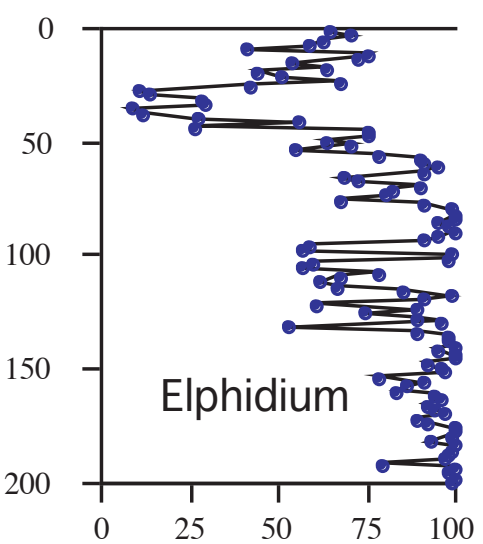

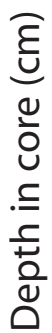

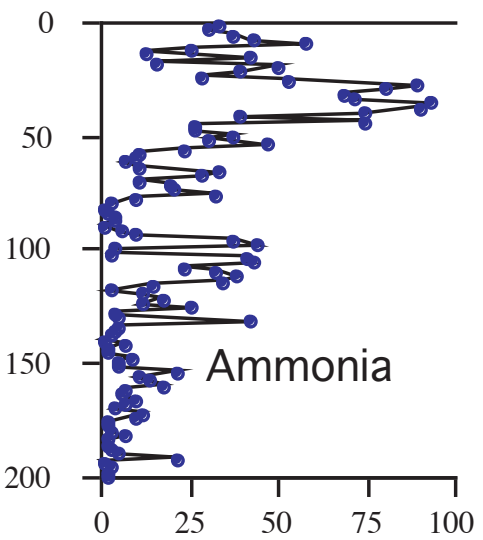

PC3-B
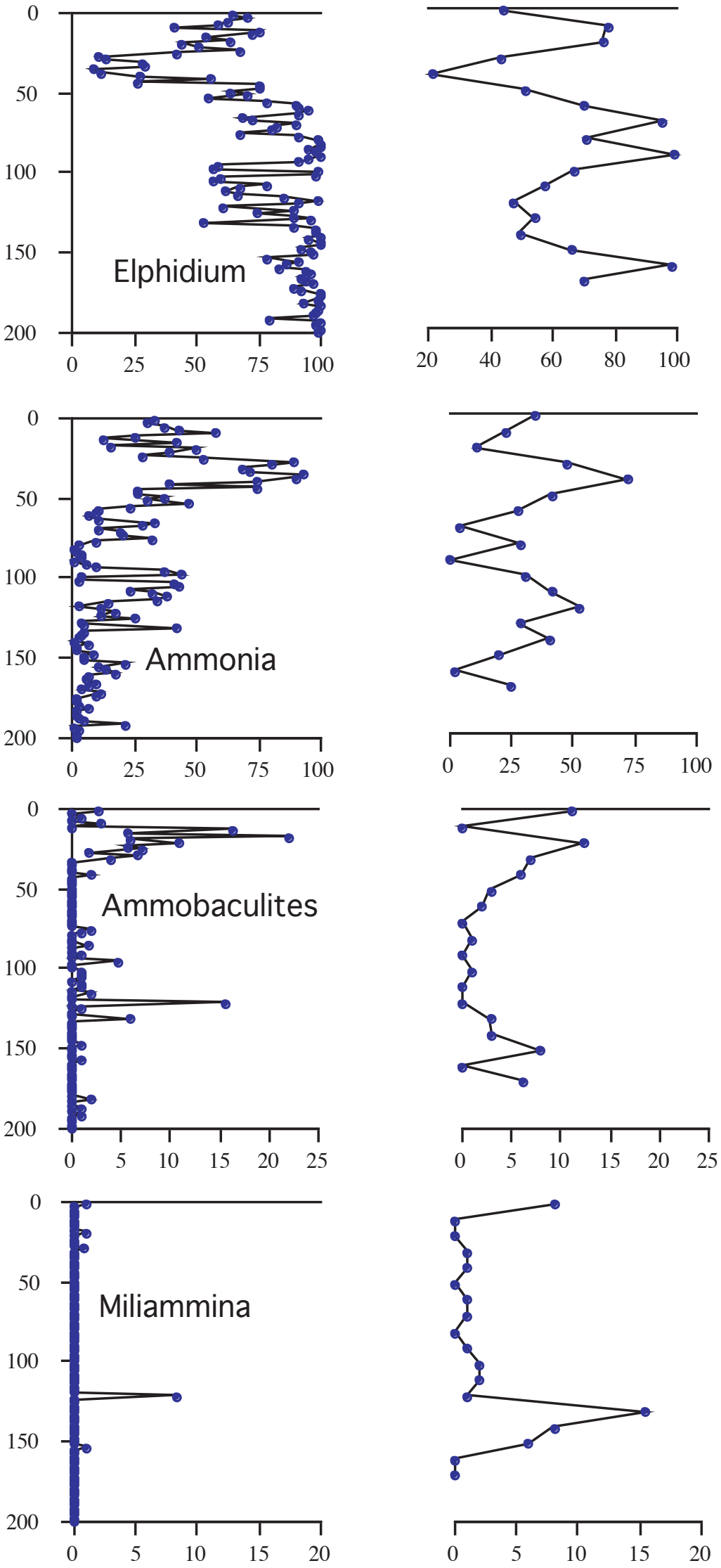

PC6-B
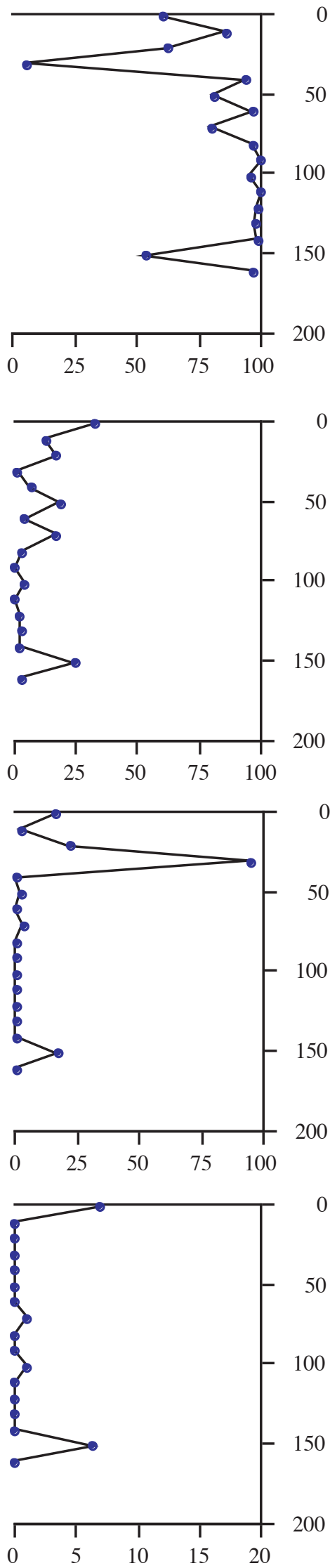

percent total assemblage

Figure 5.2. Relative frequencies (percentages) of four foraminiferal genera in Pocomoke Sound sediment cores. 
PC2-B
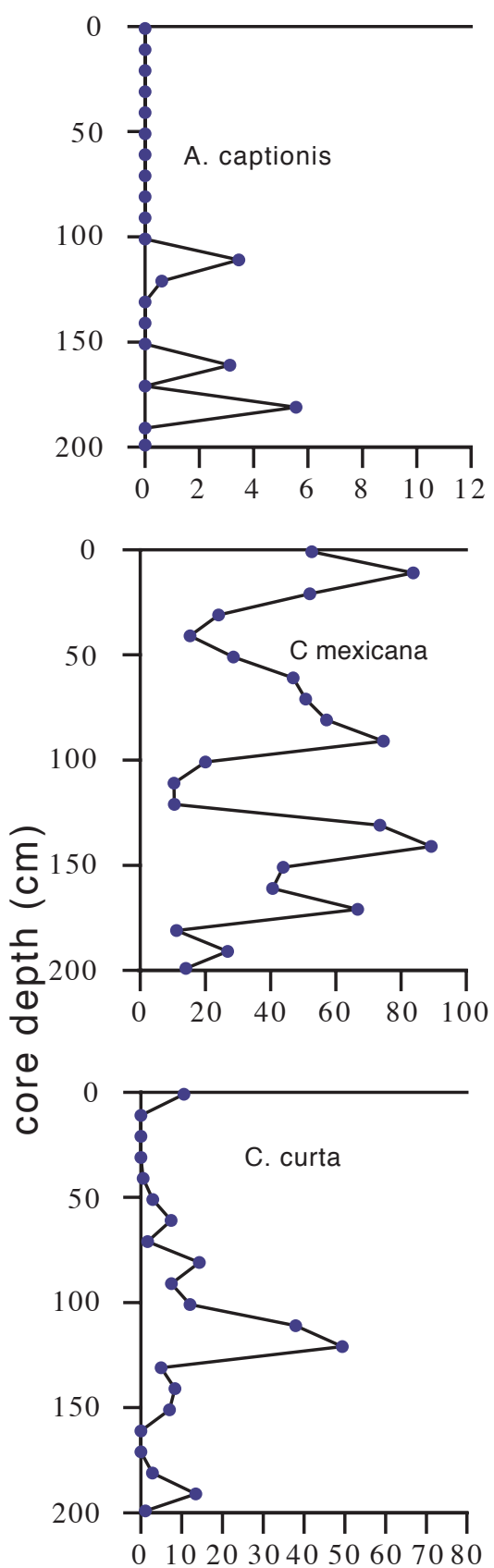

$0 \quad 1020304050607080$

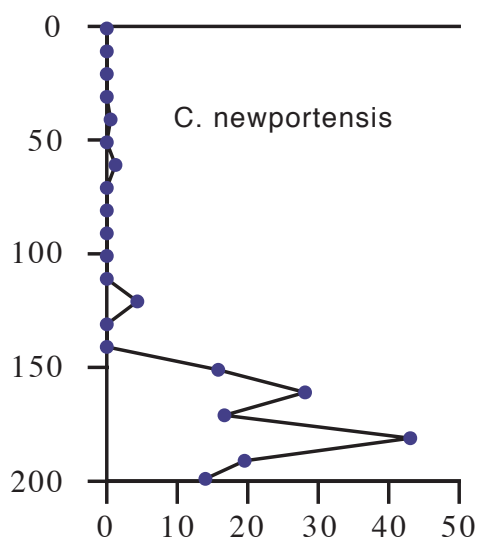

PC3-B
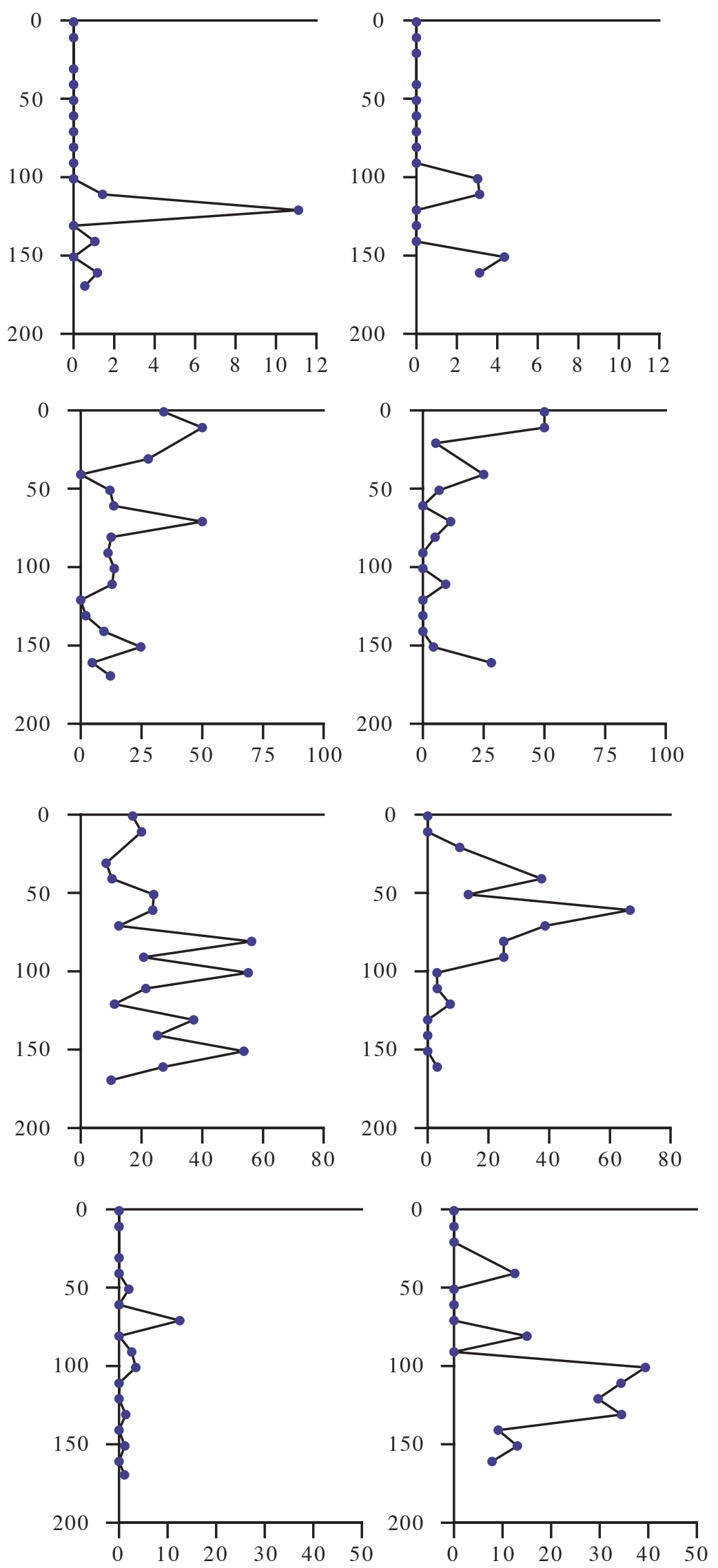

percent total assemblage

Figure 5.3. Relative frequencies (percentages) of four ostracode species in Pocomoke Sound sediment cores. 
PC2-B
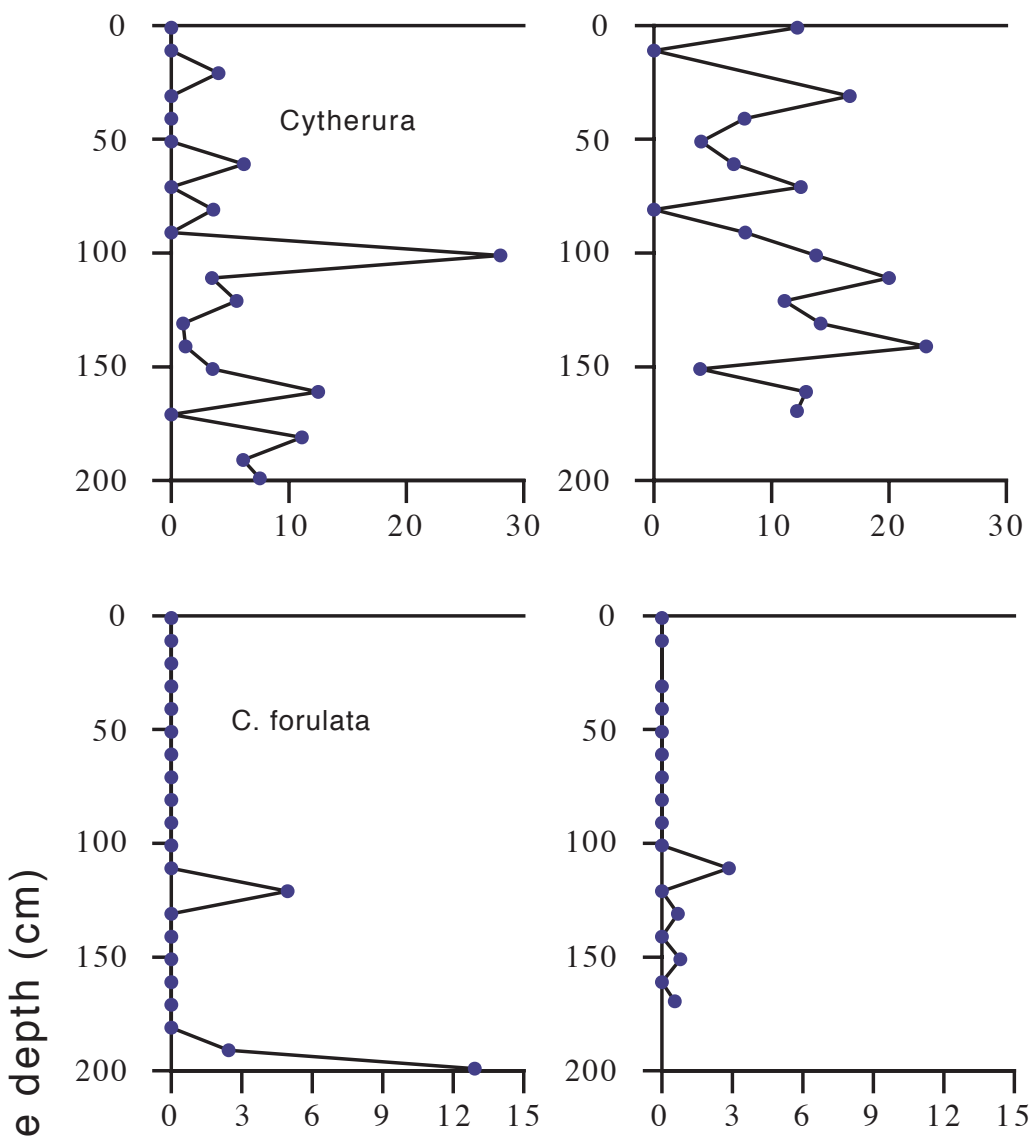

1
0
0
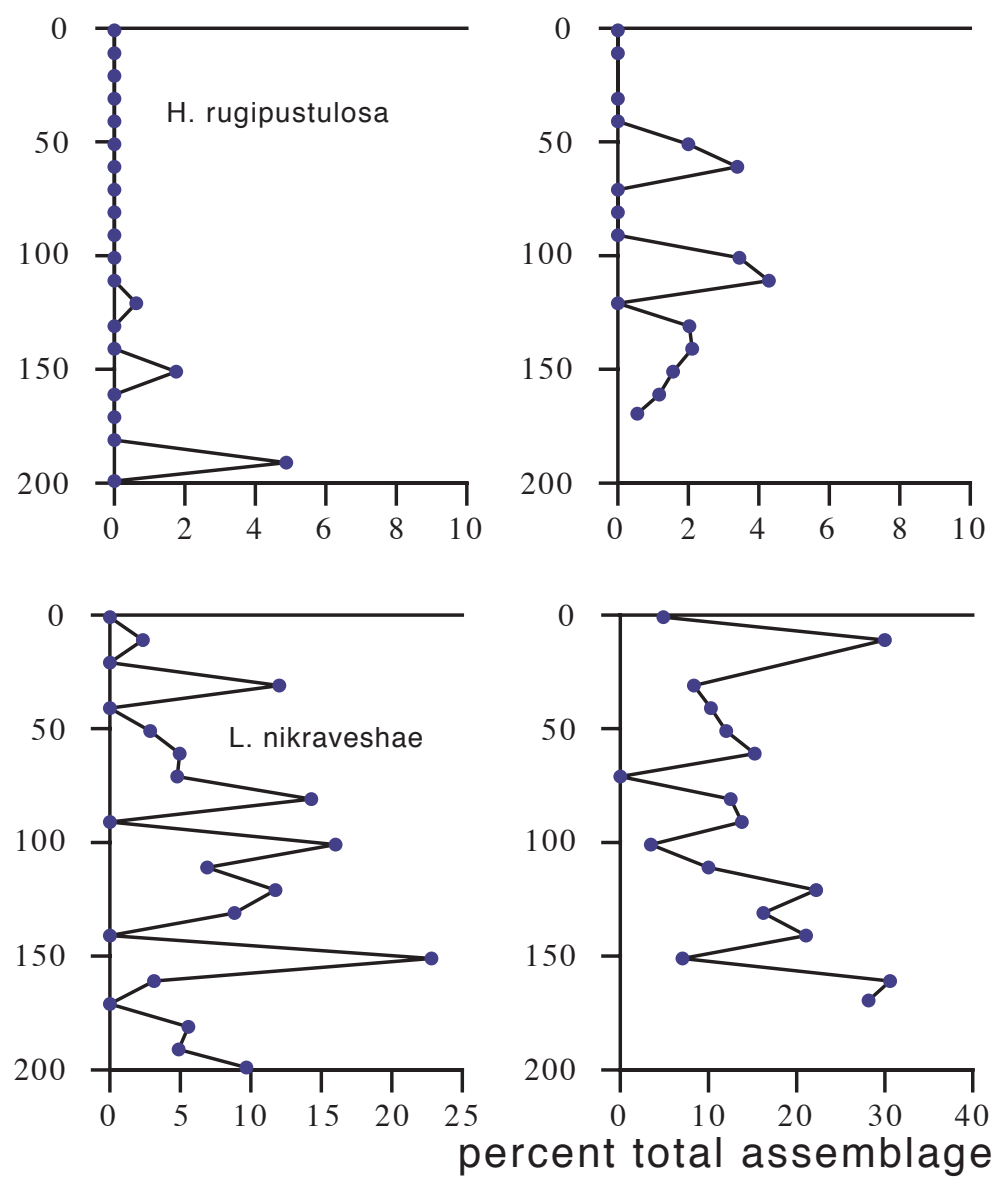

PC6-B
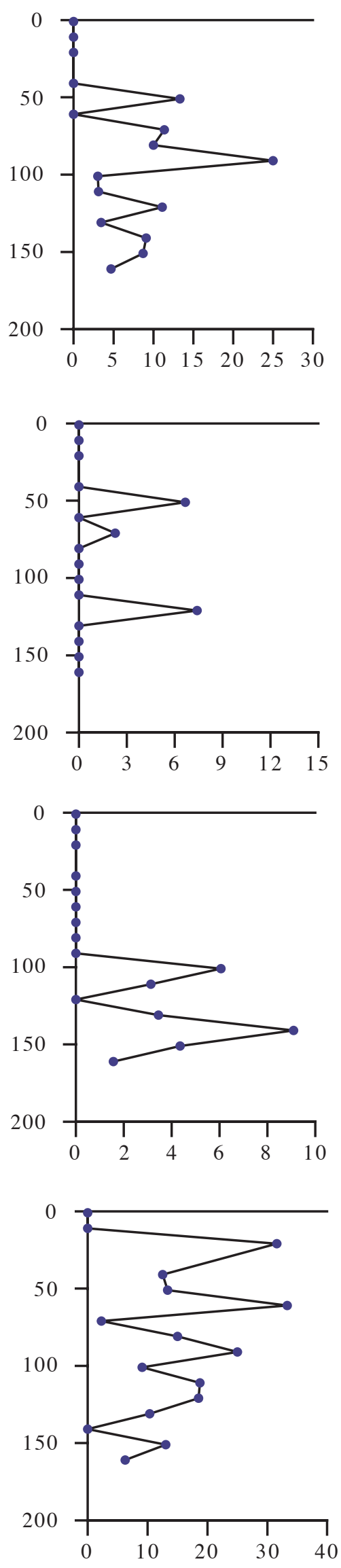

Figure 5.4. Relative frequencies (percentages) of four ostracode species in Pocomoke Sound 
PC2-B
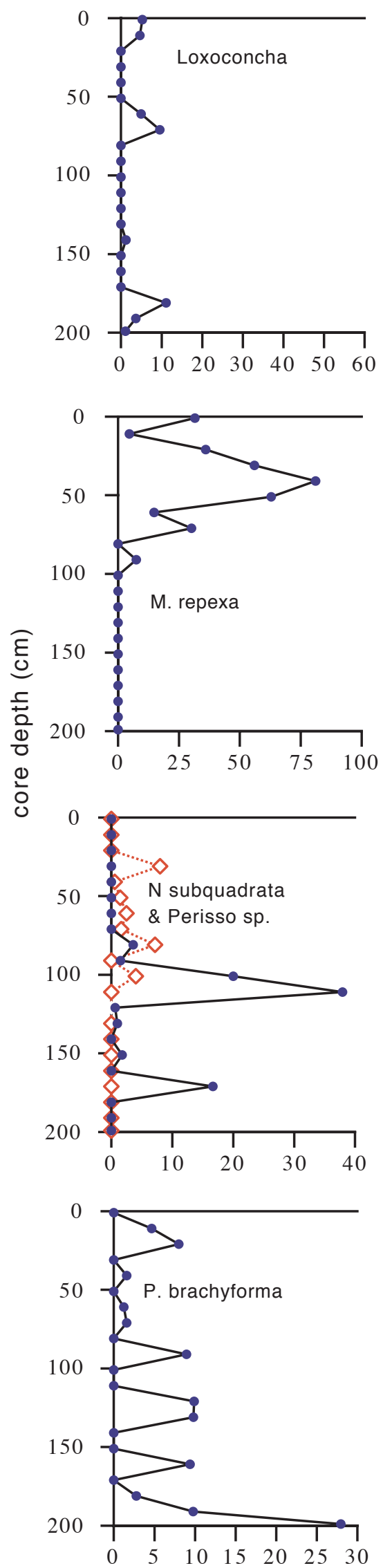

PC3-B
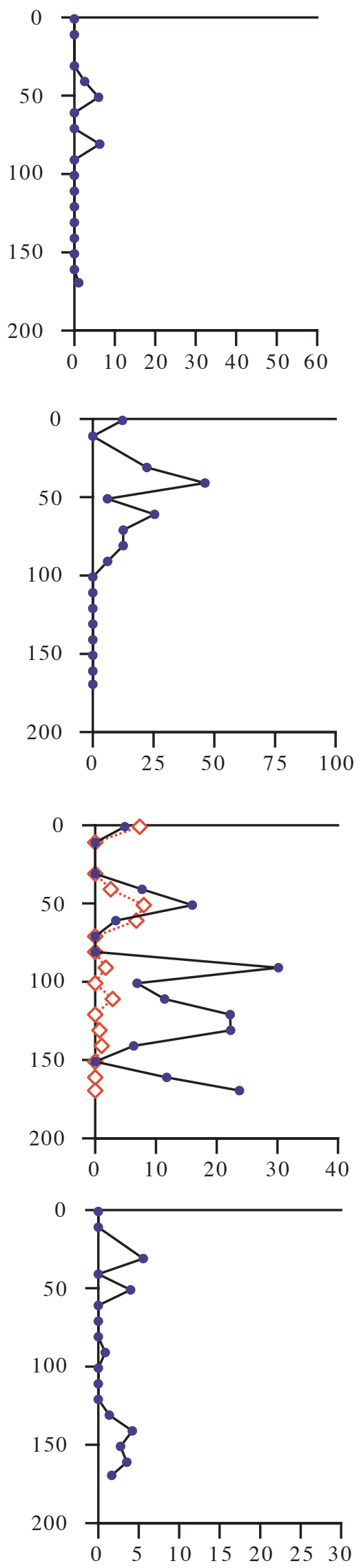

PC6-B
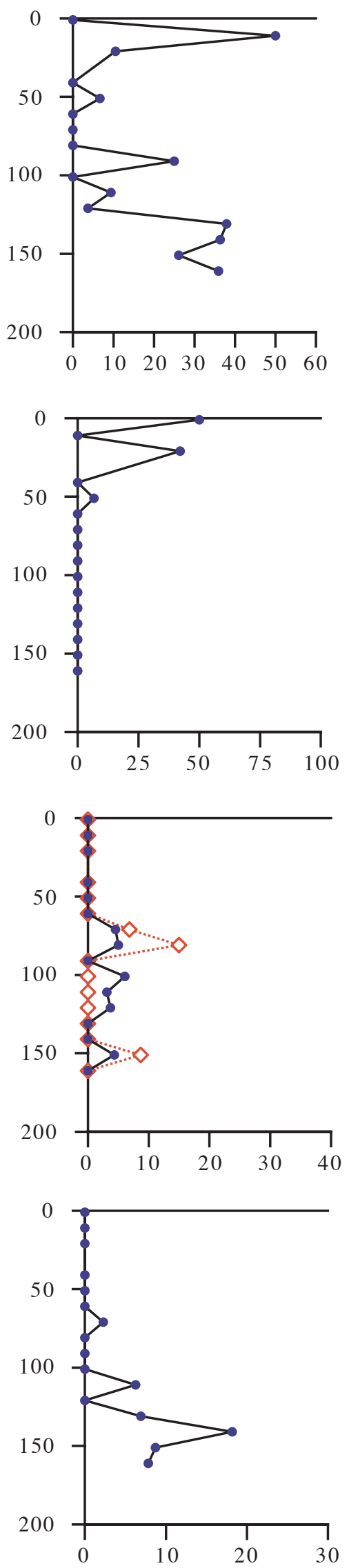

\section{percent total assemblage}

Figure 5.5. Relative frequencies (percentages) of five ostracode species in Pocomoke Sound sediment cores. Open diamonds are Perissocytheridea. 

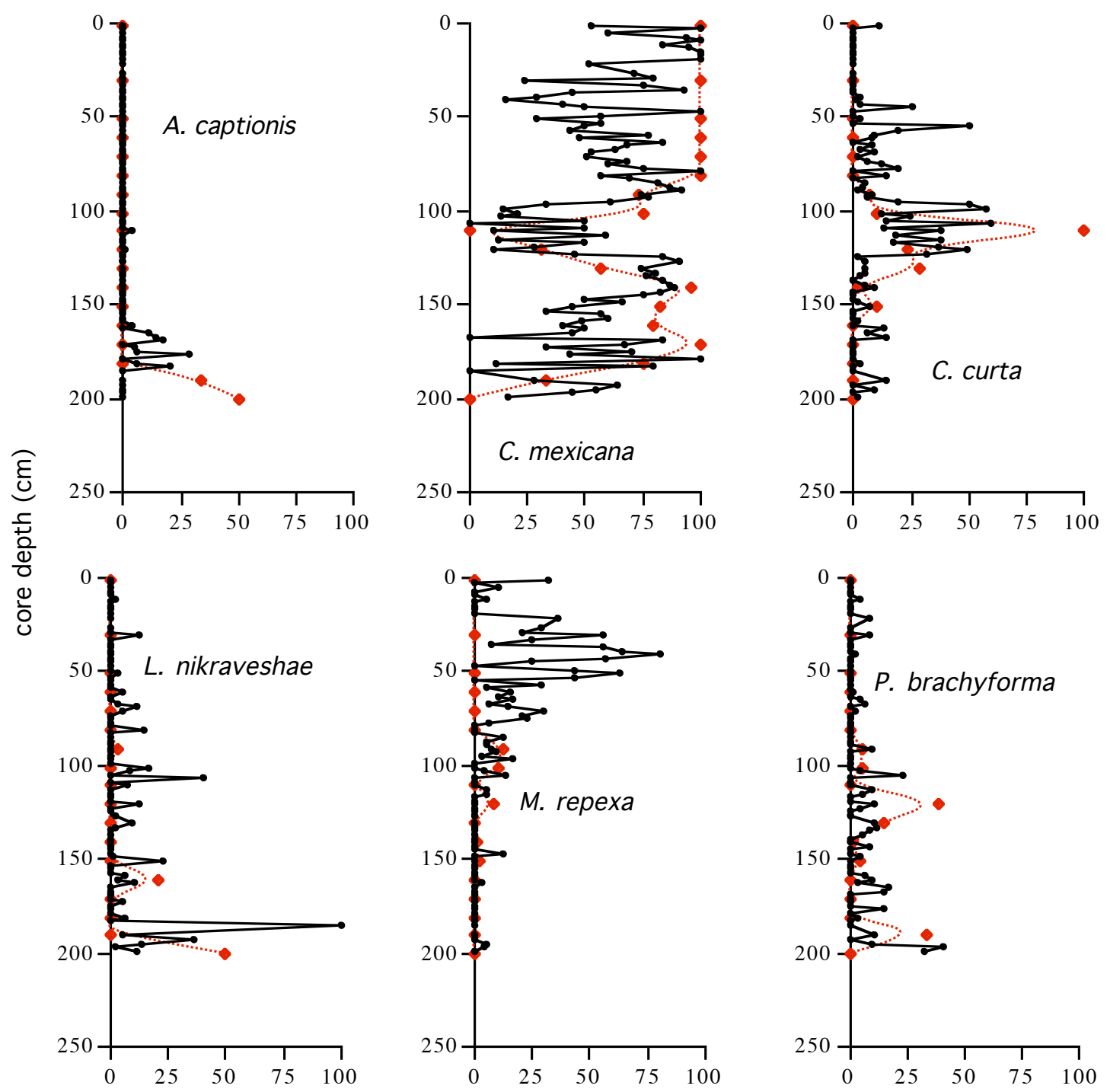

percentage (relative frequency total assemblage)

Figure 5.6. Comparison of ostracode patterns in cores PC2-B1 and PC2-B3. Red = PC-2B-3, black - PC-2-B-1. 

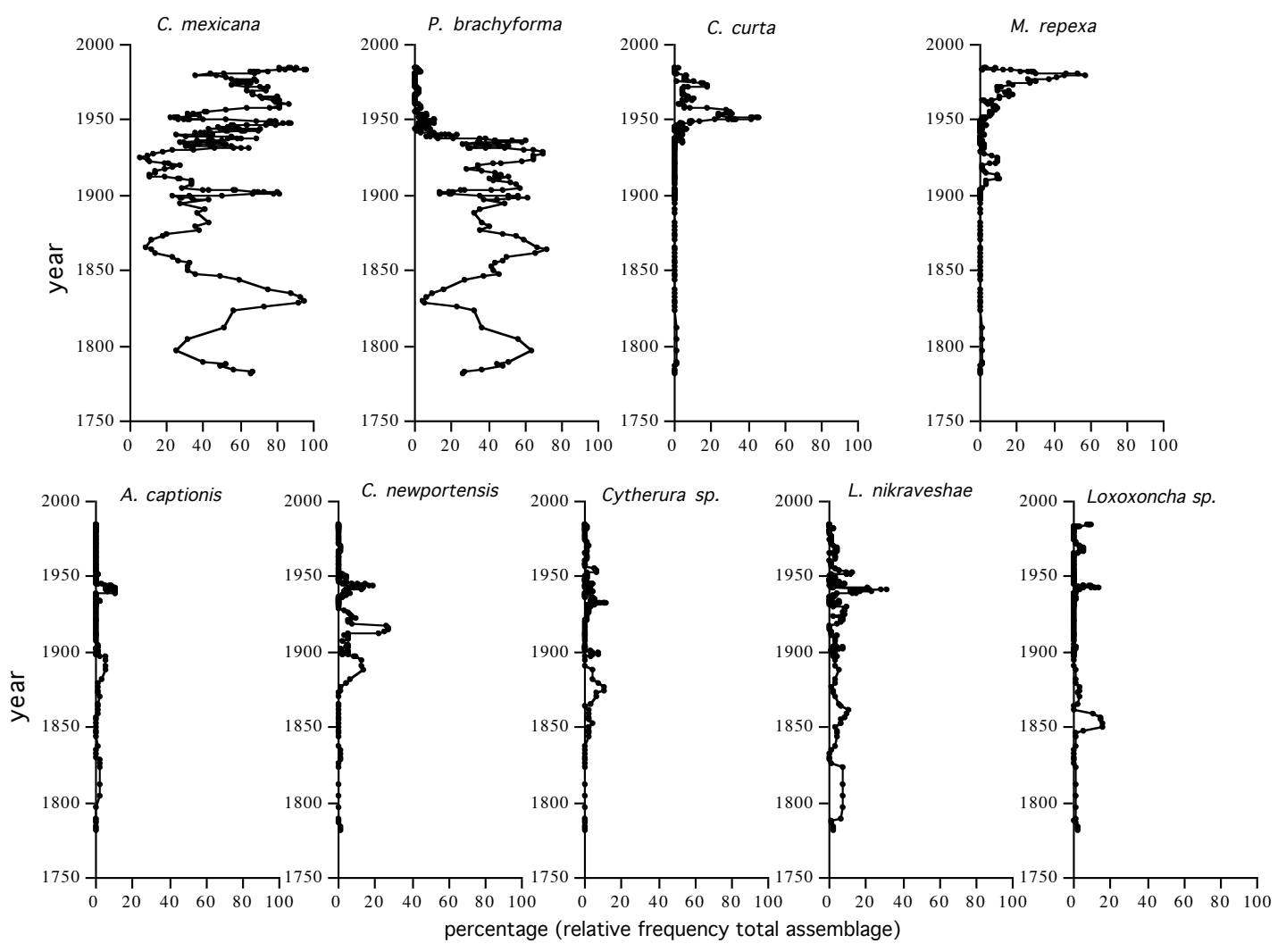

Figure 5.7. High resolution record of ostracodes at site PC-2 since late $18^{\text {th }}$ century. 

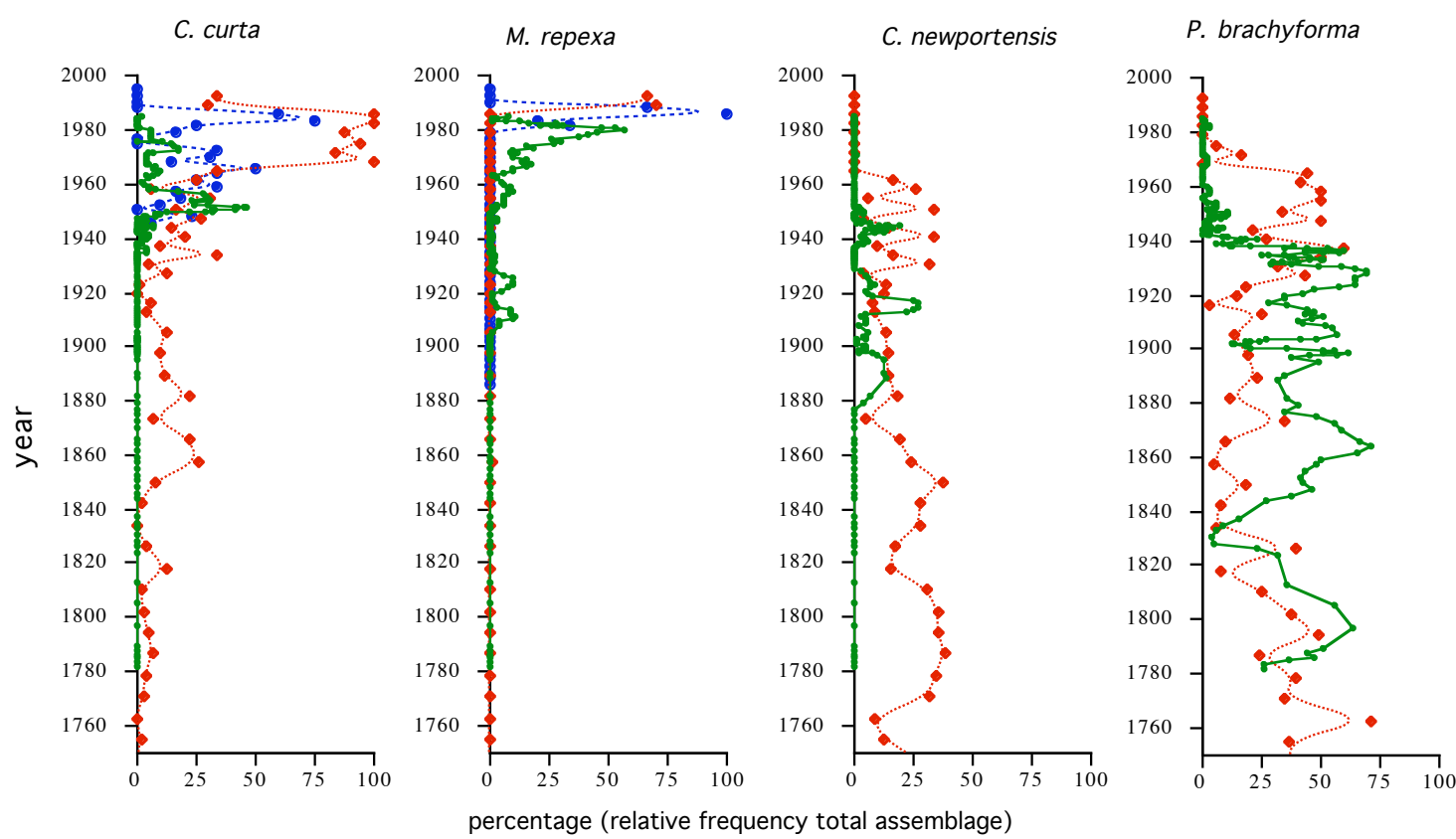

Figure 5.8. Comparison of Pocomoke Sound ostracode trends with those from mainstem Chesapeake Bay off the mouth of Patuxent River from Cronin and Vann (2003). Red = PTXT-2-P-5, Blue = PTXT-2-G, Green $=$ PC-2 cores. 

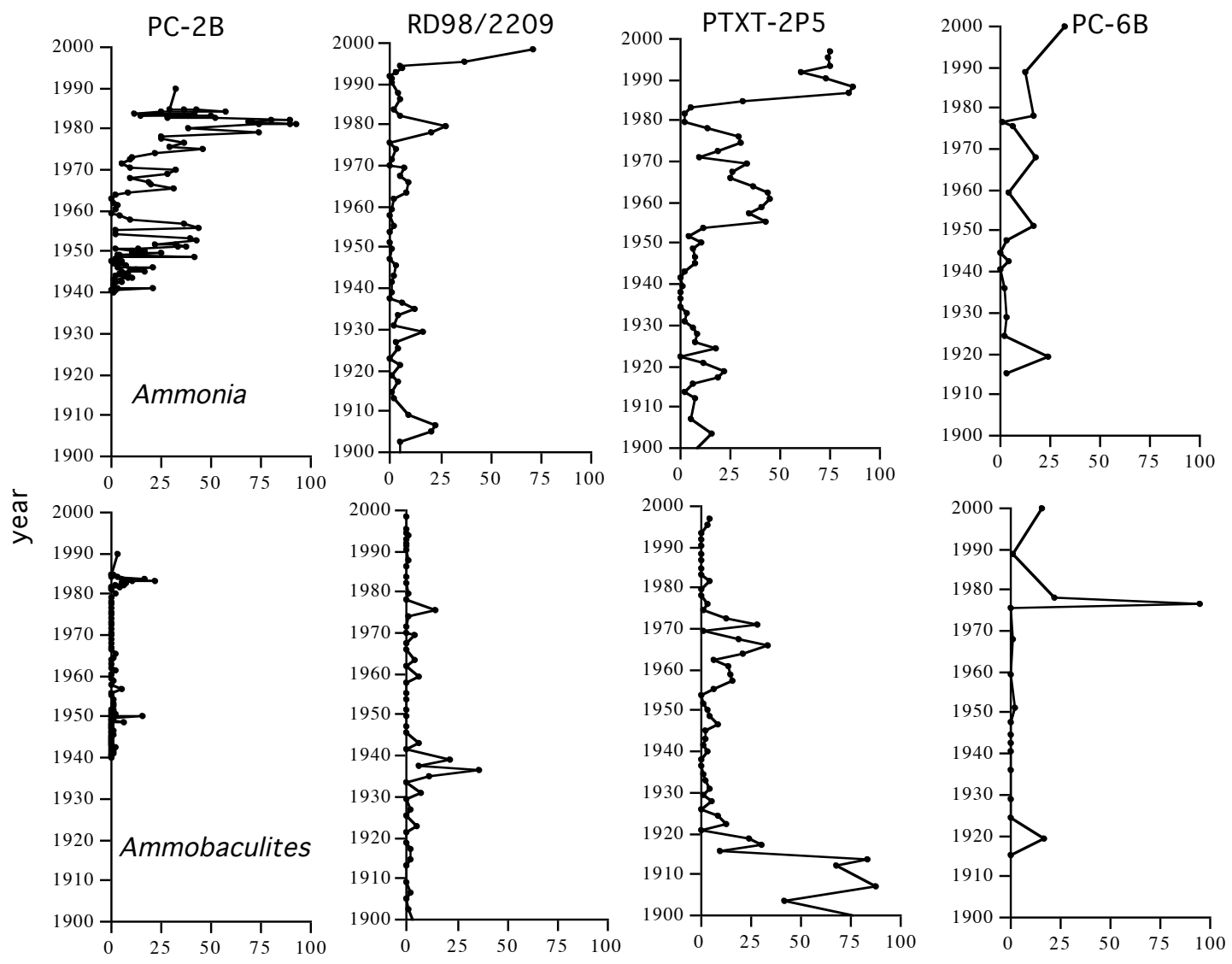

Figure 5.9. Comparison of Pocomoke Sound foraminiferal trends with those found in mainstem Chesapeake Bay. 


\begin{tabular}{|c|c|c|c|c|c|c|c|c|}
\hline CORE & Date & Latitude (N) & Longitude(W) & H2O Depth (m) & Core Depth $(\mathrm{cm})$ & Foraminifera* & Ostracodes* & Stable isotopes ${ }^{* *}$ \\
\hline PC-2-B-1 & $5 / 15$ & 3753.429 & 7548.408 & 7.9 & 200 & $2-\mathrm{cm}$ & $2-\mathrm{cm}$ & NA \\
\hline PC-2-B-3 & $9 / 1$ & $37^{\circ} 53.436$ & $75^{\circ} 48.410$ & 7.9 & 485 & NA & 2 - to $10-\mathrm{cm}$ & $2-\mathrm{cm}$ \\
\hline PC-3-B-1 & $5 / 15$ & 3750.741 & 7548.745 & 11.4 & 177 & $10-\mathrm{cm}$ & $10-\mathrm{cm}$ & NA \\
\hline PC-6-B-1 & $5 / 15$ & 3744.910 & 7552.334 & 14.6 & 169 & $10-\mathrm{cm}$ & $10-\mathrm{cm}$ & NA \\
\hline PC-6-B-2 & $9 / 1$ & $37^{\circ} 44.914$ & $75^{\circ} 52.334$ & 15.3 & 477 & $10-\mathrm{cm}$ & NA & $2-\mathrm{cm}$ \\
\hline
\end{tabular}


Table 2. Ecology and Habitat Preference of Chesapeake Bay

\begin{tabular}{|c|c|c|c|c|c|c|}
\hline $\begin{array}{l}\frac{8}{8} \\
\frac{8}{8}\end{array}$ & 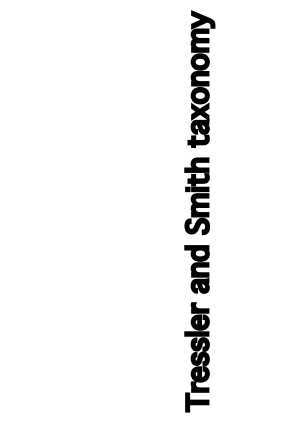 & 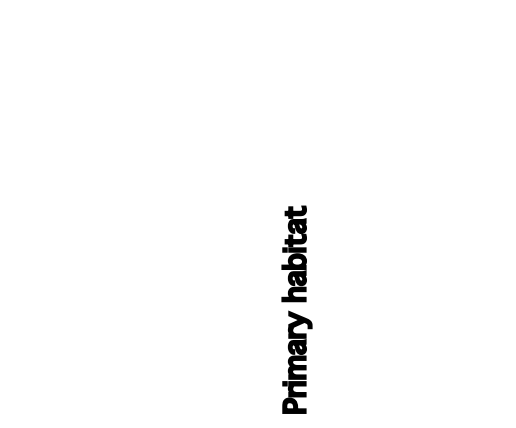 & 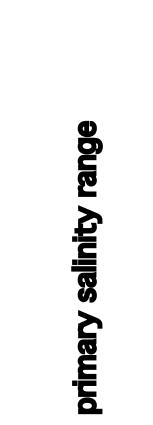 & 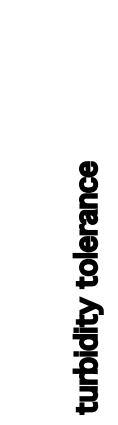 & 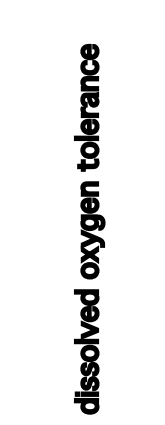 & 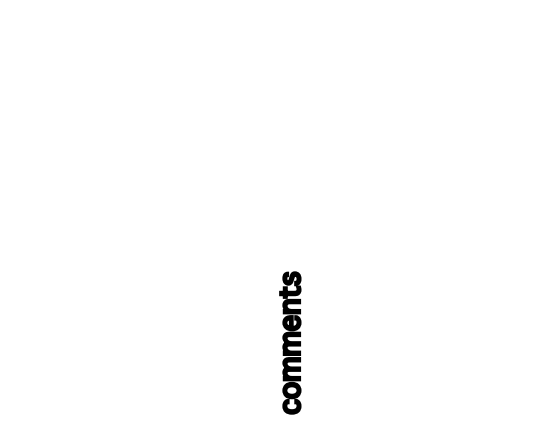 \\
\hline Actinocythereis captionis & not found & muddy, shallow water & 18 to 35 & low & \multicolumn{2}{|c|}{ well oxygenated } \\
\hline Cytheromorpha curta & C. fuscata $* \star \star$ & oligohaline tribs, salt marsh & \multicolumn{2}{|c|}{1 to 30 (usual high } & \multirow{3}{*}{\multicolumn{2}{|c|}{$\begin{array}{l}\text { periodic anoxic opportunistic species when oxygen depletion } \\
? \\
\text { oxygenated }\end{array}$}} \\
\hline Cytheromorpha fuscata & not found $d^{\star \star *}$ & fresh, oligohaline & $<10$ & high & & \\
\hline Cytheromorpha newportensis & & muddy, sandy main channel & & & & \\
\hline Cytherura sp. $B$ & Cytherura gibba & tide pools, inter, subtidal & 15 to 35 & low & oxygenated & \\
\hline Cyprideis mexicana & C. littoralis & Spartina marshes, oyster reefs & 20 to 35 & & oxygenated & \\
\hline Cyprideis spp. & C. beaveni & usually Spartina marsh & 5 to 20 & high & oxygenated & additional taxonomy/ ecology needed \\
\hline Hulingsina rugipustulosa & & sandy shoals, lagoons, bays & 15 to 35 & low & oxygenated & \\
\hline Leptocythere nikraveshae & L. macallana & mudd, organic sediment, inter, subtidal estuaries & & high & hypoxia & \\
\hline Loxoconcha matagordensis** & L. impressa & epiphyte on Zostera marina & 12 to 35 & low & oxygenated & \\
\hline Loxoconcha sp. * & not found & deep channel, sublittoral continental shelf & 20 to 35 & low & oxygenated & dominant in $20-30 \mathrm{ppt}$ in temperate bays, estuaries \\
\hline Perissocytheridea brachyforma & Sarsocythere patuxiensis & bays, lagoons, oyster reefs & 6 to 25 & moderate & oxygenated & detrital feeder \\
\hline Pellucistoma magniventra & no found & continental shelf, euhaline bays, estuaries & $>30$ & low & oxygenated & \\
\hline Pontocythere sp. & Cythere sclerochilus & sandy shoals, lagoons, bays & 12 to 35 & low & oxygenated & \\
\hline Proteoconcha nelsonensis & Hemicythere strandentia & intertidal sandy shoals, salt water lagoons & $15-35$ & low & oxygenated & \\
\hline
\end{tabular}

* referred to as L. granulata by Williams 1966

**L. impressa of Tressler and Smith

${ }^{\star \star \star *}$ The left valve of Cytheromorpha illustrated by Tressler and Smith is clearly C. curta,

however it is possible they also had C. newportensis in their material.

True C. fuscata in the oligohaline of Chesapeake but would not have lived in the salinities at Solomons pier 


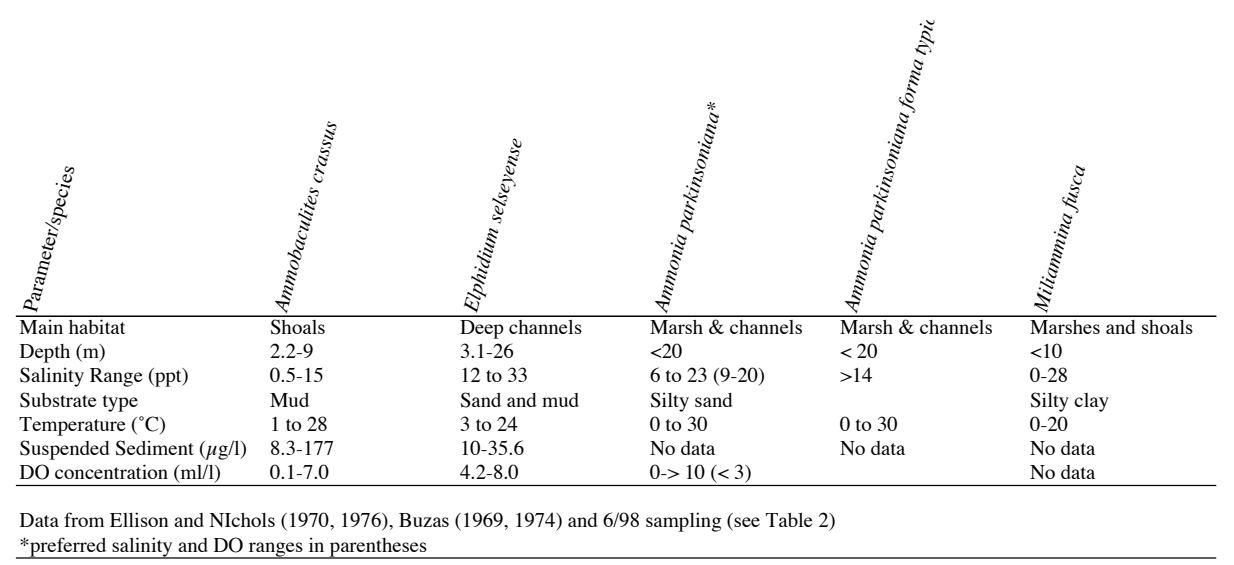




\section{Chapter 6. Stable Isotopes of Foraminifera from Pocomoke Sound}

T. M. Cronin*, R. Thunell**, C. Saenger*, R. R. Seal, II*, C. Vann*

*U.S. Geological Survey Reston, Virginia 20192

** Department of Geological Sciences, University of South Carolina, Columbia, South Carolina 29208

\section{Introduction}

Analysis of the oxygen and carbon isotopic composition of the calcitic $\left(\mathrm{CaCO}_{3}\right)$ shells of foraminifers is a common tool in paleoenvironmental reconstruction because the ratios of heavier $\left({ }^{18} \mathrm{O},{ }^{13} \mathrm{C}\right)$ to lighter $\left({ }^{16} \mathrm{O},{ }^{12} \mathrm{C}\right)$ isotopes are influenced by factors such as the temperature and salinity of the water in which the foraminifer secretes its shell. The oxygen isotopic composition of foraminifer calcite is often expressed as $\square^{18} \mathrm{O}_{\text {foram }}$ in the following relationship:

$$
\square^{18} \mathrm{O}_{\text {foram }}=\frac{\left({ }^{18} \mathrm{O} /{ }^{16} \mathrm{O}\right)_{\text {foram }}-\left({ }^{18} \mathrm{O} /{ }^{16} \mathrm{O}\right)_{\text {standard }}}{\left({ }^{18} \mathrm{O} /{ }^{16} \mathrm{O}\right)_{\text {standard }}} \times 1000
$$

where values are expressed as per mil (0/00). A similar relationship is used to express the $\square^{13} \mathrm{C}_{\text {foram }}$ of foraminiferal calcite. The standards usually used for oxygen and carbon isotopes are Standard Mean Ocean Water (SMOW) and a belemnite from the Cretaceous Pee Dee Formation (PDB) in North Carolina, respectively (see Berger, 1979; Arthur and others, 1983).

Although foraminiferal isotopic ratios are commonly used in deep-sea paleoceanography, this method also holds promise for understanding coastal and estuarine hydrological variability. This chapter describes preliminary results on the oxygen $\left(\square^{18} \mathrm{O}\right)$ and carbon $\left(\square^{13} \mathrm{C}\right)$ composition of the foraminifer Elphidium recovered from sediment cores PC-2B and PC-6B from Pocomoke Sound and compares these records to isotopic curves from the mainstem Chesapeake Bay. 


\section{Material and Methods}

A total of between 5 and 10 specimens of Elphidium were picked at the USGS laboratories in Reston, Virginia, from washed sediment in the $>150-\mu \mathrm{m}$ size fraction at approximately 2-cm spacing from each core (PC-2B, PC-6B). An effort was made to select specimens having the best shell preservation with little of no signs of dissolution. In general, foraminifers are extremely well-preserved in sediments from Pocomoke Sound, showing no visible signs of post-mortem physical or chemical alteration.

The oxygen and carbon stable isotope analyses on foraminifera were carried out at the University of South Carolina using a VG Optima stable isotope ratio mass spectrometer equipped with an Isocarb single acid bath carbonate preparation system which permits automated runs of 40 samples. This system has the capability of analyzing small carbonate samples for isotopic composition ( $<20$ micrograms).

\section{Age Model for Pocomoke Cores}

In order to evaluate the temporal trends in Pocomoke isotopes and establish correlations to cores in other parts of the bay, we constructed age model for Pocomoke cores PC-2B-3 and PC-6B-2 using a combination of age data from several sources. These include patterns in anthropogenic lead and Cesium-137 $\left({ }^{137} \mathrm{Cs}\right)$ from core PC-6B-2 (Holmes and Marot, Chapter 2, this volume), the peak in ragweed (Ambrosia) pollen from several Pocomoke Sound cores (Willard and Bernhardt, Chapter 7, this volume), and radiocarbon dates from Pocomoke cores (Cronin and others, Chapter 4, this volume). Together with the lead, radio-isotopic and pollen data, we also used foraminiferal oxygen isotopic data as a means of correlating cores based on downcore isotopic excursions observed in all the cores (see below).

\section{Foraminiferal Isotopic Results}


Figure 6.1 shows the $\square^{18} \mathrm{O}_{\text {foram }}$ and carbon $\square^{13} \mathrm{C}_{\text {foram }}$ for the two cores plotted against the age model discussed below; the isotopic data are summarized in Table 6.1. The mean $\square^{18} \mathrm{O}_{\text {foram }}$ values for all samples from PC-2B and PC-6B were $-1.610 / 00$ and

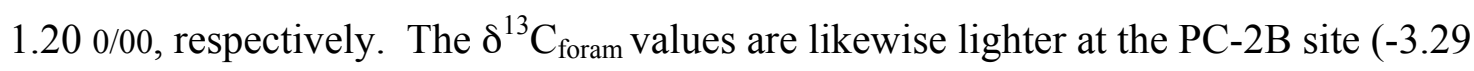
$0 / 00$ versus $-3.000 / 00$ at $\mathrm{PC}-6 \mathrm{~B})$. These patterns show that mean isotopic values are lighter (more negative) at core sites located closer to the source of fresh water and probably reflect the influence of isotopically light oxygen in water nearer to shore and river mouths and terrestrially derived organic material (see next section).

We also computed the mean $\square^{18} \mathrm{O}_{\text {foram }}$ and $\square^{13} \mathrm{C}_{\text {foram }}$ values for the pre- and post1900 intervals in order to see if any long-term change had occurred (Table 6.1). Preand post-1900 $\square^{18} \mathrm{O}_{\text {foram }}$ and $\square^{13} \mathrm{C}_{\text {foram }}$ for core PC-2B show no appreciable change during the last 100 years. In core $\mathrm{PC}-6 \mathrm{~B}$, post- $1900 \square^{18} \mathrm{O}_{\text {foram }}$ values are about $0.170 / 00$ heavier than values prior to 1900 , whereas $\square^{13} \mathrm{C}_{\text {foram }}$ values are on average about $0.30 / 00$ lighter since 1900 .

Figure 6.1 also shows significant decadal variability in both $\square^{18} \mathrm{O}_{\text {foram }}$ and carbon $\square^{13} \mathrm{C}_{\text {foram }}$ at both core sites. $\square^{18} \mathrm{O}_{\text {foram }}$ values prior to $\sim 1900 \mathrm{AD}$ have about a $20 / 00$ range of variability; after $1900, \square^{18} \mathrm{O}_{\text {foram }}$ values exhibit greater negative and positive excursions, which are more obvious in core PC-2B. Similarly, the $\square^{13} \mathrm{C}_{\text {foram }}$ values similarly have about a $20 / 00$ range at PC-2B prior to $1900 \mathrm{AD}$ and about $1.50 / 00$ at PC$6 \mathrm{~B}$, and the range of variability increases markedly after $1900 \mathrm{AD}$, especially in PC-2B.

The most obvious isotopic "events" are the positive excursions in both cores and in both oxygen and carbon isotopes just prior to 1800 , around 1900, and during the late 1950s and early 1960s. The sharp negative excursion around 1950 in foraminiferal $\square^{18} \mathrm{O}$ and $\square^{13} \mathrm{C}$ is also one of the more striking aspects of the isotopic record.

\section{Factors influencing Foraminiferal Isotopic Composition}

\section{Oxygen isotopes}

The first factor to consider when interpreting isotopic composition of foraminiferal shells is whether the particular foraminiferal species or genus secretes its shell in isotopic equilibrium with the surrounding seawater. This complication has been 
referred to as the "vital effect" and it requires researchers to calibrate isotopic records from two different foraminiferal genera when more than one foraminiferal genus is analyzed in a core. Such a situation exists in studies of deep-sea planktonic and benthic foraminifers.

Surprisingly, relatively little exist on oxygen isotopic vital effects in shallow water estuarine foraminiferal species. Nonetheless, Grossman $(1984,1987)$ conducted a survey of isotopes in many benthic foraminiferal genera and data for Elphidium suggest that the isotopic composition of its shell is out of equilibrium with the seawater in which it grows by about 0.8 per mil for $\square^{18} \mathrm{O}$. Thomas and others (2000) also conducted a preliminary study of isotopes of Elphidium excavatum from Long island Sound at salinities similar to those of Pocomoke Sound (20-30 ppt) and found an offset of about $1.10 / 00$. They pointed out the vital effect is not critical in cases where the same species are being analyzed in a study, such as the current one.

Assuming there is no temporal variability in the vital effect for the species of Elphidium living in Chesapeake Bay, their oxygen isotopic composition should be influenced primarily by the salinity and the temperature of the water in which they secrete their shell. Epstein and others (1953) determined the relationship between $\square^{18} \mathrm{O}$ of carbonate and temperature expressed in the following equation:

$$
\mathrm{T}=16.9-4.2\left(\square_{\text {arbonate }}-\square_{\text {water }}\right)+0.13\left(\square_{\text {carbonate }}-\square_{\text {water }}\right)^{2}
$$

where $\mathrm{T}$ is temperature $\left({ }^{\circ} \mathrm{C}\right)$, $\square$ carbonate is the per mil difference between carbonate and standard mean ocean water (SMOW), $\square_{\text {water }}$ is the difference between $\square^{18} \mathrm{O}_{\text {water }}$ and that of SMOW. In general, other factors being equal, a one per mil change in $\square^{18} \mathrm{O}_{\text {foram }}$ is equivalent to a temperature change of about $4^{\circ} \mathrm{C}$.

In addition to temperature, the isotopic composition of estuarine waters is also influenced by the mixing of isotopically heavy marine water with isotopically light freshwater from regional precipiation and freshwater discharge. Thus, there should be a strong relationship between estuarine salinity and $\square^{18} \mathrm{O}_{\text {water. }}$. We obtained $\square^{18} \mathrm{O}_{\text {water }}$ values from a transect of water samples taken along the salinity gradient in the Potomac River and the polyhaline region of Chespapeake Bay in order to examine the modern $\square^{18} \mathrm{O}_{\text {water }}$ 
gradient (Figure 6.2; http://geology.er.usgs.gov/eespteam/atlantic/index.htm.). We included in Figure $6.2 \square^{18} \mathrm{O}_{\text {water }}$ values from oceanic water from the adjacent Atlantic continental shelf obtained from Chapman and others (1986, also Chapman and Beardsley, 1989) and Khim and Krantz (1996).

This plot demonstrates the following salinity $-\square^{18} \mathrm{O}_{\text {water }}$ relationship:

$$
\square^{18} \mathrm{O}_{\text {water }}=0.189 \mathrm{x} \text { (salinity) }-6.619\left(\mathrm{r}^{2}=0.96\right)
$$

Lower mesohaline waters have $\square^{18} \mathrm{O}_{\text {water }}$ values around -6 to $-50 / 00$, polyhaline waters near $-30 / 00$ and marine waters $-10 / 00$. Ingram and others (1996) found a generally similar $\square^{18} \mathrm{O}_{\text {water }}$ gradient in San Francisco Bay. The few fresh water samples shown in Figure 6.2 exhibit a wide range of $\square^{18} \mathrm{O}$ values as would be expected from the influence of short-term temporal and spatial variability in precipitation sources throughout the watershed region.

An additional factor to consider when interpreting foraminiferal oxygen isotopes is the fact that the growth of continental ice sheets during glacial periods causes large quantities of isotopically light fresh water to be stored on land as ice (as much as $120 \mathrm{~m}$ of sea-level equivalent). Glacial-interglacial ice-volume cycles occur over tens to hundreds of thousands of years and thus the ice volume effect is not a factor over the decadal to centennial timescales of the current study.

\section{Carbon isotopes}

Carbon isotopic ratios in estuarine water and sediments are influenced by the source of the organic carbon, which is influenced largely from the mixing of lighter ( $260 / 00)$ terrestrially-derived organic matter and heavier $(\sim 200 / 00)$ marine organic matter. These carbon sources influence the composition of the dissolved inorganic carbon (DIC) taken up by foraminifera during shell growth such that there is an idealized salinity- $-\square^{13} \mathrm{C}$ gradient across the 0 to $350 / 00$ salinity range. However, as shown by Thomas and others (2000) for Long Island Sound, other geochemical processes operating within the estuary can also influence the carbon isotopic composition of the DIC available to foraminifera for shell secretion. The two most important processes are primary productivity, which 
leads to heavier isotopic values when productivity is high, and oxidation of organic matter in the water column or near the bay bottom, which leads to lighter values (Anderson et al., 1983; Thomas and others, 2000). These processes, especially oxidation in the deep channel of Chesapeake Bay where seasonal hypoxia has occurred for at least a century (Zimmerman and Canuel, 2000; Cronin and Vann, 2003), might

account for temporal patterns in $\square^{13} \mathrm{C}_{\text {foram }}$ that do not seem to be controlled by salinity (see below).

Carbon derived from different types of terrestrial plant can also be a source of variability; $\mathrm{C}_{3}$ plants (trees shrubs) usually have lighter and $\mathrm{C}_{4}$ plants (agricultural plants and grasses) have heavier organic carbon isotopic values. Similarly, marsh plants and submerged aquatic grasses living along the margins of Chesapeake Bay have relatively heavy carbon isotopic values. However, Bratton and others (2003) concluded from a study of carbon isotopes in Chesapeake Bay sediments that neither terrestrial plant type nor coastal marsh and seagrass sources had an appreciable influence on $\square^{13} \mathrm{C}$ trends obtained from fine-grained sediments deposited in deeper regions of Chesapeake Bay where our cores were taken and Elphidium lives. Elphidium is also known to have photosynthetic endosymbionts living in its shell, but it is not clear if these influence these influence the Chesapeake foraminiferal carbon isotope composition.

Two other factors can influence the $\square^{13} \mathrm{C}$ values on benthic foraminifers - vital effects and microhabitat effects. Vital effects in $\square^{13} \mathrm{C}_{\text {foram }}$ are caused by either metabolic processes (i.e., algal or bacterial symbionts living in the foraminifera, Romanek and others, 1992) or kinetic processes (related to how fast the organism secretes its shell). Microhabitat effects involve differences in the isotopic composition of DIC in bottom water versus sediment pore water. Chandler and others (1996) found a strong microhabitat effect in experimentally cultured Ammonia from the Gulf of Mexico such that the $\square^{13} \mathrm{C}_{\text {foram }}$ for shells secreted their shell in these living epifaunally (in bottom water) versus infaunally (in pore water) the influence of variability in $\square^{13} \mathrm{C}$.

\section{Paleosalinity during the last few centuries in Chesapeake Bay}


Comparison of the $\square^{18} \mathrm{O}_{\text {foram }}$ and $\square^{13} \mathrm{C}_{\text {foram }}$ records from the two PC-cores and the $\mathrm{RD} / 2209$ core from the north-central bay provide evidence that, over the past few centuries, variability in both isotopes is primarily controlled by salinity and the mixing of freshwater and marine endmembers. Figures 6.3 and 6.4 show the Pocomoke oxygen and carbon isotopic records compared with those from the mainstem bay at sties $\mathrm{RD} / 2209$ and PTXT-2. Both oxygen and carbon isotope records exhibit correlative decadal-scale trends at the three sites suggesting that salinity was a primary, though not necessarily the only factor, influencing the foraminiferal isotopic composition at these timescales.

We also used the oxygen isotopic records to "retrodictively" estimate paleosalinity following the procedures of Saenger and others (in press). In brief, this approach computes $\square^{18} \mathrm{O}_{\text {water }}$ from the $\square^{18} \mathrm{O}_{\text {foram }}$ based on the equation in Figure 6.2, and uses statistical models relating bay salinity to Susquehanna River discharge, and discharge to regional precipitation, to calculate paleosalinity trends. Water temperature effect on $\square^{18} \mathrm{O}_{\text {foram }}$ is factored out by independently measuring paleotemperature of the water in paired samples using magnesium/calcium ratios in fossil ostracodes (Cronin and others, 2003).

Figure 6.4 shows the resulting salinity patterns for the past 500 years and the anchor points used to develop the age model for cores RD/2209, PC-2B and PC-6B. It should be emphasized that because ${ }^{137} \mathrm{Cs}$ and lead data were not available for all cores, and in some cases geochronological dating was carried out on a dedicated core, we used the $\square^{18} \mathrm{O}_{\text {foram }}$ curve to "tune" the correlations among the three cores. For example, the stratigraphic position of the lead peak coincides with an isotopically heavy (high salinity) period near 1975 in both RD/2209 and PC-6B. Similarly, the ${ }^{137}$ Cs peak lies stratigraphically below the lead peak in both cores in an interval yielding slightly lower oxygen isotopic values. The third anchor point is the peak in ragweed pollen around 1880-1890 during a negative $\square^{18} \mathrm{O}$ excursion. Despite age uncertainty, the records from the three cores are generally similar in the decadal patterns of salinity. Mean long-term salinity at PC-6B, the most saline of the three sites today, is higher than that at site PC$2 \mathrm{~B}$, which in turn is higher than that at site $\mathrm{RD} / 2209$. Periods of relatively high salinity corresponding to low freshwater discharge are evident near the turn of the $20^{\text {th }}$ century, between 1910 and 1930, during the 1940s, and during the 1960s. Following relatively 
low salinity during the 1970 s and 80 's, there is evidence for increased salinity during the late 1980s and early 1990s at sites PC-2B and RD/2209 (the uppermost sediments at site PC-6B were disturbed).

\section{Conclusions}

These data allow us to postulate that stable isotope stratigraphy from Chesapeake Bay foraminifera, particularly oxygen isotope records, can be used as a means of correlation of sediment cores within the bay. Moreover, if regional decadal and centennial climate processes influence salinity as we suspect (Cronin and others, 2000, 2003), then it might be possible to extend this concept of isotope stratigraphy to other bays and estuaries because historical large-scale droughts and wet periods are known to have influenced large regions of the eastern United States. Large-scale regional climate variability should in theory have led to similar salinity variability in coastal environments influenced by freshwater river runoff and be manifested in the isotopic record of foraminifers. Future work is planned to further refine our understanding of the salinity signal from foraminferal isotopes with particular emphasis on identifying the long term climatic controls on oxygen isotopes and salinity and decoupling the effects of other processes (productivity and oxidation) on dissolved inorganic carbon and foraminferal carbon isotopes.

\section{References}

Anderson, T. F., and Arthur, M. A., 1983, Stable isotopes of oxygen and carbon and their application to sedimentologic and paleoenvironmental problems, In:, Arthur, M. A., Anderson, T. F., Kaplan, I. R., Veizer, J., and Land, L. S., (eds.), Stable Isotopes in Sedimentary Geology, Society of Economic Paleontologists and Mineralogists Short Course 10, p. 1-151.

Berger, W., 1979, Cushman Foundation Short Course on Foraminifera, pp. 156-198. 
Bratton, J. F., Colman, S. M., and Seal, R. R. II, 2003, Eutrophication and carbon sources in Chesapeake Bay over the last 2700 years: Human impacts in context: Geochimica et Cosmochimica Acta, v. 67, No. 18, p. 3385-3402.

Chandler, G. T., Williams, D. F., Spero, H. J., and Xiaodong, G., 1996, Sediment microhabitat effects on carbon stable isotopic signatures of microcosm-cultured benthic foraminifera: Limnology and Oceanography, v. 41, p. 680-688.

Chapman, D. C., Barth, R. C., Beardsley, R. C., and Fairbanks, R. G., 1986, On the continuity of mean flow between the Scotian Shelf and the Middle Atlantic Bight: Journal of Physical oceanography, v. 16, p. 758-772.

Chapman, D. C. and Beardsley, R. C., 1989, on the origin of shelf water in the Middle Atlantic Bight: Bulletin American Meteorological Society, v. 19, p. 384-391.

Cronin, T., Willard, D., Karlsen, A., Ishman, S., Verardo, S., McGeehin, J., Kerhin, R., Holmes, C., Colman, S., Zimmerman, A., 2000. Climatic variability in the eastern United States over the past millennium from Chesapeake Bay sediments. Geology. vol. 28, p. 3-6.

Cronin, T. M., Dwyer, G. S., Kamiya, T., Schwede, S., Willard, D. A., 2003. Medieval Warm Period, Little Ice Age and $20^{\text {th }}$ century temperature variability from Chesapeake Bay. Global and Planetary Change. vol 36, p. 17-29.

Cronin, T. M., Robertson, M., Willard, D. A., and Halka, J. Stratigraphy and Age of Pocomoke Sound Sediments: U.S. Geological Survey Open-file Report. This volume.

Cronin, T. M. and Vann, C., 2003, The sedimentary record of anthropogenic and climatic influence on the Patuxent Estuary and Chesapeake Bay ecosystems: Estuaries, v. 26, no. 2a, p. 196-209.

Epstein, S., Buchsbaum, R., Lowenstam, H., and Urey, H. 1953. Revised carbonate-water isotopic temperature scale: Geological Society of America, Bulletin, v. 64, p. 1315-1326.

Grossman, E. L., 1984, Stable isotope fractionation in live benthic foraminifera from the southern California borderland: palaeogeography, palaeoclimatology, Palaeoecology, v. 47, p. 301-327. 
Grossman, E. L. 1987. Stable isotopes in modern benthic foraminifera: a study of vital effect. Journal of Foraminiferal Research, v. 17 (1), p. 48-61.

Holmes, C. and Marot, M., Sediment and chemical flux history in the Pocomoke Sound as defined by short lived isotopic analyses: U.S. Geological Survey Open-file Report. this volume.

Ingram, B. L., Conrad, M. E., and Ingle, J. C., 1996, Stable isotope and salinity systematics in estuarine waters and carbonates: San Francisco Bay: Geochimica et Cosmochimica Acta, v. 60, p. 455-467.

Khim, B.-K., and Krantz, D. E., 1996, Oxygen isotopic identity of the Delaware Coastal Current: Journal of Geophysical Research, v. 101, No. C7, p. 16,509-16,514.

Romanek, C. S., Grossman, E. L., and Morse, J. W., 1992, Carbon isotopic fractionation in synthetic aragonite and calcite: Effects of temperature and precipitation rate: Geochimical et Cosmochimica Acta, v. 56, p. 419-430.

Saenger, C., Cronin, T. M., Thunell, R., and Vann' C. in press, Modeling River Discharge, Precipitation, and Estuary Salinity: Application to Holocene Paleoclimate History: The Holocene.

Shackleton, N. J. and Opdyke, N. D. 1973. Oxygen isotope and paleomagnetic stratigraphy of equatorial Pacific core V28-238: Oxygen isotope temperature and ice volumes on a 105 and 106 year scale: Quaternary Research, v. 3, p. 39-55.

Thomas, E., Gapotchenko, T., Varekamp, J. C., Mecray, E. L., and Buchholtz ten Brink, M. R., 2000, Benthic foraminifera and environmental changes in Long Island Sound: Journal of Coastal Research v. 16, p. 641-655.

Willard, D. A., and Bernhardt, C., Pollen Stratigraphy and Land-Use Change, Pocomoke Sound, Maryland: U.S. Geological Survey Open-file Report. This volume.

Zimmerman, A. R., and Canuel, E. A., 2000, A geochemical record of eutrophication and anoxia in Chesapeake Bay sediments: anthropogenic influence on organic matter composition: Marine Chemistry, v. 69, p. 117-137. 

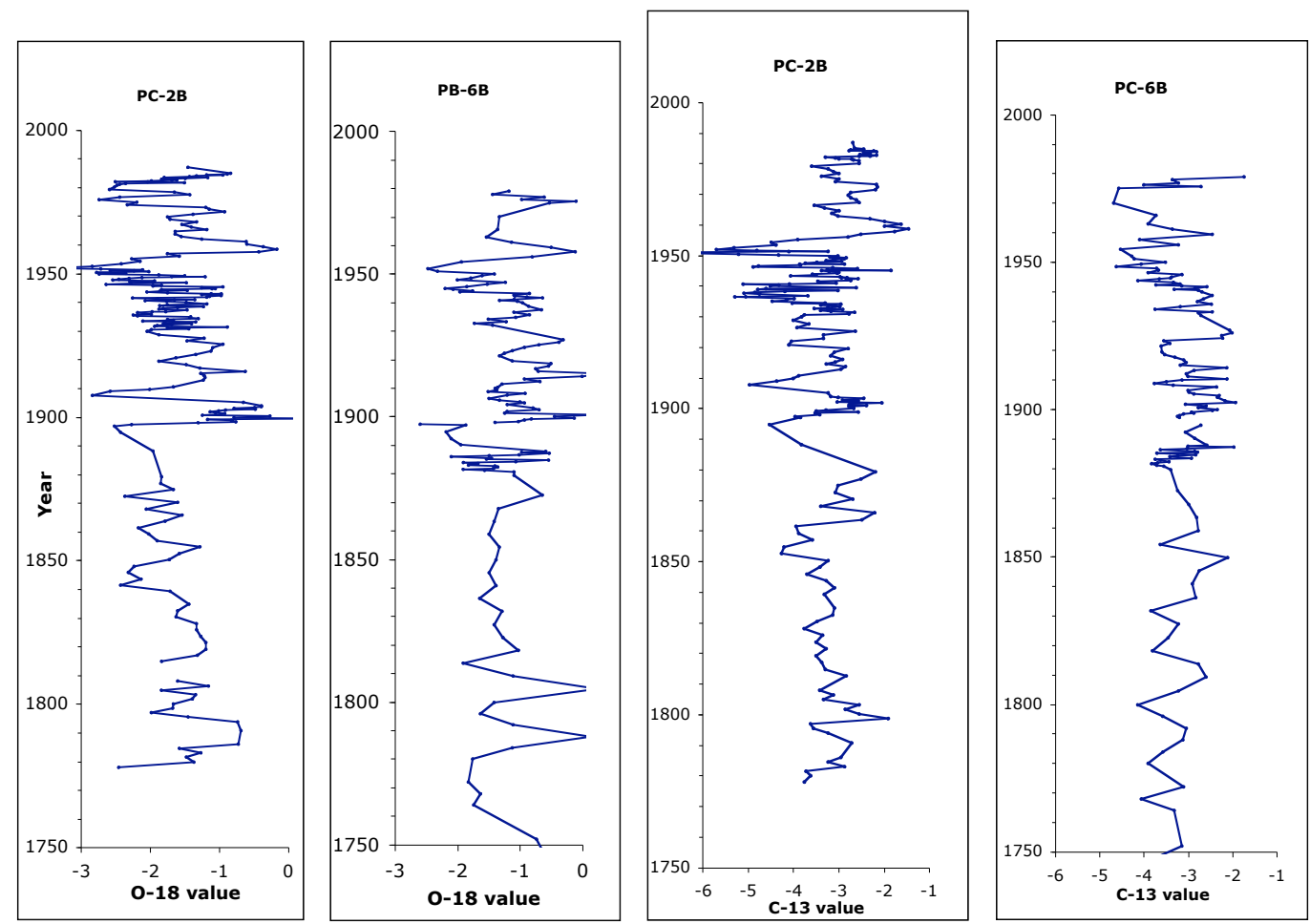

Figure 6.1. Plot showing oxygen and carbon isotopic values of the foraminifera Elphidium from Pocomoke cores PC-2B and PC-6B. 


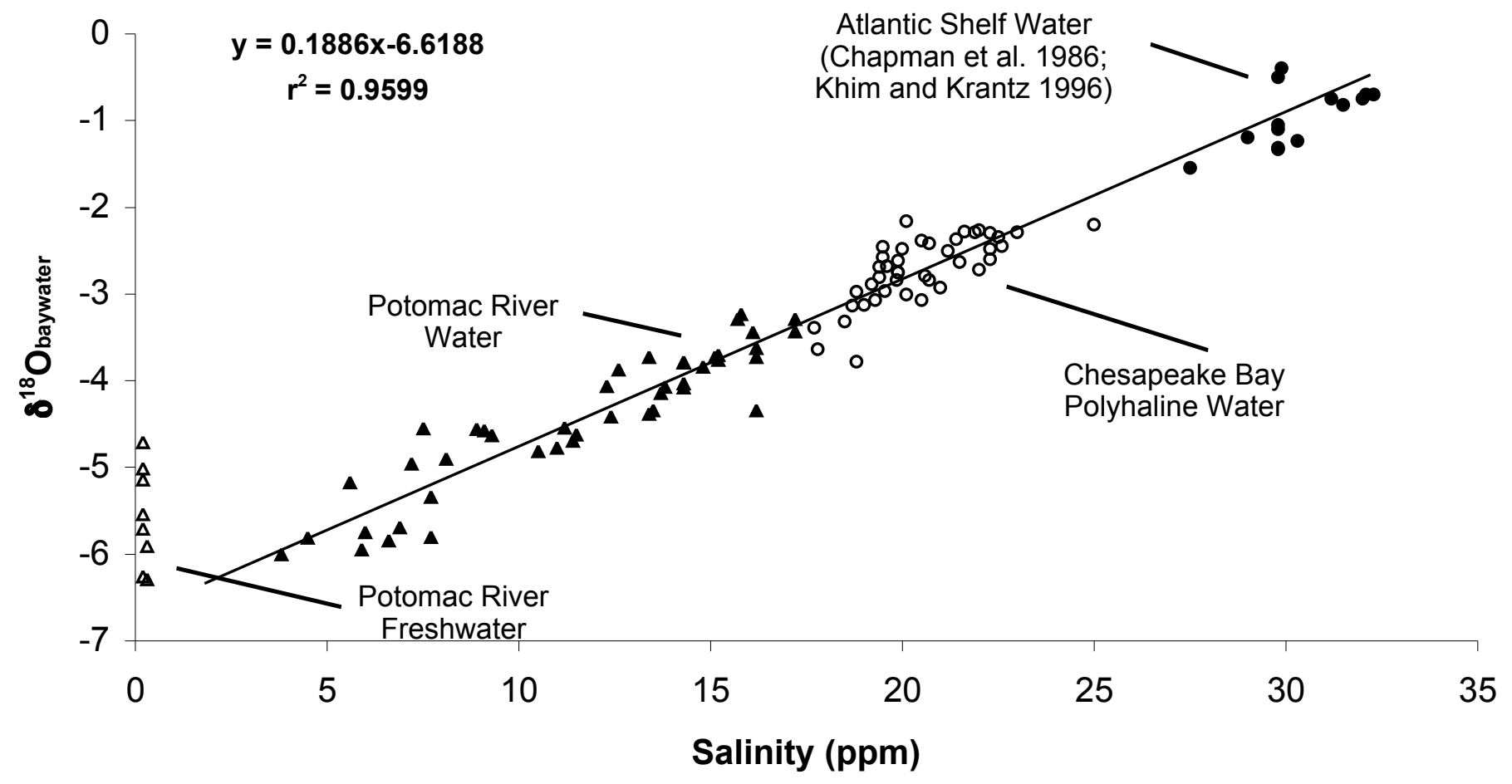

Figure 6.2. Relationship between salinity and oxygen isotope ratios of water in Chesapeake Bay, the Potomac River and the adjacent continental shelf. 
Oxygen Isotope Stratigraphy, Chesapeake Bay

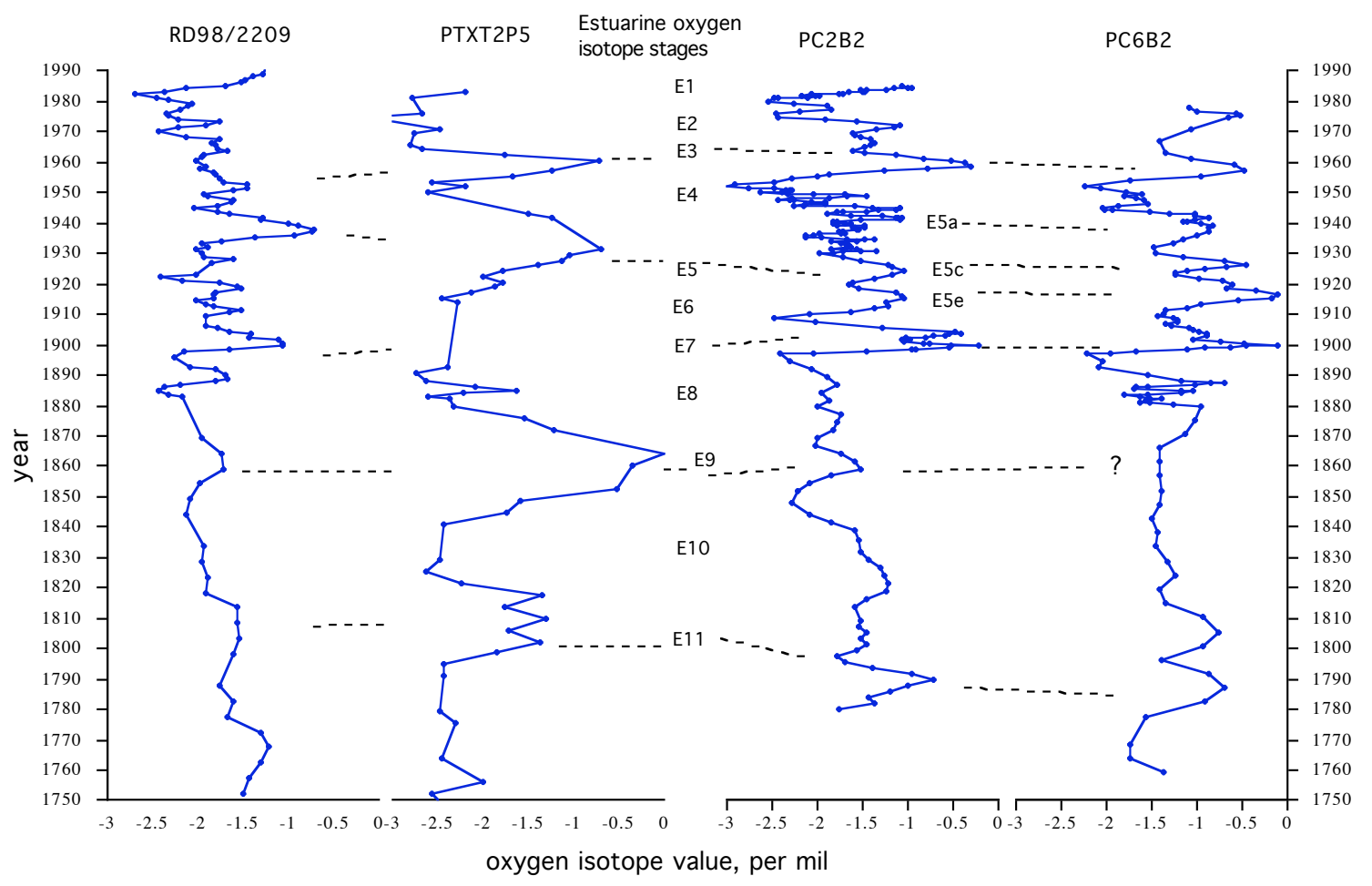

Figure 6.3. Plot showing oxygen isotope stratigraphy of cores from Pocomoke Sound and Chesapeake Bay. 

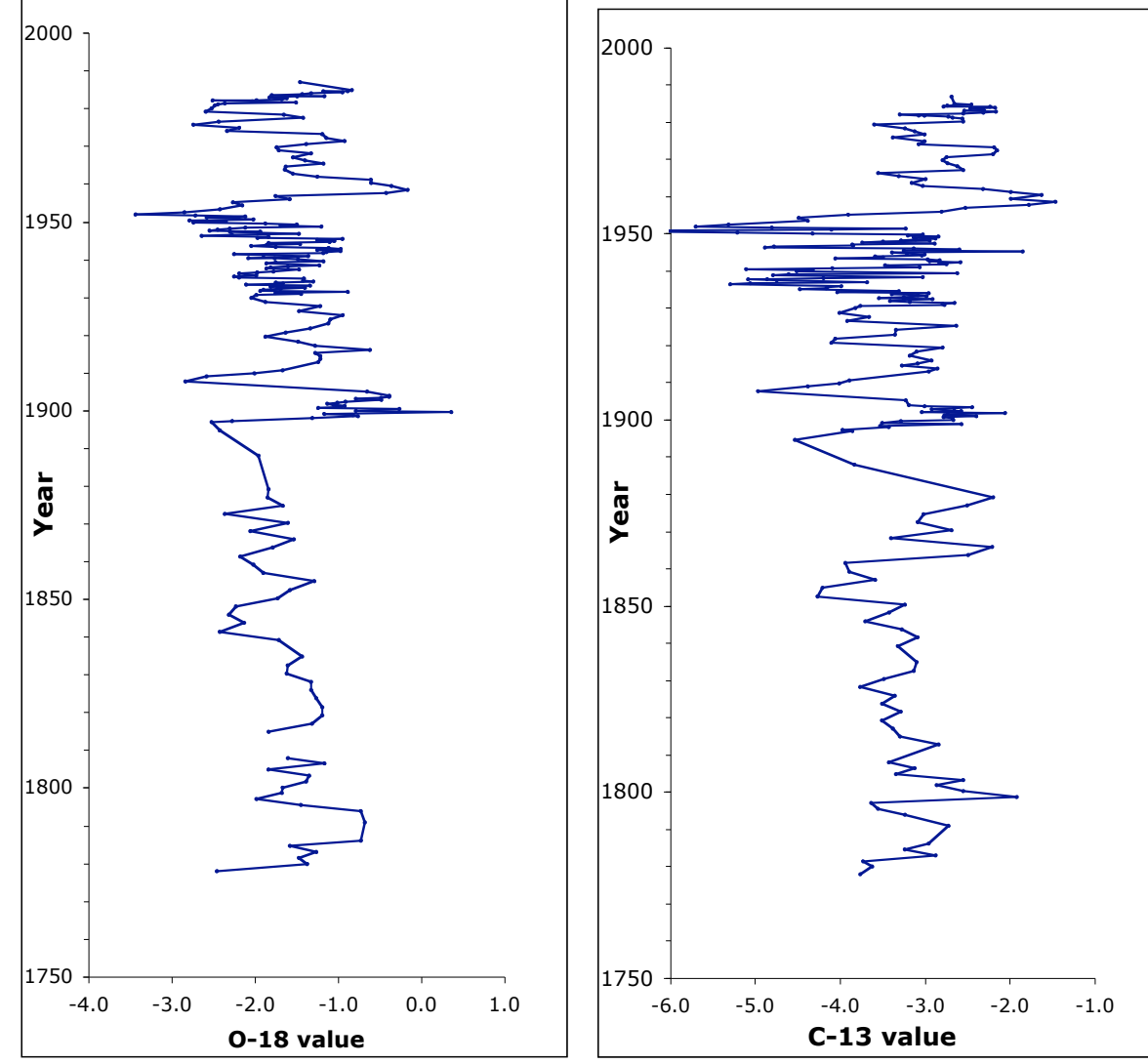

Figure 6.4. Plot of carbon isotopic values of Elphidium since 1750 AD. 
Table 6.1 Summary of Foraminiferal Isotope Data

\begin{tabular}{|cccc|}
\hline & & ${ }^{18} \mathrm{O}$ & ${ }^{13} \mathrm{C}$ \\
\hline PC-2B & $1750-1995$ & -1.611658 & -3.294679 \\
& $1750-1900$ & -1.596255 & -3.284223 \\
& post-1900 & -1.61673 & -3.298185 \\
PC-6B & & & \\
& $1750-1995$ & -1.20088 & -3.000787 \\
& $1750-1900$ & -1.276715 & -2.873842 \\
& post-1900 & -1.109687 & -3.153441 \\
RD/2209 & & & \\
& 2200 yrBP-present & -1.077172 & -3.300242 \\
& $1750-1900$ & -1.736699 & -4.333757 \\
& post-1900 & -1.812694 & -3.81352 \\
\hline
\end{tabular}

values given in per mil (0/00) 


\title{
Chapter 7. Pollen Stratigraphy and Land-Use Change, Pocomoke Sound, Maryland
}

\author{
D. A. Willard*, C. E. Bernhardt*
}

*U.S. Geological Survey, Reston, Virginia 20192

\section{Introduction}

The pollen record of land-use change in Chesapeake Bay is generally well-understood for the northern and central parts of Chesapeake Bay, showing increases in abundance of weedy species such as Ambrosia (ragweed) and Poaceae (grasses) occurring during times of maximum land clearance and preferential loss of hardwoods due to logging (Brush, 1984; Willard and others, 2003). Because Ambrosia aggressively colonizes cleared land within the first year of clearance (Bazzaz, 1974) and produces large quantities of pollen, it is an excellent biostratigraphic marker in eastern North American sediments and has recently been put to use in establishing post-Colonial sedimentation rates in estuarine and terrestrial sediments (Cronin and others, 2003; Townsend and others, 2002). The composition of pollen assemblages also provides information on sediment source. Earlier work in the Potomac River estuary (Defries, 1981) correlated abundance of Chenopodiaceae pollen with proximity to shore, and our current work in Pocomoke surface sediments showed similar patterns (Willard and others, Chapter 3, this volume). Here, we present results from a series of nine cores collected in Pocomoke Sound (Figure 7.1) summarizing both sedimentation patterns in the Sound and land-use patterns interpreted from pollen records.

\section{Material and Methods}


Pollen was analyzed from nine cores collected in Pocomoke Sound on the R/V Kerhin in September, 2001 (Figure 7.1: PC-2B, PC-2B-3: $37^{\circ}$ 53.429’N, 75²448.408’W, 7.9 mwd; PC3B: $37^{\circ} 50.741^{\prime} \mathrm{N} 75^{\circ} 48.745^{\prime} \mathrm{W}, 11.4 \mathrm{mwd}$; PC-4B: $37^{\circ} 8.300^{\prime} \mathrm{N}, 75^{\circ} 50.301^{\prime} \mathrm{W}, 27.3 \mathrm{mwd}$; PC-4C: $37^{\circ} 48.496^{\prime} \mathrm{N}, 75^{\circ} 49.820^{\prime} \mathrm{W}, 7.3$ mwd; PC-6B: $37^{\circ} 44.910^{\prime} \mathrm{N}, 7^{\circ} 52.334^{\prime} \mathrm{W} ; 114.6$ mwd; TR-1D: $37^{\circ} 56.300^{\prime} \mathrm{N}, 75^{\circ} 39.110^{\prime} \mathrm{W}$; $1.5 \mathrm{mwd}$; TR-2D: $37^{\circ} 56.473^{\prime} \mathrm{N}, 75^{\circ} 40.257^{\prime} \mathrm{W}, 1.6$ mwd; TR-5: $37^{\circ} 57.086^{\prime} \mathrm{N}, 76^{\circ} 38.880^{\prime} \mathrm{W}, 1.9 \mathrm{mwd}$ ). Cores PC-6B and PC-2B-3 were collected using a piston corer; the other cores were collected with a gravity corer. Cores were $\mathrm{x}$ radiographed at the Maryland Geological Survey and described at the U.S. Geological Survey. Samples were collected as two-centimeter increments every ten centimeters within the core for palynological analysis.

Pollen was isolated from sediments using standard palynological preparation techniques (Traverse, 1988; Willard and others, 2003). After drying the sediment, one tablet of Lycopodium spores was added to each sample. Samples were processed with $\mathrm{HCl}$ and $\mathrm{HF}$ to remove carbonates and silicates respectively, acetolyzed (1 part sulfuric acid: 9 parts acetic anhydride) in a boiling water bath for 10 minutes, neutralized, and treated with $10 \% \mathrm{KOH}$ for 10 minutes in a water bath at $70^{\circ} \mathrm{C}$. After neutralization, residues were sieved with $149 \mu \mathrm{m}$ and $10 \mu \mathrm{m}$ nylon mesh to remove the coarse and clay fractions, respectively. When necessary, samples were swirled in a watch glass to remove mineral matter. After staining with Bismarck Brown, palynomorph residues were mounted on microscope slides in glycerin jelly. At least 300 pollen grains were counted from each sample to determine percent abundance and concentration of palynomorphs. Pollen data are available online at http://geology.er.usgs.gov/eespteam/atlantic/index.htm or from the North American Pollen Database (http://www.ngdc.noaa.gov/paleo/pollen.html). 


\section{Results}

\section{Cores TR-1D and TR-2D}

Cores TR-1D and TR-2D are $92 \mathrm{~cm}$ and $72 \mathrm{~cm}$ long, respectively, and each are strongly dominated (60-77\%) by Pinus pollen, with Quercus and Carya pollen subdominant (Figure 7.2). In TR-1D, Liquidambar abundance increased in the upper $20 \mathrm{~cm}$. Ambrosia is rare $(<1 \%)$ throughout both cores, as are pollen of other herbaceous taxa

\section{Core TR-5}

Core TR-5 is $95 \mathrm{~cm}$ long and is dominated by Pinus (28-59\%) and Quercus (11-31\%) pollen throughout (Figure 7.2). Carya and Liquidambar are present throughout the sequence, comprising $5-10 \%$ and $1-8 \%$ of the assemblages, respectively. Poaceae pollen abundance was greatest (4-20\%) in the uppermost $30 \mathrm{~cm}$. Ambrosia abundance increased in the upper $10 \mathrm{~cm}$, but even at that interval, its abundance was low $(<2.5 \%)$.

\section{Core PC-2B-3}

Core PC-2B-3 is $482 \mathrm{~cm}$ long and dominated by Pinus (36-75\%) and Quercus (23\%) pollen throughout (Figure 7.3). Ambrosia and Asteraceae pollen are common ( 5\% and 5-10\%, respectively) between $200 \mathrm{~cm}$ and $480 \mathrm{~cm}$. Above that point, both groups decrease in abundance, and Pinus pollen abundance increases, as does that of Liquidambar. Carya pollen also is present consistently in relatively low proportions $(<5 \%)$.

\section{Core PC-3B}

Core PC-3B is $162 \mathrm{~cm}$ long and dominated by Pinus (45-60\%) and Quercus (10-25\%) pollen (Figure 7.4). Carya and Liquidambar pollen also are common, comprising 5-10\% of the assemblage. There is a sharp decrease in Quercus pollen (from $25 \%$ to $15 \%$ ) and increase in 
Pinus pollen (45\% to $60 \%$ ) between $120 \mathrm{~cm}$ and $130 \mathrm{~cm}$ depth. Ambrosia is rare throughout the core, comprising $<5 \%$ of the assemblage.

\section{Core PC-4B}

Core PC-4B is $110 \mathrm{~cm}$ long and dominated by Pinus (20-50\%) and Quercus (20-30\%) pollen. Several distinctive stratigraphic intervals are noteworthy in this core. Between $70 \mathrm{~cm}$ and $110 \mathrm{~cm}, T s u g a$, TCT, and fern spores are exceptionally abundant (Figure 7.5). Poaceae pollen is abundant in that interval and in the overlying $20 \mathrm{~cm}$. From $30-40 \mathrm{~cm}$, pollen of Ambrosia and other Asteraceae reach their peak abundance, and Carya and Ulmus abundance increases, and in the upper from 0-20 cm, Pinus dominance of up to $60 \%$ abundance is reached, and Liquidambar abundance exceeded $10 \%$.

\section{Core PC-4C}

Core PC-4C is $92 \mathrm{~cm}$ long and dominated primarily by Quercus pollen (25-45\%), with Pinus pollen subdominant in all except the uppermost samples (15-43\%) (Figure 7.5). Between $20 \mathrm{~cm}$ and $90 \mathrm{~cm}$ depth, Nyssa pollen is an abundant (6-22\%) component of the assemblage, along with Liquidambar (4-14\%) and TCT (3-4\%). At $10 \mathrm{~cm}$ depth, Nyssa pollen virtually disappears from the assemblage, Liquidambar decreases by more than one-half, and Ambrosia, Asteraceae, and Pinus pollen each increase in abundance.

\section{PC-6B}

Core PC-6B is $480 \mathrm{~cm}$ long and is dominated by Pinus (46-76\%) and Quercus (7-25\%) throughout (Figure 7.6). Carya and Liquidambar also are present throughout the core, although Liquidambar increases in abundance beginning $\sim 250 \mathrm{~cm}$. Ambrosia was nearly absent at the base of the core but became a consistent component beginning at $\sim 340 \mathrm{~cm}$. 


\section{Discussion}

Using the increase in the relative abundance of Ambrosia and Pinus pollen to approximate post-Colonial times, we calculated minimum post-Colonial sedimentation rates for each of these Pocomoke Sound core sites. Two are particularly low $\left(0.1 \mathrm{~cm} \mathrm{yr}^{-1}\right)$ : (RV) TR-5 and PC-4C. (RV) TR-5 is located at the river mouth, and the agricultural horizon at $\sim 10 \mathrm{~cm}$ coincides with an unconformable oxidized surface apparently representing an erosion surface. In core PC-4C, there is an equally abrupt change from organic-rich silt-clay in the lower $70 \mathrm{~cm}$ of the core, representing an period when the area was vegetated by cypress-gum swamps, to coarse quartz pebbles in the upper $24 \mathrm{~cm}$, when the forests were logged and vegetation and sedimentation patterns changed. Site PC-4B also has fairly slow post-Colonial sedimentation rates of $0.4 \mathrm{~cm} \mathrm{yr}^{-1}$ and shows distinctive biostratigraphic zonation. The relatively high abundance of Poaceae and Tsuga pollen characteristic of the lower $40 \mathrm{~cm}$ is suggestive of an early Holocene or older age. The peak abundance of Ambrosia pollen around $40 \mathrm{~cm}$ corresponds to a sedimentological change from silty sand to unsorted clay-gravelly-silty sand, representing impacts of Colonial land clearance on the site. Further changes occurred by the mid- $20^{\text {th }}$ century $(\sim 20 \mathrm{~cm})$, with deposition of dark-gray silty clay and greater abundance of Liquidambar, suggesting further changes in the nearby vegetation.

The remaining cores all have post-Colonial sedimentation rates of $0.7->4.0 \mathrm{~cm} \mathrm{yr}^{-1}$. All pollen assemblages are dominated strongly (60-70\%) by Pinus pollen, and one biostratigraphic horizon is present in addition to the Ambrosia peak: the 1940-1950 Liquidambar increase. Liquidambar pollen doubles in abundance in the mid- $20^{\text {th }}$ century; because this windborne tree 
pollen is presented in Chesapeake Bay sediments even more consistently than Ambrosia pollen, this biostratigraphic marker is a particularly useful tool for dating geologically recent events.

\section{Conclusions}

Pollen assemblages from sediment cores in Pocomoke Sound document high sedimentation rates $(0.7->4.0 \mathrm{~cm}$ yr-1) at most sites throughout the Sound in post-Colonial time. At most sites, the entire sedimentary record recovered was post-Colonial, so little comparison may be made between pre- and post-Colonial vegetational composition in the region. At the river mouth (Core (RV) TR-5, oaks may have been logged from the general region, resulting in its reduced representation in the pollen record; little else may be gleaned from the pollen diagram. Prior to late $19^{\text {th }}$ to early $20^{\text {th }}$ century logging, the area surrounding the site PC-4C was a cypress-gum swamp; it subsequently was recolonized by pine and other early successional plants. The great abundance of Nyssa pollen in most of this core suggests a shoreline or very nearby source of sediment throughout much of the history of the site, because such great abundances of Nyssa pollen have been noted only in surface samples collected near the source plants (Willard and others, Chapter 3, this volume).

\section{Acknowledgements}

We gratefully thank Capt. Rick Younger and the crew of the R/V Kerhin for assistance in obtaining cores for use in this study. Tom Sheehan and Meredith Robertson assisted in sampling and laboratory preparation of samples. 


\section{References}

Bazzaz, F.A., 1974, Ecophysiology of Ambrosia artemisiifolia, a successional dominant: Ecology, v. 55, p. 112-119.

Brush, G.S., 1984, Patterns of recent sediment accumulation in Chesapeake Bay (VA, MD, U.S.A.) tributaries: Chemical Geology, v. 44, p. 227-242.

Cronin, T., Sanford, L., Langland, M., Willard, D., and Saenger, C., 2003, Estuarine sediment transport, deposition, and sedimentation, in Langland, M. and Cronin, T., eds., A summary report of sediment processes in Chesapeake Bayu and watershed: US Geological Survey Water-Resources Investigations Report, v. 03-4123, p. 61-79.

Defries, R.S., 1981, Effects of land-use history on sedimentation in the Potomac Estuary, Maryland: US Geological Survey Water-Supply Paper, v. 2234K, p. K1-K23.

Townsend, P.A., Brown, R.W., and Willard, D.A., 2003, Long-term geomorphic and vegetation change on the Roanoke River floodplain, North Carolina. Ecological Society of America, 88th Annual Meeting, Savannah, Georgia.

Traverse, A., 1988, Paleopalynology, Boston, Unwin-Hyman, 600 pp.

Willard, D.A., Cronin, T.M., Bernhardt, C.E., and Damon, J., 2004, Sediment transport in Pocomoke Sound, Maryland, inferred from microfossil in surface sediment. U. S. Geological Survey Open-file Report, this volume

Willard, D.A., Cronin, T.M., and Verardo, S., 2003, Late Holocene climate and ecosystem variability from Chesapeake Bay sediment cores: The Holocene, v. 13, p. 201-214. 


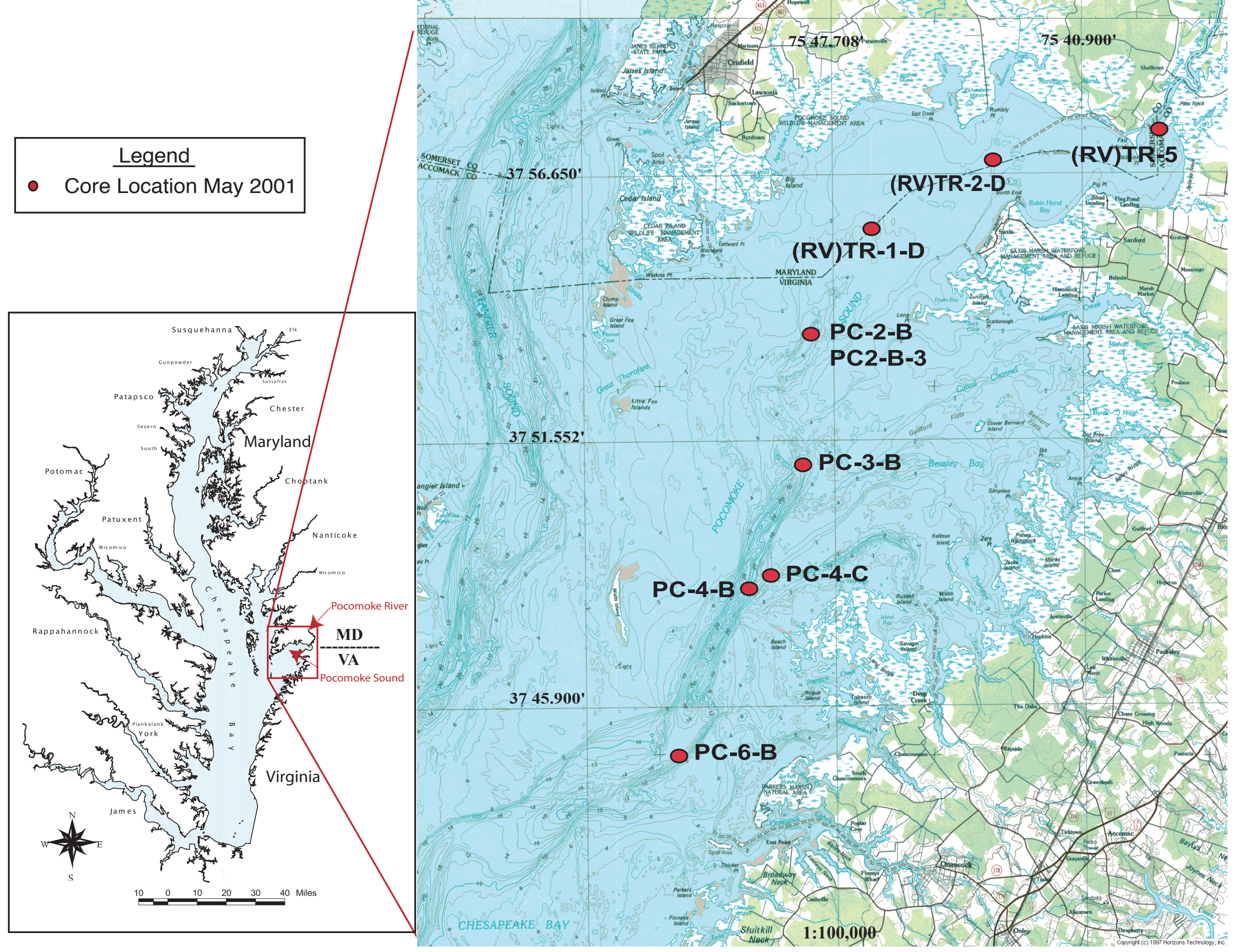

Figure 7.1. Location of cores collected in Pocomoke Sound, Maryland. 


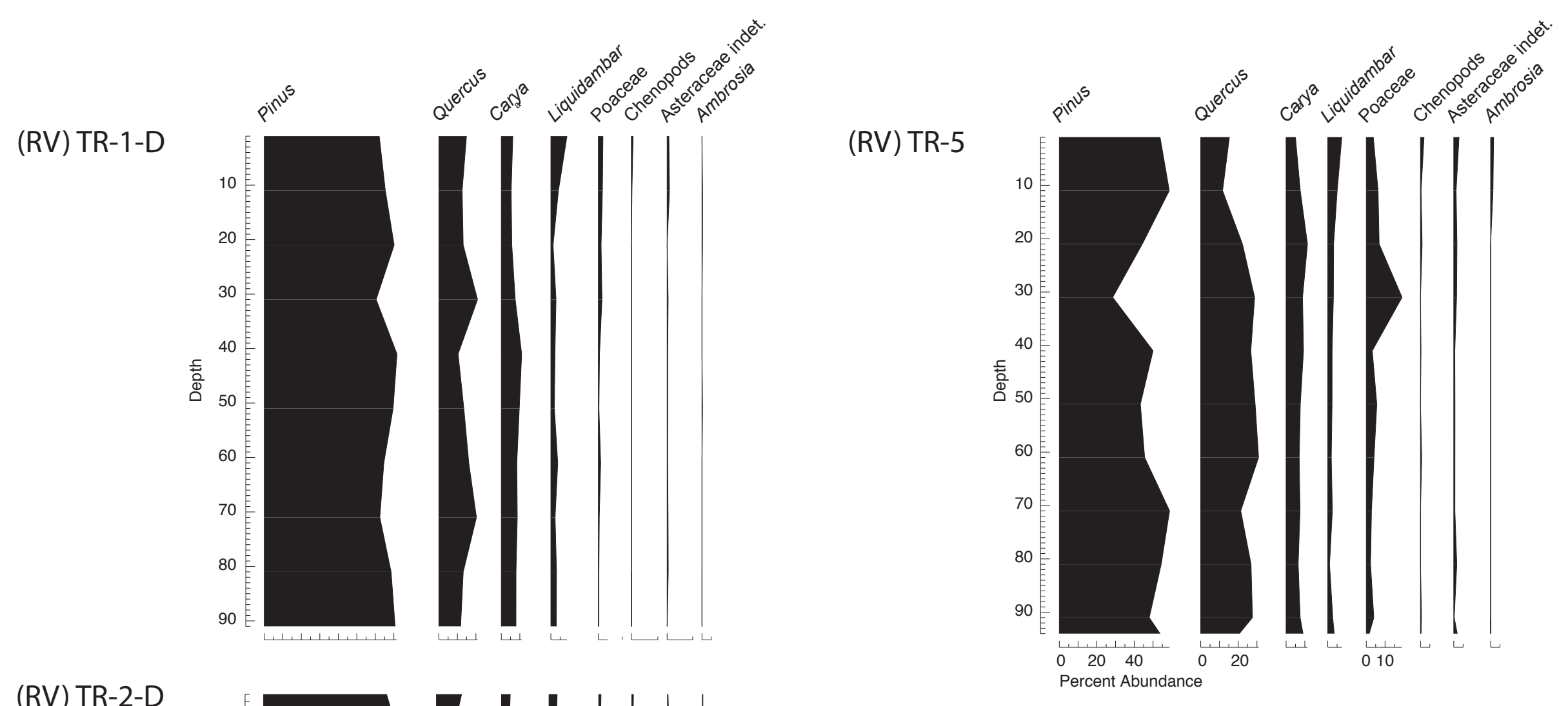

(RV) TR-2-D

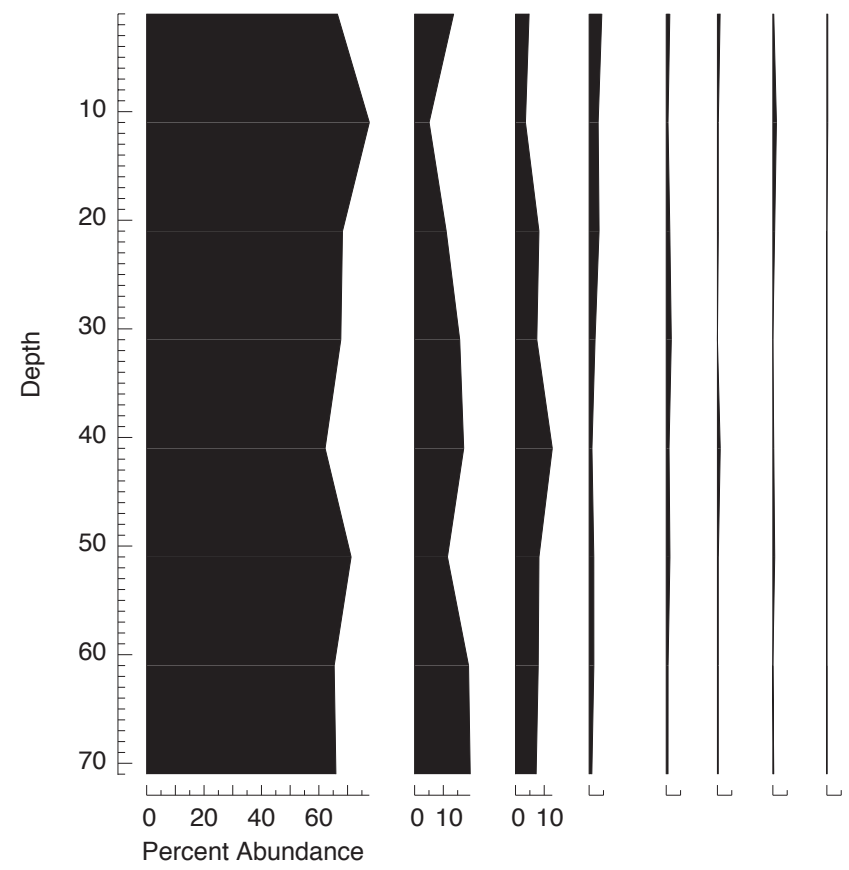

Figure 7.2. Percent abundance of pollen of major plant taxa, cores (RV) TR-1-D, TR-2-D, and TR-5, Pocomoke Sound, Maryland. 


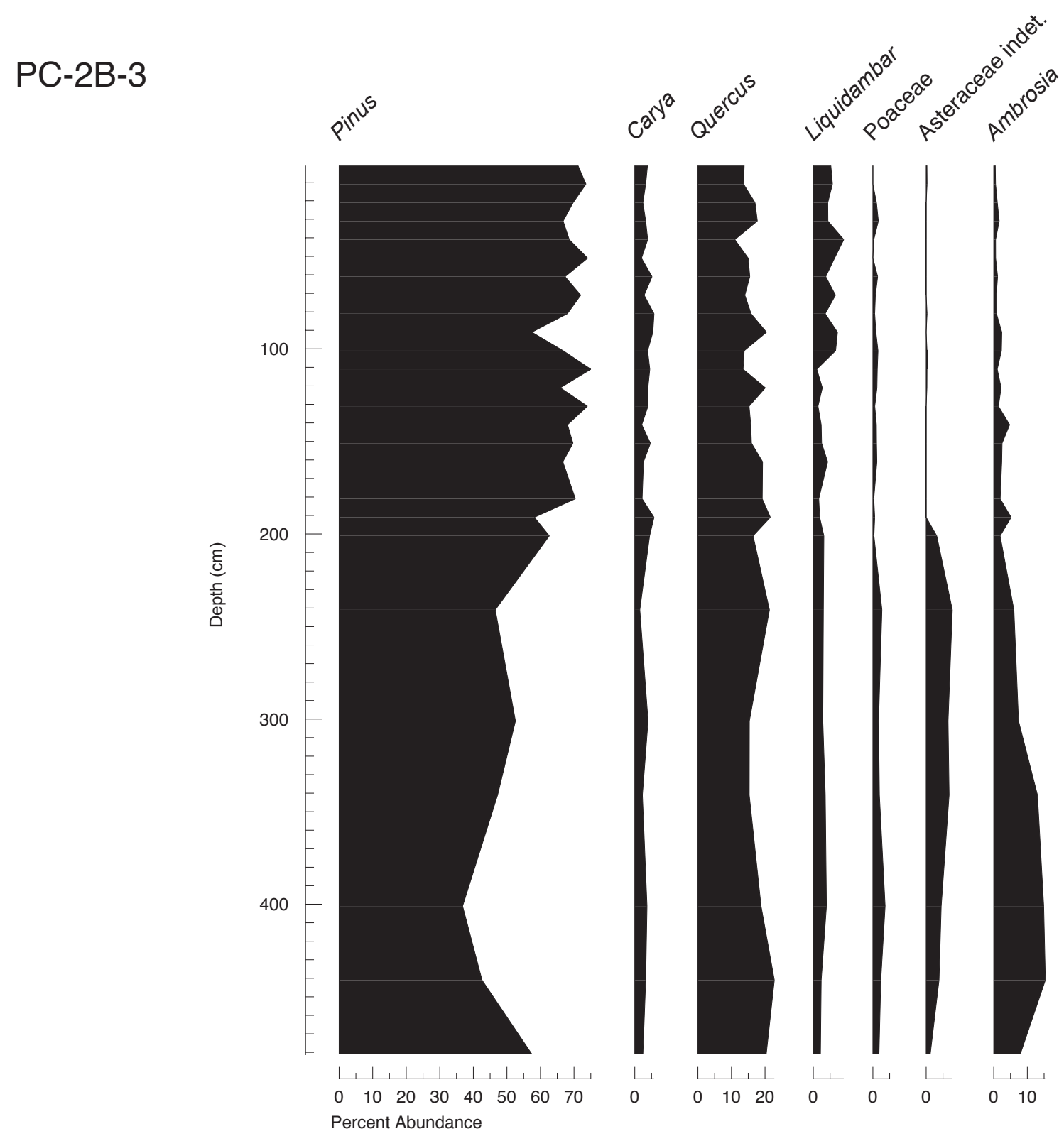

Figure 7.3. Percent abundance of pollen of major plant groups in cores PC2B and PC2B3, Pocomoke Sound, Maryland. 
PC3B

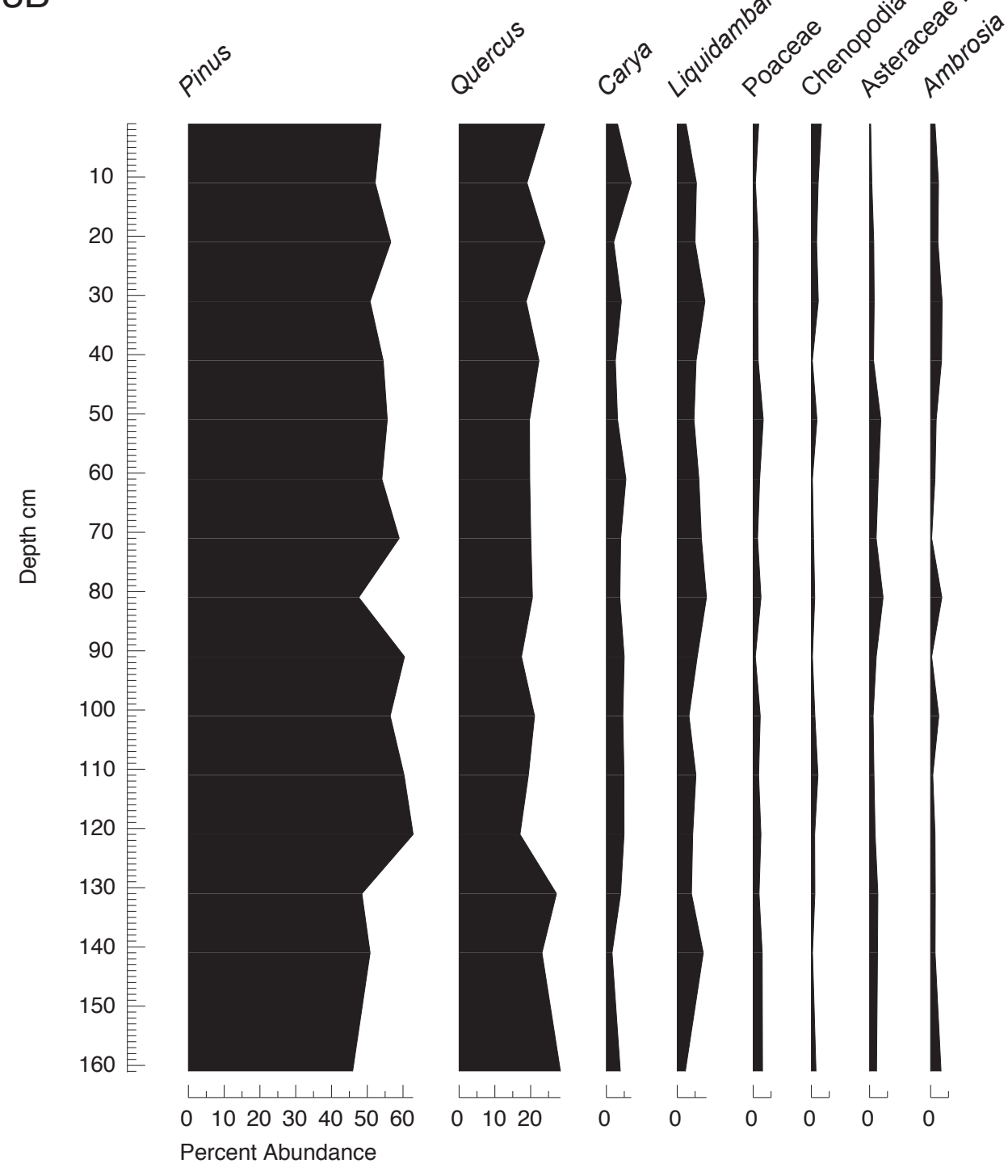

Figure 7.4. Percent abundance of pollen of major plant taxa, core PC3B, Pocomoke Sound, Maryland. 

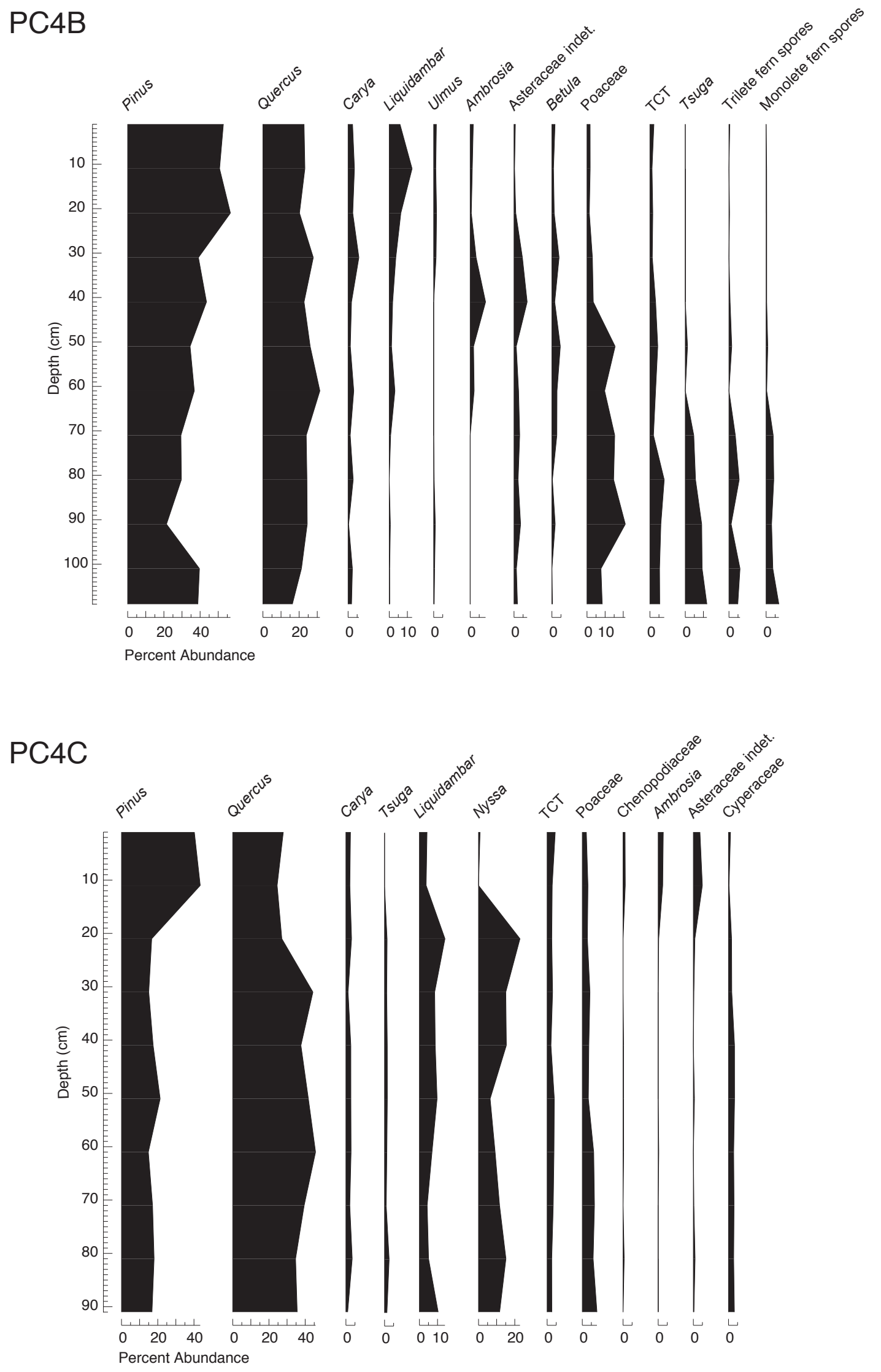

Figure 7.5. Percent abundance of pollen of major plant taxa, cores PC4B and PC4C, Pocomoke Sound, Maryland. 


\section{PC6B}

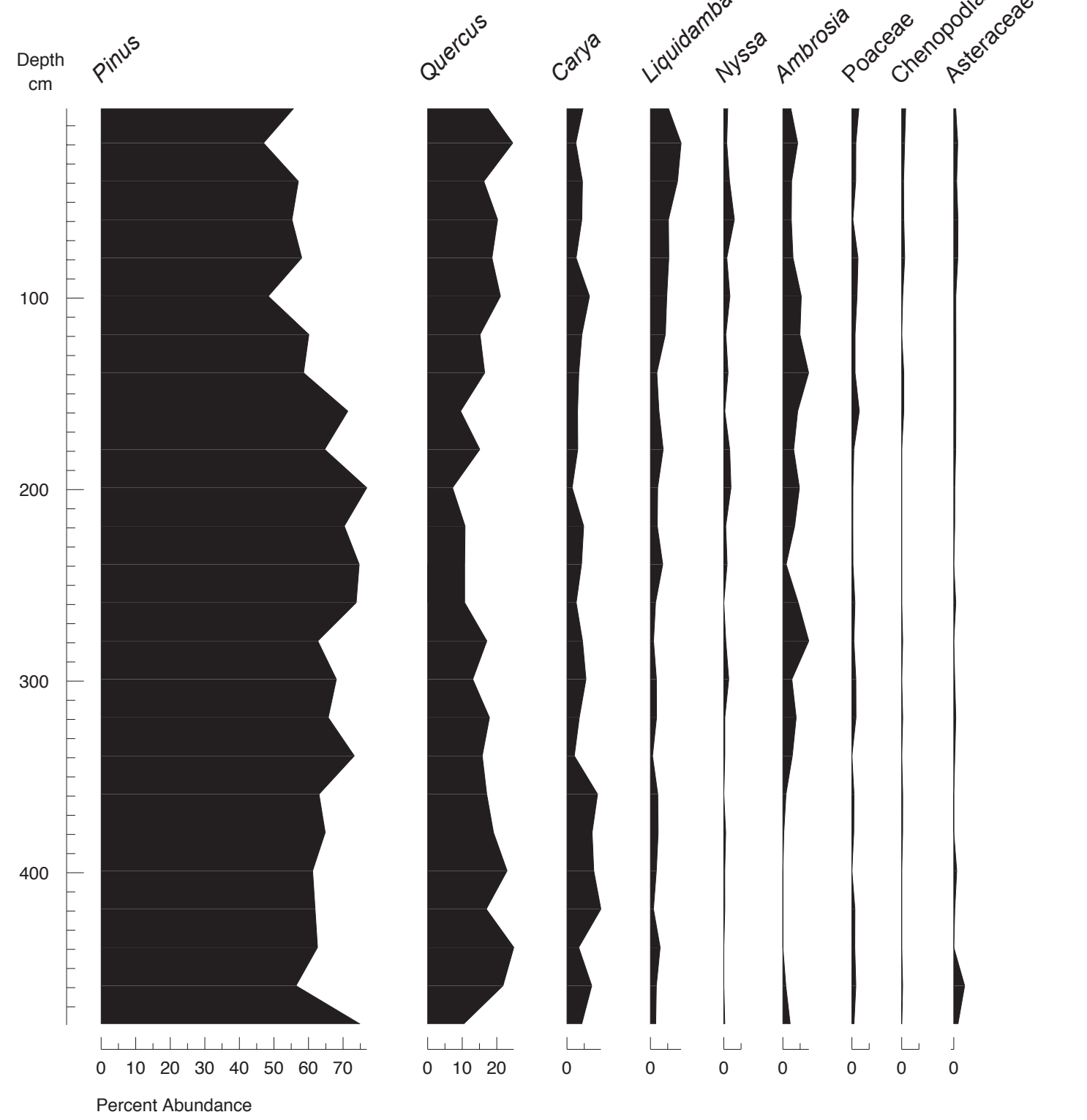

Figure 7.6. Percent abundance of pollen of major plants in core PC6B, Pocomoke Sound, Maryland. 
Table 7.1. Location of Cores in Pocomoke Sound

\begin{tabular}{ccccc} 
Core & Date Taken & Lat $(\mathbf{N})$ & Long $(\mathbf{W})$ & Water Depth $(\mathbf{m})$ \\
\hline (RV)TR-5 & $16 / 5 / 01$ & $37^{\circ} 57.086^{\prime}$ & $76^{\circ} 38.880^{\prime}$ & 1.9 \\
(RV)TR-1-D & $15 / 5 / 01$ & $37^{\circ} 55.766^{\prime}$ & $75^{\circ} 46.868^{\prime}$ & 3.8 \\
(RV)TR-2-D & $16 / 5 / 01$ & $37^{\circ} 57.037^{\prime}$ & $75^{\circ} 43.516^{\prime}$ & 3.4 \\
PC2B & $15 / 5 / 01$ & $37^{\circ} 53.429^{\prime}$ & $75^{\circ} 48.408^{\prime}$ & 7.9 \\
PC3B & $15 / 5 / 01$ & $37^{\circ} 50.741^{\prime}$ & $75^{\circ} 48.745^{\prime}$ & 11.4 \\
PC4B & $15 / 5 / 01$ & $37^{\circ} 48.300^{\prime}$ & $75^{\circ} 50.301^{\prime}$ & 27.3 \\
PC4C & $15 / 5 / 01$ & $37^{\circ} 48.496^{\prime}$ & $75^{\circ} 49.820^{\prime}$ & 7.3 \\
PC6B & $15 / 5 / 01$ & $37^{\circ} 44.910^{\prime}$ & $75^{\circ} 52.334^{\prime}$ & 14.6
\end{tabular}

